\title{
FLORA DA SERRA DO CIPÓ, MINAS GERAIS: RUBIACEAE
}

\author{
DANIELA C. ZAPPI*, MARIA FERNANDA CALIÓ** \& JOSÉ RUBENS PIRANI**
}

\author{
*HLAA, Royal Botanic Gardens, Kew, Richmond, Surrey, TW9 3AE, United Kingdom/ Gardens by the Bay, Singapore \\ d.zappi@kew.org \\ ${ }^{* *}$ Departamento de Botânica, Instituto de Biociências, Universidade de São Paulo. Rua do Matão, 277, 05508-090 -
} São Paulo, SP, Brasil, mfecalio@gmail.com; pirani@usp.br

\begin{abstract}
Flora of Serra do Cipó, Minas Gerais: Rubiaceae). The study of the family Rubiaceae is part of the project "Flora of Serra do Cipó, Minas Gerais, Brazil". In that area, the family is represented by 36 genera, with 91 species. A new species of Psyllocarpus is described and illustrated. Key to the species, descriptions and illustrations, as well as comments on the geographic distribution and habitats of the species are presented.
\end{abstract}

Key words: Brazil, Campos Rupestres, floristics, Psyllocarpus.

Resumo - (Flora da Serra do Cipó, Minas Gerais: Rubiaceae). O estudo da família Rubiaceae é parte do levantamento da "Flora da Serra do Cipó, Minas Gerais, Brasil". Esta família é representada na área por 36 gêneros, totalizando 91 espécies. Uma nova espécie de Psyllocarpus é descrita e ilustrada. São apresentadas chave para gêneros e espécies, descrições e ilustrações, além de comentários sobre a distribuição geográfica e hábitat das espécies.

Palavras-chave: Brasil, Campos Rupestres, floristics, Psyllocarpus.

RUBIACEAE JUSS.

Árvores, arbustos, subarbustos, ervas ou lianas; ramos glabros ou pilosos, inermes ou armados, cilíndricos, aplanados ou tetragonais, às vezes alados; plantas monoicas ou dioicas. Estípulas interpeciolares, raramente intrapeciolares (Hillia), inteiras, bilobadas ou fimbriadas, persistentes ou caducas, geralmente com coléteres na face interna. Folhas simples, opostas, decussadas ou verticiladas, glabras ou pilosas, com lâmina ampla ou reduzida, margem inteira. Inflorescência terminal ou axilar; cimosa a racemosa, paniculada, capitada ou espiciforme, raramente flores solitárias. Flores bissexuadas ou, menos frequentemente, unissexuadas, actinomorfas ou raramente zigomorfas, diclamídeas, às vezes monoclamídeas (Galium), 4-5(-6-7)-meras; distilia presente ou não, às vezes com apresentação secundária do pólen (Genipa); corola gamopétala, prefloração valvar, imbricada ou contorcida; androceu isostêmone, estames alternipétalos, epipétalos, exsertos ou inclusos, anteras rimosas; ovário ínfero, 25-locular (raramente 1-locular), lóculos 1 a pluriovulados; estigma bífido ou capitado; disco nectarífero localizado acima do ovário. Frutos do tipo baga, drupa ou cápsula, deiscente ou indeiscente.
Posicionada entre as cinco maiores famílias de Angiospermas, Rubiaceae conta com 125 gêneros e 1.395 espécies registradas no Brasil (Barbosa et al. 2014). Em termos de Domínios Fitogeográficos, existem listas florísticas da Mata Atlântica (Zappi et al. 2009) e da Caatinga (Zappi \& Nunes 2002). Na Amazônia, sabe-se que a família é extremamente expressiva em número de gêneros e espécies, mas apenas estudos pontuais foram realizados (Delprete \& Cortés-B. 2006, Taylor et al. 2007, Zappi et al. 2011), não permitindo análises mais completas a respeito da distribuição e abundância das espécies. Estudos florísticos e floras de campos rupestres (Zappi \& Stannard 1995, Campos et al. 2006) evidenciam a importância da família nos ambientes campestres e também apontam para interessantes endemismos em um número relativamente pequeno de gêneros, por exemplo Hindsia (di Maio 1997), Declieuxia (Kirkbride 1976) e Perama (Steyermark \& Kirkbride 1977).

Bibliografia básica: Andersson (1992), Barbosa et al. (2010), Cabral (1991, 1996), Cabral \& Bacigalupo (1997 a, b, 2000), Campos et al. (2006), Delprete et al. (2005), Jung-Mendaçolli (2007), Kirkbride (1976), Müller Argoviensis (1881), Schumann (1888, 1889), Steyermark (1972), Steyermark \& Kirkbride (1977), Zappi \& Stannard (1995). 
1. Trepadeiras herbáceas com caule volúvel.

2. Corola vermelha, 4.5-6 cm compr.; flores em dicásios

21. Manettia

2 '. Corola alva a alvo-esverdeada, $1 \mathrm{~mm}$ compr.; flores em umbelas reunidas em panículas

1'. Plantas eretas ou prostradas, às vezes escandentes, mas com caule não volúvel.

3. Ervas a subarbustos; flores tetrâmeras.

4. Frutos suculentos.

5. Frutos alvos, subtendidos por 4 brácteas, ovário 2-ovulado

5'. Frutos azuis a violáceos, não subtendidos por brácteas, ovário pluriovulado .......

16. Galium

4'. Frutos capsulares, esquizocárpicos ou não suculentos.

6. Frutos globosos a turbinados, não complanados.

7. Tubo da corola geralmente revestido por tricomas estrigosos, seríceos ou vilosos; ovário trilocular

7'. Tubo da corola glabro ou ligeiramente piloso; ovário bilocular.

8. Frutos esquizocárpicos, divididos em mericarpos

26. Perama

8 '. Frutos capsulares deiscentes.

9. Lóculos do ovário multiovulados

12. Diodella

9'. Lóculos do ovário uniovulados.

10. Inflorescências em cimeiras expandidas

24. Oldenlandia

10'. Inflorescências em glomérulos compactos

15. Galianthe

6 '. Frutos aplanados ou complanados.

11. Folhas aciculares a lineares; frutos ovais, complanados, com septo paralelo às valvas

4. Borreria

11 . Folhas com formas variadas; frutos parecendo cordiformes, aplanados, formados por dois mericarpos, com septo perpendicular às valvas

29. Psyllocarpus o a árvores; flores geralmente pentâmeras ou hexâmeras.

12. Inflorescências axilares ou subterminais.

13. Estípulas bipartidas

11. Declieuxia

13'. Estípulas inteiras.

14. Folhas reduzidas, aciculares ou lineares

14'. Folhas com lâmina desenvolvida.

15. Infloresências sésseis, protegidas por brácteas; bagas multisseminadas

15'. Inflorescências pedunculadas, brácteas ausentes ou pouco desenvolvidas; cápsulas

ou drupas.

16. Folhas verticiladas.

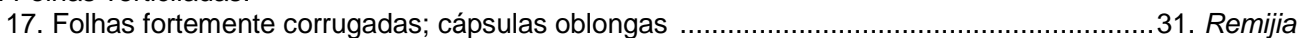

17 . Folhas planas; cápsulas globosas 35. Simira

16 '. Folhas opostas.

18. Nervuras terciárias inconspícuas a pouco conspícuas; inflorescências racemosas ou paniculadas, multifloras; corola infundibuliforme

5. Chiococca

18'. Nevuras terciárias geralmente distintas, paralelas; inflorescências cimosas, dicasiais, 2-12-floras; corola tubulosa ou hipocrateriforme

19. Pecíolos 1-8 mm compr.; corola até $10 \mathrm{~mm}$ compr.; frutos estreitamente elipsoides a cilíndricos

19'. Pecíolos 15-50 mm compr.; corola 30-45 mm compr.; frutos globosos a subglobosos

6. Chomelia

12'. Inflorescências sempre terminais ou flores terminais.
20. Prefloração da corola contorcida ou imbricada; frutos com mais de uma semente por lóculo.

20. Prefloração da corola contorcida ou imbricada; frutos com
21. Plantas armadas, ramos com 2-4 espinhos apicais

21'. Plantas inermes.

22. Corola vermelha

2. Augusta

22'. Corola alva, amarelada, creme, rosada ou vinácea.

23. Plantas dioicas; flores unissexuadas; frutos bacáceos.

24. Flores com apresentação secundária do pólen; frutos com mais de $5 \mathrm{~cm}$ compr.

17. Genipa

24'. Pólen apresentado diretamente pelas anteras; frutos com menos de $3 \mathrm{~cm}$ compr.

25. Arbustos ou raramente arvoretas; folhas geralmente opostas, elípticas, obovais ou ovais; tubo do cálice truncado; frutos globosos

8. Cordiera

25'. Árvores; folhas geralmente verticiladas, lanceoladas a elípticas; tubo do cálice laciniado ou denteado; frutos ovoides a elipsoides

23'. Plantas monoicas; flores bissexuadas; frutos capsulares (exceto Posoqueria e Tocoyena).

26. Inflorescências paniculadas amplas, multifloras; flores até $1 \mathrm{~cm}$ compr., frutos até $5 \mathrm{~mm}$ compr.

27. Ramos quadrangulares; frutos turbinados a obovoides

3. Bathysa

27'. Ramos cilíndricos; frutos globosos a bi-globosos.

28. Folhas $5-8(-10) \mathrm{cm}$ compr.; estípulas livres ...........
28 '. Folhas $20-35(-40) \mathrm{cm}$ compr.; estípulas conatas

23. Molopanthera

34. Schizocalyx 
Flora da Serra do Cipó, Minas Gerais: Rubiaceae

26'. Inflorescências dicasiais compactas, 2-15-floras; flores maiores do que $4 \mathrm{~cm}$ compr., solitárias ou em frutos com mais de $1 \mathrm{~cm}$ compr.

29. Flores hexâmeras; frutos capsulares.

30. Flores actinomorfas; corola tubulosa com tubo longo e estreito; folhas sem domácias; sementes comosas

30 '. Flores zigomorfas; corola campanulada, tubo relativamente amplo; folhas com domácias; sementes aladas

19. Hillia

folhas com domácias
'. Flores pentâmeras; frutos bacáceos.

31. Plantas glabras; corola com prefloração imbricada

10. Coutarea

31'. Plantas pilosas, especialmente as folhas e corola; corola com

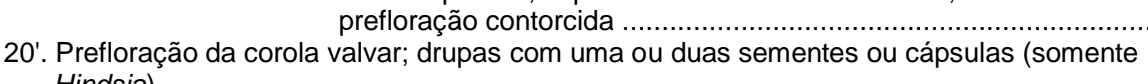

27. Posoqueria

Hindsia).

32. Corola 4,5-6,5 cm compr.; frutos multisseminados; sementes discoides, aladas;

36. Tocoyena

32'. Corola até $2 \mathrm{~cm}$ compr.; frutos 1-2-seminados; sementes não-aladas.

33. Estípulas geralmente inteiras, espatuladas, triangulares, agudas, 1-aristadas ou

múticas.

34. Flores azuis a violáceas; estípulas aristadas

34'. Flores alvas; estípulas não aristadas.

35. Estípulas espatuladas

35 . Estípulas truncadas ou múticas.

36. Futos biloculares com duas sementes; folhas sem domácias 28.Psychotria (P. carthagenensis)

36'. Frutos uniloculares com apenas uma semente; folhas com domácias

22. Margaritopsis

33'. Estípulas bífidas, bilobadas, franjadas ou com vários dentes ou apêndices aristados

ou espinescentes.

37. Flores zigomorfas com tubo alargado basalmente; ramos da inflorescências

amarelos, alaranjados ou vináceos.....

25. Palicourea

37'. Flores actinomorfas com tubo não alargado basalmente; ramos da inflorescência

verdes ou alvos, às vezes ligeiramente arroxeados.

38. Frutos parecendo cordiformes, aplanados, formado por dois mericarpos, com septo perpendicular às valvas; plantas campestres ....

11. Declieuxia

38 '. Frutos suculentos, esféricos, obovoides, ovoides ou subcilíndricos, com 2

pirênios hemisféricos; plantas apêndices aristados ou espinescentes florestais.

39. Estípulas inteiras com.

32. Rudgea

39'. Estípulas bífidas ou bipartidas

28. Psychotria

\section{Amaioua Aubl.}

Árvores; ramos angulosos, apresentando ramificação bifurcada, com entrenós de extensão distintos. Estípulas inteiras, estreitamente obovais a triangulares, seríceas, prematuramente decíduas. Folhas opostas ou geralmente verticiladas, pecioladas. Flores unissexuadas (em plantas dioicas), actinomorfas, 6-8-meras, em inflorescências terminais; hipanto hemigloboso a turbinado, tubo desenvolvido, laciniado a denteado; corola com prefloração contorcida, tubulosa até duas vezes mais longa que o cálice; ovário 2 locular. Bagas com pericarpo coriáceo, flexível; sementes reniformes.

1.1. Amaioua intermedia Mart. ex Schult. \& Schult.f. in J.J.Roemer \& J.A.Schultes, Syst. Veg. 7: 90. 1829.

Fig. 1. A-B.

Árvores 5-8 $\mathrm{m}$ alt., entrenós até $8 \mathrm{~cm}$ compr., entrenós reprodutivos até $1 \mathrm{~cm}$ compr., ramos com casca castanho-acinzentada desprendendo-se em faixas ou escamas, râmulos seríceos. Estípulas estreitamente obovais quando expandidas, $15-25 \mathrm{~mm}$ compr., $8 \mathrm{~mm}$ larg., geralmente involutas e retorcidas no ápice, externamente seríceas, decíduas. Folhas opostas ou geralmente verticiladas, pecioladas; pecíolo 10-15 $\mathrm{mm}$ compr.; lâmina lanceolada a elíptica, base aguda a cuneada, margem plana, ápice agudo a acuminado, (5-)7-15 cm compr., 2-6 cm larg., cartácea, discolor, face adaxial secando castanha a castanho-oliváceo escura, glabrescente a glabra, face abaxial secando castanho-clara, amarelada ou olivácea, esparsamente pilosa, domácias ocasionalmente formadas por tufos de tricomas na axila das nervuras; venação broquidódroma ou eucamptódroma, nervuras na face abaxial salientes e hirsutas, na face adaxial pilosas. Botões florais agudos, rosados, tubo da corola externamente seríceo; flores masculinas em conjuntos de dicásios pedunculados paucifloros (3-7 flores); flores 6-7meras; hipanto 5-6 mm compr., tubo laciniado, lacínios recurvos, $1 \mathrm{~mm}$ compr.; corola $10 \mathrm{~mm}$ compr., alva, tubulosa, lobos patentes a sub-reflexos, ca. $5 \mathrm{~mm}$ compr., estames inclusos, anteras ca. $5 \mathrm{~mm}$ compr., estilete pouco evidente, incluso, $5 \mathrm{~mm}$ compr.; flores femininas pediceladas, em conjuntos de $3-5$. Bagas até $18 \mathrm{~mm}$ compr., $8 \mathrm{~mm}$ larg., ovoides a elipsoides, pedunculadas; pericarpo seríceo, verde-vináceo quando maduro; sementes 6-10, reniformes, aplanadas, 3-4 mm compr. 


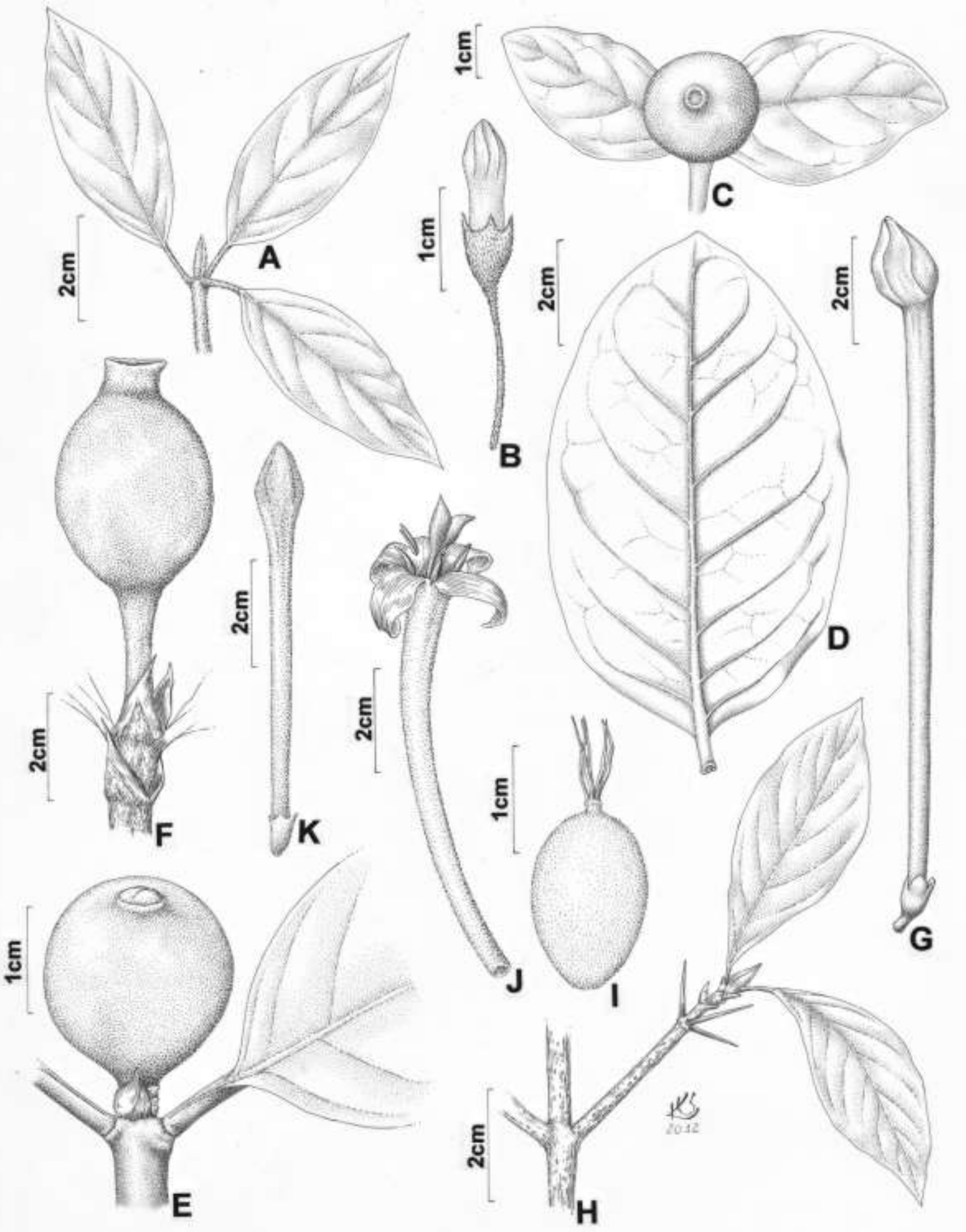

Fig. 1 - Arbustos a árvores, frutos bacáceos multisseminados, tribo Gardenieae. A-B. Amaioua intermedia. A. Ápice do ramo vegetativo. B. Botão floral. C. Cordiera concolor, Fruto. D. Cordiera elliptica, Folha. E. Cordiera sessilis, Fruto. F. Genipa americana, Fruto em desenvolvimento. G. Posoqueria latifolia, Botão floral. H-I. Randia armata. H. Detalhe do ramo vegetativo. I. Fruto. J-K. Tocoyena formosa. J. Corola aberta. K. Botão floral. (A-B: Zappi 2492. C: Zappi 2650. D: Zappi 2218. E: Zappi 2656. F: Zappi 2406. G: CFCR 6376. H: Martins 94. I: Milliken 4122. J-K: Zappi 2456). 
Material examinado: Congonhas do Norte, estrada para Costa Senna, 1845'04"S, 4340'43"W, J.R. Pirani et al. 4086, 1.III.1998, fr. (SPF). Itambé do Mato Dentro, Santana do Rio Preto (Cabeça de Boi), APA do Parque Nacional da Serra do Cipó, 1923'46.9"S, 4324'07.4"W, M.F. Santos \& H. Serafim 323, 16.III.2008, fr. (BHCB, SPF); M.F. Santos \& H. Serafim 459, 17.III.2008, fr. (K, SPF). Santana de Pirapama, Serra do Cipó, acesso pela Faz. Inhame, Trilha da Serra

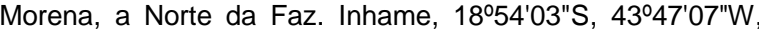
D.C. Zappi et al. 2065, 12.III.2009, fr. (K, RB, SPF); Capela de São José, Trilha da Senhorinha, caminho a Congonhas do Norte, 1857'4,5"S, 4343'46,7"W, D.C. Zappi et al. 2492 , 25.XI.2009, fl. (K, RB, SPF). Santana do Riacho, km 116 ao longo da rodovia Belo Horizonte - Conceição do Mato Dentro, estrada da Usina, G.M. Barroso CFSC 7256, 19.IV.1981, fl. (SPF); idem, km 133 ao longo da rodovia Belo Horizonte Conceição do Mato Dentro, estrada da Usina, N.L. Menezes et al. CFSC 7109, fr. (F, K, SPF); Estrada da Usina, M.C. Henrique et al. CFSC 6889, 9.I.1981, fl. (SP, SPF); idem, A.B. Joly et al. CFSC 1761, 16.IV.1972, fr. (UEC); Usina Vau de Lagoa, J. Semir \& A.B. Martins 13449 [UEC 29956], 6.III.1982, fr. (UEC).

Material adicional: Minas Gerais: São Thomé das Letras, R. Mello-Silva et al. CFCR 5724, 30.X.1984, fl. (SPF).

Amaioua intermedia ocorre do Peru ao Brasil, concentrando-se nos estados do Paraná, São Paulo, Minas Gerais, Goiás, Distrito Federal e Mato Grosso. $\mathrm{Na}$ Serra do Cipó, foi observada em matas ciliares e capões de mata, com flores em novembro e frutificando em março e abril.

\section{Augusta Pohl}

Arbustos glabros, eretos; ramos cilíndricos, apresentando ramificação bifurcada ou unilateral, com entrenós de extensão distintos. Estípulas terminais, inteiras, conatas, triangulares, decíduas. Folhas opostas, pecioladas. Flores bissexuadas, actinomorfas, 5-meras, em inflorescências terminais hipanto turbinado, com tubo curto, alargado, laciniado a denteado; corola com prefloração contorcida, tubulosa, muito mais longa que o cálice, ovário 2 locular. Cápsula bivalvar, septicida e loculicida, com endocarpo flexível; sementes numerosas, tetraédricas.

2.1. Augusta Iongifolia (Spreng.) Rehder, Kew Bull. 1935: 364. 1935.

Fig. 2. A-B.

Arbustos eretos, totalmente glabros, entrenós até $4 \mathrm{~cm}$ compr., ramos cilíndricos com casca castanho-enegrecida estriada, râmulos mais claros. Estípulas triangulares, agudas,1,5-2 mm compr., $3 \mathrm{~mm}$ larg., decíduas. Folhas opostas, pecioladas; pecíolo 20-45 mm compr.; lâmina lanceolada, base aguda a decorrente, margem espessada a revoluta, ápice agudo, (3-)6-10 cm compr., (0,5-)0,8-2(-2,5) cm larg., cartácea, discolor, face adaxial secando castanha a enegrecida, abaxial secando castanho-clara, amarelada ou olivácea, esparsamente pilosa, domácias ausentes; nervuras inconspícuas em ambas as faces. Cimeiras curtamente pedunculadas, com (36-9 flores; botões florais agudos; hipanto $8-10 \mathrm{~mm}$ compr., tubo do cálice curto e alargado, laciniado, lacínios agudos, 1,5-3 mm compr.; corola 5-6 cm compr., vermelha; tubulosa, lobos ereto-patentes, ca. 6-8 mm compr., estames exsertos, anteras ca. $6 \mathrm{~mm}$ compr., estilete exserto, 50-55 mm compr., estigma bilobado com ramos alargados. Cápsulas $15 \mathrm{~mm}$ compr., obovoides, pedunculadas, epicarpo subcoriáceo, endocarpo flexível, rompendo-se quando maduro; sementes inúmeras por fruto, tetraédricas, 0,5 $\mathrm{mm}$ compr., amareladas.

Material examinado: Jaboticatubas, Serra do Cipó, W. Mantovani 76, 26.VI. 1979, fl., fr. (SP); trilha para Cachoeira da Farofa, próximo à sede do IBAMA, 1922'26"S, 4335'52,9"W, M. Groppo et al. 1469, 22.IX.2007, fl. (SPF, SPFR); Parque Nacional da Serra do Cipó, subida para a Serra das Bandeirinhas, por cima do Canyon do Córrego dos Mascates, M.T.V.A. Campos et al. CFSC 12973, 8.IX.1992, fl., fr. (SPF); rodovia Lagoa Santa - Conceição do Mato Dentro - Diamantina, km 117, A.B. Joly \& J. Semir CFSC 3674, 4.XI.1972, fl. (UEC); idem, M.G.L. Wanderley 507, 3.XI.1978, fl., fr. (SP); idem, J. Semir \& M. Sazima CFSC 3316, 3.IX.1972, fl., fr (SP); idem, J. Semir et al. CFSC 4388, 4.IX.1973, fl. (SP); idem, km 118, A. Furlan 6132, 24.V.1980, fl. (SP). Santana de Pirapama, Serra do Cipó (Serra da Lapa), estrada Santana do Riacho - Santana de Pirapama, trecho de São José da Cachoeira - Inhame, Cachoeira Bonita, 18584'0"S, 434635"W, V.C. Souza et al. 32634, 18.II.2007, fl., fr. (ESA, K, SPF); Vilarejo Inhame, Cachoeira Inhame, 1856'39"S, 4347'12"W, L.M. Borges et al. 212, 17.XI.2007, fl., fr. (K, RB, SPF); acesso por Inhame, Trilha do João Carrinho, 193'5,4"S, 4344'29,6"W, D.C. Zappi et al. 2637, 28.XI.2009, fl., fr. (K, RB, SPF). Santana do Riacho, Serra do Cipó, A.M. Giulietti et al. CFSC 5699, 16.VIII.1979, fl., fr (SP); proximidades do rio Cipó, F. Barros 1355, 3.II.1987, fl., fr. (SP); rio próximo à Usina, ao longo da rodovia Belo Horizonte - Conceição do Mato Dentro, V.C. Souza \& R. Simão CFSC 10092, 7.V.1987, fl., fr. (SPF); Estrada da Usina, T.M. Cerati et al. 114, 8.l. 1984, fl., fr. (SP); km 107, caminho para a Usina Dr. Pacífico Mascarenhas, E. Forero et al. 7942 [CFSC 8855], 7.IX.1980, fl. (SPF); km 117 ao longo da rodovia Belo Horizonte - Conceição do Mato Dentro, T.B. Cavalcanti et al. CFSC 9726, 4.V.1986, fl., fr. (SPF); km 126/127, N.L. Menezes CFSC 7103, 1.III.1981, fl., fr. (F, K, MBM, RB, SPF); Parque Nacional da Serra do Cipó, trilha da Cachoeira da Farora, C.S. Sato et al. 2, 9.X.2004, fl. (SPF); idem, C.S. Sato \& C.A. Garcia 58, 3.II.2006, fl., fr. (SPF); trilha da Sede do Ibama, J.P. Cometti et al. 3, 24.IX.1999, fl., fr. (SPF); Lagoa Comprida, Cachoeira da Farofa, T.B. Cavalcanti et al. CFSC 10613, 7.IX.1987, fl., fr. (F, SP, SPF); 1922'49"S, 4334'37"W, V.C. Souza et al. 25234, 6.VII.2001, fl., fr. (ESA, SPF); trilha do Córrego Gavião para Bandeirinha, R.C. Forzza et al. 307, 20.X.1997, fl., fr. (K, SPF); Vale do Córrego Andrequicé (Indequicé), A. Furlan et al. CFSC 6738, 8.XI.1980, fl. (SP, SPF); Fazenda Serra do Cipó, L.R. Lima et al. 130, 23.VIII.2000, fl., fr. (SPF); Cardeal Mota, Faz. Monjolos, caminho para cachoeiras Gavião e Farofa, 1920'35"S, 4335'15"W, K. Yamamoto et al. C-168, 26.IX.2002, fl. (UEC).

Espécie amplamente distribuída no Brasil, acompanha cursos d'água desde o Planalto Central até a região litorânea, crescendo muitas vezes parcialmente imersa. Na Serra do Cipó, ocorre entre rochas, com as raízes imersas na água de córregos, 


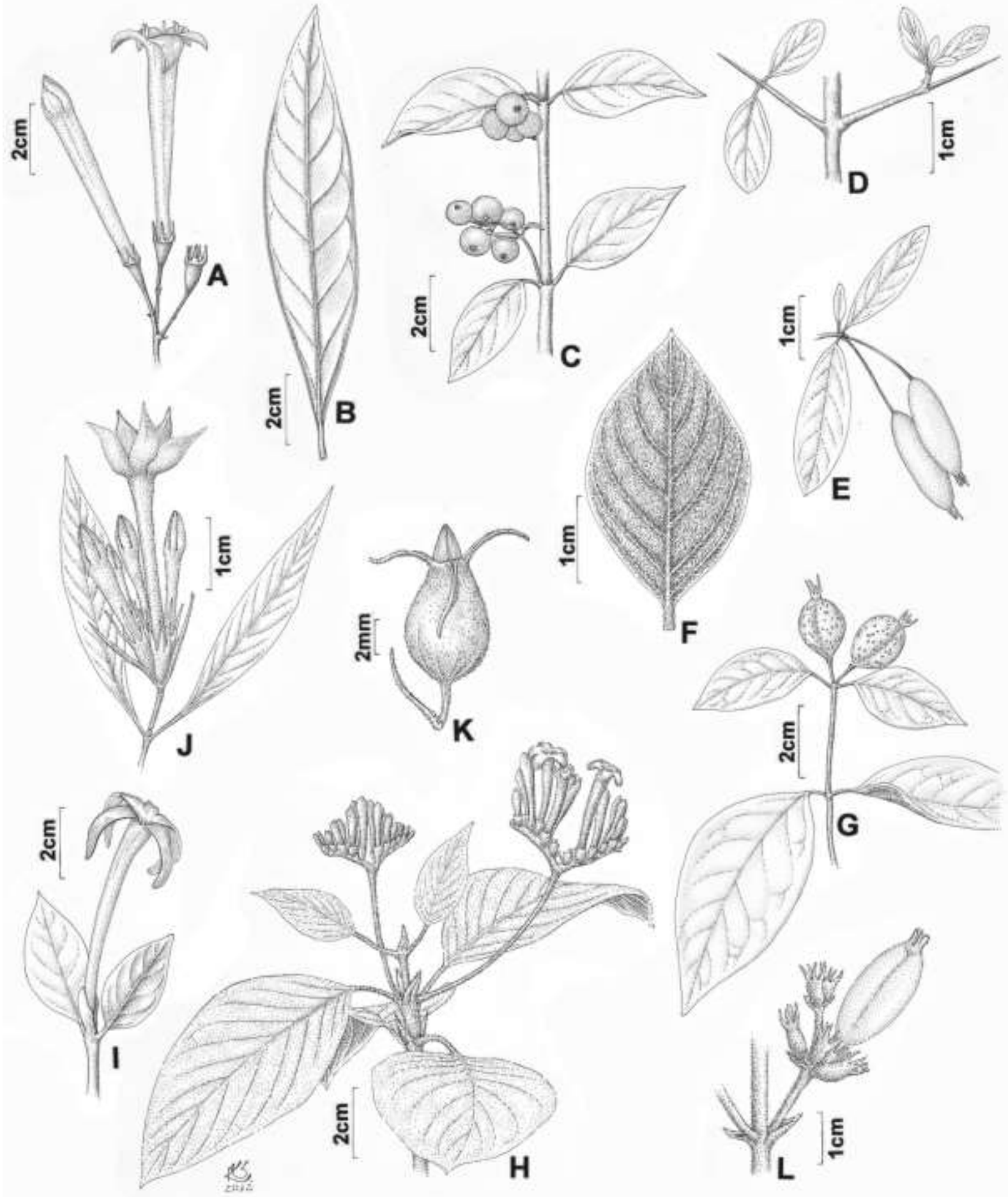

Fig. 2 - Arbustos com corolas geralmente vistosas, frutos capsulares ou bagas multisseminadas. A-B. Augusta longifolia. A. Inflorescência. B. Folha. C. Chiococca alba, Hábito. D-E. Chomelia obtusa. D. Detalhe dos espinhos. E. Ápice do ramo com frutos. F. Chomelia ribesioides, Folha. G. Coutarea hexandra, Ramo em fruto. H. Guettarda viburnoides, Hábito. I. Hillia parasitica, Flor aberta. J-K. Hindsia longiflora. J. Inflorescência. K. Fruto. L. Remijia ferruginea, Detalhe da infrutescência. (A-B: Romão 2400. C: Zappi 1834. D-E: Zappi 2194. F: Zappi 801. G: Zappi 2756. H: Zappi 2465. I: Hunt 6473. J-K: Riedel 914. L: Zappi 803). 
Flora da Serra do Cipó, Minas Gerais: Rubiaceae

ao sol ou à sombra de mata ciliar. Foi observada florescendo durante o ano inteiro e frutificando em fevereiro e março.

\section{Bathysa C. Pres}

Árvores pouco ramificadas, ramos quadrangulares, ramificação trifurcada. Estípulas inteiras, basalmente conatas, triangulares, persistentes. Folhas opostas, pecioladas. Flores bissexuadas, actinomorfas, 4-meras, em inflorescências paniculadas terminais e subterminais, prefloração imbricada; hipanto turbinado, tubo curto ou ausente, lobado; corola com prefloração imbricada, hipocrateriforme, pouco mais longa que o cálice, ovário 2-locular. Cápsula bivalvar, oblonga, septicida, com endocarpo flexível; sementes numerosas, tetraédricas a ligeiramente achatadas.

Chave para as espécies

1. Folhas com base arredondada; lacínios do cálice obtusos

3.1. B. australis

1 '. Folhas com base cuneada; lacínios do cálice agudos 3.2. B. nicholsonii

3.1. Bathysa australis (A.St.-Hil.) Hook. f. ex K.Schum. in Mart., Eichler \& Urb., FI. bras. 6(6): 239. 1889.

Nomes vulgares: autuparana, fumão (SP)

Fig. 3. A.

Árvores até $10 \mathrm{~m}$ alt., râmulos quadrangulares, castanhos, seríceos. Estípulas triangulares,18-32 mm compr., 6-14 mm larg., carena não evidente. Folhas opostas, pecioladas; pecíolo $30 \mathrm{~mm}$ compr., não sulcado; lâmina amplamente oval a oboval, base arredondada, ápice arredondado a obtuso, 20-40(-60) cm compr., $18-30 \mathrm{~cm}$ larg., cartácea, discolor, face abaxial rugosa e fosca, esparsamente pilosas, adaxial rugosa e fosca, escabra ou glabra, domácias ausentes; venação broquidódroma, nervuras na face abaxial salientes, curto-pilosas. Flores em amplas panículas multifloras terminais e subterminais (até o terceiro nó); pedúnculo 15-20(-30) cm compr., espesso; brácteas conspícuas; hipanto 1,2 $\mathrm{mm}$ compr., hirsuto, tubo ausente, lacínios obtusos, 0,3-0,4 $\mathrm{mm}$ compr.; corola $3 \mathrm{~mm}$ compr., alva, tubo curto, lobos eretos, ca. 1,5-2 mm compr.; estames exsertos, anteras ca. 0,8 mm compr.; estilete exserto, até $2 \mathrm{~mm}$ compr., hirsuto, estigma bilobado. Cápsulas 3-4 mm compr., obovoides, sésseis, epicarpo seríceo, endocarpo flexível, rompendo-se quando maduro; sementes numerosas, aplanadas, 0,4 $\mathrm{mm}$ compr.

Material examinado: Santana do Riacho, A.E. Luchi et al. 348, 7.XI.1995, estéril (SP); A.E. Luchi et al. 354, 7.XI.1995, estéril (SP).

Material adicional: Paraná: Morretes, Parque Estadual Marumbi, J.M. Silva 2242, 8.VII.1997, fl., fr. (MBM, SPF).

Bathysa australis ocorre na Bolívia e Brasil, onde se concentra na região leste do país. Os dois únicos registros da Serra do Cipó são estéreis, sendo possível determinar sua identidade por meio das folhas com base arredondada e nervuras aproximadas na base, e por se tratar de árvores maiores do que $B$. nicholsonii.
3.2. Bathysa nicholsonii K.Schum. in Mart., Eichler \& Urb., FI. bras. 6(6): 237. 1889.

Fig. 3. B-D.

Árvores a arvoretas até $5 \mathrm{~m}$ alt., râmulos quadrangulares, castanhos, seríceos. Estípulas triangulares,15-50 mm compr., 15-30 mm larg., com carena marcada, persistentes até o quinto nó. Folhas opostas, pecioladas; pecíolo 15-25 mm compr., profundamente sulcado; lâmina amplamente oval a oboval, base cuneada, ápice agudo a arredondado, 20-35(-40) cm compr., 12-17 cm larg., cartácea, concolor, face abaxial aveludada, pilosas, face adaxial levemente rugosa e fosca, glabra, domácias ausentes; venação broquidódroma, nervuras na face abaxial salientes, curto-pilosas. Flores em panículas multifloras terminais e subterminais (até o terceiro nó); pedúnculo 6-10 cm compr., espesso; brácteas conspícuas; hipanto $2 \mathrm{~mm}$ compr., hirsuto, tubo ausente, lacínios agudos, 0,5 mm compr.; corola $3 \mathrm{~mm}$ compr., alva, tubo curto, lobos fortemente reflexos, ca. 1,5-2 mm compr.; estames exsertos e reflexos, anteras ca. 1,5 mm compr.; estilete exserto, até $3 \mathrm{~mm}$ compr., hirsuto, estigma bilobado com ramos divergentes. Cápsulas 4-5 mm compr., turbinadas a obovoides, sésseis, epicarpo seríceo, endocarpo flexível, rompendo-se quando maduro; sementes numerosas, aplanadas, $0,5 \mathrm{~mm}$ compr.

Material examinado: Itambé do Mato Dentro, distrito de Santana do Rio Preto (Cabeça de Boi), APA do Parque Nacional da Serra do Cipó, M.F. Santos \& L.M. Borges 186, 17.XII.2007, fl. (BHCB, SPF); Terras de José Agostinho, 1923'46.9"S, 4324'07.4"W, M.F. Santos \& L.M. Borges 460, 15.XII.2007, fl. (SPF). Santana do Riacho, antiga estrada, A.E. Luchi et al. 358,7.XI. 1995, estéril (SP); Serra do Cipó, rodovia Belo Horizonte - Conceição do Mato Dentro, km 123, Córrego Três Pontinhas, A. Luchi CFSC 9808, 17.VII.1983, fr. (SPF); idem, J.R. Pirani \& I. Cordeiro CFSC 7678, 3.XI.1981, fl. (SPF).

Material adicional: Minas Gerais: Juiz de Fora, Morro do Imperador, D.S. Pífano et al. CESJ 35140, 28.XI.2001, fl. (CESJ, K); Viçosa, Fazenda de Grasiuma, 14.V.1930, Y. Mexia 4695, fr. (F, K). 


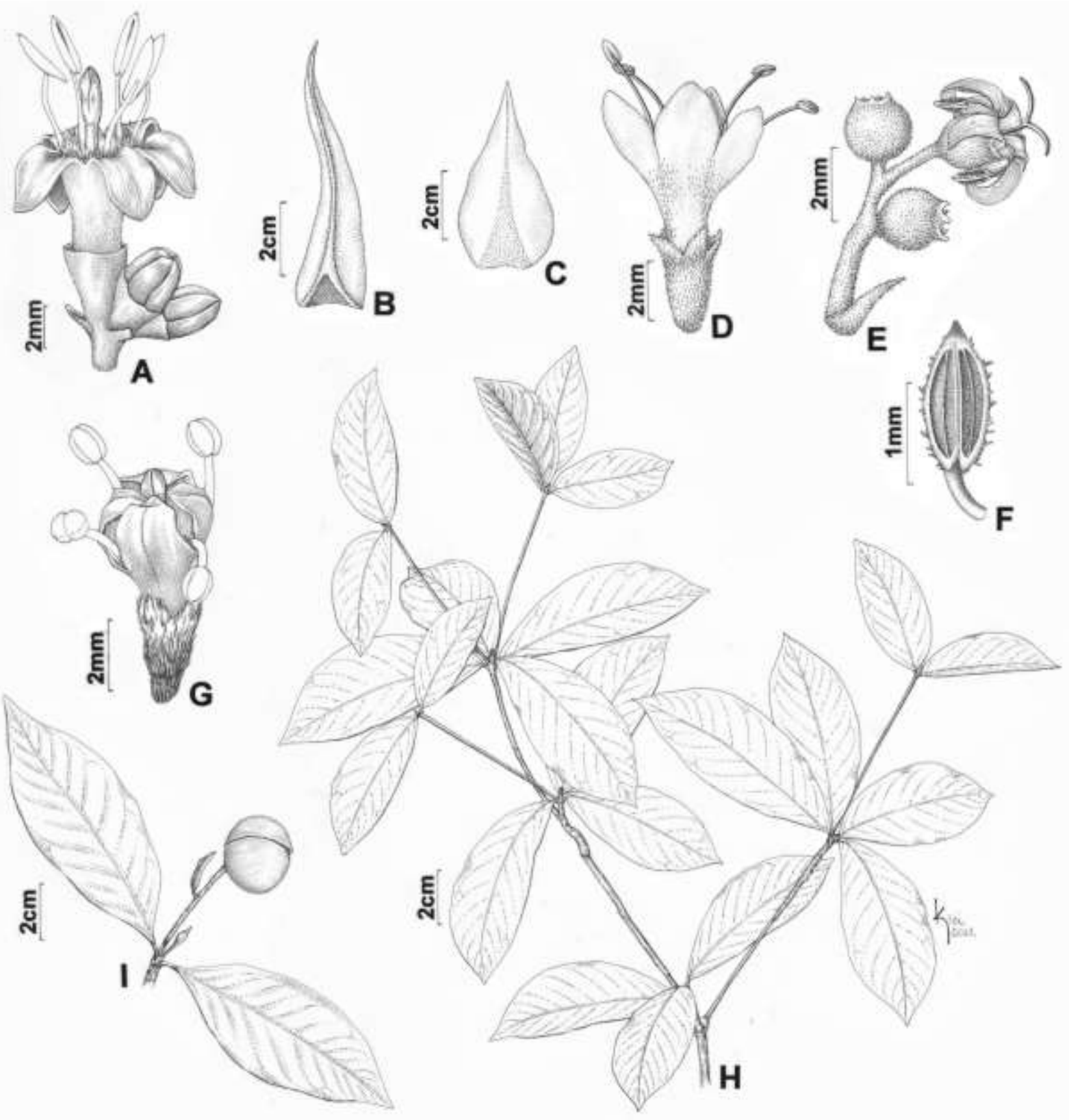

Fig. 3 - Árvores com frutos capsulares. A. Bathysa australis, Flor. B-D. Bathysa nicholsonii. B-C. Estípulas. D. Flor em vista lateral. E-F. Molopanthera paniculata. E. Detalhe da inflorescência. F. Antera. G. Schizocalyx cuspidatus, Flor. H-I. Simira sampaioana. H. Hábito. I. Ápice do ramo com fruto. (A: Silva 2242. B, D: Pifano s.n. CESJ 35140. C: Mexia 4695. E-F: Williams 6861. G: Andrade 729. H: Zappi 2753. I: Tamashiro 268). 
Flora da Serra do Cipó, Minas Gerais: Rubiaceae

Espécie endêmica dos estados de Minas Gerais, Espírito Santo e Rio de Janeiro, encontrada em matas ciliares. Na Serra do Cipó foi coletada com flores em setembro e dezembro e frutificando em agosto. Distingue-se de $B$. australis pelo porte menor, pelas folhas com base cuneada e flores com lobos da corola revolutos.

\section{Borreria G.Mey.}

Ervas a subarbustos eretos ou decumbentes, até $1 \mathrm{~m}$ alt., anuais ou perenes, simples ou ramificados; ramos quadrangulares, às vezes alados, a subcilíndricos. Estípulas geralmente conatas na base, fimbriadas no ápice, persistentes. Folhas opostas ou verticiladas, pecioladas ou sésseis. Flores bissexuadas, actinomorfas, 4-meras, geralmente sésseis, em inflorescências glomerulares densas, terminais e axilares; hipanto turbinado, tubo ausente, lobos (2-)4; corola com prefloração valvar, tubulosa, pouco mais longa que o tubo e lacínios do cálice, ovário 2-locular, lóculos uniovulados. Cápsula bivalvar, septicida, com endocarpo flexível; 2 sementes por fruto; sementes alongadas, com testa reticuladafoveolada, às vezes transversalmente sulcada.

Segundo Govaerts (2011), o gênero neotropical Borreria é sinônimo de Spermacoce, de ocorrência pantropical. Autores sul-americanos como Bacigalupo \& Cabral (2007a) mantêm esses gêneros distintos, o que foi também reconhecido no Catálogo de Plantas e Fungos do Brasil (Barbosa et al. 2010), posicionamento que persiste em tratamentos recentes para o Brasil (Barbosa et al. 2014). Trabalhos recentes de filogenia do grupo não apoiam a concepção ampla de Spermacoce incluindo Borreria como monofilético (Groeninckx et al. 2009), corroborando a circunscrição de Borreria com espécies neotropicais.

Chave para as espécies

1. Folhas lineares, nervuras secundárias pouco conspícuas ou inconspícuas.

2. Gemas axilares ausentes a pouco desenvolvidas, folhas opostas sem braquiblastos, folhas com ao menos $3 \mathrm{~cm}$ compr.

4.9. B. warmingii

2'. Gemas axilares desenvolvidas, folhas pseudoverticiladas pela presença de braquiblastos, folhas com menos de $2 \mathrm{~cm}$ compr.

3. Folhas suberetas

4.6. B. rosmarinifolia

3'. Folhas recurvadas 4.5. B. cf. quadrifaria

1'. Folhas expandidas, nervuras secundárias conspícuas.

5. Cápsulas com deiscência parcial, liberando apenas uma semente 4.3. B. ocymifolia

5'. Cápsulas com deiscência plena, liberando ambas as sementes.

6. Ramos quadrangulares, alados.

7. Folhas patentes a reflexas; corola alva

4.7. B. schumannii

7'. Folhas eretas; corola lilás-azulada 4.4. B. poaya

6'. Ramos cilíndricos ou costados, não alados.

8. Folhas com lâmina glabra a esparsamente indumentada, com margem estrigosa, parecendo microscopicamente serreada

8'. Folhas com lâmina glabra a densamente indumentada, margem pilosa ou glabra, mas não estrigosa.

9. Arbustos muito ramificados e com folhagem densa, glabros ou glabrescentes

9'. Subarbustos pouco ramificados, densamente pilosos.

10. Plantas ultrapassando $40 \mathrm{~cm}$ alt., folhas membranáceas

$10^{\prime}$. Planta até $40 \mathrm{~cm}$ alt., folhas coriáceas

4.2. B. cf. dasycephala ... 4.8. B. verticillata

... 4.1. B. capitata 4.10. Borreria sp. 1

4.1. Borreria capitata (Ruiz \& Pav.) DC., Prodr. 4: 545. 1830.

Nome vulgar: vassoura-de-botão.

Fig. 4. A.

Subarbustos eretos, ramificados acima da base, $40-100 \mathrm{~cm}$ alt.; ramos e râmulos cilíndricos ou levemente costados, não alados, densamente pilosos, tricomas estrigosos longos, avermelhados, amarelados ou alvos. Estípulas semilunares, conatas, 2-3 mm compr., $4 \mathrm{~mm}$ larg., laciniadas, 6-8 lacínios filiformes até $7 \mathrm{~mm}$ compr., persistentes. Folhas opostas a falsamente verticiladas, sésseis; lâmina lanceolada, base atenuada, ápice agudo, $15-40 \mathrm{~mm}$ compr., 4-10 mm larg., membranácea, discolor, glabra a pilosa; venação broquidódroma ou eucamptódroma, nervuras secundárias subparalelas salientes na face abaxial. Flores em glomérulos densos apicais e axilares subtendidos por 4 brácteas foliáceas alargadas; hipanto $2 \mathrm{~mm}$ compr., estrigoso, tubo ausente, lacínios 4, agudos, $1 \mathrm{~mm}$ compr., ciliados; corola $2 \mathrm{~mm}$ compr., infundibuliforme, alva, tubo curto, lobos ereto-patentes, ca. $1 \mathrm{~mm}$ compr.; flores protogínicas, anteras ca. $0,5 \mathrm{~mm}$ compr.; estilete até 2 $\mathrm{mm}$ compr., estigma globoso. Cápsulas $3 \mathrm{~mm}$ compr., obovoides, sésseis, epicarpo estrigoso, endocarpo flexível, rompendo-se quando maduro; sementes estreitamente elipsoides, ca. $2 \mathrm{~mm}$ compr., com fenda adaxial; testa castanho-escura, transversalmente sulcada. 


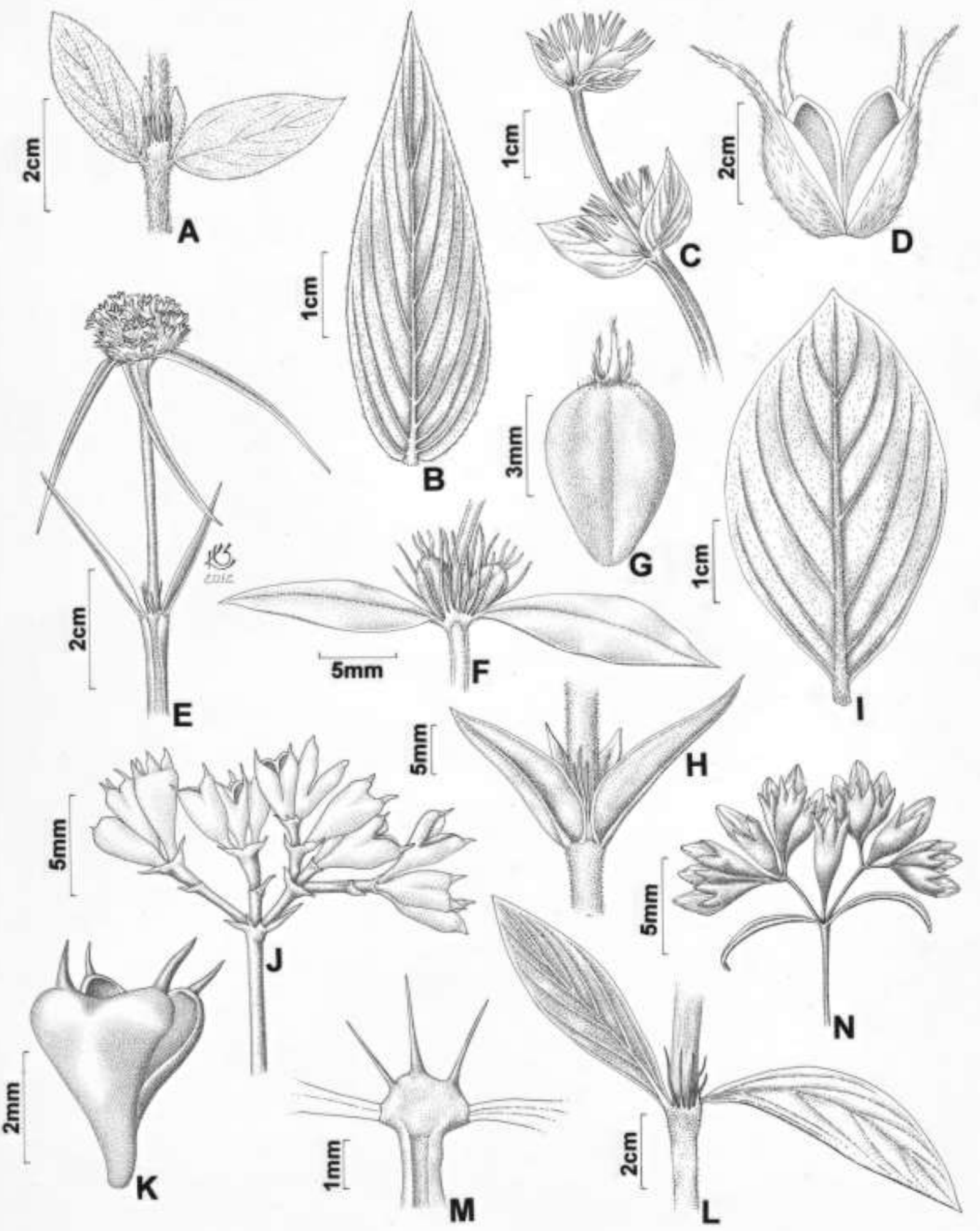

Fig. 4 - Herbáceas a subarbustivas da tribo Spermacoceae (excl. Emmeorhiza). A. Borreria capitata, Detalhe do ramo. B-C. Borreria poaya. B. Folha. C. Ápice do ramo. D. Borreria schumannii, Fruto aberto. E. Borreria warmingii, Ápice do ramo. F-G. Diodella apiculata. F. Detalhe do ramo. G. Fruto. H. Diodella mello-barretoi, Detalhe do ramo. I. Diodella radula, Folha. J-K. Galianthe angustifolia. J. Infrutescência. K. Fruto aberto. L. Galianthe grandifolia, Detalhe do ramo. M-N. Galianthe peruviana. M. Estípula. N. Inflorescência. (A: Zappi 2622. B-C: CFCR 6029. D: Zappi 1895. E: Zappi 1912A. F-G: Zappi 2526. H: MelloBarreto 20361. I: Zappi 2277. J-K: Mello Barreto 8986. L: Irwin 22835. M-N: Zappi 2774). 
Material examinado: Conceição do Mato Dentro, Capão Redondo, Fazenda Boa Esperança, N. Roque et al. 137, 13.II.1996, fl., fr. (SPF). Congonhas do Norte, Serra Talhada (setor nordeste da Serra do Cipó), ca. 6 km SW da estrada Congonhas do Norte - Gouveia, entrada a 3,7 km NW de Congonhas do Norte, estrada pelo alto da serra em local denominado localmente como Retiro dos Pereiras, 1850'60"S, 4344'60"W, J.R. Pirani et al. 5749, 4.Il.2009, fl., fr. (SPF). Jaboticatubas, along from village of Almeida to city of Conceição do Mato Dentro, G. Eiten \& L.T. Eiten 11026 , 11.III.1969, fl. (SP); Serra do Cipó, rodovia Lagoa Santa Conceição do Mato Dentro - Diamantina, km 120, J. Semir \& M. Sazima CFSC 2676, 21.VII.1972, fl. (SP, SPF); idem, km 124, A.B. Joly et al. CFSC 2403, 29.V.1972, fl. (SP); idem, km 126, J. Semir \& A.M. Joly CFSC 3796, 6.I.1973, fl., fr. (SP, UEC); idem, km 127, J. Semir \& M. Sazima CFSC 734, 7.II.1972, fl. (SP, SPF, UEC); idem, J. Semir \& M. Sazima CFSC 2617, 19.VII.1972, fl. (SP); idem, km 128, A.B. Joly et al. CFSC 2438, 29.V.1972, fl., fr. (SP, UEC); idem, km 131 , A.B. Joly et al. CFSC 1243, 6.III. 1972, fl. (SP); idem, km 132 , A.B. Joly \& J. Semir CFSC 268, 7.VI.1970, fl. (SP, UEC); idem, M. Sazima \& J. Semir CFSC 3877, 24.II.1973, fl. (SP, SPF); idem, J. Semir \& M. Sazima CFSC 2021, 30.IV.1972, fl. (SP); idem, km 140, A.B. Joly et al. CFSC 1275, 6.III. 1972, fl. (SP); idem, km 141, A.B. Joly et al. CFSC 1830, 17.IV.1972, fl. (SP); idem, A.B. Joly et al. CFSC 1841, 17.IV.1972, fl. (SP); idem, km 142, J. Semir \& M. Sazima CFSC 2743, 22.VII.1972, fl. (SP). Santana de Pirapama, Serra do Cipó, acesso pela Faz. Inhame, 1855'13"S, 4347'23"W, D.C. Zappi et al. 3327, 23.III.2011, fl. (K, SPF); Capela de São José, Trilha da Senhorinha, caminho a Congonhas do Norte, 185' 4,8"S, 43ㄴ5'18,6"W, D.C. Zappi et al. 2622, 25.XI.2009, fl., fr. (K, RB, SPF). Santana do Riacho, Serra do Cipó, Rodovia Belo Horizonte - Conceição do Mato Dentro, próximo à bifurcação do Morro do Pilar, 1913'13"S, 4329'57"W, V.C. Souza et al. 25083, fl., fr. (ESA, SPF); idem, M.T.V.A. Campos \& E.D.P. de Souza CFSC 13510, 20.XI.1993 (SPF); idem, km 135, próximo ao Palácio, H.C. Lima 370, 25.V.1978, fl., fr. (RB); idem, km 118, F. Vale 11, 5.X.1994, fl., fr. (SPF); idem, km 125, J.R. Pirani et al. CFSC 12057, 26.III.1991, fl. (SPF); idem, km 127, N.S. Chukr et al. CFSC 9449, 13.XII.1985, fl., fr. (SPF); idem, km 128, F. Vale s.n., 6.VII.1994, fl., fr. (SPF 125285); idem, km 140, A. Furlan \& M.G. Sajo CFSC 5963, 29.II.1980, fl. (SP); Retiro do Alto do Palácio, $25 \mathrm{~km}$ NE de Cardeal Mota caminho a Conceição do Mato Dentro, M.M. Arbo et al. 4260, 16.V.1980, fl., fr. (SPF); 7-12 km de Santana do Riacho, camino a Lapinha, ca. 1910'S, 4341'W, M.M. Arbo et al. 4835, 11.II.1991, fl., fr. (SPF); s.I., W.R. Anderson et al. 36219, 18.Il.1972, fl. (UEC); RPPN Brumas do Espinhaço e Ermo do Gerais, F.M. Fernandes et al. 398, 30.I.2013, fl. (BHZB, SPF); idem, M.G.C. Fernandes 1728, 27.XI.2012, fl. (BHZB, SPF). Sem município, Retiro do Alto do Palácio, F. Barros 2767, 1.V.1993, fl. (SP, SPF).

Amplamente distribuída na América do Sul, Borreria capitata ocorre em quase todos os estados do Brasil com a exceção da região amazônica (Barbosa et al. 2014), tanto em cerrados, campos e outras formações abertas, como em locais perturbados, à beira de estradas. Alguns espécimes coletados em Minas Gerais depositados no Herbário RB (H.C. Lima 370) estão determinados como Borreria brachystemonoides Cham. \& Schltdl., mas ao comparar os espécimes com o material-tipo desta espécie coletado por Sello (Sello s.n., K, HAL), verificamos que essas determinações estão equivocadas, sendo $B$. brachystemonoides uma erva delicada de $20 \mathrm{~cm}$ alt., com râmulos costados e ciliados e folhagem acinzentada, e, segundo Bacigalupo \& Cabral (1996), possuindo um elaiossomo na face ventral da semente, que possui testa lisa. Portanto, B. capitata distingue-se dela por seu porte maior, ramos densamente pilosos, folhagem verdeolivácea e sementes sem elaiossomo, com testa transversalmente sulcada.

4.2. Borreria cf. dasycephala (Cham. \& Schltdl.) Bacigalupo \& E.L. Cabral, Opera Bot. Belg. 7: 297308. 1996.

Ervas prostradas, ramificadas na base, $20 \mathrm{~cm}$ alt.; ramos e râmulos quadrangulares, sulcados, não alados, glabros ou com ocasionais projeções escabras. Estípulas semilunares, conatas, 2-3 mm compr., $3 \mathrm{~mm}$ larg., laciniadas, 5-7(-9) lacínios filiformes até $2 \mathrm{~mm}$ compr., persistentes. Folhas opostas, pecioladas; pecíolo 3-8 mm compr.; lâmina lanceolada a estreitamente oblonga, base longamente atenuada, ápice agudo a acutiúsculo, 20-35(-40) mm compr., 6-15 mm larg., membranácea, levemente discolor, secando verde-oliváceas, glabra a esparsamente pilosa, margem estrigosa; venação eucamptódroma, nervuras secundárias planas, face abaxial com algumas projeções escabras sobre a nervura central. Flores em glomérulos densos apicais e axilares subtendidos por 4 brácteas foliáceas alongadas; hipanto $2,5 \mathrm{~mm}$ compr., estrigoso no ápice, tubo ausente, lacínios 4, agudos, 1,5mm compr., ciliados; corola 1,5 mm compr., infundibuliforme, alva, tubo curto, lobos ereto-patentes, ca. $1 \mathrm{~mm}$ compr.; flores protogínicas, anteras ca. $0,8 \mathrm{~mm}$ compr.; estilete até $2 \mathrm{~mm}$ compr., estigma bilobado. Cápsulas 2,2-2,5 $\mathrm{mm}$ compr., obovoides, sésseis, epicarpo estrigoso na parte superior, endocarpo papiráceo, rompendo-se quando maduro; sementes estreitamente elipsoides 2 $\mathrm{mm}$ compr., com fenda adaxial., testa enegrecida, rugulosa.

Material examinado: Santana de Pirapama, Serra do Cipó, acesso pela Faz. Inhame, 1859'26"S, 4346'38"W, D.C. Zappi et al. 3336, 23.III.2011, fl. (K, SPF).

Material adicional: São Paulo: capital, Horto Fac. Farmácia, W. Hoehne 864, 19.XI.1941, fl., fr. (SPF); idem, M. Kuhlmann s.n., I.1936, fl., fr. (SP, SPF 13878).

Espécie ruderal, amplamente distribuída na parte sul da América do Sul, desde o Peru e Equador até Uruguai e Argentina; no Brasil, foi registrada em todas as regiões e na maioria dos estados (Barbosa et al. 2014). Na Serra do Cipó, ocorre em solos perturbados e em pastagens, e foi coletada em fruto durante o mês de março. Devido à falta de material em flor, não foi possível realizar uma identificação definitiva deste táxon. Borreria dasycephala pode ser reconhecida pelo seu hábito prostrado e as projeções denteadas na base das folhas, que também possuem margem microscopicamente serreada. 
4.3. Borreria ocymifolia (Willd. ex Roem. \& Schult.) Bacigalupo \& E.L. Cabral, Opera Bot. Belg. 7: 297-308. 1996.

Ervas suberetas, esparsamente ramificadas acima da base, (30-)40-60(-100) cm alt.; ramos e râmulos levemente quadrangulares, estriados, esparsamente vilosos com tricomas longos, transparentes. Estípulas semilunares, não conatas, 1$3 \mathrm{~mm}$ compr., 2-4 mm larg., laciniadas, 8-12 lacínios filiformes 4-5 mm compr., persistentes. Folhas opostas, pecioladas; pecíolo 5-8 $\mathrm{mm}$ compr., alado; lâmina lanceolada a oval, base longamente atenuada, ápice agudo a longamente acuminado, (30-)40-55 mm compr., (10-)20-25 mm larg., membranácea, discolor, face abaxial oliváceo-clara, face adaxial oliváceoescura, esparsamente pilosa em ambas as faces; venação eucamptódroma, nervuras secundárias 5-7(8) pares, subparalelas, salientes e amarelas na face abaxial, impressas na face adaxial. Flores em glomérulos paucifloros axilares, sem brácteas; hipanto $2 \mathrm{~mm}$ compr., curtamente piloso, tubo curto, lacínios 4 , deltoides, 0,2 mm compr.; corola 2,5-3,5 mm compr., alva, infundibuliforme, lobos reflexos, ca. $1 \mathrm{~mm}$ compr.; flores protogínicas, anteras ca. 0,3 $\mathrm{mm}$ compr.; estilete até $4 \mathrm{~mm}$ compr., estigma capitado. Cápsulas 2,5-3 mm compr., estreitamente obovoides, curtamente pedun-culadas, epicarpo viloso, endocarpo flexível, metade do qual permanece inteiro e a outra metade rompendo-se quando maduro, liberando apenas uma semente; sementes estreitamente elipsoides 2,5 mm compr., com fenda adaxial, testa nigrescente, minutamente reticulada, com sulco transversal pouco visível.

Material examinado: Santana do Riacho, Serra do Cipó, acesso pela Faz. Inhame, Faz. Toucan Cipó, 1900'20"S, 4346'34"W, D.C. Zappi et al. 2187, 16.III.2009, fl., fr. (K, RB, SPF).

Material adicional: Minas Gerais: Santo Hipólito, cerca de $5 \mathrm{~km}$ além de Santo Hipólito em direção a Monjolos, no antigo leito da estrada de ferro, 1817'17"S, 4411'06"W, R. Mello-Silva et al. 1273, 23.III.1997, fl., fr. (K, SPF). São Paulo: Cananéia, estrada Cananéia - Pariquera-açu (via ponte), cerca de $19 \mathrm{~km}$ de Cananéia, 245'2,9"S, 47-50'30,3"W, M.Y. Nakagomi et al. 8, 6.IX.1994, fl., fr. (SPF); Miracatu, Fazenda Itereí, Serra de Paranapiacaba, 24응' 47ํ1'W, J.R. Pirani et al. 3149, 20.IV.1994, fl., fr. (SPF). Rio de Janeiro, Tijuca, P. Carauta 445, 17.X.1967, fr. (GUA, K).

Borreria ocymifolia ocorre em regiões tropicais e subtropicais do continente americano. No Brasil, possui ampla distribuição em todos os biomas (Barbosa et al. 2014). Na Serra do Cipó, foi coletada em vegetação perturbada nas proximidades de mata seca semidecidual, com flores e frutos em março. 1830.

4.4. Borreria poaya (A. St.-Hil.) DC., Prodr. 4: 549.

Nome vulgar: poaia.

Fig. 4. B-C.

Ervas a subarbustos ramificados acima da base, eretos ou decumbentes, $30-60 \mathrm{~cm}$ alt.; râmulos quadrangulares, com vértices alados, glabros. Estípulas semilunares, conatas, $2 \times 4-5 \mathrm{~mm}$, laciniadas, lacínios 4-6, filiformes até $8 \mathrm{~mm}$ compr., persistentes. Folhas opostas, sésseis; lâmina lanceolada, base arredondada, cordada ou truncada ápice agudo, 25-40 mm compr., 10-15 mm larg., cartácea, concolor, amarelada quando seca, glabra a pilosa, face adaxial canaliculada; venação eucamptódroma, nervuras secundárias subparalelas, salientes na face abaxial, canaliculadas na face adaxial. Flores em glomérulos densos apicais e axilares, subtendidos por 2 brácteas foliáceas alargadas; hipanto 7-8 mm compr., tubo curto, lacínios 4, agudos, 3-4 mm compr., ciliados; corola $8 \mathrm{~mm}$ compr., alva, tubo longo, lobos ereto-patentes, ca. 2 $\mathrm{mm}$ compr.; flores (protoginia não observada), anteras ca. $1 \mathrm{~mm}$ compr.; estilete até $7 \mathrm{~mm}$ compr., estigma bífido, lobos filiformes. Cápsulas $7 \mathrm{~mm}$ compr., obovoides, sésseis, epicarpo estrigoso, endocarpo flexível, rompendo-se quando maduro; sementes elipsoides, 2,5 mm compr., com fenda adaxial; sementes maduras não observadas.

Material examinado: Jaboticatubas, nas proximidades da divisa do Parque rumo a Conceição do Mato Dentro, H.F. Leitão Filho et al. 27277 [UEC 61498], 7.XII.1992, fl., fr. (UEC); Serra do Cipó, rodovia Lagoa Santa - Conceição do Mato Dentro - Diamantina, km 115, J. Semir et al. CFSC 4101, 29.IV.1973, fl. (SP); idem, J. Semir \& M. Sazima CFSC 490, 13.XII.1971, fl. (SP, UEC); idem, J. Semir \& M. Sazima CFSC 741, 7.II.1972, fl., fr. (SP, UEC); idem, km 131, M.S.F. Silvestre 9068, 3.XI.1978, fl., fr. (UEC); idem, km 132, A.B. Joly et al. CFSC 269, 7.VI.1970, fl., fr. (SP, UEC); idem, A.B. Joly et al. CFSC 1356, 6. III.1972, fl. (SP); idem, A.B. Joly \& J. Semir CFSC 3136, 21.VIII.1972, fl. (SP); idem, km 132, A.B. Joly CFSC 3678, 4.XI.1972, fl., fr. (SP, UEC); idem, J. Semir et al. CFSC 2353, 28.V.1972, fl. (SP); idem, M. Sazima \& J. Semir CFSC 3881, 16 a 24.II.1973, fl., fr. (SP, UEC); idem, entre $\mathrm{km} \mathrm{137-138,A.B.} \mathrm{Joly} \mathrm{et} \mathrm{al.} \mathrm{CFSC} \mathrm{343,}$ 8.VI.1970, fl., fr. (SP, UEC); idem, km 138, A.B. Joly et al. CFSC 2178, 27.V.1972, fl. (SP); idem, km 138-9, A.B. Joly et al. CFSC 2178, 27.V.1972, fl., fr. (SP, UEC); idem, km 139, A.B. Joly et al. CFSC 1940, 17.IV.1972, fl., fr. (SP, UEC). Santana do Riacho, Serra do Cipó, estrada Belo Horizonte Conceição do Mato Dentro, Cardeal Mota, F. Feres et al. 98/27, 15.XII.1998, fl. (UEC); 10-20 km NE de Cardeal Mota, caminho a Conceição do Mato Dentro, 1920'S, 43ํ3' W, M.M. Arbo et al. 4158, 15.V.1990, fl., fr. (SPF); km 120-121, E. Forero et al. 7885 [CFSC 8798], 6.IX.1980, fl. (SP); idem, km 123, Córrego Três Pontinhas, R. Harley et al CFCR 6029, 15.XI.1984, fl. (K, SPF); idem, km 116, estrada para Salitreiro, L. Rossi \& M.C.E. Amaral CFSC 7281, 19.IV.1981, fl. (SPF); Fazenda Cachoeira da Capivara, 1914'57"S, 4332'42"W, V.C. Souza et al. 25160, 5.VII.2001, fl., fr. (SPF); Parque Nacional da Serra do Cipó, junto à sede do IBAMA do Alto do Palácio, J.R. Pirani et al. CFSC 12850, 7.XII.1991, fl. (SPF);

Material adicional: Minas Gerais: Diamantina, estrada para Conselheiro Mata, $4 \mathrm{~km}$ da bifurcação para Curvelo, $B$. Stannard et al. CFCR 6172, 19.XI.1984, fl. (K, SPF); $12 \mathrm{~km}$ NE of Diamantina, road to Mendanha, H.S. Irwin et al. 22785, 28.I.1969, fl. (K, NY); $26 \mathrm{~km} \mathrm{NE}$ of Patrocínio, Morro das Pedras, H.S. Irwin et al. 25568, 29.I.1970, fl., fr. (K, NY); perto do antigo leito da estrada de ferro, próximo a Guinda, J.R. Pirani et al. CFCR 11782, 9.I.1988, fl. (SPF).

Borreria poaya é amplamente distribuída pelo Brasil, ocorrendo em campos e cerrados sobre solo 
Flora da Serra do Cipó, Minas Gerais: Rubiaceae

arenoso (Barbosa et al. 2014). Na Serra do Cipó, foi coletada com flores entre novembro e junho, e frutificando em junho.

4.5. Borreria cf. quadrifaria E.L. Cabral, Parodiana 4: 138. 1986.

Ervas a subarbustos eretos, ramificados acima da base, $15-20 \mathrm{~cm}$ alt.; ramos cilíndricos, râmulos quadrangulares, glabros, vernicosos e diminutamente pilosos próximo aos nós. Estípulas semilunares a truncadas, conatas, $2-3 \times 3-4 \mathrm{~mm}$, laciniadas, 3-5 lacínios filiformes até $4 \mathrm{~mm}$ compr., persistentes ou decíduos. Folhas opostas a falsamente verticiladas, sésseis; lâmina lanceolada, base truncada, margem revoluta, ápice agudo, recurvada,10-18 mm compr., 1$2 \mathrm{~mm}$ larg., cartácea,concolor, verde-escura, glabra; nervuras inconspícuas. Flores em glomérulos densos apicais e axilares subtendidos por 2-4 brácteas foliáceas estreitas, recurvadas, agudas; hipanto 2,5-3 $\mathrm{mm}$ compr., glabro, tubo curto, lacínios 2, agudos, 1,11,3 mm compr., ciliados; corola 1-1,2 mm compr., alva, tubo curto, reto, lobos reflexos, ca. 0,6-0,8 mm compr.; flores não protogínicas, anteras ca. 0,3-0,4 mm compr.; estilete até $2 \mathrm{~mm}$ compr., estigma bilobado. Cápsulas 2,5 mm compr., estreitamente obovoides, sésseis, epicarpo glabro, endocarpo flexível; sementes estreitamente elipsoides 1-1,2 mm compr., com fenda adaxial pronunciada; testa castanho-avermelhada, lisa.

Material examinado: Santana de Pirapama, Serra do Cipó, acesso pela Faz. Inhame, Trilha da Senhorinha,

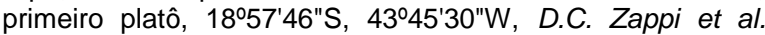
1847, 8.III.2009, fl., fr. (K, RB, SPF).

Material adicional: Goiás: Serra Dourada, $15 \mathrm{~km}$ leste da cidade, W.W. Thomas 5805, 9.II.1988, fl. (NY, SPF).

Esta espécie ocorre na Argentina, Bolívia, Paraguai e no Brasil, nos estados de Goiás, Mato Grosso do Sul, Minas Gerais, São Paulo e Paraná (Barbosa et al. 2014). O material coletado na Serra do Cipó apresenta folhas mais pronunciadamente recurvas do que o material proveniente de Goiás (Thomas 5805), identificado por E. Cabral. Na Serra do Cipó, foi coletada em campo limpo com solo arenoso branco, florescendo e frutificando em março. Protoginia não foi observada nos exemplares examinados.

4.6. Borreria rosmarinifolia E.L. Cabral \& Bacigalupo, Acta Bot. Brasil. 11: 48. 1997.

Ervas eretas, ramificadas a partir da metade da altura da planta, $30-40 \mathrm{~cm}$ alt.; ramos e râmulos cilíndricos a costados, não alados, glabros nas porções mais velhas e esparsa a densamente estrigosos nas demais porções, tricomas curtos, alvos. Estípulas semilunares, conatas, bainha 0,7-1,0 x 0,71,5 mm, laciniadas, 5-7 lacínios filiformes, até $4 \mathrm{~mm}$ compr., persistentes. Folhas falsamente verticiladas, sésseis; lâmina acicular, base truncada, ápice agudo,
6-18 mm compr., 0,3-0,8 mm larg., coriácea, discolor, face abaxial glabra, avermelhada quando seca, face adaxial glabra, fosca, verde-clara quando seca; venação uninérvea, nervura primária saliente na face abaxial. Flores em glomérulos densos apicais subtendidos por 4 brácteas alargadas na base, tornando-se abruptamente aciculares; hipanto 2-2,3 $\mathrm{mm}$ compr., estrigoso, tubo ausente, lacínios 4, agudos, 1-1,2 mm compr., ciliados apenas próximo à base; corola $3,5 \mathrm{~mm}$ compr., alva, tubo curto, lobos ereto-patentes, 1,75 $\mathrm{mm}$ compr., flores protogínicas, anteras ca. $0,9 \mathrm{~mm}$ compr.; estilete até $2,5 \mathrm{~mm}$ compr., estigma globoso. Frutos não vistos.

Material examinado: Jaboticatubas, Rodovia Lagoa Santa - Conceição do Mato Dentro - Diamantina, km 115, A.B. Joly et al. CFSC 830, 4.III.1972, fl., fr. (UEC). Santana do Riacho, Rodovia Belo Horizonte - Conceição do Mato Dentro, km 106, 1917'N, 4336'W, G.M. Faria \& M. Mazucato 1990, s.d., fl. (SPF).

Borreria rosmarinifolia é endêmica da Serra do Cipó, ocorrendo em campo rupestre sobre solo arenoso-rochoso (Cabral \& Bacigalupo 1997a). Diferencia-se facilmente das demais espécies de Borreria por suas folhas aciculares. Foi coletada com flores nos meses de fevereiro, março e maio.

4.7. Borreria schumannii (Standley ex Bacigalupo) E.L. Cabral \& Sobrado, Acta Bot. Bras. 25(2): 266. 2011.

Fig. 4. D.

Ervas eretas, ramificadas acima da base, 30$50(-200) \mathrm{cm}$ alt.; ramos e râmulos quadrangulares, ligeiramente vilosos com alguns tricomas recurvados, amarelados. Estípulas semilunares, conatas, 2-3 x 2-5 $\mathrm{mm}$, laciniadas, 5-8 lacínios, filiformes, até $5 \mathrm{~mm}$ compr., persistentes. Folhas opostas, sésseis a curtamente pecioladas; pecíolo até $2 \mathrm{~mm}$; lâmina lanceolada a oval, base truncada, ápice agudo, 25-60 mm compr., 10-20 mm larg., membranácea, discolor, face abaxial verde-clara, pilósula, face adaxial olivácea, glabra; venação eucamptódroma, nervuras secundárias subparalelas, salientes na face abaxial, impressas na face adaxial. Flores em glomérulos densos axilares ebracteados; hipanto 2,5 mm compr., pilósulo, tubo curto, lacínios 4, agudos, 1,5 mm compr., ciliados; corola 4-4,2 mm compr., alva, tubo curto, lobos patentes, ca. $1 \mathrm{~mm}$ compr.; flores protogínicas, anteras ca. 0,3 mm compr.; estilete até 5 $\mathrm{mm}$ compr., estigma bilobado. Cápsulas $3 \mathrm{~mm}$ compr., obovoides, sésseis, epicarpo estrigoso, endocarpo flexível, rompendo-se quando maduro; sementes estreitamente elipsoides $2 \mathrm{~mm}$ compr., com fenda adaxial; testa nigrescente minutamente reticulada.

Material examinado: Jaboticatubas, Rodovia Lagoa Santa - Conceição do Mato Dentro - Diamantina, km 126, A.B. Joly et al. CFSC 4663, 20.X.1973, fl. (SP, UEC). Santana de Pirapama, Serra do Cipó, acesso pela Faz. Inhame, Trilha da Senhorinha, 1858'07"S, 4345'08"W, D.C. 
Zappi et al. 1895, 8.III.2009, fl., fr. (K, RB, SPF). Santana do Riacho, estrada Lagoa Santa a Conceição do Mato Dentro, $\mathrm{km} 109$ (antigo 114), E. Forero et al. 7771 [CFSC 8693], 6.IX. 1980, fl., fr. (SP); rodovia Belo Horizonte - Conceição do Mato Dentro, km, 126, J. Semir et al. CFSC 5596, 14.VIII.1979, fr. (SP, SPF).

Material adicional: Espírito Santo: Santa Teresa, Saltinho, L. Kohlmann et al. 3864, 7.VI.2001, fr. (K, MBML). Minas Gerais: Diamantina, Fundo do Matador, Y. Mexia 5849, 16.V.1931, fl. (F, K).

Borreria schumannii distribui-se na Argentina, Paraguai, Bolívia e Brasil (Govaerts 2013), onde existem registros no Pará, Rondônia, Mato Grosso, Goiás, Mato Grosso do Sul, Minas Gerais, São Paulo, Espírito Santo, Paraná e Santa Catarina (Barbosa et al. 2014). Na Flora de Santa Catarina, Delprete (2005) trata Borreria sob o gênero Spermacoce, sendo que esta espécie aparece como Spermacoce schumanii (Standley ex Bacigalupo) Delprete. Segundo Delprete (2005), Delprete \& Kirkbride (2008) e Govaerts (2011), o sinônimo Borreria flavovirens Bacigalupo e E.L. Cabral é um nome supérfluo, portanto ilegítimo, porém não existia até o momento uma combinação deste epíteto específico sob o gênero Borreria. Este problema taxonômico foi retificado por meio da combinação apresentada por Cabral et al. (2011). Na Serra do Cipó, B. schumannii foi coletada em campo cerrado em solo arenoso, com flores e frutos maduros em março.

4.8. Borreria verticillata (L.) G.Mey., Prim. FI. Essequib. 83. 1818.

Nome vulgar: vassoura-de-botão

Ervas a subarbustos eretos, ramificados acima da base, 10-40(-50) cm alt.; ramos cilíndricos, râmulos estriados, levemente quadrangulares, esparsamente pilosos, especialmente na região apical dos entrenós, tricomas curtos, alvos. Estípulas semilunares a truncadas, conatas, 2-3 x 4-5 mm, laciniadas, lacínios 5-7, filiformes, até $5 \mathrm{~mm}$ compr., persistentes. Folhas opostas a falsamente verticiladas, sésseis; lâmina lanceolada, base longamente atenuada, margem revoluta na parte basal, ápice agudo, 10-20 mm compr., 2-5 mm larg., membranácea, discolores, face abaxial verde-clara, face adaxial fosca, verde-escura, glabra a hispídula; venação eucamptódroma, nervuras secundárias subparalelas conspícuas. Flores em glomérulos densos apicais e axilares subtendidos por 2(-4) brácteas foliáceas estreitas; hipanto 2,5-3 mm compr., estrigoso, tubo ausente, lacínios agudos, 2, 1,1-1,3 mm compr., ciliados; corola 2,5 mm compr., infundibuliforme, alva, tubo curto, lobos ereto-patentes, ca. 1,2 mm compr.; flores (protoginia não observada); anteras ca. 0,8-1 $\mathrm{mm}$ compr.; estilete até $3 \mathrm{~mm}$ compr., estigma bilobado. Cápsulas $2 \mathrm{~mm}$ compr., obovoides, sésseis, epicarpo glabro, endocarpo flexível (rompimento não observado); sementes estreitamente elipsoides 1,2 $\mathrm{mm}$ compr., com fenda adaxial circundada por cristais de sílica, testa castanho-avermelhada, lisa.
Material examinado: Congonhas do Norte, caminho a Gouveia, $13 \mathrm{~km}$ NW de Congonhas do Norte, aprox. 18ㄴ1'S, 43ㄴ'W, M.M. Arbo et al. 5004, 13.II.1991, fr. (SPF); Serra Talhada, fazenda Vereda do Cambota, alto da Serra do João Camilo, 6,8 km sudoeste da estrada Congonhas do Norte Gouveia, entrada a 3,7 km noroeste de Congonhas do Norte, 1848'39"S, 4345'09"W, M.F. Calió et al. 25, 19.l.2004, fl. (SPF). Jaboticatubas, Serra do Cipó, G. Eiten \& L.T. Eiten 6765, 22.XI.1965, fl. (SP, SPF); idem, A. Furlan \& M.G. Sajo 6006 , 1.III.1980, fl. (SP, SPF); idem, rodovia Lagoa Santa Conceição do Mato Dentro - Diamantina, km 122, J. Semir \& M. Sazima CFSC 562, 14.XII.1971, fl. (SP, UEC). Santana do Riacho, rodovia Belo Horizonte - Conceição do Mato Dentro, km 117, perto do córrego Alto do Cupim, A. Furlan et al. CFSC 7211, 19.IV.1981, fl. (SPF).

Material adicional: Bahia: Andaraí, $7 \mathrm{~km}$ SW de Nova Redenção, caminho a Mucugê, aprox. 1246'S, 4111', M.M. Arbo et al. 5778, 25.XI.1992, fl. (SPF); Xique-Xique, próximo a Xique-Xique, 11066'S, 4243', M.L. Guedes et al. PCD 3029, 24.Vl.1996, fl., fr. (SPF).

Borreria verticillata ocorre por todo o Brasil (Barbosa et al. 2014), sendo encontrada na Serra do Cipó em campo arenoso, campo sujo e locais perturbados. Foi coletada com flores entre janeiro e abril.

4.9. Borreria warmingii K.Schum. in Mart., Eichler \& Urb., FI. bras. 6(6): 237. 1889.

Fig. 4. E.

Ervas eretas, pouco ramificadas acima da base, 30-40 cm alt.; râmulos cilíndricos, estriados, híspidos apenas nos vértices. Estípulas truncadas, conatas, diminutamente pilosas, $1-5 \times 3-6 \mathrm{~mm}$, laciniadas, 6-10 lacínios filiformes, 6-12 mm compr., persistentes. Folhas opostas, sésseis; lâmina linear, base atenuada, margem espessada, hispídula, ápice agudo, 30-55(-65) mm compr., 1,5-6(-12) mm larg., cartácea, concolor,olivácea quando seca, glabra a pilosa; venação acródroma, nervuras secundárias pouco conspícuas a inconspícuas na face abaxial, inconspícuas na face adaxial. Flores em glomérulos densos apicais (ocasionalmente axilares), subtendidos por 2-4 brácteas foliáceas ligeiramente alargadas; hipanto 3-5 $\mathrm{mm}$ compr., glabrescente a piloso, tubo curto, lacínios 4, agudos, com margens escariosas, ciliadas, 2-3 mm compr.; corola 5-7 mm compr., alva, tubo longo, lobos patentes a reflexos, 1,5-2 mm compr.; flores (protoginia não observada) com anteras 1-1,2 mm compr., azuis; estilete 6-7 mm compr., estigma capitado. Cápsulas 6-7 $\mathrm{mm}$ compr., obovoides, sésseis; epicarpo estrigoso, piloso ou glabrescente; endocarpo flexível, rompendo-se quando maduro; sementes elipsoides, 2,5 mm compr., com fenda adaxial.

Material examinado: Congonhas do Norte, Serra Talhada (setor nordeste da Serra do Cipó), 1850'33"S, 4345'32"W, J.R. Pirani et al. 5587, 19.I.2007, fl. (K, SPF). Jaboticatubas, Serra do Cipó, Estrada da Usina, A.B. Joly et al. CFSC 2220, 28.V.1972, fl. (SP); $10 \mathrm{~km}$ da entrada da estrada principal, A.B. Joly \& J. Semir CFSC 3023, 21.VIII.1972, fl. (SP); rodovia Lagoa Santa - Conceição do 
Flora da Serra do Cipó, Minas Gerais: Rubiaceae

Mato Dentro - Diamantina, estrada da Usina, A.B. Joly et al. CFSC 1224, 5.III.1972, fl. (SP); idem, km 110, P. Montouchet CFSC 4200, 2.V.1973, fl. (SP); idem, km 122, A.B. Joly et al. CFSC 1038, 5.III.1972, fl. (SP). Santana de Pirapama, acesso pela Faz. Inhame, Trilha da Senhorinha, D.C. Zappi et al. 1912A, 8.III.2009, fl. (K, RB, SPF); Faz. Inhame (Serra Mineira), aproximadamente 185' S, 435' W, J.R. Pirani et al. CFSC 8021, 21.III.1982, fl. (SPF); idem, J.R. Pirani et al. CFSC 8076, 22.III.1982, fl. (SPF); idem, I. Cordeiro et al. CFSC 8209, 24.III.1982, fl. (SPF). Santana do Riacho, 10 km NE Cardeal Mota na estrada para Conceição do Mato Dentro, 19²0'S, 4335'W, M.M. Arbo et al. 4669, 8.II.1991, fl., fr. (CTES, K, SPF); 10-20 km NE de Cardeal Mota, caminho a Conceição do Mato Dentro, $19^{\circ} 20^{\prime}$ S, $43^{\circ} 35^{\prime} \mathrm{W}$, M.M. Arbo et al. 4198, 15.V.1990, fl. (SPF); Parque Nacional da Serra do Cipó, trilha para Cachoeira da Farofa, 1921'13.6"S, 4337'7.5"W, C.L. Silva et al. 23, 27.VII.2006, fl. (SPF); estrada Lagoa Santa - Conceição do Mato Dentro, km 89, A.A. Conceição et al. CFSC 13976, 10.IV.1995, fl. (SPF); rodovia Belo Horizonte - Conceição do Mato Dentro, km 106, D.C. Zappi \& C. Kameyama CFSC 9633, 24.III.1986, fl. (SPF); Serra do Cipó, Vale da Mãe D'água, V.C. Souza \& C.M. Sakuragui 3381, 1.V.1993, fl. (ESA, K).

Material adicional: Minas Gerais: Brumadinho, Serra da Calçada (Serra da Moeda), Retiro das Pedras, 200' $\mathrm{S}$, 4413'W, L.A. Martens 396, 5.I.1990, fl. (SPF); Gouveia, estrada de terra para a fazendo do Sr. Everaldo, V.L. Scatena et al. CFCR 10444, 14.IV.1987, fl. (SPF); BR-259, 44 km SW

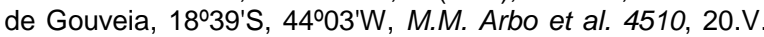
1990, fl. (SPF); Joaquim Felício, Serra do Cabral, ca. $15 \mathrm{~km}$ W de Joaquim Felício, caminho a Várzea da Palma, aprox.

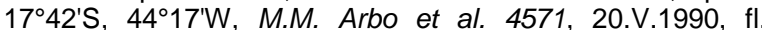
(SPF); Ouro Branco, estrada entre Ouro Branco e Morro do Gabriel, ca. $9 \mathrm{~km}$ de Ouro Branco, 20²9'20,6"S, 4339'49,1"W, V.C. Souza et al. 7932, 8.III.1995, fl. (SPF); Serra do Ouro Branco, 2028'S, 434' 'W, M.M. Arbo et al. 3935, 12.V.1990, fl. (SPF).

Borreria warmingii ocorre no Paraguai e Brasil, sendo encontrada no Distrito Federal, Goiás, Mato Grosso do Sul, Mato Grosso, Minas Gerais e São Paulo (Barbosa et al. 2014). Na Serra do Cipó, ocorre em campos arenosos, florescendo entre janeiro e agosto. Bacigalupo \& Cabral (2007a) distinguem $B$. warmingii K. Schum. e B. tenella (Kunth) Cham. \& Schltdl. pelos lacínios das estípulas, que seriam 6-10 de cada lado e todos iguais em $B$. tenella, enquanto em $B$. warmingii o lacínio mediano seria mais conspícuo e os lacínios laterais apareceriam em número menor. Entretanto, os materiais disponíveis no sítio da Lista do Brasil (www.floradobrasil.jbrj.gov.br) são muito semelhantes e representam extremos de uma gama de material examinado para o presente trabalho, no qual essas diferenças mostram-se gradativas. Infelizmente não foi possível localizar os materiais-tipo para esclarecer essa questão.

\subsection{Borreria sp.}

Subarbustos eretos, ramificados na base, ca. $40 \mathrm{~cm}$ alt.; ramos e râmulos cilíndricos ou levemente costados, não alados, densamente pilosos, tricomas estrigosos curtos, alvos. Estípulas semilunares, conatas, bainha 1,0-2,2 x 2,5-3,0 mm, laciniadas, 5-7 lacínios filiformes até $6 \mathrm{~mm}$ compr., persistentes.
Folhas opostas a falsamente verticiladas, sésseis; lâmina lanceolada a estreitamente elípticas, base atenuada, ápice agudo, 5-23 mm compr., 1,5-4 mm larg., coriáceas, discolores, face adaxial fosca, densamente estrigosa, face abaxial avermelhada, densamente estrigosa; venação eucamptótroma, nervuras secundárias subparalelas, salientes na face abaxial, inconspícuas na face adaxial. Flores em glomérulos densos apicais subtendidos por 4 brácteas foliáceas lanceoladas a estreitamente elípticas; hipanto 4,1 $\mathrm{mm}$ compr., estrigoso, tubo ausente, lacínios 4, agudos, 2,7 mm compr., ciliados; corola 5 $\mathrm{mm}$ compr., alva, tubo curto, lobos ereto-patentes, ca. $2 \mathrm{~mm}$ compr.; flores protogínicas, anteras $1,6 \mathrm{~mm}$ compr.; estilete até $5 \mathrm{~mm}$ compr., estigma globoso. Frutos não examinados.

Material examinado: Santana de Pirapama, Fazenda Inhame (Serra Mineira), aproximadamente 185' $\mathrm{S}, 43^{\circ} 54^{\prime} \mathrm{W}$, J.R. Pirani et al. CFSC 8075, 22.III.1982, fl. (SPF).

Este espécime coletado apenas em flor assemelha-se a $B$. capitata, porém apresenta porte menor e folhas coriáceas. Devido à ausência de frutos, não foi possível realizar a identificação da espécie.

\section{Chiococca P. Browne}

Trepadeiras apoiantes, arbustos a arvoretas; ramos não volúveis. Estípulas cuspidadas a espatuladas, persistentes. Folhas opostas, pecioladas, textura e pilosidade variável, com ou sem domácias. Inflorescências axilares a subterminais, em racemo ou panícula, secundifloras (com todas as flores voltadas para um mesmo lado); flores bissexuadas, actinomorfas, 4-5-meras, hipanto turbinado, laciniado; corola com prefloração valvar, amplamente infundibuliforme a tubulosa; estames 4-5, inseridos perto da base do tubo da corola, anteras lineares, inclusas ou exsertas; ovário geralmente bilocular, lóculos uniovulados, estigma inteiro. Drupas carnosas a coriáceas, ovoides, bi-globosas, alvas quando maduras; sementes pêndulas, comprimidas.

5.1. Chiococca alba (L.) Hitchc., Ann. Report Missouri Bot. Gard. 4: 94. 1893.

Fig. 2. C.

Arbustos eretos ou escandentes, 1-2 m alt.; ramos cilíndricos levemente estriados, diminutamente pubescentes a glabros. Estípulas subuladas, 2 x 1,5 $\mathrm{mm}$, pubescentes a glabras. Folhas opostas, pecioladas; pecíolo 2-5 $\mathrm{mm}$ compr.; lâmina largamente oval, lanceolada ou elíptica, base arredondada, margem plana a ligeiramente revoluta, ápice agudo a acutiúsculo, (2-)3-6 cm compr., (1,2-)2-3,5 cm larg., membranácea, levemente discolor, face abaxial levemente pubérula, face adaxial glabra a minutamente pubérula, às vezes brilhante; venação broquidódroma, nervuras salientes na face abaxial, 
impressas a inconspícuas na face adaxial, nervuras secundárias 4-5 pares, retículo inconspícuo a pouco conspícuo. Inflorescências racemosas ou paniculadas, axilares, ocultas pelas folhas, (3-)4-9(-20)-floras; flores pediceladas; brácteas lineares; hipanto globoso, com tubo constrito, lacínios 5, ovados; corola 5-lobada, 4-5 $\mathrm{mm}$ compr., 5-7 $\mathrm{mm}$ larg., infundibuliforme, esparsamente pubescente externamentemente, alva a amarela; estames 5, semi-inclusos; estilete inteiro, exserto. Drupas 4-8 x 4-8 mm, coroadas pelos restos do cálice persistentes, verde-claras passando a alvas e esponjosas quando maduras; sementes 2 , oblongas, comprimidas.

Material examinado: Santana de Pirapama, Serra do Cipó, Fazenda Toucan Cipó, proximidades do estábulo, 1900'15,1"S, 4346'34,4", W. Milliken et al. 4124, 19.XI.2009, fl. (K, RB, SPF); estrada para a captação, $683 \mathrm{~m}$, D.C. Zappi et al. 730, 15.II.2007, fr. (ESA, HUEFS, K, SPF); 1859'26"S, 4346'38"W, D.C. Zappi et al. 1834, 7.III.2009, fr. (K, RB, SPF).

Material adicional: Goiás: $60 \mathrm{~km} N$ de Corumbá de Goiás na estrada para Niquelândia, vale do Rio Maranhão, H.S. Irwin et al. 19076, 23.I.1968, fr. (K, NY, UB). Minas Gerais: Montezuma, $23 \mathrm{~km} \mathrm{NE}$ da cidade, 2045'38"S, 44³3'23"W, V.C. Souza et al. 5489, 14.III.1994, fl., fr. (K, $\mathrm{SPF}$ ); Morro do Ferro, $7 \mathrm{~km} \mathrm{~N}$ da cidade, $20^{\circ} 45^{\prime} 38^{\prime \prime S}$, 4433'23"W, V.C. Souza et al. 5085, 15.I.1994, fl. (K, SPF).

Chiococca alba é amplamente distribuída na Região Neotropical, desde o México até a Argentina, ocorrendo em todas as regiões do Brasil. Trata-se de uma espécie muito variável, sendo que a descrição acima baseou-se nos espécimes supracitados de Minas Gerais e de Goiás. A distinção entre $C$. alba e C. nitida Benth. é difícil, pois ambas apresentam características que se sobrepõem; mais estudos sobre a distribuição e morfologia desta última espécie são necessários para esclarecer se a mesma deve ser reconhecida. Na Serra do Cipó, C. alba foi coletada com flores em novembro e em fruto em fevereiro e março.

\section{Chomelia Jacq.}

Arbustos a árvores; ramos cilíndricos, apresentando ramificação bifurcada, com entrenós de extensão distintos, ramos velhos frequentemente transformados em espinhos. Estípulas inteiras, triangulares, persistentes. Folhas opostas, muitas vezes reunidas no ápice dos ramos curtos, pecioladas, domácias às vezes presentes. Flores bissexuadas, actinomorfas, 5-meras, em inflorescências subterminais escorpioides; hipanto turbinado, com tubo pouco desenvolvido, laciniado a denteado; corola com prefloração valvar, tubulosa, até duas vezes mais longa que o cálice; estames 5 , epipétalos; ovário bilocular, óvulos pêndulos. Drupas 2-seminadas; pericarpo carnoso ou coriáceo, verde, acastanhado, vermelho, vináceo ou amarelo; pirênios oblongos.

Chave para as espécies

1. Arbusto inerme até $1 \mathrm{~m}$ alt., folhas distribuídas no ápice dos ramos; corola até $5,5 \mathrm{~mm}$ compr., alva a creme-amarelada 6.2. C. ribesioides

1'. Arbustos a arvoretas com ramos espinescentes, 2-4 m alt., folhas distribuídas uniformemente ao

longo dos ramos; corola 8-10 mm compr., rosada a vinácea 6.1. C. obtusa

6.1. Chomelia obtusa Cham. \& Schltdl., Linnaea 4: 185.1829.

Fig. 2. D-E.

Arbusto a arvoreta, 2-4 m alt.; ramos laterais às vezes transformados em espinhos, casca castanhoacinzentada, râmulos esparsamente vilosos. Estípulas triangulares, 1 × 1,5 mm, acumuladas nas extremidades dos ramos, ligeiramente pubescentes. Folhas opostas, espaçadas ao longo dos ramos, pecioladas; pecíolo 1-4 mm compr.; lâmina largamente oval, orbicular ou oboval, base arredondada a atenuada, ápice arredondado a mucronado, às vezes acuminado, 0,8-5 cm compr., 0,8-3 cm larg., cartácea, discolor, face abaxial glabra ou glabrescente, secando verde-clara, face adaxial glabra, secando verde a verde-oliváceo escura; venação broquidódroma, nervuras impressas a inconspícuas em ambas as faces, secundárias 3-4(-5) pares, retículo inconspícuo, domácias presentes. Inflorescências dicasiais axilares, 2-4-floras; pedúnculos delicados, 1-2 cm compr.; brácteas lineares; flores sésseis; hipanto estreitamente turbinado, $2 \times 0,5 \mathrm{~mm}$, tubo curto, lacínios 4, espatulados; corola 4-lobada, 8-10 mm compr., estreitamente tubular, esparsamente pubescente externamente, pubérula internamente, rosada a vinácea; estames 4, semi-inclusos. Drupas estreitamente elipsoides ou cilíndricas, 8-10 mm compr., 2-3 mm diâm., coroadas pelos restos do perianto, pericarpo liso, verdes passando a atropurpúreas quando maduras; pirênios ósseos, levemente costelados, ca. $6 \mathrm{~mm}$ compr.

Material examinado: Santana de Pirapama, Serra do Cipó, acesso pela Faz. Inhame, povoado de Inhame,

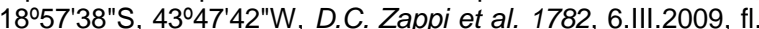
(K, RB, SPF). Santana do Riacho, Serra do Cipó, acesso pela Fazenda Inhame, Capela de São José, 1858'36"S, 4346'54"W, D.C. Zappi et al. 2194, 16.III.2009, fl., fr.(K, RB, SPF); Cardeal Mota, sede da fazenda Monjolos, $K$ Yamamoto \& L.S. Kinoshita 02/76, 24.IX.2002, fl (UEC). 
Flora da Serra do Cipó, Minas Gerais: Rubiaceae

Material adicional: Minas Gerais: Barroso, Mata do Baú, L.C. Assis \& M.K. Ladeira 380, 25.XI.2001, fl. (CESJ, K); Curvelo, E. Tameirão Neto 3166, 25.V.2000, fl. (BHCB, K); São João da Chapada, $15 \mathrm{~km}$ da cidade, H.S. Irwin et al. 28129, 23.III.1970, fl. (K, NY, UB). Tocantins: $50 \mathrm{~km}$ de Arraias na estrada para Conceição do Tocantins, $12^{\circ} 39^{\prime} \mathrm{S}$, $47^{\circ} 06^{\prime} \mathrm{W}$, J.A. Ratter et al. 8140, 23.XI.1998, fl., fr. (E, K).

Espécie de ampla distribuição, C. obtusa ocorre no Paraguai, na Bolívia e no Brasil, com registros no Tocantins, Maranhão, Pernambuco, Bahia, Mato Grosso, Goiás, Distrito Federal, São Paulo, Minas Gerais, Rio de Janeiro, Paraná e Rio Grande do Sul (Barbosa et al. 2014, Govaerts 2013). Na Serra do Cipó, foi coletada em mata ciliar do Rio Cipó e em mata seca semidecidual, a baixas altitudes, florescendo e frutificando em fevereiro e março.

6.2. Chomelia ribesioides Benth. ex A. Gray, Proc. Am. Acad. 4: 38. 1860.

Fig. 2. F.

Arbusto 0,8-1 m alt.; ramos inermes, com casca castanho-acinzentada e lenticelas claras, alongadas, râmulos glabros. Estípulas triangulares, $4 \times 5 \mathrm{~mm}$, seríceas passando a glabrescentes. Folhas opostas, agregadas no ápice de ramos curtos, pecioladas; pecíolo 5-8 $\mathrm{mm}$ compr.; lâmina largamente oboval a orbicular, às vezes romboide, base atenuada a arredondada, ápice arredondado a acutiúsculo, 4-9 cm compr., 3-6 cm larg., cartácea, discolor, face abaxial velutina, secando verde-clara, face adaxial tomentosa a glabrescente, secando verde a verde-oliváceo escura; venação eucamptódroma, nervuras secundárias 6-7 pares, saliente na face abaxial, impressas na face adaxial, retículo inconspícuo, domácias ausentes. Inflorescências dicasioides axilares (3-)4-6(-8)-floras; flores sésseis; brácteas lineares; hipanto turbinado a obovoide, tubo ausente, lacínios 4, triangulares; corola 4-lobada, 4-5,5 mm compr., infundibuliforme, esparsamente pubescente externamente, pubérula internamente, alva a cremeamarelada; estames 4, semi-inclusos. Drupas elipsoides a subcilíndricas, 6-8 mm compr., 4-6 mm diâm., pericarpo estriado, verdes passando a amarelas quando maduras; pirênios ósseos, amarelados, costelados, ca. $5 \mathrm{~mm}$ compr.
Material examinado: Jaboticatubas, Serra do Cipó, Rodovia Belo Horizonte - Conceição do Mato Dentro, $19^{\circ} 20^{\prime} 31,8^{\prime \prime S}, 43^{\circ} 38^{\prime} 37,8^{\prime \prime W}$, J.R. Pirani \& I. Cordeiro 5052, 6.III.2002, fr. (K, SPF); idem, km 117, M.S.F. Silvestre 9063, 3.XI.1978, fl. (UEC). Santana de Pirapama, Serra do Cipó, acesso pela Fazenda Inhame, E.S. Cândido et al. 529, 20.III.2011, fr. (SPF); estrada Santana de Pirapama Santana do Riacho, Fazenda Toucan Cipó, estrada da captação, $19^{\circ} 00^{\prime} 22^{\prime \prime S}, 43^{\circ} 45^{\prime} 20 " W$, D.C. Zappi et al. 801, 16.II.2007, fr. (ESA, K); trecho de São José da Cachoeira Inhame, Cachoeira Bonita, $18^{\circ} 58^{\prime} 40^{\prime \prime S}, 43^{\circ} 46^{\prime} 35^{\prime \prime W}$, V.C. Souza et al. 32642, 18.II.2007, fr. (ESA, K, SPF).

Material adicional: Minas Gerais, $30 \mathrm{~km}$ NE de Francisco Sá, H.S. Irwin et al. 22981, 10.II.1969, fr. (K, NY, UB). Joaquim Felício, Serra do Cabral, M.C.H. Mamede et al. CFCR 6356, 23.XI.1984, fr. (K, SPF).

Chomelia ribesioides ocorre na Bolívia e no Brasil, nos estados de Minas Gerais, Goiás, Distrito Federal e Bahia. É uma espécie decídua, encontrada a baixas altitudes na Serra do Cipó, em cerrados e orla de matas semideciduais. Durante o início da estação chuvosa, quando esta espécie floresce, as folhas novas são tomentosas, tornando-se glabrescentes na face abaxial na maturidade. $\mathrm{Na}$ região, foi coletada com flores em novembro, e com frutos em fevereiro e março.

\section{Coccocypselum P. Browne}

Ervas geralmente rasteiras, enraizando a partir de ramos decumbentes, perenes, geralmente indumentadas. Estípulas lineares, persistentes. Folhas opostas, pecioladas ou sésseis. Inflorescências axilares, cimeiras glomeruladas, pedunculadas ou sésseis, 1-20-floras. Flores bissexuadas, actinomorfas, heterostílicas, 4(5)-meras, sésseis; hipanto verde, com lobos lanceolados a triangulares, persistentes no fruto; corola com prefloração valvar, infundibuliforme, alva, rosada ou lilás, internamente indumentada no terço proximal, glabra a esparsamente indumentada nas demais regiões; ovário pluriovulado, com disco nectarífero no ápice; estilete glanduloso, estigma bífido, papiloso. Bagas alvas quando imaturas, azuis a violáceas quando maduras, internamente alvas, globosas ou oblongas, multisseminadas; sementes orbiculares, plano-convexas, pequenas, diminutamente muricadas.

1. Folhas sésseis ou curto-pecioladas, pecíolo até $4 \mathrm{~mm}$ compr., margem revoluta .................................. 7.5. C. pedunculare

1 '. Folhas pecioladas, pecíolo igual ou maior do que $6 \mathrm{~mm}$ compr., margem plana.

2. Ramos e folhas hirsutos, tricomas eretos ................................................................................7.4. C. hasslerianum

2'. Ramos e folhas glabros ou seríceos, tomentosos, velutinos, vilosos, tricomas, quando presentes, adpressos ou eretos.

3. Folhas com ambas as faces glabras a esparsamente indumentadas, 4-6 pares de nervuras; estípulas até $4 \mathrm{~mm}$ compr.

3'. Folhas com ambas as faces ou pelo menos uma delas densamente indumentada, 7 ou mais pares de nervuras; estípulas maiores do que $6 \mathrm{~mm}$ compr. 
4. Planta não ramificada; face adaxial das folhas glabras a esparsamente indumentadas com tricomas concentrando-se sobre as nervuras, ápice acuminado; inflorescências multifloras (16 flores ou mais)

4'. Planta bastante ramificada; face adaxial das folhas densamente indumentada por toda a superfície, ápice agudo; inflorescências paucifloras (até 9 flores)

7.1. Coccocypselum aureum (Spreng.) Cham. \& Schltdl., Linnaea 4: 139 (1829).

Fig. 5. F.

Erva prostrada, muito ramificada; caule e ramos cilíndricos, velutinos a tomentosos, entrenós 8$27 \mathrm{~mm}$ compr. Estípulas lineares, 6-9(-12) $\mathrm{mm}$ compr., 0,5-1 $\mathrm{mm}$ larg., velutinas a tomentosas. Folhas pecioladas; pecíolo 6-18 $\mathrm{mm}$ compr., ca. $2 \mathrm{~mm}$ diâm.; lâmina lanceolada a oval (raramente largamente oval), estreito-elíptica a elíptica, base atenuada a oblíqua, margem plana, ciliada, ápice agudo, 23-60 mm compr., 12-25(-35) mm larg., membranácea, concolor a discolor, face abaxial verde-clara, velutina a densoserícea, face adaxial verde-olivácea, tomentosa; venação eucamptódroma, nervuras secundárias 7-11 pares, proeminentes e densamente velutinas a seríceas na face abaxial, pouco conspícuas na face adaxial. Inflorescências 7-9-floras, sésseis ou pedunculadas, pedúnculo 10-40 $\mathrm{mm}$ compr., velutino a tomentoso; hipanto turbinado, 1,4-2,0 mm compr., 1,5$1,8 \mathrm{~mm}$ diâm., seríceo, lacínios estreitamente triangulares, ápice acuminado, 2,3-4,0 mm compr., $0,7-0,8 \mathrm{~mm}$ larg., ambas as faces velutinas a tomentosas; corola alva com lobos lilases, $6,5-9 \mathrm{~mm}$ compr., 1,5-2,0 mm larg. na base, externamente tomentosa, lobos triangulares, ápice agudo, 3,0-3,8 $\mathrm{mm}$ compr., 1,8-2,5 mm larg.; filetes 1,2-4,0 mm compr., anteras 1,2-1,5 mm compr.; estilete 1,2-2,5 $\mathrm{mm}$ compr., estigma 1,3-1,5 mm compr. Bagas, alvas a azuis, obovoides a elipsoides, $12-20 \mathrm{~mm}$ compr., 10$15 \mathrm{~mm}$ larg. vilosas; sementes 1,5-2 mm diâm.

Material examinado: Congonhas do Norte, Serra da Carapina (Serra Talhada na Folha do IBGE) setor N da Serra do Cipó, 1852'12"S, 4344'14"W, J.R. Pirani et al. 4117, 2.III.1998, fr. (SPF). Jaboticatubas, Serra do Cipó, rodovia Lagoa Santa - Conceição do Mato Dentro - Diamantina, km 112, J. Semir \& M. Sazima CFSC 573, 14.XII.1971, fl. (SP, UEC); idem, km 114, A.B. Joly et al. CFSC 1601, 15.IV.1972, fl., fr. (SP); idem, km 115, A.B. Joly et al. CFSC 778, 4.III.1972, fl., fr. (SP); idem, km 116, A.B. Joly et al. CFSC 183, 6.VI.1970, fl. (SP); idem, km 126, A.B. Joly et al. CFSC 4656, 20.X.1973, fl., fr. (SP); idem, km 127, J. Semir \& M. Sazima CFSC 512, 13.XII.1971, fl. (SP, UEC); idem, km 128, A.B. Joly et al. CFSC 1118, 5.III.1972, fr. (SP); idem, km 139, A.B. Joly et al. CFSC 1900, 14.IV.1972, fl. (SP, UEC). Santana de Pirapama, Serra do Cipó, acesso pela Fazenda Inhame, E.S. Cândido et al. 533, 20.III.2011, fr. (SPF); 1855'14"S, 4347'22"W, D.C. Zappi \& N.P. Taylor 2211, 21.VII.2009, fr. (K, SPF). Santana do Riacho, Serra do Cipó, Ribeirão Indequicé, próxima a estrada da Usina, $R$. Simão et al. CFSC 9467, 14.XII.1985, fl. (SPF); km 107 caminho para Usina Dr. Pacífico Mascarenhas, E. Forero et al. 7938 [CFSC 8851], 7.IX.1980, fr. (SP); km 123, estrada da Usina, Fazendo do Sr. Cornelio, J. Diacui et al. CFSC 9076, 24.X.1982, fl., fr. (SPF); Parque Nacional da Serra do Cipó, próximo a estátua do Juquinha, E.A. Anunciação 221, 2.V.1993, fr. (SP); Serra da Bandeirinha, I. Cordeiro et al. CFSC 10581, 10.IX.1987, fl., fr. (SPF); idem, A.M. Giulietti et al. CFSC 12504, 27.VII.1991, fl. (SPF); Rodovia Belo Horizonte - Conceição do Mato Dentro, km 110 (antigo km 114), J.R. Pirani \& C. Kameyama CFSC 12915, 23.IV.1992, fr. (SPF); idem, km 125, Alto do Palácio, M.T.V.A. Campos et al. CFSC 12893, 7.III.1992, fl., fr. (SPF); idem, km 126 antigo, N.L. Menezes et al. CFSC 11104, 1.V.1988, fr. (SPF); 7-12 km N de Santana do Riacho, camino a Lapinha, 1910'S, 4341'W, M.M. Arbo et al. 4884, 11.Il.1991, fr. (SPF); $10-20$ km NE de Cardeal Mota, camino a Conceição do Mato Dentro, 1920'S, 43ํㅜㄴ'W, M.M. Arbo et al. 4118, 15.V.1990, fr. (SPF).

Coccocypselum aureum apresenta ampla distribuição, ocorrendo nas Américas Central e do Sul (Costa 2004). No Brasil, é encontrada nos estados de Minas Gerais, Rio de Janeiro, São Paulo, Distrito Federal, Goiás, Mato Grosso, Mato Grosso do Sul, Bahia, Pernambuco, Alagoas, Roraima e Tocantins (Barbosa et al. 2014). Na Serra do Cipó, habita em locais sombreados e úmidos, às margens de riacho, na orla de matas ciliares ou campos brejosos. Nessa região, foi coletada com flores e frutos em março, outubro e novembro, apenas flores em julho e dezembro e apenas flores de fevereiro a julho. Caracteriza-se pelo indumento velutino a tomentoso bastante denso e folhas frequentemente esverdeadas quando secas.

7.2. Coccocypselum condalia Pers., Syn. PI. 1: 132. 1805.

Fig. 5. G-H.

Erva prostrada, não ramificada; caule cilíndrico, estriado, esparsamente viloso ao longo dos entrenós, densamente viloso próximo aos nós, entrenós 12-43 $\mathrm{mm}$ compr. Estípulas lineares, 3,5-4 mm compr., 0,10,2 mm larg., vilosas. Folhas pecioladas; pecíolo 7-12 mm compr., 0,5-0,6 mm diâm.; lâmina oval, base atenuada, margem plana, ciliada, ápice agudo, 19-37 mm compr., 9-16 mm larg., membranácea, concolor, ambas as faces glabras a esparsamente estrigosas; venação eucamptódroma, nervuras secundárias 4-6 pares, levemente proeminentes ou levemente impressas, proeminentes e densamente vilosas na superfície abaxial, esparsamente vilosas na superfície adaxial. Inflorescências 7-8-floras, pedunculadas; pedúnculo 10-40 mm compr., viloso; hipanto turbinado, 1,0-2,0 mm compr., 1,1-1,4 mm diâm., viloso, lacínios estreitamente triangulares ou oblongos, ápice agudo a acuminado, 2,5-3,0 mm compr., 0,7-1,2 mm larg., face abaxial vilosa, face adaxial glabra; corola alva com fauce e lobos lilases, 10,5-15 mm compr., 1,2-1,3 mm larg. na base, vilosa externamente, lobos triangulares 


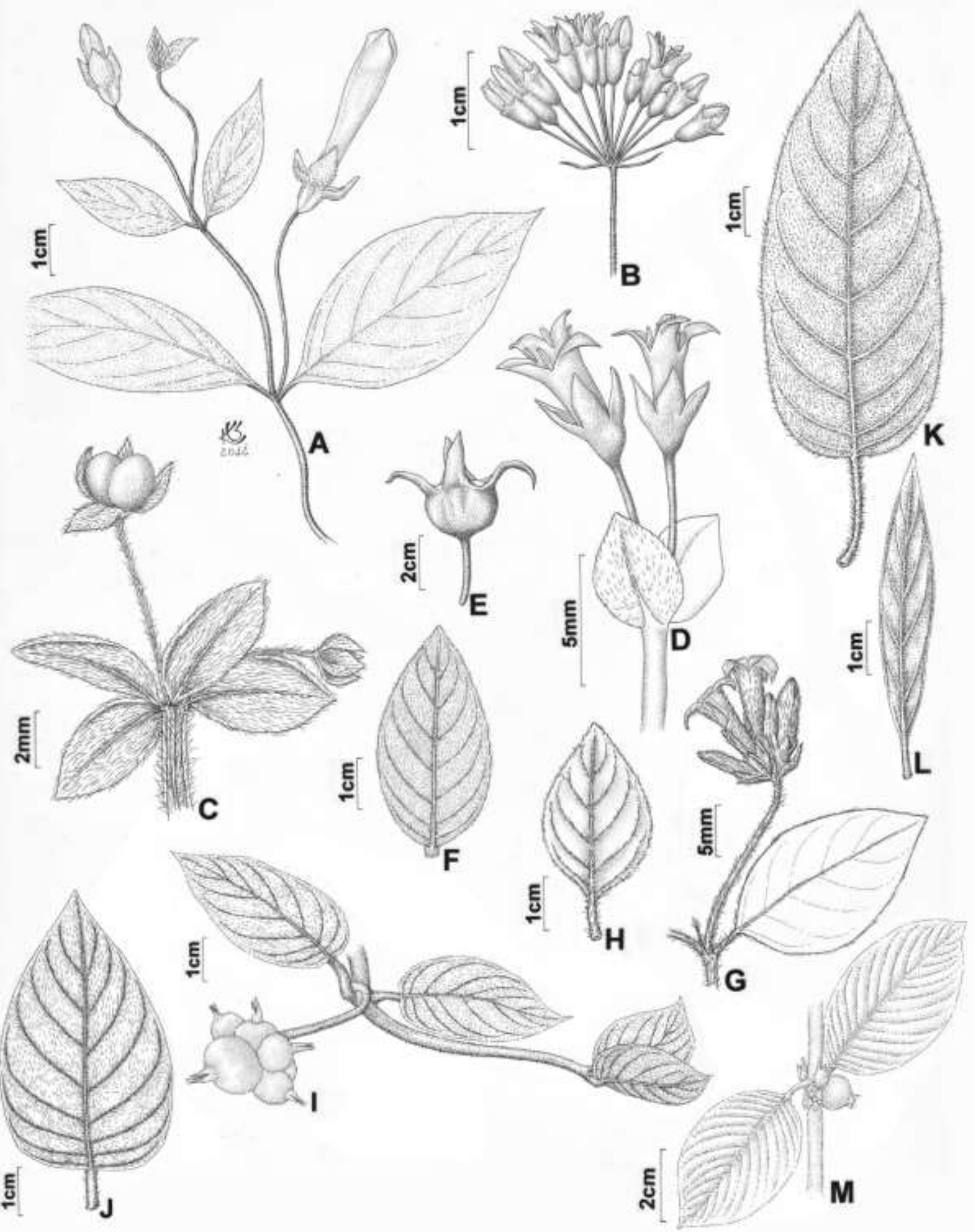

Fig. 5 - Trepadeiras e plantas decumbentes. A. Manettia cordifolia, Hábito. B. Emmeorhiza umbellata, Infrutescência jovem. C. Galium noxium, Ramo com frutos. D-E. Oldenlandia salzmannii. D. Ramo com flores. E. Fruto. F. Coccocypselum aureum, Folha, face adaxial. G-H. Coccocypselum condalia. G. Inflorescência, H. Folha, face abaxial. I-J. Coccocypselum erythrocephalum. I. Hábito com frutos. J. Folha, face adaxial. K. Coccocypselum hasslerianum, Folha, face abaxial. L. Coccocypselum pedunculare, Folha, face abaxial. M. Sabicea brasiliensis, Detalhe do ramo. (A: Zappi 2287. B: Krieger 10674. C: Anderson 35254. D-E: Harley 18002. F: Zappi 2211. G-H: Mota 1977. I-J: Zappi 1894A. K: Souza 32647. L: Mota \& Viana 1960. M: Zappi 1731). 
a largamente deltados, ápice agudo, 2,8-5,5 mm compr., 2,0-2,7 mm larg.; filetes $1,5-2,5$ ou ca. $0,5 \mathrm{~mm}$ compr., anteras 2,0-2,2 ou ca. 1,35 mm compr.; estilete ca. 2,0 ou ca. 10,5 mm compr., estigma 0,9-1,9 ou ca. 2,35 mm compr. Bagas, alvas a azuis, ovoides, 12-20 mm compr., 7-10 $\mathrm{mm}$ larg., glabras a esparsamente vilosas; sementes 2-3 mm diâm.

Material examinado: Santana do Riacho, Serra do Cipó, $2 \mathrm{~km}$ acima da entrada para a estrada da Usina, $R$. Simão CFSC 10435, 6.IX.1987, fl. (SPF).

Material adicional: Minas Gerais: Camanducaia, Monte Verde, R. Simão-Bianchini 316, 3.VI.1992, fl., fr. (SPF); Vila de Monte Verde, R. Simão-Bianchini 328, 3.VI.1992, fl., fr. (SPF); Catas Altas, Serra do Caraça, R.C. Mota 1977, 18.XII.2002, fl. (BHCB, K); Lima Duarte, Parque Estadual do Ibitipoca, R.C. Forzza et al. 4217, 1.VII.2006, fr. (SPF, RB); São Tomé das Letras, Serra de São Tomé, I. Cordeiro et al. CFCR 5692, 30.X.1984, fl. (SPF); São Paulo, Cunha, Parque Estadual da Serra do Mar, núcleo CunhaIndaiá, R. Mello-Silva et al. 1793, 25.III.2000, fl., fr. (SPF); Pindamonhangaba, L. Rossi et al. 1428, III.1994, fl., fr. (ESA, HRCB, SP, SPF, UEC); São José do Barreiro, estrada de São José do Barreiro para Silveiras, campos da Bocaina, $P$. Fiaschi et al. 225, 17.IV.2000, fr. (SP, SPF).

Coccocypselum condalia é uma espécie de ampla distribuição, ocorrendo nas Guianas, Venezuela, Equador, Peru e Paraguai (Costa 2004). No Brasil, foi coletada nos estados do Paraná, Rio Grande do Sul, Santa Catarina, Espírito Santo, Minas Gerais, Rio de Janeiro, São Paulo, Goiás, Mato Grosso, Mato Grosso do Sul, Bahia, e Tocantins (Barbosa et al. 2014). Na Serra do Cipó, foi coletada em local úmido, próximo a riacho, com flores em setembro. Caracteriza-se pelas folhas delicadas, glabras a esparsamente estrigosas, com tricomas concentrados sobre as nervuras.

7.3. Coccocypselum erythrocephalum Cham. \& Schltdl., Linnaea 4: 144. 1829.

Fig. 5. I-J.

Erva prostrada, não ramificada; caule e ramos cilíndricos, estriados, vilosos, entrenós (50-)100-150 $\mathrm{mm}$ compr. Estípulas lineares, 6-8 mm compr., 0,1-0,3 $\mathrm{mm}$ larg., vilosas. Folhas pecioladas; pecíolo 9-13 mm compr., 1,5-2,0 mm diâm.; lâmina oval a elíptica, base arredondada, oblíqua ou cordiforme, margem plana, ciliada, ápice acuminado, 48-87 mm compr., 22-47 mm larg., membranácea, discolor, face abaxial verdeoliváceo clara, vilosa, face adaxial amarronzada, glabra a esparsamente estrigosa; venação eucamptódroma, nervuras secundárias 8-10 pares, proeminentes e densamente vilosas na superfície abaxial, impressas e vilosas na superfície adaxial. Inflorescências 16-23-floras, pedunculadas; pedúnculo (9-)17-35 mm compr., viloso; hipanto turbinado, 1,22,2 mm compr., 1,2-1,5 mm diâm., seríceo, lacínios estreitamente triangulares a triangulares, ápice acuminado, 2,0-4,0 mm compr., 0,5-0,6 mm larg., face abaxial vilosa, face adaxial glabra ou esparsamente vilosa próximo ao ápice; corola alva com fauce e lobos lilases, 5,5-7 mm compr., 1,0-1,3 mm larg. na base, externamente glabra no terço proximal e vilosa apicalmente, lobos triangulares, ápice agudo, 2,5-3,0 $\mathrm{mm}$ compr., 1,0-1,5 mm larg.; filetes $1,5-2,0$ ou $0,5-$ $0,75 \mathrm{~mm}$ compr., anteras $1,7-1,8$ ou $0,95-0,1 \mathrm{~mm}$ compr.; estilete $0,8-1,4$ ou 4,0-4,5 mm compr., estigma $0,5-0,6$ ou ca. $1,0 \mathrm{~mm}$ compr. Bagas, alvas a azuis, ovoides a elipsoides, 8-10 mm compr., 5-6 mm larg., esparsamente vilosas; sementes 1,5-1,9 mm diâm.

Material examinado: Jaboticatubas, Serra do Cipó, rodovia Lagoa Santa - Conceição do Mato Dentro Diamantina, km 126, M.S.F. Silvestre et al. 9066, 2.XI.1978, fl. (UEC); idem, A.B. Joly et al. 4656, 20.X.1973, fl., fr. (SP, UEC); idem, km 129, A.B. Joly et al. CFSC 4609, 20.X.1973, fl. (SP); idem, km 136, M.S.F. Silvestre et al. 8983, 2.XI.1978, fl. (UEC). Santana do Riacho, km 107, estrada para Usina Dr. Pacífico Mascarenhas, E. Forero et al. 8027 [CFSC 8940], 7.IX.1980, fl. (SP); estrada Lagoa Santa a Conceição do Mato Dentro, km 109 (antigo 114) E. Forero et al. 7750 [CFSC 8675], 6.XI.1980, fl. (SP); rodovia Belo Horizonte - Conceição do Mato Dentro, km 121, córrego Três Pontinhas, J.R. Pirani \& L. Rossi CFSC 9194, 13.XI.1983, fl., fr. (SPF); Parque Nacional da Serra do Cipó, junto à sede do IBAMA do Alto do Palácio, J.R. Pirani et al. CFSC 12285, 27.IV.1991, fl., fr. (SPF).

Material adicional: Minas Gerais: Catas Altas, Serra do Caraça, trilha do Pico do Carapuça, ca. $20^{\circ} 05^{\prime} \mathrm{S}, 43^{\circ} 30^{\prime} \mathrm{W}$, A. Rapini \& M.L. Kawasaki 696, 1.XII.1998, fl., fr. (SPF); Ouro Preto, Serra das Lavras Novas, sul de Ouro preto, Estrada Real, ca. $1 \mathrm{~km}$ da pousada Canto da Serra (localidade de Venda do Campo), M. Groppo Jr. \& M. Ulwin 678, 27.III.2001, fr. (SPF); Rio de Janeiro, Santa Maria Madalena, subida da Pedra Dubois, 2156'36-42"S, 41-59'29-33"W, C.B. Costa et al. 226, 22.XI.1999, fl., fr. (SPF).

Coccocypselum erythrocephalum é endêmica do Brasil, sendo encontrada nos estados da Bahia, Goiás, Espírito Santo, Minas Gerais, Rio de Janeiro e São Paulo (Barbosa et al. 2014). Na Serra do Cipó, é encontrada em local úmido, na orla de mata, tendo sido coletada com flores e frutos em abril e novembro. Caracteriza-se pelas folhas com face abaxial desamente indumentada e face adaxial glabra a esparsamente indumentada principalmente sobre as nervuras.

7.4. Coccocypselum hasslerianum Chodat, Bull. Herb. Boissier, II, 4: 169. 1904.

Fig. 5. K.

Erva prostrada, ramificada; caule e ramos cilíndricos, estriados, hirsutos, entrenós 45-145 mm diâm. Estípulas lineares, 5-7 mm compr., 0,3-0,4 mm larg. hirsutas. Folhas pecioladas; pecíolo 7-26 mm compr., 1,0-1,5 mm diâm.; lâmina oval a largamente oval, base oblíqua ou cordiforme (mais frequente), margem plana, ciliada, ápice acuminado, 40-96 mm compr., 25-56 mm larg., membranácea, ambas as faces concolores, secando amrronzadas, hirsutas; venação eucamptódroma, nervuras secundárias 5-10 pares, proeminentes e hirsutas na superfície abaxial, levemente proeminentes e hirsutas na superfície 
adaxial. Inflorescências 8-9-floras, sésseis, raramente curto-pedunculadas; pedúnculo 0,2-0,5 mm compr., hirsuto; hipanto turbinado, 1,5-2 mm compr., ca. 1,5 $\mathrm{mm}$ larg., hirsuto, lacínios estreitamente triangulares, ápice acuminado, 3,0-4,0 mm compr., 1-1,5 mm larg., face abaxial hirsuta, face adaxial glabra; corola alva, fauce e lobos lilases, 5,5-7,3 mm compr., 1,1-1,9 mm larg. na base, externamente hirsuta, lobos triangulares, ápice agudo, 2-3 mm compr., 1-2 mm larg.; filetes 1,5-2,0 mm compr., anteras 1,0-1,2 mm compr.; estilete 0,8-1,1 mm compr., estigma 1-1,5 mm compr. Bagas alvas a azuis, ovoides a elipsoides, 6-20 $\mathrm{mm}$ compr., 6-10 mm larg., glabras a esparsamente hirsutas; sementes ca. 1,5 mm diâm.

Material examinado: Santana do Riacho, Serra do Cipó (Serra da Lapa), estrada São José da Cachoeira Santana do Riacho, subida da trilha do João Carrinho, $19^{\circ} 0408 S$, $43^{\circ} 7387$ W, V.C. Souza et al. 32647, 18.II.2007, fr. (ESA, K); trecho de São José da Cachoeira - Inhame, Cachoeira Bonita, $18^{\circ} 58^{\prime} 40^{\prime}$ S, $43^{\circ} 46^{\prime} 35^{\prime \prime W}$, V.C. Souza et al. 32611, 18.II.2007, fl., fr. (ESA, K); rodovia Belo Horizonte Conceição do Mato Dentro, Alto do Palácio, R. SimãoBianchini \& S. Bianchini CFSC 12787, 2.VI.1991, fr. (SPF).

Material adicional: Bahia: Barro Preto, Serra da Pedra Lascada, 13,7 km de Barro Preto, na estrada que passa pela Fazenda São Miguel em direção à serra, 1446'13"S, 39³2'10"W, J.G. Jardim et al. 4779, 10.XII.2005, fl. (SPF). Rio de Janeiro: Santa Maria Madalena, Parque Estadual do Desengano, trilha para a Pedra do Desengano, $P$. Fiaschi et al. 1010, 25.III.2002, fr. (RB, SP, SPF). São Paulo: São Paulo, Água Funda, nativa no Jardim Botânico, O. Handro 2188, 22.XII.1971, fl., fr. (SPF).

Coccocypselum hasslerianum ocorre na Argentina, Brasil, Bolívia e Paraguai (Costa 2004), sendo encontrada no Brasil nos estados do Paraná, Rio Grande do Sul, Santa Catarina, Espírito Santo, Minas Gerais, Rio de Janeiro, São Paulo, Distrito Federal, Goiás, Mato Grosso, Alagoas e Bahia (Barbosa et al. 2014). Na Serra do Cipó, foi coletada em mata ciliar, próximo a riacho, com flores e frutos em fevereiro e apenas frutos em julho. Trata-se de uma planta inteiramente hirsuta, com folhas frequentemente cordadas na base.

7.5. Coccocypselum pendunculare Cham. \& Schltdl., Linnaea 4: 142. 1829.

Fig. 5. L.

Erva prostrada, ramificada; caule e ramos cilíndricos, estriados, estrigosos, entrenós 8-47 mm compr. Estípulas lineares, 4-10 mm compr., 0,3-1,0 $\mathrm{mm}$ larg., hirsutas. Folhas sésseis a curto-pecioladas; pecíolo (0-)2-4 mm compr., ca. $2 \mathrm{~mm}$ diâm.; lâmina estreitamente elíptica ou lanceolada, base atenuada a longamente atenuada, margem revoluta, ciliada, ápice acuminado, 31-61 mm compr., 6-15 mm larg., cartácea, ambas as faces estrigosas; venação eucamptódroma, nervuras secundárias 5-7 pares, proeminentes e denso-estrigosas na superfície abaxial, levemente proeminentes e denso-estrigosas na superfície adaxial. Inflorescências 10-14-floras, pedunculadas; pedúnculo (15-)18-58 mm compr., denso-estrigoso; hipanto obcônico, 1,75-3,0 mm compr., 1,5-2,0 $\mathrm{mm}$ diâm., seríceo, lacínios estreitamente triangulares, ápice acuminado, 2,25-2,5 $\mathrm{mm}$ compr., 0,45-1,0 mm larg., seríceos na face abaxial, glabros na face adaxial, com poucos tricomas apenas na porção apical; corola alva, fauce e tubo lilases, 7,5-8 mm compr., 1,2-1,3 mm larg. na base, serícea externamente, lobos estreitamente triangulares a triangulares, ápice agudo, 3,0-3,5 mm compr., 1,0-1,6 mm larg.; filetes $1,5-2,0$ ou ca. $0,5 \mathrm{~mm}$ compr., anteras 2,2-2,5 ou ca. $1,0 \mathrm{~mm}$ compr.; estilete $1,5-1,75$ ou ca. $6,5 \mathrm{~mm}$ compr., estigma $1,0-1,2$ ou ca. $1,7 \mathrm{~mm}$ compr. Bagas (Rossi et al. CFCR 2993) azuis, globosas, ca. $11 \mathrm{~mm}$ compr., ca. $10 \mathrm{~mm}$ larg., esparsamente estrigosas; sementes ca. 2,0 mm diâm.

Material examinado: Jaboticatubas, Serra do Cipó, rodovia Lagoa Santa - Conceição do Mato Dentro Diamantina, km 128, N. Menezes CFSC 4239, 11.VII.1973, fl. (SP, SPF, UEC). Santana do Riacho, Morro do Breu, 1904'20"-05'20"S, 4339'20"-40'20"W, N. Hensold CFSC 8546, 16-17.II.1982, fl. (SPF); Rodovia Belo Horizonte Conceição do Mato Dentro, km 132, Serra da Salitreira, Parque Nacional da Serra do Cipó, próximo à sede, $C$. Kameyama et al. CFSC 10405, 12.VII.1987, fl. (SPF).

Material adicional: Minas Gerais: Conceição do Mato Dentro, Parque Natural Municipal de Ribeirão do Campo, 1905'23"S, 4335'38"W, R.C. Mota \& P.L. Viana 1960, 13.IX.2002, fl. (BHCB, K); Santo Antônio do Itambé, Pico do Itambé, 1825'S, 4321'W, L. Rossi et al. CFCR 2993, 4.IV.1982, fl., fr. (SPF); subida ao Pico do Itambé, 18느'S, 4321'W, A. Furlan et al. CFCR 3045, 5.IV.1982, fl., fr. (SPF).

Coccocypselum pedunculare é endêmica de Minas Gerais (Costa 2004). Na Serra do Cipó, ocorre em solos arenosos entre rochas, com flores em fevereiro e julho. Diferencia-se das demais espécies principalmente pelas folhas sésseis, de margem revoluta e pelas inflorescências pedunculadas.

\section{Cordiera A.Rich. ex DC.}

Arbustos; ramos cilíndricos a apicalmente aplanados, em ramificação trifurcada, com a porção apical do entrenó estendida. Estípulas inteiras, triangulares ou múticas, muitas vezes prematuramente decíduas. Folhas opostas ou raramente verticiladas na base dos ramos, sésseis ou pecioladas. Flores unissexuadas (em plantas dioicas), actinomorfas, 5meras, em inflorescências terminais sésseis; hipanto hemigloboso, com tubo curto, truncado ou raramente curto-lobado; corola com prefloração contorcida, tubulosa, até duas vezes mais longa que o hipanto; ovário 2-5 locular. Bagas globosas, 2-5-loculares, pericarpo coriáceo, geralmente flexível; sementes numerosas, envolvidas por polpa amarelada. 
1. Folhas velutinas na face abaxial; bagas maduras verdes passando a amarelas 8.2. C. elliptica

1'. Folhas glabras na face abaxial; bagas maduras avermelhadas, vináceas ou negras

2. Estípulas vernicosas nos ramos vegetativos; corola externamente glabra; botões florais obtusos; bagas com mais de $10 \mathrm{~mm}$ diâm. 8.3. C. sessilis

2 '. Estípulas não vernicosas; corola externamente serícea; botões florais agudos; bagas até $6 \mathrm{~mm}$ diâm. 8.4. C. concolor

8.1. Cordiera concolor (Cham.) Kuntze, Revis. Gen. PI. 1: 279. 1891. Alibertia concolor (Cham.) K.Schum. in Mart., Eichler \& Urb., Fl. bras. 6(6): 388. 1889.

Nome vulgar: marmelada-de-pinto.

Fig. 1. C.

Arbusto 0,6-2(-3) $\mathrm{m}$ alt., ramos com casca avermelhada desprendendo-se em tiras, râmulos levemente pilosos, glabrescentes. Estípulas triangulares, $1 \mathrm{~mm}$ compr., não vernicosas, decíduas. Folhas opostas, raramente verticiladas na base dos ramos, sésseis ou pecioladas; pecíolo (0-)1-3 mm compr.; lâmina estreitamente a largamente elíptica ou oboval, base aguda a arredondada ou truncada, ápice agudo a truncado ou obtuso, (2-)2,5-5,5 cm compr., (1) 1,2-2,5 cm larg., cartácea, fortemente discolor, face abaxial fosca, secando castanho-clara ou olivácea com nervuras castanho-avermelhadas, face adaxial brilhante, secando castanho-escura a enegrecida, com nervuras mais claras, ambas as faces glabras; venação broquidódroma, nervuras secundárias 4-6 pares, salientes em ambas as faces, domácias barbeladas na junção com a nervura principal ocasionalmente presentes. Botões florais agudos, tubo da corola externamente seríceo; flores masculinas em grupos de 2-5, flores femininas solitárias; hipanto 2-2,5 $\mathrm{mm}$ compr., tubo do cálice truncado a levemente denteado; corola tubulosa, $5 \mathrm{~mm}$ compr., alva a rosada, lobos ereto-patentes, pilosos internamente (CFSC 13601). Bagas 3-6 mm diâmetro, pericarpo liso, verde passando a avermelhado, vináceos ou negros quando maduros; sementes 7-10, arredondadas, castanho-claras, ca. $3 \mathrm{~mm}$ compr.

Material examinado: Congonhas do Norte, Serra da Carapina (Serra Talhada na folha IBGE), setor $\mathrm{N}$ da Serra do Cipó, 1852'S, 4344'W, A. Rapini et al. 524, 2.III.1998, fr. (SPF); idem, 1852'12"S, 4344'14"W, J.R. Pirani et al. 4119, 2.III.1998, fr. (SPF); Serra Talhada (setor nordeste da Serra do Cipó), $9 \mathrm{~km} \mathrm{~S}$ de Congonhas do Norte na estrada para Conceição do Mato Dentro, entrada para Extrema seguindo $11 \mathrm{~km}$ - Fazenda Imbaúbas (propriedade do Sr. Helvécio Lacerda de Queiroz), 1855'78"S, 4340'42"W, L.M. Borges et al. 339, fl. (SPF); estrada para o vale do rio Preto, $9,6 \mathrm{~km}$ sudoeste da estrada Congonhas do Norte - Gouveia, entrada a $3,7 \mathrm{~km}$ noroeste de Congonhas do Norte, 1850'26"S, 43044'53"W, R. Mello-Silva et al. 2396, fl. (K, SPF). Jaboticatubas, Serra do Cipó, rodovia Lagoa Santa Conceição do Mato Dentro, km 132, M. Sazima \& J. Semir 3926, 16 a 24.II.1973, fr. (SP, UEC); nas proximidades da divisa do Parque, rumo a Conceição do Mato Dentro, H.F. Leitão Filho et al. 27357, 7.XII.1992, fl. (UEC). Santana de Pirapama, Serra do Cipó, T.B. Flores 280, 29.XI.2009, fr. (SPF); acesso por Inhame, Rio das Pedras, propriedade do
Sr. Luiz, 1901'27"S, 4517'26"W, D.C. Zappi et al. 2650, 29.XI.2009, fr. (K, SPF). Santana do Riacho, Serra do Cipó, Córrego Congonha, F.R. Salimena-Pires et al. CFSC 11411, 15.IV.1989, fr. (SPF); Rodovia Belo Horizonte - Conceição do Mato Dentro km 110, M.C. Assis \& J.R. Pirani CFSC 11462, 21.V.1989, fr. (SPF); km 118 (antigo 125), APA Morro da Pedreira, 1915'38"S, 43ํ3'10,3"W, J.R. Pirani et al. 5011, 5.III.2002, fr. (K, SPF); km 134, I. Cordeiro et al. CFSC 7518, 6.X.1981, fl. (F, MBM, SPF); km 138 antigo ao longo da rodovia Belo Horizonte - Conceição do Mato Dentro, M.G.L. Wanderley CFSC 5560, 14.VIII.1979, fr. (SP); Parque Nacional da Serra do Cipó, junto à sede do IBAMA do Alto do Palácio, J.R. Pirani CFSC 12277, 27.IV.1991, fr. (SPF); idem, J.R. Pirani \& R. Mello-Silva CFSC 11332, 24.III.1989, fr. (SPF); estrada MG-010, $400 \mathrm{~m}$ antes da bifurcação entre Morro do Pilar e Conceição do Mato Dentro, M.T.V.A Campos \& J.M. Arcanjo CFSC 13597, 18.III.1993, fl. (SP, SPF); Lapinha da Serra, trilha para o Pico do Breu, 190'59,4"S, 4340'35,7"W, L.M. Borges et al. 457, 16.VI.2010, fr. (SPF); RPPN Brumas do Espinhaço e Ermo do Gerais, C.A. Ferreira Junior et al. 593, 12.IX.2012, fr. (BHZB, SPF).

Cordiera concolor ocorre nos estados do Sudeste do Brasil, geralmente associada a vegetação campestre e alcança os campos rupestres da Bahia (Stannard \& Zappi 1995). O espécime Pirani 5011 não apresenta folhas discolores com nervação abaxial mais clara. O material Flores 280 apresenta características intermediárias entre $C$. concolor e $C$. elliptica.

8.2. Cordiera elliptica (Cham.) Kuntze, Revis. Gen. PI. 1: 279. 1891

Alibertia elliptica (Cham.) K. Schum. in Mart., Eichler \& Urb., Fl. bras. 6(6): 389. 1889.

Fig. 1. D.

Arbustos ou arvoretas 0,8-2 $\mathrm{m}$ alt., ramos com casca castanho-acinzentada desprendendo-se em tiras ou escamas quadrangulares, râmulos glabros. Estípulas triangulares a subuladas, $2-3 \mathrm{~mm}$ compr., não vernicosas, persistentes. Folhas opostas, pecioladas; pecíolo 2-5(-6) $\mathrm{mm}$ compr.; lâmina largamente elíptica ou oboval, base aguda a arredondada ou truncada, ápice agudo a truncado ou obtuso, 4-7 cm compr., 2,5-4 cm larg., cartácea, discolor, face abaxial velutina, secando castanho-clara ou olivácea, face adaxial secando castanha a verdeolivácea escura, com nervuras mais claras; venação broquidódroma, nervuras secundárias 5-6 pares, salientes em ambas as faces, retículo evidente, domácias dotadas de tricomas escamiformes na junção com a nervura principal. Botões florais agudos, com constrição apical, tubo da corola externamente 
Flora da Serra do Cipó, Minas Gerais: Rubiaceae

seríceo; flores masculinas em grupos de (5-)6-12, flores femininas solitárias; hipanto 2-4 mm compr., tubo do cálice truncado; corola tubulosa, 5-8 $\mathrm{mm}$ compr., alva a vinácea, lobos ereto-patentes, pilosos internamente. Bagas 10-12 mm diâm., pericarpo liso, verde passando a amarelo (raramente avermelhado) quando maduro; sementes 8-12, arredondadas, castanhas, ca. 3-3,5 $\mathrm{mm}$ compr.

Material examinado: Jaboticatubas, Parque Nacional da Serra do Cipó, trilha da base do IBAMA para Capão dos Palmitos, P. Fiaschi et al. 94, 26.IX.1999, fl. (SPF); proximidades do IBAMA, K. Yamamoto \& K. Matsumoto 30, 21.XI.2000, fr. (UEC); estrada para a sede do IBAMA, 19-20'S, 4337'W, L.S. Kinoshita \& A. Flores 359, 21.XI.2000, fl. (UEC); subida para a Serra das Bandeirinhas, por cima do córrego do Canyon dos Mascates, M.T.V.A Campos et al CFSC 12977, 8.IX.1992, fl. (SPF); Rodovia Lagoa Santa Conceição do Mato Dentro, km 114, J. Semir \& M. Sazima CFSC 3369, 5.IX.1972, fl. (SP, UEC); idem, km 117, J. Semir \& M. Sazima CFSC 3311, 3.IX.1972, fl. (SP); idem, km 126, J. Semir et al. CFSC 4340, 3.IX.1973, fl. (SP, UEC); idem, J. Semir et al. CFSC 4356, 3.IX.1973, fl. (SP, UEC). Itambé do Mato Dentro, entre o Canta Galo e a Serra da Cabeça de Boi, J.R. Stehmann \& M. Sobral 1115, 8.VIII.1992, fl. (UEC). Santana de Pirapama, Serra do Cipó, Fazenda Toucan Cipó, estrada para a captação, 1900'23"S, 4345'33"W, D.C. Zappi \& N.P. Taylor 2218, VIII.2009, fl. (K, RB, SPF). Santana do Riacho, F. Barros 362, 7.IX.1980, fl. (SP); Córrego Chapéu de Sol, R. Simão \& F.R. S. Pires CFSC 10443, 7.IX.1987, fl. (SPF); entre Faz. Palácio e Estátua do Juca, K. Yamamoto \& K. Matsumoto 50, 22.XI.2000, fr. (UEC); Cardeal Mota, estrada em frente à Pousada fazenda Monjolos, Trilha do Paredão, L.S. Kinoshita et al. C-012, 24.IX.2002, fl. (UEC); Rodovia Belo Horizonte - Conceição do Mato Dentro, km 104, Morro do Calcáreo, R.M. Harley et al. CFCR 5902, 13.XI.1984, fr. (K, SPF); km 106, I. Cordeiro \& J.R. Pirani CFSC 6496, 3.IX.1980, fl. (F, SP, SPF); km 109 (antigo 114) da estrada Lagoa Santa a Conceição do Mato Dentro, E. Forero et al. 7767 [CFSC 8689], 6.IX.1980; Estrada da Usina, I. Cordeiro et al. CFSC 6493, 24.VIII.1980, fl. (SP, SPF); idem, A.M. Giulietti et al. CFSC 5676, 16.IX.1979, fl. (SP); idem, M.C. Henrique et al. CFSC 7642, 31.X.1981, fr. (K, SPF); idem, M.C. Henrique et al. CFSC 7644, 31.X.1981, fr. (F, K, MBM, SPF); idem, G.L. Esteves et al. CFCR 6002, 15.XI.1984, fr. (K, SPF); idem, N.L.Menezes CFSC 6553, 7.IX.1980, fl. (SP); km 107, caminho para Usina Dr. Pacífico Mascarenhas, E. Forero et al. 7957 [CFSC 8870], 7.IX.1980, fl. (SP, SPF); idem, E. Forero et al. 8019 [CFSC 8932] 7.IX.1980, fl. (SP, SPF); idem, E. Forero et al. 8065 [CFSC 8978], 7.IX.1980, fl. (SP, SPF); idem, E. Forero 8070 et al. [CFSC 8983], 7.IX.1980, fl. (SP, SPF); estrada para Conceição do Mato Dentro, km 107-108, APA da Serra do Cipó, Morro da Pedreira, M. Alves et al. 2113, 23.VIII.2000, fl. (BHCB, SPF); estrada Lagoa Santa - Conceição do Mato Dentro (MG 010), altura do Córrego Duas Pontinhas, 1917'26,7"S, 4334'5,2"W, M.F. Calió et al. 144, fl. (K, SPF); idem, km 120-121, E. Forero et al. CFSC 8790, 6.IX.1980, fl. (SPF); estrada para Lapinha, $7 \mathrm{~km}$ após a cidade de Santana do Riacho, 1910'S, 4342'W, L.S. Kinoshita \& A.R. Barbosa 592, 23.XI.2000, fr. (UEC); Lapinha, Pico do Breu, A.M.G.A. Tozzi \& L.S. Kinoshita 557, 23.XI.2000, fr. (UEC); RPPN Brumas do Espinhaço e Ermo do Gerais, C.A. Ferreira Junior et al. 580, 11.IX.2012, fl. (BHZB, SPF); idem, J. Ordones et al. 2051, 26.XI.2012, fr. (BHZB, SPF).

Material adicional: Minas Gerais: Diamantina, estrada para Biri-biri, R.M. Harley et al. CFCR 6157, 18.XI.1984, fr.
(K, SPF); estrada para a gruta do Salitre e Distrito de Extração, H.F Leitão Filho et al. 27567 [UEC 69557]; $18 \mathrm{~km}$ leste de Diamantina, H.S. Irwin et al. 27850, 18.III.1970, fl. (K, NY, UB); Gouveia, Engenho Biblia, G. Hatschbach \& $R$. Kummrow 49619, 13.IX.1985, fl. (K, MBM); Monte Verde/Lima Duarte, Serra Negra, N.L. Abreu \& L. Menini Neto 233, 11.V.2008, fr. (CESJ, K); Sete Lagoas, Faz. da Tumba, D.M.S. Rocha 10379 [UEC 21093], 30.VIII.1979, fl. (UEC).

Cordiera elliptica ocorre nos cerrados e campos rupestres do Planalto Central do Brasil, nos estados de Minas Gerais, Bahia, Goiás e Distrito Federal. Na Serra do Cipó, ocorre em cerrado, e foi coletada com flores em agosto e frutificando em outubro e novembro. O material Kinoshita et al. C-012 apresenta características intermediárias entre $C$. elliptica e $C$. concolor.

8.3. Cordiera sessilis (Vell.) Kuntze, Revis. Gen. PI. 1: 279. 1891.

Alibertia sessilis (Vell.) K. Schum. in Mart., Eichler \& Urb., FI. bras. 6(6): 42. 1889.

Nomes vulgares: marmelada, marmelada-decachorro.

Fig. 1. E.

Arvoretas ou arbustos glabros, 2-4(-5) m alt., ramos com casca castanho-acinzentada ou levemente avermelhada. Estípulas triangulares a aristadas, 3-6 $\mathrm{mm}$ compr., vernicosas, decíduas a partir do terceiro nó. Folhas opostas, pecioladas; pecíolo (10-)15-20 mm compr.; lâmina amplamente elíptica a oval, base truncada a arredondada, ápice agudo ou acuminado, (9-)11-19 cm compr., (3-)4-8(-9) cm larg., firmemente cartácea, levemente discolor, face abaxial secando castanho-acinzentada a verde-olivácea, face adaxial ligeiramente mais escura, glabra; venação broquidódroma, nervuras secundárias 5-6 pares, salientes e com retículo saliente em ambas as faces, domácias em cavidades na junção com a nervura principal. Botões florais obtusos, tubo da corola externamente vernicoso, glabro; flores masculinas em grupos de (4-)5-10, flores femininas solitárias; hipanto 1,5 mm compr., tubo do cálice truncado, com margem cartilaginosa; corola tubulosa, 7-8 mm compr., alva, lobos patentes. Bagas 15-25 mm diâmetro, pericarpo liso, verde passando a vináceo ou atropurpúreo quando maduro; sementes 8-10, arredondadas, amarelo-claras, ca. $5 \mathrm{~mm}$.

Material examinado: Itambé do Mato Dentro, distrito de Santana do Rio Preto (Cabeça de Boi), APA do Parque Nacional da Serra do Cipó, 19²5'54,7"S, 4325'58,3"W, M.F. Santos \& L.M. Borges 217, 18.XII.2007, fl. (BHCB, SPF). Santana de Pirapama, Serra do Cipó, acesso pela Fazenda Inhame, estrada entre Capela de São José e Santana do Riacho, Faz. Toucan Cipó, D.C. Zappi et al. 1818, 7.III.2009, fr. (K, RB, SPF); Rio das Pedras, propriedade do Sr. Luiz, 1901'27"S, 4345'17"W, D.C. Zappi et al. 2656, 29.XI.2009, fr. (K, SPF). [Santana do Riacho] Cardeal Mota, estrada em frente à Pousada Fazenda Monjolo, L.S. Kinoshita et al. C010, 24.IX.2002, fl. (UEC). 
Material adicional: Goiás: Colinas do Sul, $5 \mathrm{~km}$ do Rio Tocantins, $13^{\circ} 51$ 'S, $48^{\circ} 18^{\prime} \mathrm{W}$, B.M.T. Walter et al. 815, 21.XI.1991, fr. (CEN, K). Minas Gerais: Lagoa Santa, Warming s.n., 5.VIII.1863, fl. (C, K); Uberlândia, Faz. Buriti, G.M. Araújo et al. 1021, 2.X.1993, fr. (HUFU, K).

De ocorrência ampla nos cerrados do Brasil (São Paulo, Minas Gerais, Mato Grosso, Mato Grosso do Sul, Goiás, Distrito Federal, Maranhão e Tocantins), Cordiera sessilis ocorre também no Paraguai e na Bolívia (Govaerts 2013). Foi coletada em cerrado e cerradão na região noroeste da Serra do Cipó, com frutos em março, e observada com flores durante o mês de julho.

\section{Coussarea Aubl.}

Arbustos a árvores; ramos cilíndricos a aplanados, apresentando ramificação trifurcada. Estípulas inteiras, triangulares, persistentes. Folhas opostas ou 3-verticiladas, pecioladas ou não; domácias geralmente presentes. Inflorescências cimosas, terminais, pedunculadas, ocasionalmente sésseis. Flores bissexuadas, actinomorfas, 4-5-meras; hipanto turbinado, com tubo desenvolvido, truncado, laciniado ou denteado; corola com prefloração valvar; tubulosa, duas ou mais vezes mais longa que o cálice; ovário 2-locular. Drupas ovoides a elipsoides, unisseminados.

9.1. Coussarea congestiflora Müll.Arg., Flora 58: 466. 1875.

Fig. 6. A-B.

Arvoreta glabra, $3 \mathrm{~m}$ alt.; ramos aplanados, casca castanho-amarelada com lenticelas mais claras, alongadas. Estípulas triangulares, 4-5 x 6-7 mm. Folhas opostas, pecioladas; pecíolo 12-15 mm compr.; lâmina elíptica a largamente oboval, base aguda a atenuada, ápice agudo a acuminado, 11-25 cm compr., 4-9(-9,5) cm larg., cartácea, ligeiramente discolores, secando verde a verde-oliváceas, com nervuras mais claras em ambas as faces; venação broquidódroma, nervuras salientes em ambas as faces, domácias situadas sobre ou na axila das nervuras secundárias. Inflorescências piramidais, pedúnculo 4-6 cm; botões florais pedicelados, agudos, com leve constrição subapical e tubo da corola externamente seríceo, acinzentado; hipanto 2-3 mm compr., tubo do cálice amplo, truncado, levemente denteado; corola 10-13 mm compr., alva, tubulosa, lobos ereto-patentes. Drupas elipsoides até $6 \mathrm{~mm}$ diâm., pericarpo liso, verde passando a amarelo quando maduro; pirênio ósseo, amarelado, costelado, ca. $5 \mathrm{~mm}$ compr.

Material examinado: Itambé do Mato dentro, distrito de Santana do Rio Preto (Cabeça de Boi), APA do Parque Nacional da Serra do Cipó, 1923'46,9"S, 4324'7,4"W, M.F. Santos \& H. Serafim 334, 16.III.2008 (SPF). Santana de Pirapama, Serra do Cipó, Fazenda Toucan Cipó, estrada para a captação, D.C. Zappi et al. 732, 15.II.2007, fr. (ESA, HUEFS, K, SPF); idem, 1900'23"S, 4345'33"W, D.C. Zappi et al. 2712, 4.III.2010, fr. (K, RB, SPF); Capela de São José, trilha da Senhorinha, caminho a Congonhas do Norte, 185'3,2"S, 4344'59"W, D.C. Zappi et al. 2515, 24.XI.2009, fr. (SPF). Santana do Riacho, Serra do Cipó, estrada Belo Horizonte - Conceição do Mato Dentro, km 123, Córrego Três Pontinhas, J.R. Pirani \& I. Cordeiro CFSC 7677, 3.XI.1981, fl. (SPF).

Espécie endêmica do Brasil (estados de Minas Gerais e Rio de Janeiro), ocorre na Serra do Cipó em mata seca semidecidual e matas ciliares, tendo sido coletada com flores em novembro e em fruto em fevereiro e março.

\section{Coutarea Aubl.}

Arbustos escandentes ou semi-apoiantes ou árvores de médio porte; ramos aplanados, fortemente lenticelados, apresentando ramificação paralela ao solo. Estípulas inteiras, deltoides a triangulares, livres, persistentes. Folhas opostas, perenes ou decíduas, pecioladas, domácias geralmente presentes, formadas por tufos de tricomas nas axilas das nervuras secundárias. Inflorescências terminais, cimosas dicasiais, pedunculadas ou ocasionalmente subsésseis. Flores bissexuadas, actinomorfas a zigomorfas, 6-meras; hipanto turbinado, com tubo curto, laciniado; corola com prefloração imbricada, zigomorfa, campanulada, vistosa; estames e estigma exsertos; ovário 2-locular, lóculos pluriovulados. Cápsulas loculicidas comprimidas, deiscentes a partir da base, rígidas e lenticeladas; sementes aladas, inúmeras.

10.1. Coutarea hexandra (Jacq.) K.Schum. in Mart., Eichler \& Urb. , FI. bras. 6(6): 196. 1889.

Nome vulgar: quina-quina.

Fig. 2. G.

Arbusto semi-escandente, 1-2 m alt. ou árvores até $10 \mathrm{~m}$ alt.; ramos aplanados, com casca acinzentada e lenticelas salientes, arredondadas. Estípulas triangulares, 3-4 mm compr., 2-3 mm larg. Folhas decíduas, pecioladas; pecíolo 5-8 mm compr., pilósulo; lâmina elíptica a oval ou arredondada, base arredondada a decorrente, margem plana, ápice agudo a acuminado, 3-6 cm compr., 1,5-3,5 cm larg., cartácea, ligeiramente discolor, secando verde-clara na face abaxial, verde a verde-olivácea com nervuras mais claras na face adaxial, pilósula na face abaxial; venação broquidódroma, nervuras secundárias 4-6(-7) pares, nervuras salientes na face abaxial, impressas na face adaxial, com domácias hirsutas nas axilas. Inflorescências em dicásios reduzidos, trifurcados, pedúnculos até $1 \mathrm{~cm}$ compr.; botões florais obovados, obtusos; hipanto 8-14 mm compr., tubo do cálice curto, lobos estreitamente triangulares a subulados; corola 4-5,5 cm compr., zigomorfa, campanulada, glabro, variando de alvo a rosada, com ou sem estrias 


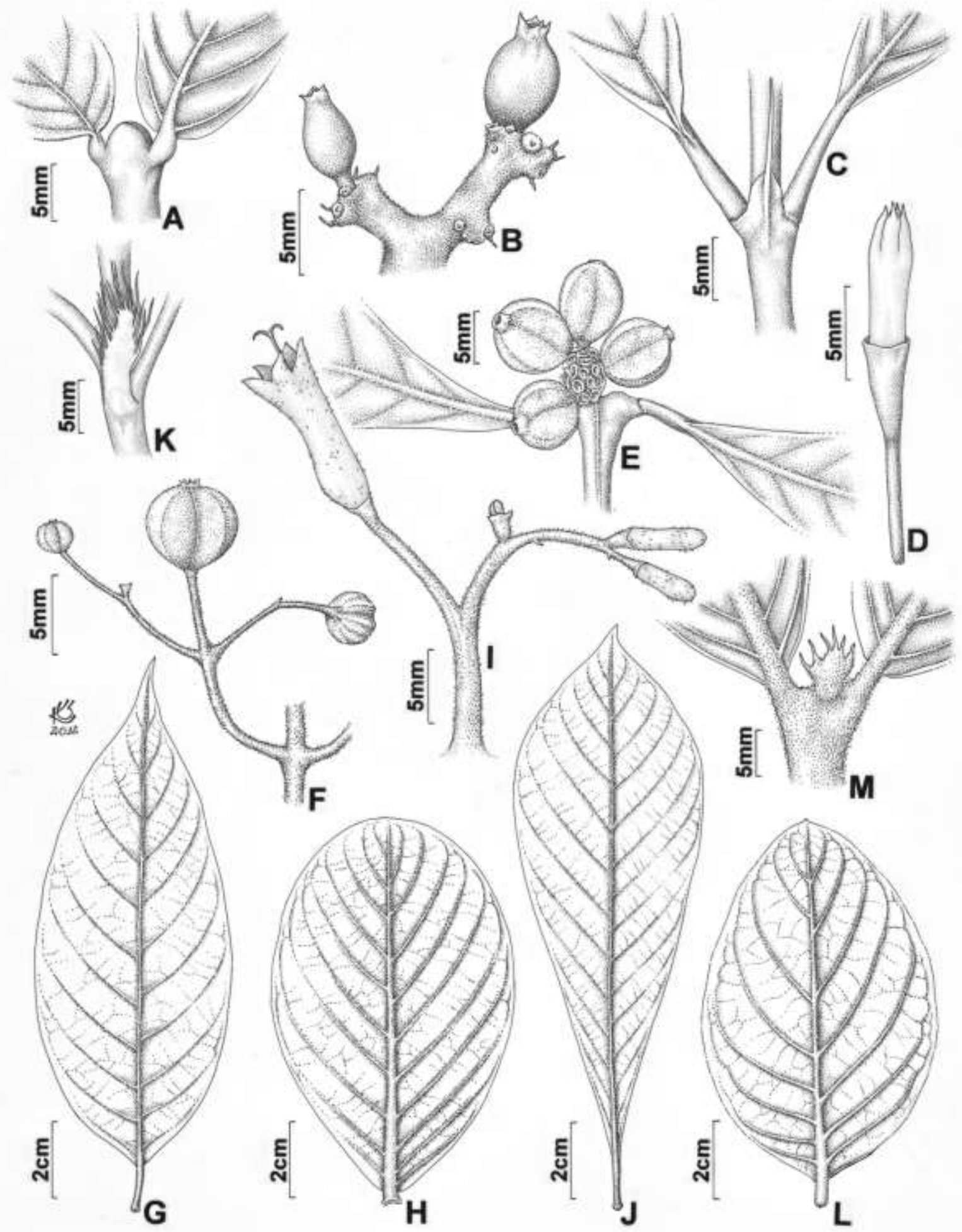

Fig. 6 - Arbustos a árvores, frutos drupáceos 1-2-seminados, tribo Farameae e Psychotrieae (excl. Psychotria). A-B. Coussarea congestiflora. A. Estípula. B. Detalhe da infrutescência. C-D. Faramea nigrescens. C. Estípula. D. Botão floral. E. Margaritopsis cephalantha, Infrutescência. F-G. Palicourea marcgravii. F. Detalhe da infrutescência. G. Folha. H. Palicourea rigida, Folha. I-J. Palicourea tetraphylla. I. Detalhe da inflorescência. J. Folha. K. Rudgea sessilis subsp. cipoana, Estípula. L-M. Rudgea viburnoides. L. Folha. M. Estípula. (A-B: Zappi 2712. C-D: Oliveira 18. E: Araújo 992. F-G: Zappi 1833. H: Harley 19544. I-J: Zappi 2505. K: CFSC 4657. L-M: Krieger \& Câmara 8793). 
vináceas a rosadas, lobos 6 , recurvados; estames exsertos, lineares; estilete exserto, estigma capitado. Cápsulas bilobadas, aplanadas, 1,2-3 cm larg., castanhas com lenticelas creme, coroadas pelos restos do cálice quando maduras; sementes aladas, até $6 \mathrm{~mm}$ larg.

Material examinado: Santana de Pirapama, Serra do Cipó, Capela de São José, Fazenda Toucan Cipó, mata perto dos estábulos, 1900'18"S, 4346'34"W, D.C. Zappi et al. 2756, 7.III.2010, fr. (K, SPF). Santana do Riacho, Cardeal Mota, Serra do Cipó, APA Morro da Pedreira, trilha para o Morro da Pedreira, a partir da estrada para Lapinha e Santana do Riacho, 1918'21,7"S, 4336'58,6"W, M.F. Calió et al. 171, 17.I.2007, fl. (SPF).

Espécie amplamente distribuída na América do Sul (Govaerts 2013), ocorre em todo o Brasil, frequentemente associada a florestas deciduais ou semideciduais, onde pode ser um arbusto muito comum. O material observado na Serra do Cipó apresenta corola alva, mas em outras localidades a corola pode apresentar-se rosa-forte, mais expandida e muito chamativa. Na Serra do Cipó, foi coletada apenas nos setores sudoeste e noroeste da serra, em mata seca semidecidual e decidual, observada com lores em novembro e coletada com frutos em março.

\section{Declieuxia Kunth}

Ervas perenes, subarbustos ou arbustos; ramos cilíndricos, 2-costelados ou não. Estípulas interpeciolares, 1-3-lobadas, terminando numa glândula, raramente inconspícuas, base decorrente ou não. Folhas opostas ou 3-7-verticiladas, sésseis ou pecioladas, indumentadas ou glabras, algumas com pares de folhas menores nas axilas. Inflorescências cimosas ou raramente flores solitárias, terminais e/ou axilares. Flores bissexuadas, actinomorfas, 4-meras, heterostílicas, curto-pediceladas ou sésseis; lacínios persistentes no fruto; corola com prefloração valvar, hipocrateriforme, alva a azul, internamente papilosa no 1/4 distal, glabra no 1/4 proximal e serícea entre as extremidades, prefloração valvar; estames 4 , exsertos ou inclusos, inseridos próximo ao ápice ou na metade superior do tubo (respectivamente); anteras introrsas; ovário bilocular, lóculos uniovulados, raramente biovulados, estigma bífido. Fruto esquizocárpico, formado por 2 mericarpos, complanados ou subglobosos, elípticos a circulares; sementes 2, lenticulares.

Chave para as espécies

1. Folhas sésseis; lâmina com base cordada, truncada ou cuneada.

2. Lâmina foliar com base cordada ou truncada, nervuras secundárias da base da folha fortemente arqueadas.

3. Estípulas inconspícuas; flores solitárias ou inflorescências com 3 flores; hipanto estrigoso; frutos estrigosos a esparsamente estrigosos

3'. Estípulas conspícuas; inflorescências com 50-300 flores; hipanto glabro; frutos glabros.

4. Erva perene; caule estrigoso a densamente estrigoso; folhas verdes, estrigosas a esparsamente estrigosas (raramente glabras), 4-18 mm larg. ..... 11.1. D. cordigera

4'. Subarbusto; caule glabro; folhas glaucas, glabras, 18-46 mm larg. 11.2. D. deltoidea

2'. Lâmina foliar com base cuneada, nervuras secundárias inconspícuas ou se conspícuas, basais não fortemente arqueadas.

5. Entrenós não-costelados, estípula com base não decorrente; folhas 0,6-1,8 mm larg., uninérveas.

6. Planta $12-40 \mathrm{~cm}$ alt.; folhas estrigosas, opostas ou verticiladas, não encobrindo os entrenós

6'. Planta $4-10 \mathrm{~cm}$ alt.; folhas glabras, verticiladas, cobrindo os entrenós 11.5. D. gracilis

5'. Entrenós 2-costelados, estípula com base decorrente; folhas 2,5-20 mm larg., venação eucamptódroma ou broquidódroma.

7. Arbusto ou subarbusto; entrenós $10-50 \mathrm{~mm}$ compr.; folhas $14-33 \mathrm{~mm}$ compr., 4,5-20 mm larg.

7'. Erva perene; entrenós 3-16 mm compr.; folhas 14,5-55 mm compr., 2,5-11 mm larg.

1'. Folhas pecioladas, o pecíolo alado; lâmina com base atenuada a longamente atenuada.

8. Erva perene, até $13 \mathrm{~cm}$ alt.

9. Caule estrigoso; 2 ou mais flores na inflorescência

9'. Caule glabro; flores solitárias

8'. Sebarbusto ou arbusto, $15 \mathrm{~cm}$ alt. ou mais.

10. Axilas foliares sem fascículos de pequenas folhas

10 '. Axilas foliares com fascículos de pequenas folhas.

11. Folhas 9-15 mm larg.; inflorescência com 80-180(-330) flores

11 '. Folhas 0,7-4 mm larg.; inflorescência com 7-24(60) flores.

12. Plantas estrigosas; estípulas com base não decorrente; folhas $5,5-13 \mathrm{~mm}$ compr.

12'. Plantas glabras; estípulas com base decorrente; folhas $14-30 \mathrm{~mm}$ compr.

11.10. D. passerina 
11.1. Declieuxia cordigera Mart. \& Zucc. ex Schult. \& Schult.f., Mant. 3: 112. 1827.

Fig. 7. A.

Erva perene, $15-33 \mathrm{~cm}$ alt.; caule estrigoso a densamente estrigoso, entrenós 6-23 mm compr. Estípulas conspícuas, 1-dentadas, base não decorrente, 0,2-0,6 x 0,1-0,5 mm. Folhas opostas, raramente verticiladas, sésseis, sem pares de folhas menores nas axilas; lâmina oval a largamente oval, base cordada, raramente truncada, margem plana a fracamente revoluta, ápice acuminado a cuspidado, 6$19 \mathrm{~mm}$ compr., 4-18 mm larg., 0,9-1,8 vez mais longa que larga, subcoriácea, geralmente discolor, com face adaxial mais escura do que a abaxial, estrigosa a esparsamente estrigosa, raramente glabra; venação broquidódroma, com nervuras basais fortemente arqueadas, nervuras salientes em ambas as faces. Inflorescências terminais, 50-90(650) flores sésseis, hipanto glabro; lacínios estreitamente oblongos ou largamente deltoides a triangulares, ápice obtuso ou agudo, 0,4-0,5 mm compr., 0,2-0,4 mm larg.; corola azul, tubo 3,5-6,5 mm compr., 0,5-0,9 mm larg. na base, lobos triangulares, ápice agudo, 1,6-2,5 mm compr., $0,6-1,4 \mathrm{~mm}$ larg.; filetes $0,2-0,9$ ou ca. $2 \mathrm{~mm}$ compr., anteras 0,8-1 mm compr.; estilete 4 ou 4,5-5,6 $\mathrm{mm}$ compr., estigma 0,6-1,4 mm compr. Mericarpos glabros, 1,2-1,8 mm compr., 0,9-1,6 mm larg.

Material examinado: Congonhas do Norte, estrada para Gouveia, ca. $9 \mathrm{~km}$ de Congonhas do Norte, 1846'25,3"S, 4344'18,7"W, M.F. Calió et al. 199, 21.I.2007, fl., fr. (SPF). Jaboticatubas, rodovia Lagoa Santa - Conceição do Mato Dentro - Diamantina, km 126, A.B. Joly et al. CFSC 1051, 5.III.1972, fl., fr. (SP); idem, A.B. Joly et al. CFSC 1085 , 5.III.1972, fl., fr. (SP). Santana de Pirapama, Serra do Cipó, Capelas de São José, Trilha da Senhorinha, caminho a Congonhas do Norte, $18^{\circ} 56^{\prime} 10,1^{\prime \prime S}, 43^{\circ} 45^{\prime} 74 " W$, D.C. Zappi et al. 2489, 26.XI.2009, fl. (K, SPF); Fazenda Inhame (Serra Mineira), $18^{\circ} 55^{\prime} \mathrm{S}, 4^{\circ} 54^{\prime} \mathrm{W}$, J.R. Pirani et al. CFSC 8085 , 22.III.1982, fl., fr. (SPF); 7 km ENE de São José de Almeida, hacia Conceição do Mato Dentro, $19^{\circ} 26^{\prime}$ S, $43^{\circ} 48^{\prime} \mathrm{W}$, M.M. Arbo et al. 4784, 10.ll.1991, fl., fr. (SPF); 22 km NE de São José de Almeida, caminho para Santana do Riacho, 19¹8'S, 4346'W, M.M. Arbo et al. 4913, 11.II.1991, fl., fr. (SPF). Santana do Riacho, $20 \mathrm{~km}$ do início da estrada para Santana do Riacho, saindo da estrada Lagoa Santa - Conceição do Mato Dentro (MG 010), 19¹5'29,1"S, 4342'59,2"W, M.F. Calió et al. 136, 23.VII.2006, fl., fr. (MBM, SPF).

Kirkbride (1976) reconheceu três variedades nessa espécie, distintas principalmente pela forma, ápice e base da lâmina foliar. Na Serra do Cipó, ocorre apenas Declieuxia cordigera var. cordigera, encontrada do leste de São Paulo e sul da Bahia até Goiás (Kirkbride 1976), em cerrado com solo vermelho e em campo rupestre com solo arenoso. É facilmente diagnosticada devido ao hábito herbáceo e às folhas cordiformes. Difere de $D$. passerina principalmente devido à razão menor entre comprimento e largura das folhas e pelas inflorescências terminais com muitas flores. Distingue-se dos espécimes de $D$. fruticosa pela venação actinódroma e estípulas com base não decorrente. Coletada em flor e fruto nos meses de fevereiro, março e novembro.

11.2. Declieuxia deltoidea Müll.Arg., Flora 59 (28): 437. 1876.

Fig. 7. B-E.

Subarbusto (15)35-150 cm alt.; caule fistuloso, glabro, entrenós 10-41 $\mathrm{mm}$ compr. Estípulas conspícuas, 1-3-dentadas, raramente largamente deltoides, base não decorrente, 0,2-1,1 x 0,1-0,3 mm. Folhas opostas, sésseis, raramente com folhas menores nas axilas; lâmina depresso-oval a largamente depresso-oval, base cordada (raramente arredondada), margem plana, espessada, ápice acuminado a abruptamente acuminado ou obtuso,12$35 \mathrm{~mm}$ compr., 18-46 mm larg., 0,3-0,9 vez mais longa que larga, subcoriácea, glauca, face abaxial geralmente mais clara do que a face adaxial, glabra; venação broquidódroma, com nervuras basais fortemente arqueadas, nervuras salientes em ambas as faces. Inflorescências terminais, 100-300 flores pediceladas, pedicelo 0,3-0,6 $\mathrm{mm}$ compr.; hipanto glabro; lacínios estreitamente triangulares a largamente deltoides, raramente curto-triangulares ou oblongas, ápice agudo a arredondado, 0,3-0,6 mm compr., 0,1-0,5 mm larg.; corola azul, tubo 4,4-8,2 mm compr., 0,9-1,3 mm larg. na base, lobos triangulares, ápice agudo, 1,9-2,7 mm compr., 0,4-1,6 mm larg.; filetes $0,1-0,4$ ou 0,8-1,4 mm compr., anteras 1- 1,8 $\mathrm{mm}$ compr; estilete 4-8 ou 3,5-4 mm compr., estigma 0,3-1 mm compr. Mericarpos glabros, 2-3,3 mm compr., 1,6-2,5 mm larg.

Material examinado: Congonhas do Norte, Serra Mangatuba, margem direita do Rio Preto, $18^{\circ} 50^{\prime} \mathrm{S}, 43^{\circ} 49^{\prime} \mathrm{W}$, A. Furlan et al. CFSC 8462, 23.IV.1982, fl., fr. (SPF); Jaboticatubas, A.B. Joly et al. CFSC 2318, 28.V.1972, fl., fr. (SP); Morro do Cruzeiro, flanco $\mathrm{N}$ do Vale do Rio Cipó, M.T.V.A. Campos CFSC 13123, 2.V.1993, fl., fr. (SPF), Jaboticatubas, Estrada da Usina -c. $10 \mathrm{~km}$ da entrada da estrada principal, A.B. Joly \& J. Semir CFSC 3031, 21.VIII.1972, fl. (SP). Santana de Pirapama, Serra do Cipó, acesso pela Faz. Inhame, início da trilha da Senhorinha, 1857'39"S, 4346'10"W, D.C. Zappi et al. 1652, 27.II.2007, fl., fr. (K, SPF); Fazenda Inhame (Serra Mineira), $18^{\circ} 55^{\prime} \mathrm{S}$, 4354'W, J.R. Pirani et al. CFSC 8049, 22.III.1982, fl., fr. (SPF); Serra do Cipó, Fazenda Toucan Cipó, estrada para captação, $19^{\circ} 00^{\prime} 18^{\prime \prime S}, 43^{\circ} 46^{\prime} 6 " W$, D.C. Zappi et al. 702, 15.II.2007, fl., fr. (ESA, K, SPF); idem, 1900'20,9"S, 4346'1,2"W, G.P. Lewis et al. 3839, 26.XI.2009 (SPF); idem, $19^{\circ} 00^{\prime 2} 25^{\prime S}, 43^{\circ} 45^{\prime} 35 " W$, D.C. Zappi et al. 2788, 10.III.2010, fl., fr. (K, SPF). Santana do Riacho, Parque Nacional da Serra do Cipó, caminho para Vale do Rio Cipó, E.A. Anunciação 236, 2.V.1993, fl., fr. (SP); Cardeal Mota, estrada para o Mirante do Cruzeiro, M.F. Calió et al. 10, 8.VI.2002, fl., fr. (SPF); 35 km do início da estrada para Santana do Riacho, 


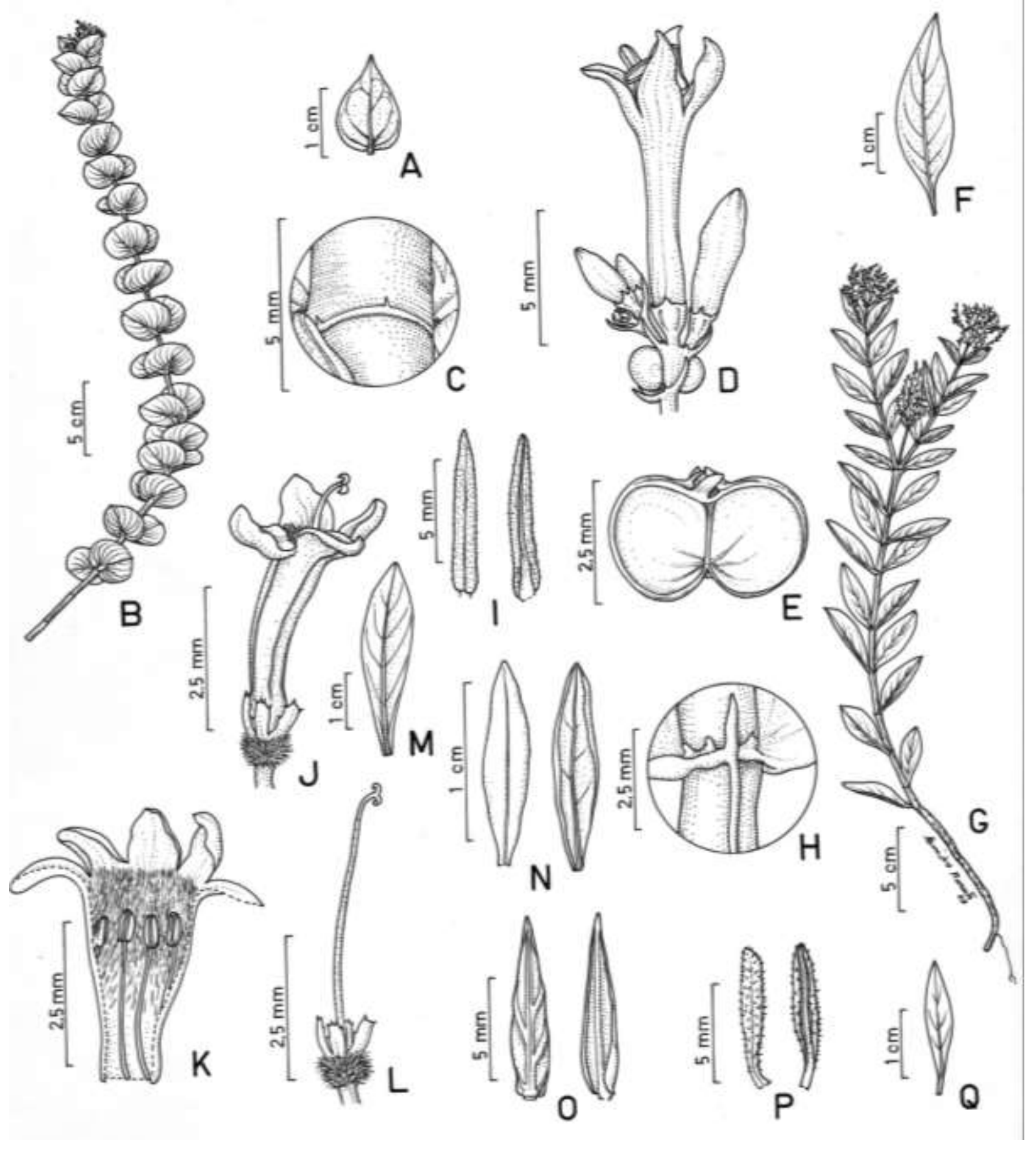

Fig. 7 - Herbáceas ou subarbustivas, frutos que se dividem em mericarpos (Declieuxia). A. Declieuxia cordigera var. cordigera, Folha. B-E. D. deltoidea var. deltoidea: B. Hábito. C. Estípula com base não decorrente. D. Ápice de inflorescência com flor brevistila. E. Fruto. F. D. diantheroides, Folha. G-H. D. fruticosa. G. Hábito; H. Estípula com base decorrente. I-L. D. gracilis. I. Folha. J. Flor longistila. K. Corola rebatida. L. Gineceu. M. D. leiophylla, Folha. N. D. irwinii, Folha. O. D. passerina, Folha. P. D. saturejoides, Folha. Q. D. spergulifolia, Folha. (A: Joly et al. CFSC 1051. B-C: Calió et al. 10. D-E: Campos et al. CFSC 13123. F: Lima et al. 152. G-H: Calió et al. 7. I: Joly et al. CFSC 1777. J-L: Semir \& Joly CFSC 3715. M: CFSC 8110. N: Semir \& Sazima CFSC 3368. O: Pirani et al. CFSC 8085. P: Mello Barreto 8781. Q: Pirani et al. 4114). 
saindo da estrada Lagoa Santa - Conceição do Mato Dentro (MG 010), 1907'09,7"S, 4341'53,0"W, M.F. Calió et al. 141, 23.VII.2006, fl., fr. (SPF); about $8 \mathrm{~km}$ beyond the church in Santana do Riacho on the road to Lapinha and Pico do Breu, -19.11490으, -43.69937ㅇ, F. Almeda et al. 9724, 5.III.2009, fl., fr. (UEC); estrada Santana do Riacho - Lapinha, 190' 4341'W, R.C. Forzza et al. 760, 5.III.1998, fl., fr. (SPF); 7-12 $\mathrm{km} \mathrm{N}$ de Santana do Riacho, camino a Lapinha, ca. 1910'S 4341'W, M.M. Arbo et al. 4844, 11.II.1991, fl., fr. (SPF); Lapinha, $19^{\circ} 06^{\prime} 05^{\prime \prime S}, 43^{\circ} 40^{\prime} 36^{\prime \prime W}$, J.R. Pirani et al. 5520 22.IV.2006, fl., fr. (SPF); Lapinha, Pico do Breu, 1906'44"S, 4341'53"W, L.S. Kinoshita \& L. Yamamoto 02/228, 24 27.IX.2002, fl., fr. (UEC); idem, K. Yamamoto et al. C-180 27.IX.2002, fl., fr. (UEC); $7 \mathrm{~km}$ da praça central da cidade, $P$. Fiaschi \& F.N. Costa 344, 21.VI, 2000, fl., fr. (SPF); Serra da Bandeira, G.P. Lewis et al. CFSC 7794, 17.II.1982, fl., fr. (SPF); Serra do Cipó, acesso pela Faz. Inhame, Trilha do João Carrinho, 1903'02"S, 4344'29"W, D.C. Zappi et al. 1584, 25.II.2007, fl., fr. (K, SPF); idem, 1902'55"S, 4343'48"W, D.C. Zappi \& N.P. Taylor 2239, 25.VII.2009, fl., fr. (K, SPF); idem, $19,0480^{\circ} \mathrm{S}, 43,7387^{\circ} \mathrm{W}$, V.C. Souza et al 32655, 18.Il.2007, fl., fr. (ESA, K); RPPN Brumas do Espinhaço e Ermo do Gerais, M.G.C. Fernandes et al. 1733, 27.XI.2012, fl., fr. (BHZB, SPF).

Kirkbride (1976) reconhece duas variedades nessa espécie, distintas principalmente pelo número de lobos das estípulas. Na Serra do Cipó, é encontrada apenas Declieuxia deltoidea var. deltoidea, que ocorre na Cadeia do Espinhaço de Minas Gerais, de Diamantina à Serra do Cipó, e a oeste da Serra do Cabral (Kirkbride 1976), em cerrado com solo pedregoso ou campo rupestre, sempre crescendo entre as rochas. É facilmente identificada por suas folhas glaucas, depresso-ovais a largamente depresso-ovais, com base cordada. Na Serra do Cipó, é extremamente comum nas encostas da face noroeste das serras (Santana de Pirapama/Santana do Riacho). Distingue-se de $D$. fruticosa por suas estípulas não decorrentes, razão menor entre comprimento e largura das folhas e tricomas nas axilas das folhas. Coletada em flor e fruto de fevereiro a junho.

11.3. Declieuxia diantheroides Standl., Publ. Field Mus., Bot. 22 (3): 185.1940.

Fig. 7. F.

Arbusto ou subarbusto $50-100 \mathrm{~cm}$ alt:; caule estrigoso, entrenós 15-40 $\mathrm{mm}$ compr. Estípulas conspícuas, 1-dentadas, base decorrente, 2,2-3 x 0,2 $\mathrm{mm}$. Folhas opostas, pecioladas; pecíolo alado, 2-3 $\mathrm{mm}$ compr., com 2-3 pares de folhas menores nas axilas; lâmina elíptica a estreitamente elíptica, base longamente atenuada, margem levemente revoluta, ápice longamente acuminado, 23-50 mm compr., 9-15 mm larg., 2,3-5 vezes mais longa que larga, cartácea, estrigosa; venação broquidódroma, nervuras levemente salientes na face abaxial e levemente impressas na face adaxial. Inflorescências terminais,
80-180(-330) flores pediceladas; pedicelo 0,2-0,3 mm compr.; hipanto glabro a estrigoso; lacínios triangulares, ápice arredondado, ca. 0,3 mm compr., ca 0,2 mm larg.; corola alva, tubo 2-3 mm compr., 0,4$0,7 \mathrm{~mm}$ larg. na base, lobos triangulares a estreitamente triangulares, ápice agudo, 1,4-1,9 mm compr., 0,5-0,9 mm larg.; filetes $0,2-0,3$ ou ca. $1,1 \mathrm{~mm}$ compr., anteras 0,7-1 mm compr.; estilete 3,3-4 ou ca. $3 \mathrm{~mm}$ compr., estigma 0,4-0,6 mm compr. Mericarpos estrigosos, 1,5-1,7 mm compr., 1-1,4 mm larg.

Material examinado: Jaboticatubas, Serra do Cipó, estrada para a sede do IBAMA, F.A. Vitta 290, 24.V.1996, fl., fr. (UEC). Santana de Pirapama, Capela de São José, Estrada da Captação da Fazenda Toucan Cipó, 1900'12"S, 4345'21"W, D.C. Zappi et al. 2778, 10.III.2010, fl., fr. (K, SPF); idem, 1900'18,5"S, 4345'6,2"W, D.C. Zappi et al. 2435, 18.XI.2009, fl., fr. (K, SPF). Santana do Riacho, Serra do Cipó, rodovia MG 010, km 107, P.T Sano et al. 566, 21.X.1997, fl., fr. (SPF); idem, km 114, F. Vale 14, 6.VII.1994, fl., fr. (SPF); idem, km 2, Estrada da Usina, A.B. Joly et al. CFSC 1221, 5.III.1972, fl., fr. (SP); idem, lado direito da estrada partindo de Belo Horizonte, logo após a fazenda Palácio, 1916'59"S, 4334'51"W, J.A. Lombardi \& L.G. Temponi 2469, 2.II.1999, fl., fr. (BHCB); APA Morro da Pedreira, estrada para a entrada do Parque Nacional, ca. 2 $\mathrm{km}$ da Rodovia MG 010, 1920'53"S, 4338'51"W, L.R. Lima et al. 152, 7.III.2002, fl., fr. (K, SPF); acesso por Inhame, Trilha do João Carrinho, 1903'5,4"S, 4344'29,6"W, D.C. Zappi et al. 2631, 28.XI.2009, fl. (K, SPF); idem, 1902'42" S, $43^{\circ} 44^{\prime} 06^{\prime \prime}$ W, D.C. Zappi et al. 2808, 11.III.2010, fl. (K, SPF).

Segundo Kirkbride (1976), essa espécie é conhecida apenas de Conselheiro da Mata (Planalto de Diamantina) e Serra do Cipó. Distingue-se facilmente das outras por suas inflorescências e pedúnculos evidentemente mais longos. Além disso, apresenta, juntamente com $D$. spergulifolia, as folhas de textura mais fina, diferenciando-se dessa também pela forma da lâmina e menor razão entre comprimento e largura das folhas. É encontrada geralmente em cerrados associados a campos rupestres, com flores e frutos nos meses de fevereiro e março.

11.4. Declieuxia fruticosa (Willd. ex Roem. \& Schult.) Kuntze, Revis. gen. pl. 1: 279. 1891.

Fig. 7. G-H.

Arbusto ou subarbusto $15-70 \mathrm{~cm}$ alt., caule glabro a densamente estrigoso, entrenós 10-50 mm compr. Estípulas conspícuas, 1-dentadas, base decorrente, $0.7-4,5 \times 0,2-0,4 \mathrm{~mm}$. Folhas opostas, sésseis ou pecioladas; pecíolo alado, 0-2 mm compr., sem pares de folhas menores nas axilas; lâmina estreitamente elíptica a largamente elíptica ou oval a largamente oval, base cuneada a atenuada, margem plana, ápice agudo, 14-33 mm compr., 4,5-20 mm larg., 1,3-5 vezes mais longa que larga, cartácea a 
subcoriácea, geralmente discolor, com face abaxial mais clara do que a adaxial, glabra a estrigosa; venação eucamptódroma ou broquidódroma, nervuras salientes na face abaxial. Inflorescências terminais, (40)60-330 flores pediceladas; pedicelo 0,1-0,5 mm compr.; hipanto glabro a densamente estrigoso; lacínios triangulares a estreitamente triangulares ou estreitamente oblongas, ápice agudo ou arredondado, 0,3-0,5(-1,5) mm compr., 0,2-0,5 mm larg.; corola alva a azul, tubo 2,5-5 mm compr., 0,5-0,9 mm larg. na base, lobos triangulares, raramente largamente deltoides, ápice agudo, 1,5-2 mm compr., 0,7-1,5 mm larg.; filetes ca. 0,2 ou 0,7-0,8 mm compr., anteras 0,82,1 mm compr.; estilete 4-6,2 ou 1,9-3,6 mm compr., estigma $0,3-0,8 \mathrm{~mm}$ compr. Mericarpos glabros a estrigosos 1,5-3,1 mm compr., 1,2-2,6 mm larg.

Material examinado: Congonhas do Norte, Serra do Cipó, estrada Congonhas - Gouveia, $4 \mathrm{~km}$ noroeste de Congonhas do Norte, 1847'53"S, 4342'33"W, M.F. Calió et al. 24, 19.I.2004, fl., fr. (SPF); a 9 km de Gouveia, 18²6'S, $43^{\circ} 44^{\prime} \mathrm{W}$, A. Furlan et al. CFSC 8320, 20.IV.1982, fl., fr. (SPF); 1846'25"S, 4344'18,7"W, M.F. Calió et al. 200, 21.I.2007, fl., fr. (SPF); ca. $10 \mathrm{~km} \mathrm{~N}$ de Congonhas do Norte, 18 46'10"S, 434'45"W, J.R. Pirani et al. 5782, 5.II.2009, fl., fr. (SPF); estrada para Costa Sena, ca. $15 \mathrm{~km}$ de Congonhas do Norte, 18ㄴ2'33,8"S, 434'ㄴ,8"W, M.F. Calió et al. 203, 21.I.2007, fl., fr. (SPF); trilha em direção ao Retiro do Barbado, após a fazenda do Sr. José Correia (Serra Talhada), Serra do Cipó, $18^{\circ} 51$ 'S, $43^{\circ} 45^{\prime} \mathrm{W}$, A. Furlan et al. CFSC 8337, 21.IV.1982, fl., fr. (SPF); Serra Talhada, 6,8 km SW da estrada Congonhas do Norte - Gouveia, entrada a 3,7 km NW de Congonhas do Norte, estrada pelo alto da serra denominada localmente como "Serra do João Camilo", 18 48'40"S, 4345'09"W, J.R. Pirani et al. 5143, 19.I.2004, fl., fr. (K, MBM, SPF); entrada pelo alto da serra em local denominado localmente Retiro dos Pereiras, 18 ${ }^{\circ} 51^{\prime} 40^{\prime \prime S}$, 4344'60"W, J.R. Pirani et al. 5760, 4.II.2009, fl., fr. (SPF); vale do rio Preto, 184' 34,6 "S, 4343'46,6"W, M.F. Calió et al. 176, 19.I.2007, fl., fr. (SPF); idem, 1851'34"S, 4345'27"W, R. Mello-Silva et al. 2409, 20.I.2004, fl., fr. (SPF); $9 \mathrm{~km} \mathrm{~S}$ de Congonhas do Norte na estrada para Conceição de Mato Dentro, estrada para Extrema, seguindo ca. $11 \mathrm{~km}$ - estrada para Lapinha, 18\%56'14,8"S, 4341'06,1"W, M.F. Calió et al. 188, 20.I.2007, fl., fr. (SPF); estrada Congonhas do Norte - Santana do Riacho, Serra da Carapina (Serra Talhada segundo folha do IBGE), 1856'S, 434'W, R.C. Forzza et al. 743, 3.III.1998, fl., fr. (SPF). Jaboticatubas, rodovia Lagoa Santa - Conceição do Mato Dentro - Diamantina, km 110, M. Sazima \& J. Semir CFSC 3831, 16-24.II.1973, fl., fr. (SP, SPF). Santana de Pirapama,

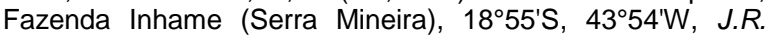
Pirani et al. CFSC 7990, 20.III.1982, fl., fr. (SPF); idem, J.R. Pirani et al. CFSC 8102, 22.III.1982, fl., fr. (SPF); Serra do Cipó (Serra da Lapa), distrito de São José da Cachoeira, Trilha da Senhorinha, 1900'22"S, 4345'20"W, V.C. Souza et al. 32724, 19.II.2007, fl., fr. (ESA, K); Capela de São José, Terreno do Sr. Luiz, perto do Rio das Pedras, 1900'18"S, 4346'34"W, D.C. Zappi et al. 2767, 9.III.2010, fl., fr. (K, SPF); Fazenda Toucan Cipó, subida da Captação de água, 1900'18"S, 4346'06"W, D.C. Zappi et al. 737, 16.II.2007, fl., fr. (K, SPF); idem, 1900'18,5"S, 43ำ4'6,2"W, D.C. Zappi et al. 2434, 18.XI.2009, fl., fr. (K, SPF); idem, 1900'19"S,
43ㄴ5'27"W, D.C. Zappi et al. 2776, 10.III.2010, fl., fr. (K, SPF); Fazenda Toucan Cipó, limite sul da Fazenda, seguindo a cerca, 1900'43,9"S, 4346'5,6"W, D.C. Zappi et al. 2468, 21.XI.2009, fl., fr. (K, SPF); estrada Santana do Riacho Santana de Pirapama, Trilha do Cruzeiro, V.C. Souza et al. 32941, 21.Il.2007, fl., fr. (ESA, K). Santana do Riacho, camino de São José de Almeida a Conceição do Mato Dentro, 9 km SW del Rio Cipó, ca. 1922'S, 433'W, M.M. Arbo et al. 4815, 10.II.1991, fl., fr. (SPF); $7 \mathrm{~km} \mathrm{NE}$ de Cardeal Mota, 1920'S, 4335'W, M.M. Arbo et al. 4642, 8.II.1991, fl., fr. (SPF); $10-20 \mathrm{~km}$ NE de Cardeal Mota, 1920'S, 4335'W, M.M. Arbo et al. 4214, 16.V.1990, fl., fr. (SPF); Parque Nacional da Serra do Cipó, Rodovia MG-010, antigo km 115 (atual km 108), $19^{\circ} 08^{\prime} \mathrm{S}, 43^{\circ} 42^{\prime} \mathrm{W}$, M.F. Calió et al. 7, 8.VI.2002, fl., fr. (SPF); Congonhas, próximo à casa de pedra, M.G.L. Wanderley CFSC 11487, 20.V.1989, fl., fr. (SPF); abaixo da casa de pedra, próximo ao córrego Gavião, $M$. Pereira \& M. Lucca 913, 22.III.1992 (SPF); Serra das Bandeirinhas, A.M. Giulietti CFSC 12554, 27.VII.1991, fl., fr. (SPF); Serra do Cipó, km 106, D.C. Zappi \& C. Kameyama CFSC 9634, 24.III.1986, fl., fr. (SPF); 1917'S, 4336'W, G.M. Faria \& M. Mazucato 9, II.1990, fl., fr. (SPF); km 107, caminho para Usina Dr. Pacífico Mascarenhas, E. Forero et al. CFSC 8992, 7.IX.1980, fl., fr. (SP, SPF); idem, M.C. Henrique et al. CFSC 6870, 9.I.1981, fl., fr. (SP, SPF); idem, J.R. Pirani et al. CFSC 12342, 31.V.1991, fl., fr. (SPF): estrada Lagoa Santa a Conceição do Mato Dentro, km 109 (antigo 114), E. Forero et al. CFSC 8632, 6.IX.1980, fl., fr. (SP, SPF); idem, km 116, S.A.P. Godoy et al. CFSC 9851, 26.VII.1986, fl., fr. (SPF); idem, km 119, próximo à ponte do córrego Palácio, M.C. Henrique \& M.L. Kawasaki CFSC 7636 , 30.X.1981. fl., fr. (SPF); idem, km 110, M.C. Assis \& J.R. Pirani CFSC 11463, 21.V.1989, fl., fr. (SPF); 7-12 km de Santana do Riacho, camino a Lapinha, ca. 1910'S, 434ㄴ'W, M.M. Arbo et al. 4829, 11.Il.1991, fl., fr. (SPF); idem, 190'1"S, 4341'41"W, A. Rapini et al. 590, 4.III.1998, fl., fr. (SPF); APA Morro da Pedreira, Córrego Duas Pontes, ca. 1917'S, 433'', M.F. Calió et al. 13, 9.VI.2002, fl., fr. (SPF); Santana do Riacho, caminho para o Morro do Calcário, $R$. Simão-Bianchini CFSC 11651, 25.I.1990, fl., fr. (SPF); RPPN Brumas do Espinhaço e Ermo do Gerais, C.A. Ferreira Junior et al. 778, 28.XI.2012, fl., fr. (BHZB, SPF); idem, J. Ordones et al. 2083, 26.XI.2012, fl., fr. (BHZB, SPF).

Segundo Kirkbride (1976), D. fruticosa é a espécie de maior distribuição geográfica dentro do gênero, ocorrendo no México, Cuba, América Central, Colômbia, Venezuela, Guiana, Suriname, Bolívia, Paraguai e no Brasil (na Cadeia do Espinhaço, em elevações próximo ao alto Rio São Francisco e raramente no leste da Bahia). No Planalto Central do Brasil é encontrada principalmente em campos rupestres, mas há registros de ocorrência em cerrado. $D$. fruticosa apresenta também a maior amplitude morfológica dentro do gênero, com variações expressivas até mesmo em um único indivíduo (e.g., pubescência e presença ou ausência de pecíolo). As estípulas fortemente decorrentes e os entrenós conspicuamente 2-costelados permitem fácil distinção de $D$. fruticosa dentre as demais espécies com as quais em alguns casos pode ser confundida, como $D$. cordigera e $D$. deltoidea. Coletada em flor e fruto durante $\mathrm{o}$ ano todo. 
11.5. Declieuxia gracilis J.H.Kirkbr., Mem. New York Bot. Gard. 28: 61. 1976.

Fig. 7. I-L.

Erva perene, $12-40 \mathrm{~cm}$ alt.; caule estrigoso, entrenós 7-25 cm compr. Estípulas conspícuas, 1dentadas, base não decorrente, 0,7-1,6 x 0,2-0,4 mm. Folhas opostas ou raramente verticiladas (3-4 folhas por nó), sésseis, sem pares de folhas menores nas axilas; lâmina linear a estreitamente triangular, lanceolada, estreitamente oblonga ou estreitamente elíptica, base cuneada, margem revoluta, ápice agudo a acuminado, 3,8-16 $\mathrm{mm}$ compr., 0,6-1,8 $\mathrm{mm}$ larg., 4,7-18 vezes mais longa que larga, subcoriácea, estrigosa; venação uninérvea, nervuras secundárias inconspícuas. Inflorescências terminais, 13-50 flores pediceladas; pedicelo 0,1-0,3 $\mathrm{mm}$ compr.; hipanto estrigoso a densamente estrigoso; lacínios estreitamente oblongos a oblongos, ápice arredondado, 0,4-1,1 mm compr., 0,2-0,3 mm larg.; corola azul, tubo 2,5-3,3 mm compr., 0,4-0,9 mm larg. na base, lobos triangulares, ápice agudo, 1,5-1,8 mm compr., $0,6-1 \mathrm{~mm}$ larg.; filetes $0,2-0,3$ ou $0,8-1,4 \mathrm{~mm}$ compr; anteras 0,6-0,8 mm compr.; estilete $3,6-4,5$ ou ca. 2,2 mm compr., estigma 0,2-0,8 mm compr. Mericarpos estrigosos, 1,3-2 mm compr., 1,3-2 mm larg.

Material examinado: Jaboticatubas, Serra do Cipó, km 118 (ca. $153 \mathrm{~km} \mathrm{~N}$ of Belo Horizonte), H.S. Irwin et al. 20589, 20.II.1968 (NY isótipos); rodovia Lagoa Santa Conceição do Mato Dentro - Diamantina, km 120, J. Semir \& M.Sazima CFSC 2060, 1.V.1972, fl. (SP); idem, km 121, J. Semir \& A.B. Joly CFSC 3715, 5.I.1973, fl. (SP); idem, km 127, A.B. Joly \& J. Semir CFSC 3245, 22.VIII.1972, fl. (SP); Estrada da Usina, A.B. Joly et al. 2226, 28.V.1972, fl. (SP); a $10 \mathrm{~km}$ da Pensão do Chapéu de Sol, A.B. Joly et al. CFSC 1723, 16.IV.1972, fl. (SP); idem, A.B. Joly et al.CFSC 1677, 16.IV.1972, fl. (SP). Santana do Riacho, Rodovia Lagoa Santa - Conceição do Mato Dentro - Diamantina, km 118 , A.B. Joly et al. CFSC 1777, 16.IV.1972 fl., fr. (SP); idem, km 119,5, A.B. Joly et al. CFSC 1789, 16.IV.1972, fl., fr. (SP); idem, km 121, J. Semir \& A. M. Joly CFSC 3739, 5.I.1973, fl., fr. (SP); Estrada da Usina, c. $10 \mathrm{~km}$ da entrada da estrada principal, A.B. Joly \& J. Semir CFSC 3027, 21.VIII.1972, fl. (SP); APA do Morro da Pedreira, córrego Duas Pontes, 1200 $\mathrm{m}$ alt., ca. 1917'S, 4334'W, M.F. Calió et al. 12, 9.VI.2002, fl., fr. (SPF); M.F. Calió et al. 14, 9.VI.2002, fl., fr. (SPF).

Declieuxia gracilis é endêmica da Serra do Cipó (Kirkbride 1976) e diferencia-se facilmente das demais espécies por seu hábito herbáceo, sua fragilidade (folhas extremamente quebradiças), entrenós longos quando comparados ao comprimento das folhas e também por sua folhagem esparsa.

11.6. Declieuxia humilis (Müll.Arg.) J.H.Kirkbr., Mem. New York Bot. Gard. 28: 61. 1976.

Erva perene 4-10 cm alt., com sistema subterrâneo desenvolvido; caule estrigoso, entrenós 3-
$9 \mathrm{~mm}$ compr. Estípulas conspícuas, 1-dentadas, base não decorrente, $(0,2-) 0,3-0,5(-0,7) \mathrm{mm}$ compr. Folhas verticiladas (3-4 folhas por nó), sésseis, raramente com 1-4 pares de folhas menores nas axilas; lâmina estreitamente elíptica a linear, base cuneada, margem levemente revoluta, ápice agudo, 10-15 mm compr., 1$1,8 \mathrm{~mm}$ larg., 5,6-13,5 vezes mais longa que larga, subcoriácea, glabra; venação uninérvea, nervuras secundárias inconspícuas. Inflorescências terminais e axilares, 25-65 flores pediceladas; pedicelo 0,1-0,3 $\mathrm{mm}$ compr.; hipanto glabro; lacínios oblongos a estreitamente oblongos, ápice agudo, 0,2-0,4 mm compr., 0,1-0,2 mm larg.; corola azul, tubo 2,1-3 mm compr., ca. 0,5 mm larg. na base, lobos triangulares a largamente ovados, ápice agudo, 1,4-2 mm compr., 0,6-1,6 mm larg.; filetes 0,7-1 mm compr; anteras ca. 0,7 mm compr.; estilete ca. 1,7 ou 4,4 mm compr., estigma não observado. Fruto desconhecido.

Material examinado: Minas Gerais, A. Glaziou 9474 (G holótipo; C, K isótipos); A. Glaziou 16115 in Herb. Warming (C).

Declieuxia humilis, originalmente descrita como uma variedade de $D$. oenanthoides Mart. \& Zucc. ex Schult. \& Schult. f., é uma espécie muito rara, conhecida apenas pelas coleções-tipo (Kirkbride 1976). Assemelha-se a $D$. irwinii pelo hábito diminuto, mas distingue-se dessa pelas estípulas conspícuas e folhas sésseis com venação uninérvea. Difere de $D$. gracilis principalmente devido às folhas mais densamente dispostas e entrenós mais curtos.

11.7. Declieuxia irwinii J.H.Kirkbr., Mem. New York Bot. Gard. 28: 49. 1976.

Fig. 7. N.

Erva perene 4-13 cm alt., com sistema subterrâneo desenvolvido; caule estrigoso, entrenós 1$5 \mathrm{~mm}$ compr. Estípulas inconspícuas (reduzidas a uma saliência). Folhas opostas ou verticiladas (3 folhas por nó), pecioladas; pecíolo alado, até $1 \mathrm{~mm}$ compr., raramente 1-2 pares de folhas menores nas axilas; lâmina estreitamente elíptica, base atenuada, margem revoluta, ápice agudo,11-18 mm compr., 1,5-4,5 mm larg., 2,8-7,5 vezes mais longa que larga, subcoriácea, concolor, glabra a estrigosa nas margens próximo à base; venação broquidódroma, nervuras secundárias visíveis apenas na face abaxial. Inflorescências terminais, 2-32 flores pediceladas; pedicelo 0,2-1 mm compr.; hipanto estrigoso, raramente glabro; lacínios estreitamente oblongos ou estreitamente triangulares, ápice arredondado, 0,3-0,8 mm compr., 0,1-0,2 mm larg.; corola azul, tubo 3,7-4,4 mm compr., 0,7-0,8 mm larg. na base, lobos triangulares, ápice agudo, 1,7-3 mm compr., 0,9-1,5 mm larg.; filetes ca. 0,2 ou 1-2 mm compr; anteras 0,8-1 mm compr.; estilete 6-6,4 ou 2,2- 
3,7 mm compr., estigma 0,4-0,6 mm compr. Mericarpos estrigosos, 1,4-2,3 mm compr., 1,1-1,9 mm larg.

Material examinado: Jaboticatubas, Serra do Cipó, rodovia Lagoa Santa - Conceição do Mato Dentro Diamantina, km 114, J. Semir \& M. Sazima CFSC 2796, 24.VII.1972, fl. (SP); idem, km 114, J. Semir \& M. Sazima CFSC 3397, 6.IX.1972, fl., fr. (SP); idem, km 127, J. Semir et al. CFSC 2768, 23.VII.1972, fl. (SP); idem, km 128, A.B. Joly \& J. Semir CFSC 2980, 20.VIII.1972, fl. (SP); idem, km 135, J. Semir \& M. Sazima CFSC 3368, 5.IX.1972, fl. (SP); idem, km 138-9, A.M. Joly \& C. Müller CFSC 3438, 8.IX.1972, fl. (SP); idem, km 142, A.B. Joly \& J. Semir CFSC 3162, 22.VIII.1972, fl. (SP). Santana de Pirapama, Serra do Cipó, acesso pela Faz. Inhame, Trilha da Senhorinha, 1856'14"S, 4344'36", D.C. Zappi \& N.P. Taylor 2255, 27.VII.2009, fl. (K, SPF). Santana do Riacho, Alto do Palácio, próximo à sede do IBAMA, J.R. Pirani et al. CFSC 12709, 1.IX.1991, fl., fr. (SPF); Parque Nacional da Serra do Cipó, Serra da Bandeirinha, próximo à casa do IBDF, D.C. Zappi et al. CFSC 10523, 9.IX.1987, fl. (SP, SPF); idem, A.M. Giulietti et al. CFSC 12514, 27.VII.1991, fl. (SPF); Rodovia Belo Horizonte Conceição do Mato Dentro, km 138, Alto do Palácio, T.B. Cavalcanti et al. CFSC 9899, 12.IX.1986, fl., fr. (SPF); idem, $\mathrm{km} 109$ (antigo 114), E. Forero et al. 7720 [CFSC 8649], 6.IX.1980, fl. (SP, SPF); idem, E. Forero et al. 7721 [CFSC $8650], 6 . I X .1980$ (SP, SPF); idem, km 111, C. Kameyama \& D.C. Zappi CFSC 9856, 1.IX.1986, fl. (SPF); idem, km 134, I. Cordeiro et al. CFSC 7530, 6.X.1981, fl. (SPF); idem, km 115, perto do Córrego 2 Pontinhas, N.L.Menezes CFSC 6554, 7.IX.1980, fl. (SP); Fazenda Cachoeira da Capivara, V.C. Souza \& N.L. Menezes CFSC 11612, 5.IX.1989, fl. (SPF). Sem município, Serra do Cipó, 18.II.1972, W.R. Anderson et al. 36255 (K, NY, US isótipos).

Declieuxia irwinii é endêmica da Serra do Cipó (Kirkbride 1976), sendo encontrada em solos arenosos dos campos rupestres. Diferencia-se da maioria das espécies principalmente por seu tamanho diminuto. Se comparada a $D$. humilis e $D$ muscosa A.St.-Hil., que também apresentam porte pequeno, diferencia-se da primeira pelas estípulas inconspícuas e folhas pediceladas com venação broquidódroma, e da segunda principalmente por apresentar caule estrigoso e inflorescências com 2 ou mais flores. Foi encontrada florida entre julho e outubro e com frutos apenas em setembro.

11.8. Declieuxia Ieiophylla Müll.Arg., Flora 59(28): 438.1876.

Fig. 7. $\mathrm{M}$.

Erva perene, 9-25 cm alt.; caule glabro, entrenós 3-16 mm compr. Estípulas conspícuas, 1dentadas, base decorrente, 1,4-7,7 x 0,1-0,3 mm. Folhas opostas, sésseis, sem pares de folhas menores nas axilas; lâmina estreitamente elíptica, base cuneada, margem plana, levemente espessada, ápice agudo a acuminado, 14,5-55 mm compr., 2,5-11 mm larg., 2,3-7 vezes mais longa que larga, subcoriácea, concolor, glabra; venação broquidódroma, nervuras salientes na face abaxial. Inflorescências terminais, 30-60 flores pediceladas; pedicelo ca. 0,2 mm compr.; hipanto glabro; lacínios estreitamente oblongos a oblongos, ápice agudo a arredondado, 0,3-1,1 mm compr., 0,1-0,3 mm larg.; corola azul, tubo 3,5-6,4 mm compr., 0,6-1,5 mm larg. na base, lobos ovados a estreitamente oblongos, ápice agudo, 2,0-3,5 mm compr., 0,8-1,5 mm larg.; filetes ca. $0,2-0,8$ ou ca. 1,5 $\mathrm{mm}$ compr; anteras 1,0-1,3 mm compr.; estilete ca. 3,2-3,5 ou 5-6,3 mm compr., estigma $0,3-0,7 \mathrm{~mm}$ compr. Mericarpos glabros, 2,1-2,5 mm compr., 1,52,0 mm larg.

Material examinado: Santana de Pirapama, Fazenda Inhame (Serra Mineira), $18^{\circ} 55^{\prime} \mathrm{S}, 43^{\circ} 54^{\prime} \mathrm{W}, \mathrm{I}$. Cordeiro et al. CFSC 8218, 24.III.1982, fl., fr. (SPF); J.R. Pirani et al. CFSC 8110, 22.III.1982, fl. (SPF). Sem município, Serra da Lapa, Riedel 1079, XI.1824 (G fragmento do holótipo, F e K isótipos).

Declieuxia leiophylla é uma espécie muito rara, endêmica da Serra do Cipó, sendo conhecida apenas por três coleções, uma delas o espécime-tipo (Kirkbride 1976). É bastante semelhante a D. fruticosa, diferenciando-se da mesma principalmente por ser uma erva perene e pela presença de folhas frequentemente de menor largura, mas mais longas do que os entrenós. Coletada com flor e fruto no mês de março.

11.9. Declieuxia muscosa A.St.-Hil., Voy. distr. diaman 1: 365. 1833.

Erva perene, $2-6 \mathrm{~cm}$ alt., formando pequenas moitas; caule glabro, entrenós 0,5-3 mm compr. Estípulas incospícuas ou conspícuas, 1-dentadas, base não decorrente, ca. 0,2 x 0,08 mm. Folhas opostas, pecioladas, pecíolo alado, sem pares de folhas menores nas axilas; lâmina subcoriácea, base longamente atenuada, margem plana, levemente espessada, elíptica a estreitamente elíptica, ápice agudo a acuminado, 3-6,5 mm compr., 0,6-1,5 mm larg., 2,4-5 vezes mais longa que larga, subcoriácea, concolor, glabra; venação uninérvea a eucamptódroma, nervuras laterais pouco conspícuas. Flores solitárias, sésseis; hipanto glabro, lacínios estreitamente triangulares, ápice agudo, 0,3-0,6 mm compr., 0,1-0,2 mm larg.; corola azul, tubo 3,7-4,5 mm compr., 0,4-0,8 mm larg. na base, lobos elípticos a ovados, ápice agudo, 1,5-2,5 mm compr., 1,1-1,5 mm larg.; filetes 0,3-0,5 ou ca. 1,5 mm compr.; anteras 0,6$0,75 \mathrm{~mm}$ compr.; estilete 2,6 ou 5,6-7,5 mm compr., estigma 0,2-1 mm compr. Mericarpos glabros, 1,5-2,1 $\mathrm{mm}$ compr., 1-1,5 mm larg.

Material examinado: Santana do Riacho, Serra do Cipó, trilha do Travessão, 1919'51,9"S, 4331'28"W, G.M. Antar \& P.M. Gonella 325, 10.XI.2013, fl. (SPF). 
Material adicional: Diamantina, estrada para Conselheiro Mata, a $8 \mathrm{~km}$ da rodovia BR 259, R. Mello-Silva et al. 311, 18.III.1990, fl., fr. (SPF); $6 \mathrm{~km}$ da estrada CurveloDiamantina, 1816'S, 43\%49'W, R. Harley et al. 25438, 30.X.1988, fl., fr. (SPF); Datas, estrada Diamantina-Curvelo a $21 \mathrm{~km}$ de Diamantina, N.L. Menezes et al. CFCR 2647, 01.XI.1981, fl. fr. (SPF); km 185, estrada Diamantina Conselheiro Mata, N.L. Menezes \& V.C. Souza CFCR 12315 , 9.IX.1989, fl. fr. (SPF).

Declieuxia muscosa era conhecida apenas da região de Diamantina (Kirkbride 1976), entretanto foi recentemente coletada na Serra do Cipó. Em campo, diversos indivíduos compõem um tapete de pequenas moitas, sendo essa a característica mais marcante dessa espécie.

11.10. Declieuxia passerina Mart. \& Zucc. ex Schult. \& Schult.f., Mant. 3: 112. 1827.

Fig. 7. O.

Subarbusto $15-77 \mathrm{~cm}$ alt; caule estrigoso a densamente estrigoso, entrenós 1-7 mm compr. Estípulas inconspícuas (reduzidas a uma saliência). Folhas opostas ou verticiladas, adpressas ao caule, sésseis, sem pares de folhas menores nas axilas; lâmina oval a lanceolada, base truncada ou cordada, margem revoluta, ápice acuminado, 5-10 mm compr., 1-4 mm larg., 2,1-6,6 vezes mais longa que larga, subcoriácea, concolor, secando enegrecida, glabra a densamente estrigosa; venação broquidódroma, com nervuras basais fortemente arqueadas. Flores solitárias ou em inflorescências terminais ou axilares com 3 flores pediceladas; pedicelo 0,2-0,8 mm compr.; hipanto estrigoso; lacínios triangulares a estreitamente triangulares ou estreitamente oblongas, ápice agudo a arredondado, 0,2-0,3 mm compr., 0,02-0,2 mm larg.; corola azul, tubo 3,4-4,7 mm compr., 0,5-1 mm larg. na base, lobos triangulares a estreitamente triangulares, ápice agudo 1,5-2,7 mm compr., 0,6-1,2 mm larg.; filetes ca. 0,2 ou $0,9-1,2 \mathrm{~mm}$ compr., anteras $0,5-1 \mathrm{~mm}$ compr.; estilete $3,5-5,5$ ou 2-2,5 mm compr., estigma 0,1-1 $\mathrm{mm}$ compr. Mericarpos estrigosos a esparsamente estrigosos, 1,7-2 mm compr., 1,3-2 mm larg.

Material examinado: Congonhas do Norte, Estrada Congonhas - Gouveia, a $9 \mathrm{~km}$ de Gouveia, $18^{\circ} 46^{\prime} \mathrm{S}$, 434'W, A. Furlan et al. CFSC 8318, 20.IV.1982, fl., fr. (SPF); Serra Talhada (setor nordeste da Serra do Cipó), $6,8 \mathrm{~km}$ SW da estrada Congonhas do Norte - Gouveia, entrada a $3,7 \mathrm{~km} \mathrm{NW}$ de Congonhas do Norte, início da estrada rumo ao Retiro dos Pereiras, ca. $3 \mathrm{~km}$ da ponte sobre o córrego Congonhas, 184' 34,6 "S, 43눈'46,6"W, M.F. Calió et al. 175, 19.I.2007, fl., fr. (SPF). Jaboticatubas, rodovia Lagoa Santa - Conceição do Mato Dentro - Diamantina, km 126, A.B. Joly et al. CFSC 1977, 17.IV.1972, fl. (SP); idem, km 134, A.B. Joly \& J. Semir CFSC 3654, 3.XI.1972, fl. (SP). Santana de Pirapama,
Fazenda Inhame (Serra Mineira), $18^{\circ} 55^{\prime} \mathrm{S}, 43^{\circ} 54^{\prime} \mathrm{W}, J . R$. Pirani et al. CFSC 8107, 22.III.1982, fl., fr. (SPF). Santana do Riacho, Rodovia Belo Horizonte - Conceição do Mato Dentro, km 125, J.C.C. Gonçalves et al. CFSC 9377, 1.XI.1985, fl., fr. (SPF). Sem município, Serra do Cipó, W.R. Anderson et al. 36404, 20.II. 1972, fl., fr. (SP).

Declieuxia passerina ocorre apenas entre a região sul do Planalto de Diamantina (Gouveia) até o norte/noroeste da Serra do Cipó (Kirkbride 1976), em campo rupestre. Distingue-se facilmente das demais espécies por seu hábito herbáceo e pequenas folhas adpressas ao caule. Diferencia-se de $D$. cordigera var. cordigera pelas estípulas inconspícuas e pequenas inflorescências axilares com no máximo três flores. Coletada em flor e fruto de fevereiro a abril e em novembro.

11.11. Declieuxia saturejoides Mart. \& Zucc. ex Schult. \& Schult.f., Mant. 3: 111. 1827.

Fig. 7. P.

Subarbusto $15-50 \mathrm{~cm}$ alt.; caule estrigoso, entrenós 3-6 mm compr. Estípulas conspícuas, 1-3dentadas, linear triangulares a estreitamente triangulares, base não decorrente, 0,3-0,6(-1,2) x 0,1$0,2 \mathrm{~mm}$. Folhas opostas, pecioladas; pecíolo alado, até $1 \mathrm{~mm}$ compr., com 2-3 pares de folhas menores nas axilas; lâmina linear a estreitamente elíptica, base atenuada, margem revoluta, ápice agudo a arredondado,5,5-13 mm compr., 0,7-3 mm larg., 3,79,3 vezes mais longa que larga, cartácea, estrigosa; venação uninérvea ou eucamptódroma, nervuras evidentes apenas na face abaxial. Inflorescências terminais, 7-24 flores pediceladas; pedicelo 0,1-0,3 $\mathrm{mm}$ compr.; hipanto estrigoso, raramente papiloso; lacínios triangulares ou oblongos, ápice arredondado, 0,2-0,5 mm compr., 0,2-0,3 mm larg.; corola alva a azul, tubo 2,5-4,1 mm compr., 0,4-0,6 mm larg. na base, lobos triangulares, ápice agudo, 1,2-2,2 mm compr., $0,5-1 \mathrm{~mm}$ larg.; filetes $0,2-0,3$ ou $0,5-0,6 \mathrm{~mm}$ compr., anteras 0,8-1 mm compr.; estilete $3,2-4,2$ ou 1,7-2,5 mm compr., estigma 0,3-1,1 mm compr. Mericarpos estrigosos a esparsamente estrigosos, raramente papilosos, 1,0-1,8 $\mathrm{mm}$ compr., 0,9-1,8 mm larg.

Material examinado: Jaboticatubas, Serra do Cipó, rodovia Lagoa Santa - Conceição do Mato Dentro Diamantina, km 127, J. Semir \& M. Sazima CFSC 736, 7.Il.1972, fl., fr. (SP, SPF). Santana de Pirapama, trilha da captação da Fazenda Toucan Cipó, Capela São José, 1900'22"S, 4345'21"W, D.C. Zappi et al. 2148, 15.III.2009, fl. (K, SPF); idem, 1900'22"S, 434ㄴ' $20 " \mathrm{~W}$, D.C. Zappi et al. 799, 16.II.2007, fl., fr. (K, SPF); acesso pela Faz. Inhame, Trilha do João Carrinho, 1902'55"S, 4344'14"W, D.C. Zappi et al. 1561, 25.II.2009, fl. (K, SPF); idem, 1902'51,2"S, 4343'51,7"W, D.C. Zappi et al. 2405, 16.XI.2009, fl., fr. (K, SPF). Santana do Riacho, 
Serra do Cipó, rodovia MG 010, km 124, a nordeste da Sede do IBAMA, 1908'S, 4342'W, M.F. Calió et al. 4, 8.VI.2002, fl., fr. (SPF); idem, km 122, J.R. Pirani \& M.C. Assis CFSC 11441, 20.V.1989, fl., fr. (SPF); idem, km 123, R. Simão-Bianchini CFSC 11506, 21.V.1989, fl., fr. (SPF); idem, km 125, J.R. Pirani et al. CFSC 12690, 29.VII.1991, fl., fr. (SPF); idem, km 138, B. Stannard et al. CFCR 6030, 15.XI.1984, fl., fr., (SPF); Alto do Palácio, F.R. Salimena-Pires et al. CFSC 11429, 15.IV.1989, fl., fr. (SPF); APA do Morro da Pedreira, 1915'S, 433' W, J.R. Pirani et al. 6016, 12.VII.2009, fl., fr. (SPF); estrada Santana do Riacho - Lapinha, 190'ㄱ' $17^{\prime \prime S}, 43^{\circ} 41^{\prime} 41$ "W, A. Rapini et al 591, 4.III.1998, fl., fr. (SPF); Morro do Breu, 1904'20"-05'20"S, 4339'20"-40'20"W, N. Hensold 454 CFSC 8538, 16-17.II.1982, fl., fr. (SPF).

Declieuxia saturejoides apresenta distribuição na Cadeia do Espinhaço, em Minas Gerais (Kirkbride 1976). Pode ser facilmente identificada pelo hábito muito ramificado, com aspecto de árvores em miniatura, com entrenós curtos e folhas diminutas. Encontrada com flores e frutos praticamente 0 ano inteiro.

11.12. Declieuxia spergulifolia Mart. \& Zucc. ex Schult. \& Schult.f., Mant. 3: 111. 1827.

Fig. 7. Q.

Subarbusto $25-50 \mathrm{~cm}$ alt.; caule glabro, entrenós 5-47 mm. Estípulas conspícuas, 1-dentadas, linear-triangulares ou estreitamente triangulares, base decorrente, 1,6-2,4 x 0,2-0,6 mm. Folhas opostas, pecioladas; pecíolo alado, pecíolo 1-2 mm compr., com 1-3 pares de folhas menores nas axilas; lâmina estreitamente elíptica a linear, base longamente atenuada, margem revoluta, ápice agudo a acuminado, 14-30 mm compr., 2-4 mm larg., 3,5-11,5 vezes mais longa que larga, cartácea, glabra; venação broquidódroma, nervuras secundárias evidentes apenas na face abaxial. Inflorescências terminais, 0,9$1,3 \mathrm{~cm}$ compr., 13-18(60) flores pediceladas; pedicelo 0,2-0,6 mm compr.; hipanto glabro ou papiloso; lacínios largamente deltoides ou triangulares, ápice obtuso ou agudo, 0,2-0,3 mm compr., ca. 0,2 mm larg.; corola azul, tubo 3-4 mm compr., 0,6-1,5 mm larg. na base, lobos triangulares, ápice agudo a obtuso, 1-1,7 $\mathrm{mm}$ compr., 0,5-1 mm larg.; filetes $0,1-0,2$ ou 1,5 mm compr., anteras 0,8-1 mm compr.; estilete $4-4,1$ ou 3,2 $\mathrm{mm}$ compr., estigma 0,3-0,6 mm compr. Mericarpos papilosos, 1-1,8 mm compr., 1-1,8 $\mathrm{mm}$ larg.

Material examinado: Congonhas do Norte, Serra da Mangabeira, A. Furlan et al. CFSC 8453, 23.IV.1982, fl., fr. (SPF); Serra da Carapina, 1852'12"S, 4344'14"W, J.R. Pirani et al. 4114, 2.III.1998, fl., fr. (SPF); Serra Talhada, alto da Serra do João Camilo, 6,8 km sudoeste da estrada Congonhas do Norte - Gouveia, entrada a $3,7 \mathrm{~km}$ noroeste de Congonhas do Norte, Fazenda Vereda do Cambota, 1848'39"S, 4345'09"W, R. Mello-Silva et al. 2374, 10.I.2004, fl., fr. (MBM, SP, SPF); idem, M.F. Calió et al. 23, 19.I.2004, fl., fr. (SPF); idem, estrada pelo alto da serra em local denominado localmente Retiro dos Pereiras, 1850'60"S, 4344'60"W, J.R. Pirani et al. 5747, 4.II.2009, fl., fr. (SPF). Santana de Pirapama, Fazenda Inhame (Serra Mineira), I. Cordeiro et al. CFSC 8151, 23.III.1982, fl., fr. (SPF); idem, estrada velha para a mina de manganês, 185'30"S, 4347'21"W, 1212m, D.C. Zappi et al. 2355, 13.XI.2009, fl., fr. (K, SPF); estrada São José da Cachoeira - Inhame, trilha da Senhorinha, 1900'00"S, 4345'47"W, D.C. Zappi et al. 827, 19.Il.2007, fl., fr. (ESA, K); Capela de São José, Trilha da Senhorinha, caminho a Congonhas do Norte, 1857'36,5"S, 4344'13,7"W, D.C. Zappi et al. 2529, fl., fr. (K, SPF).

Declieuxia spergulifolia tem distribuição na Cadeia de Espinhaço (região de Diamantina e apenas um registro nas proximidades de Caetés (Kirkbride 1976), com ocorrência também na porção noroeste da Serra do Cipó (Congonhas do Norte e Santana de Pirapama), sendo encontrada em fendas de rochas. Pode ser facilmente identificada pelo caule multiramificado, estípulas decorrentes e folhas cartáceas com folhas menores nas axilas. Esses caracteres relacionados às folhas permitem a sua diferenciação em relação à $D$. fruticosa. Distingue-se de $D$. diantheroides pela ausência de indumento nos ramos e pelas folhas estreitas. Foi coletada em flor e fruto nos meses de março, abril e novembro.

\section{Diodella Small}

Ervas ou subarbustos perenes ou anuais, eretos ou prostrados, glabros ou pilosos; ramos tetragonais. Estípulas interpeciolares fimbriadas, adnatas à base das folhas, glabras ou pubescentes. Folhas opostas, sésseis ou pecioladas, glabras ou pubescentes. Inflorescências subterminais a axilares, cimosas (raramente espigas) ou flores solitárias; flores bissexuadas, actinomorfas, alvas, rosadas ou lilases; lacínios 2-4, iguais ou desiguais, base livre ou levemente conata; corola com prefloração valvar, infundibuliforme (2-)4-lobada, glabra ou pubescente, prefloração valvar; estames 4 , inseridos na região da fauce da corola, anteras versáteis, dorsifixas; ovário bicarpelar, bilocular, lóculos uniovulados; estigma inteiro capitado. Fruto esquizocarpo seco com 2 mericarpos indeiscentes; sementes 2, obovais, comprimidas ou levemente cilíndricas, presas ao septo na face ventral, sulcadas ao redor do estrofíolo.

Bacigalupo \& Cabral (2006, 2007b) segregaram em Diodella sete espécies previamente incluídas no gênero Diodia L. (5 spp.) com base em uma série de características. Diodella apresenta estigma inteiro, corola infundibuliforme, sementes com face ventral sulcada e mericarpos indeiscentes, caducos, enquanto Diodia tem estigma bífido, corola hipocrateriforme e mericarpos que permanecem unidos mesmo quando o fruto está maduro. Apenas espécies de Diodella foram registradas na Serra do Cipó. 
1. Folhas densamente pilosas a escabras, com nervuras secundárias evidentes, ápice não aristado

1'. Folhas glabras a pilosas, não escabras, com nervuras secundárias inconspícuas ou pouco conspícuas, ápice aristado.

2. Plantas com folhas aproximadas na porção distal, subtendendo ramos laterais curtos; ramos geralmente excedendo $40 \mathrm{~cm}$ compr., caules com 3-5 mm diâm. 12.2. Diodella mello-barretoi

2'. Plantas com folhas regularmente dispostas ao longo dos ramos, pouco ramificadas; ramos atingindo $30 \mathrm{~cm}$ compr., caules até $2 \mathrm{~mm}$ diâm.

3. Plantas eretas; folhas com margem plana a espessada

12.1. Diodella apiculata

3 '. Plantas decumbentes ou prostradas; folhas com margem revoluta 12. 4. Diodella teres

12.1. Diodella apiculata (Willd ex. Roem. \& Schult.) Delprete, Flora llustrada Catarinense RUBI I: 169. 2005.

Diodia apiculata (Willd. ex Roem. \& Schult.) K.Schum., Bot. Jahrb. Syst. 10: 313. 1889.

Fig. 4. F-G.

Ervas ou subarbustos eretos, 0,3-0,5 m alt.; ramos 1,5-2 mm diâm., rígido, castanho-claro, cilíndrico, hirsuto a estrigoso. Estípulas glabras a pubescentes, $5-10 \times 3 \mathrm{~mm}, 7-9$ fimbriadas. Folhas opostas, regularmente dispostas ao longo dos ramos, sésseis; lâmina lanceolada a estreitamente-oval, base auriculada a truncada, margem espessada, ápice agudo, aristado, 1-1,5(-2,5) cm compr., 3-6 mm larg., coriácea, secando amarelada, geralmente glabra, por vezes apresentando tricomas esparsos, longos; venação uninérvea, nervuras secundárias inconspícuas em ambas as faces. Inflorescências axilares, 1-3-floras; flores sésseis; hipanto 1,5-2 mm compr., ca. $1 \mathrm{~mm}$ larg.; lacínios desiguais, bordo serreado, persistentes no fruto; corola lilás a rosada, hipocrateriforme, 4-lobada, 8-12 mm compr., 2-4 mm larg.; anteras azuladas. Mericarpos globosos a obovoides, levemente rugosos, esparsamente pubérulos, ca. $5 \mathrm{~mm}$ compr., ca. $3 \mathrm{~mm}$ larg.; sementes obovais.

Material examinado: Congonhas do Norte, $13 \mathrm{~km} \mathrm{NW}$ de Congonhas do Norte, caminho a Gouveia, aprox. $18^{\circ} 41$ 'S $43^{\circ} 42^{\prime}$ W, M.M. Arbo et al. 5002, 13.Il.1991, fl., fr. (CTES, SPF). Jaboticatubas, Serra do Cipó, Estrada da Usina, J. Semir \& A.M. Joly CFSC 3805, 7.I.1973, fl. (SP); $10 \mathrm{~km}$ da Pensão Chapéu de Sol, A.B. Joly et al. CFSC 1511, 15.IV.1972, fl. (SP); idem, A.B. Joly et al. CFSC 1711, 16.IV.1972, fl. (SP); rodovia Lagoa Santa - Conceição do Mato Dentro - Diamantina, km 110, J. Semir et al. CFSC 2819, 24.VII.1972, fl., fr. (SP, UEC); idem, km 112, A.B. Joly et al. CFSC 974, 4.III.1972, fl. (SP); idem, A.B. Joly et al. CFSC 1033, 5.III.1972, fl., fr. (SP); idem, km 112,5, A.B. Joly CFSC 1450, 15.IV.1972, fl., fr. (SP); idem, km 113, J. Semir \& M. Sazima CFSC 661, 7.II.1972, fl., fr. (SP); idem, km 115 , A.B. Joly et al. CFSC 826, 4.III.1972, fl., fr. (SP); idem, A.B. Joly et al. CFSC 833, 4.III.1972, fl., fr. (SP); idem, A.B. Joly et al. CFSC 844, 4.III.1972, fl., fr. (SP); idem, km 116, A.B. Joly et al. CFSC 98, 6.VI.1970, fl. (SP); idem, km 118, A.B. Joly et al. CFSC 1776, 16.IV.1972, fl. (SP). Santana de Pirapama, Serra do Cipó, Capela de São José, Trilha da Senhorinha,

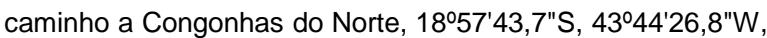
D.C. Zappi et al. 2526, 25.XI.2009, fl., fr. (K, SPF); Fazenda Toucan Cipó, estrada para a Captação, 1900'18"S, 43ㄴ6'06"W, D.C. Zappi et al. 716, 15.II.2007, fl., fr. (K, SPF); acesso pela Faz. Inhame, Trilha para Senhorinha, 185'46"S, 4345'30"W, D.C. Zappi et al. 1852, 8.III.2009, fr. (K, SPF). Santana do Riacho, estrada Belo HorizonteConceição do Mato Dentro, Estrada da Usina, V.C. Souza et al. 28572, 28.II.2002, fl., fr., (ESA); rodovia Belo Horizonte Conceição do Mato Dentro, km 100, M.G.L. Wanderley 52, 25.III.1977, fl., fr. (SP); 7 km ENE de São José de Almeida, na estrada para Conceição do Mato Dentro, $19^{\circ} 26^{\prime} \mathrm{S}$, 43ํํ'W, Arbo et al. 4785, 10.II.1991, fl., fr. (CTES, SPF).

Material adicional: Minas Gerais, Grão-Mogol, estrada Grão Mogol-Cristália, I.Cordeiro et al. CFCR 936, 15.IV.1981, fl. (K, SPF); idem, margem da estrada Grão Mogol-Montes Claros em direção sudoeste, campo sujo, $16^{\circ} 35^{\prime}$ S, $42^{\circ} 53^{\prime} \mathrm{W}, \mathrm{N}$. Hensold et al. CFCR 3506, 23.V.1982, fl., fr. (K, SPF).

Espécie neotropical, ocorrendo principalmente em lugares secos, em solos arenosos ou graníticos, apresenta grande variabilidade, o que dificulta a delimitação do táxon (Steyermark 1972). Essa variabilidade é expressa principalmente na presença ou não de tricomas, na morfologia dos caules e frutos, bem como na forma, disposição e pilosidade das folhas. Na Serra do Cipó, cresce em campo rupestre sobre solo arenoso e pedregoso, florescendo e frutificando entre janeiro e março.

12.2. Diodella mello-barretoi (Standl.) Bacigalupo \& E.L.Cabral, Darwiniana 44(1): 100. 2006.

Diodia mello-barretoi Standl., Publ. Field Mus. Nat. Hist., Bot. Ser. 22: 113. 1940.

Fig. 4. $\mathrm{H}$.

Arbustos com sistema subterrâneo espessado; ramos eretos, (0,3-)0,4-1 m alt., 3-5 mm diâm., rígidos, cilíndricos, castanho-claros, velutinos. Estípulas 8-12, levemente pubescentes, 6-10 x 3-6 mm, fimbriadas. Folhas opostas, concentradas no ápice dos ramos, subtendendo ramos laterais curtos, sésseis; lâmina lanceolada a oval, base auriculada, margem espessada, ápice agudo, aristado, 1,5-2,5 cm compr., 3-10 mm larg., coriácea, secando amarelada, glabra exceto nas margens; venação uninérvea, nervuras 
secundárias inconspícuas em ambas as faces. Inflorescências axilares no ápice do ramo principal e nos ramos laterais, 1-3-floras; flores sésseis; hipanto 4-5 mm compr., ca. 1,5 mm larg.; lacínios 4-5, desiguais, persistentes no fruto; corola rosa, hipocrateriforme, 4-lobada, 7-9 mm compr., 4-6 mm larg., estames exsertos. Fruto não observado.

Material examinado: Jaboticatubas, Serra do Cipó, rodovia Lagoa Santa - Conceição do Mato Dentro Diamantina, km 110, M Sazima \& J. Semir CFSC 3837, 16 a 24.II.1973, fl. (SP, UEC); idem, km 112, J. Semir \& M. Sazima CFSC 704, 7.II.1972, fl. (SP, UEC); idem, km 113, A.B. Joly et al. CFSC 1523, 15.IV.1972, fl., fr. (SP, UEC); idem, km 115, A.B. Joly et al. CFSC 871, 4.III.1972, fl. (SP, UEC); idem, km 118, A.B. Joly et al. CFSC 974, 4.III.1972, fl., fr. (UEC); idem, km 126, A.B. Joly et al. CFSC 1081, 5.III.1972, fl. (SP, UEC). Santana do Riacho, Serra do Cipó, $A$. Duarte 7647, 14.II.1963, fl. (RB); idem, J.G. Kuhlmann 26, 16.I.1951, fl. (RB); idem, E. Pereira 8823, 15.III.1964, fl. (RB); idem, about $5 \mathrm{~km}$ down the road to the Cachoeira and Serra

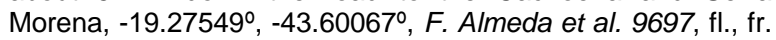
(UEC); idem, km 105, Irwin et al. 20361, 17.II.1968, fl., fr. (K, NY, UB); idem, km 130, A. Duarte 2261, 10.XII.1949, fl. (RB); idem, km 132, Irwin et al. 20225, 16.Il.1968, fl., fr. (K, NY, UB); idem, km 132, A. Duarte 6521, 15.III.1962, fl. (RB); idem, km 133, H. Mello Barreto 1280, 15.IV.1935, fl. (RB); idem, J.F.B.M. Campos 1, 19.XII.1966, fl., fr. (SPF); estrada Belo Horizonte-Conceição do Mato Dentro, km 106, W. Mantovani et al. CFSC 7745, 16.Il.1982, fl., fr. (SPF); idem, Zappi \& Kameyama CFSC 9632, 24.III.1986, fl., fr. (SPF); $19^{\circ} 17^{\prime} \mathrm{S}, 43^{\circ} 36^{\prime} \mathrm{W}$, G. Faria \& M. Mazucato 10, II.1990, fl., fr. (SPF); idem, km 111, H.L. Wagner et al. CFSC 9554, 26.I.1986, fl., fr. (SPF); estrada para Lapinha, 1908'17"S, 4341'41"W, J.R. Pirani et al. 4216, 5.III.1998, fl., fr. (SPF); idem, J.R. Pirani et al. CFSC 12161, 27.III.1991, fl., fr. (SPF); 7-12 km N de Santana do Riacho, caminho a Lapinha, ca. 1910'S, 4341'W, M.M. Arbo et al. 4863, 11.II.1991, fl., fr. (CTES, SPF); APA do Morro da Padreira, estrada da Usina Dr. Pacífico Mascarenahs (ramal da Rodovia MG010), além do Rio Capivara rumo ao Vau da Lagoa, terras de propriedade da Companhia Cedro \& Cachoeira, próximo à porteira da propriedade de José Aécio Drumond, 1912'59,7"S, 4336'13,4"W, J.R. Pirani et al. 5997, 11.VII.2009, fl. (SPF).

Espécie endêmica da Serra do Cipó (Bacigalupo \& Cabral 2006), ocorre geralmente em altitudes superiores a $1100 \mathrm{~m}$. Diferencia-se das outras espécies de Diodella por meio de seu hábito robusto, com folhas aproximadas em direção ao ápice dos ramos, subtendendo ramos laterais abundantes. Floresce de dezembro a abril.

12.3. Diodella radula (Willd. \& Hoffmans. ex Roem. \& Schult.) Delprete, Flora llustrada Catarinense RUBI I: 174. 2005.

Diodia radula (Willd. \& Hoffmans. ex Roem. \& Schult.) Cham. \& Schltdl., Linnaea 3: 342. 1828.

Fig. 4. I.

Ervas até $80 \mathrm{~cm}$ alt., perenes; ramos 2-2,5 mm diâm., eretos, tetragonais, acastanhados, densamente pilosos. Estípulas 9-10(-15), hirsutas, persistentes, 5-7 $x$ 4-6 mm, fimbriadas. Folhas opostas, regularmente dispostas ao longo dos ramos, sésseis a curtamente pecioladas; pecíolo 0-1 $\mathrm{mm}$ compr.; lâmina elíptica a oval-lanceolada, base cuneada a arredondada, margem escabra, ápice agudo, mucronado, 2,5-4 cm compr., (1-)1,5-2,2 cm larg., membranácea, escabra, pubescente; venação eucamptóroma, nervuras salientes na face abaxial, impressas na face adaxial. Inflorescências axilares, 5-8-floras; flores sésseis, 4meras, hipanto 1-2 mm compr., ca. $1 \mathrm{~mm}$ larg., lacínios subiguais, estreito-triangulares, pilosos, ciliados, persistentes no fruto; corola alva a rosada, pilosa no ápice, 8-10 mm compr., ca. $4 \mathrm{~mm}$ larg.; estames inseridos na região da fauce da corola. Mericarpos obovoides, pilosos, 2-3 mm compr., 2-3 $\mathrm{mm}$ larg.; sementes obovais.

Material examinado: Jaboticatubas, Serra do Cipó, atrás da sede do IBAMA, L.S. Kinoshita \& J.Y. Costa 00/142, 21.XI.2000, fr. (UEC); idem, K. Yamamoto \& M.F. Freitas 00/78, 21.XI.2000, fl. (UEC). Santana de Pirapama, Serra do Cipó, Fazenda Toucan Cipó, estrada para a captação, D.C. Zappi et al. 714, 15.Il.2007, fl., fr.(ESA, HUEFS, K, SPF); Capela de São José, terreno do Sr. Luiz, perto do Rio das Pedras, 1900'18"S, 4346'34"W, D.C. Zappi et al. 2772, 9.III.2010 (SPF, K). Santana do Riacho, caminho para a Lapinha, 1910'S, 43ㄴ1'W, M.M. Arbo et al. 4886, 11.II.1991, fl., fr. (CTES, SPF).

Diodella radula ocorre no Peru, Equador e, no Brasil, nos estados do Pará, Ceará, Bahia, Minas Gerais, Rio de Janeiro, São Paulo e no sul do país (Barbosa et al. 2014). Na Serra do Cipó, foi coletada em solo arenoso à beira de rio, florescendo e frutificando em fevereiro e março.

12.4. Diodella teres (Walt.) Small, FI. Lancaster Co.: 271. 1913.

Diodia teres Walt., FI. Carol. 87. 1788.

Ervas 10-50 cm alt; ramos 1,5-2 mm diâm., glabros ou pilosos, prostrados ou semi-eretos. Estípulas 7, pilosas, 5-10 × $3 \mathrm{~mm}$, fimbriadas. Folhas opostas, regularmente dispostas ao longo dos ramos, sésseis; lâmina linear a linear-lanceolada, base truncada a levemente auriculada, ciliada, margem fortemente revoluta, não espessada, ápice aristado, 1,4-2 cm compr., 1-4 mm larg., cartácea, pilosa a glabrescente; venação eucamptódroma, nervuras secundárias pouco conspícuas ou inconspícuas em ambas as faces. Inflorescências axilares, 1-3-floras; flores sésseis; hipanto 1,8-2 mm compr., ca. 1,2 mm larg.; lacínios levemente desiguais, margem serreada, persistentes no fruto; corola alva com ápice rosado, infundibuliforme, 4-lobada, 6-7 mm compr., 2-4 mm larg. Mericarpos ovoides, costados, levemente rugosos, 
glabros, 4 mm compr., 3 mm larg.; sementes obovais.

Material examinado: Santana do Riacho, Serra do Cipó, estrada para a Cachoeira da Farofa, R. SimãoBianchini CFSC 11682, 27.I.1990, fl., fr. (SPF); estrada Belo Horizonte - Conceição do Mato Dentro, km 117, A. Furlan et al. CFSC 7207, 19.IV.1981, fl., fr. (SPF).

Material adicional: Minas Gerais: Grão-Mogol, Fazenda Francisco Sá, córrego da Bonita, $16^{\circ} 35^{\prime} \mathrm{S}, 42^{\circ} 56^{\prime} \mathrm{W}, 700 \mathrm{~m}$ M.T.V.A. Campos et al. CFCR 13311, 5.IX.1990 (SPF).

Amplamente distribuída desde o sul dos Estados Unidos, México, Caribe, até o sudeste do Brasil, Bolívia e Paraguai (Govaerts 2013). Na Serra do Cipó, foi coletada em cerrado e campo rupestre, florescendo e frutificando de janeiro a abril.

\section{Emmeorrhiza Pohl ex Engl.}

Lianas, ramos tetragonais, volúveis, delgados, esparsamente pilosos. Estípulas interpeciolares fimbriadas, decíduas, concrescidas formando um tubo. Folhas opostas, curtamente pecioladas, levemente pubérulas, com nervuras subparalelas. Inflorescências terminais e axilares, em panículas amplas de umbelas simples; flores bissexuadas, actinomorfas, 4-meras; lacínios denticulados; corola com prefloração valvar, curtamente campanulada, estames 4, exsertos ou inclusos; ovário bilocular, lóculos uniovulados, estigma bífido. Fruto capsular; sementes oblongas.

13.1. Emmeorrhiza umbellata (Spreng.) K.Schum. in Mart., Eichler \& Urb., FI. bras. 6(6): 408. 1889.

Fig. 5. B.

Erva volúvel; ramos delicados, glabros a pilosos. Estípulas 10-15 x 3-5 mm, 3-7-fimbriadas. Folhas curtamente pecioladas; pecíolo 1-2,5 mm compr.; lâmina elíptico-lanceolada, base atenuada, margem plana, ápice acuminado, (2-)4-6(-7) cm compr., (0.7-)1,5-2,5 cm larg., cartácea, discolor, face abaxial secando verde-olivácea clara, esparsamente pubérula, face adaxial verde-olivácea escura, glabra; venação eucamptódroma, nervuras secundárias levemente na face abaxial. Flores pedunculadas; hipanto turbinado, 4-lobado, 0,5-1 mm compr., ca. 0,5 $\mathrm{mm}$ larg.; corola alva a alva-esverdeada, às vezes com máculas vináceas, ca. $1 \mathrm{~mm}$ compr., ca. $1 \mathrm{~mm}$ larg. Cápsula castanho-clara, turbinada, $3 \mathrm{~mm}$ compr., $2 \mathrm{~mm}$ larg.; sementes $2 \mathrm{~mm}$ compr., aladas.

Material examinado: Jaboticatubas, Serra do Cipó, rodovia Lagoa Santa - Conceição do Mato Dentro Diamantina, km 120, A.B. Joly et al. CFSC 4509, 18.X.1973, fl., fr. (SP, UEC); idem, J. Semir et al. CFSC 4410, 5.IX.1973, fl. (SP, UEC). Santana do Riacho, Parque Nacional da Serra do Cipó, lado oposto a Estátua do Juquinha, E.A. Anunciação 227, 2.V.1993, fl., fr. (SP); Serra da Bandeirinha, Parque
Nacional da Serra do Cipó, I. Cordeiro et al. CFSC 10547, 9.IX.1987, fl. (F, SP, SPF); APA Morro da Pedreira, MG 010, $\mathrm{km}$ 112, Córrego Duas Pontinhas, L.R. Lima et al. 79, 25.IX.1999, fl. (SPF); km 107, caminho para Usina Dr. Pacífico Mascarenhas, E. Forero et al. 7989 [CFSC 8902], 7.IX.1980, fl., fr. (SP); RPPN Brumas do Espinhaço e Ermo do Gerais, C.A. Ferreira Junior 652, 13.IX.2012, fl. (BHZB, SPF).

Material adicional: Minas Gerais: Caparaó, abaixo do Parque Nacional, J.R. Pirani et al. 2546, 24.X.1989, fl., fr. (SPF); Itabirito, L. Krieger 10674, 10.VI.1971, fl., fr. (CESJ, K). São Paulo: Mogi Guaçu, Fazenda Campininha, E. Forero et al. 8428, 24.IX.1980, fl., fr. (SP, SPF).

A espécie ocorre da Colômbia até a Argentina. No Brasil, ocorre nos estados da Bahia, Espírito Santo, Minas Gerais, Rio de Janeiro, São Paulo e Santa Catarina (Barbosa et al. 2014). Na Serra do Cipó, foi coletada no interior de mata ciliar, florescendo em setembro.

\section{Faramea Aubl.}

Árvores ou arbustos, frequentemente glabros. Estípulas interpeciolares triangulares, conatas ou não na base, ápice aristado a subulado, proeminente. Folhas opostas, pecioladas, frequentemente azuladas quando jovens. Inflorescência terminal ou subterminal, corimbosa ou axilar, em cimeiras, ou raramente flores axilares solitárias. Flores bissexuadas, actinomorfas, 4-meras, sésseis ou pediceladas; hipanto turbinado, truncado ou com lobos triangulares a lineares; corola com prefloração valvar, hipocrateriforme, lobos frequentemente reflexos, azul, violácea ou alva,; estames 4, subsésseis; ovário unilocular, uniovulado; estigma bífido, com um ramo mais curto que o outro. Drupa indeiscente, globosa; pirênio com semente horizontal, globosa a oblata.

14.1. Faramea nigrescens Mart., Flora 24(2): 73. 1841.

Fig. 6. C-D.

Arvoretas ou arbustos 2-10 m alt. Estípulas conatas, não escariosas, 5-12 x 5-8 mm, moderadamente a longamente aristadas. Folhas pecioladas, pecíolo 5-10 mm compr.; lâmina oblongoelíptica a oval, base arredondada a obtusa, margem com espessamento amarelado, levemente revoluta, ápice arredondado, abruptamente acuminado, $5-12 \mathrm{~cm}$ compr., 3-6 cm larg., firmemente cartácea a subcoriácea, discolor, face abaxial verde-clara, face adaxial brilhante, secando verde-escura a enegrecida com nervuras amareladas; venação broquidódroma, nervuras e reticulo salientes em ambas as faces, domácias ausentes. Inflorescências corimbosas, pedunculadas, ramificadas. Flores pediceladas; hipanto vináceo, subgloboso com tubo truncado a 
levemente denteado, 2-3 mm compr., 1,5-2 mm larg.; corola com tubo alvo e lobos violáceos a azulados, ca. $1,5 \mathrm{~cm}$ compr., ca. $2 \mathrm{~mm}$ larg. Drupas azul-escuras a atropurpúreas, 4-5 $\mathrm{mm}$ compr.

Material examinado: Jaboticatubas, Serra do Cipó, km 117, M.S.F. Silvestre 9064, 2.XI1978, fl. (UEC). Santana de Pirapama, Fazenda Inhame, 1855'S, 4354'W, J.R. Pirani et al. CFSC 8019, 21.III.1982, fr. (SPF). Santana do Riacho, Parque Nacional da Serra do Cipó, E.A. Anunciação 207, 1.V.1993, fr. (SP); rodovia Belo Horizonte-Conceição do Mato Dentro, km 105, Córrego Chapéu de Sol, J.R. Pirani CFSC $6671,14 . X .1980$ fl. (SPF); Estrada da Usina, N.M. Castro et al. CFSC 9407, 1.XI.1985, fl. (BHCB, F, HUEFS, K, MBM, SP, SPF); idem, F.A. Vitta 636, 12.II.1999, fr. (UEC); Vale do Córrego Andrequicé, A. Furlan et al. CFSC 6729, 8.XI.1980, fl. (SP, SPF); descida da Serra das Bandeirinhas, A.M. Giulietti et al. CFSC 12594, 28.VII.1991, fr. (SPF); estrada para Lapinha, $4 \mathrm{~km}$ de Santana do Riacho, C.F. Muniz et al. CFSC 7901, 18.II.1982, fr. (SP, SPF); RPPN Brumas do Espinhaço e Ermo do Gerais, J. Ordones et al. 2037, 26.XI.2012, fl., fr. (BHZB, SPF).

Material adicional: Minas Gerais: Lima Duarte, RPPN Serra Negra, J.A.Oliveira et al. 18, 26.X.2008, fl. (CESJ, K).

Faramea nigrescens é restrita ao Brasil, ocorrendo na Bahia, Minas Gerais, Distrito Federal, Goiás e Tocantins (Barbosa et al. 2014). Na Serra do Cipó, ocorre em matas ciliares. Floresce em outubronovembro e frutifica de fevereiro a julho.

\section{Galianthe Griseb.}

Ervas, subarbustos ou arbustos pouco ramificados, perenes; ramos cilíndricos ou tetragonais, glabros ou pubescentes. Estípulas interpeciolares conatas, fimbriadas, glabras ou pubescentes, adnatas às folhas caulinares. Folhas opostas ou falsamente verticiladas, glabras ou pubescentes. Inflorescências em cimeiras corimbiformes terminais, expandidas; flores bissexuadas, actinomorfas, 4-meras; corola com prefloração valvar, infundibuliforme; estames 4, inseridos na região da fauce da corola; estigma capitado ou bipartido; ovário bicarpelar, bilocular, lóculos uniovulados. Fruto capsular seco, turbinado, constituído de 2 carpelos de deiscência longitudinal que permanecem unidos na base; sementes 2, foveoladas, às vezes sulcadas transversalmente.

\section{Chave para as espécies}

1. Folhas $5-11 \mathrm{~cm}$ compr., lanceoladas

1 . Folhas 0,5-4 cm compr., lineares a estreitamente lanceoladas.

2. Pedúnculo da inflorescência até $2 \mathrm{~cm}$ compr., pouco mais longo que as folhas

15.2. G. grandifolia

2'. Pedúnculo da inflorescência 3-10 cm compr., ultrapassando as folhas

15.3. G. peruviana 15.1. G. angustifólia

15.1. Galianthe angustifolia (Cham. \& Schltdl.) E.L. Cabral, Bol. Soc. Argent. Bot. 27: 2391991 [publ. 1992].

Fig. 4. J-K.

Ervas $50-80 \mathrm{~cm}$ alt., com sistema subterrâneo espessado; ramos eretos, levemente quadrangulares, fistulosos, castanho-avermelhados, pilosos, entrenós $2-8 \mathrm{~cm}$ compr. Estípulas adnatas às duas folhas do nó, persistentes, 5-6-fimbriadas, pubérulas, 5-8 x 4-7 mm. Folhas opostas, sésseis, com ramos axilares curtos presentes que conferem aparência de folhas verticiladas; lâmina linear ou estreitamente lanceolada, base atenuada, margem revoluta, ápice agudo, (1-)2-4 cm compr., 2-5(-6) mm larg., membranácea, glabra a diminutamente pilosa; venação uninérvea, nervuras secundárias inconspícuas. Inflorescência tirsoide, multiflora, pedunculada; pedúnculos $3-10 \mathrm{~cm}$ compr.; flores sésseis, heterostílicas; hipanto $2,5 \mathrm{~mm}$ compr., $1,2 \mathrm{~mm}$ larg., lacínios triangulares, agudos; corola alva, infundibuliforme, externamente glabra, 4-5 mm compr., lobos da corola internamente pilosos; estilete 2,5-3,5 mm compr., estigma bifurcado. Cápsulas castanho-escuras, glabras, 4-4,5 mm compr., 2,5-3 $\mathrm{mm}$ larg.; sementes $2,5 \mathrm{~mm}$ compr.
Material examinado: Santana do Riacho, Serra do Cipó, km 149 na estrada de Conceição [do Mato Dentro], Mello Barreto 8496, 25.XI.1938, fl. et 8986, 6.II.1938, fr. (BHCB).

Material adicional: Minas Gerais: Claussen s.n., 1840, fr. (K); Glaziou 8164, s.d., fl. (K); Joaquim Felício, Serra do Cabral, estrada Joaquim Felício - Várzea da Palma, 15,5 km além da ponte sobre o Córrego da Onça, 17\%44'53"S, 44ำ15'41"W, M.F. Calió et al. 54, 26.I.2004, fl., fr. (SPF). São Paulo: São Paulo, Bosque da Saúde, J. Semir s.n., 25.I.1968 (SPF).

Galianthe angustifolia ocorre em Minas Gerais, São Paulo e Goiás (Barbosa et al. 2014). Na Serra do Cipó, foi coletada em campo com cascalho, em flor em novembro e frutificando em fevereiro. Não se conhecem registros recentes desta espécie na área da Serra do Cipó.

15.2. Galianthe grandifolia E.L. Cabral, Bonplandia 7(1-4): 14. 1993.

Fig. 4. L.

Erva 0,5-1,5 m alt., com sistema subterrâneo espessado; ramos eretos, cilíndricos a levemente quadrangulares, fistulosos, não-ramificados, lisos, 
castanho-avermelhados, entrenós 5-12 cm compr. Estípulas adnatas às duas folhas do nó, persistentes, 6-7-fimbriadas, pubérulas, $10-15 \times 5-8 \mathrm{~mm}$. Folhas opostas, sésseis; lâmina lanceolada, base atenuada, margem plana, ápice agudo, 5-11 cm compr., 10-30 $\mathrm{mm}$ larg., membranácea, glabra a pubescente, sobretudo nas nervuras da face abaxial; venação eucamptódroma, nervuras secundárias subparalelas evidentes em ambas as faces. Inflorescência tirsoide, multiflora, ampla, longamente pedunculada, pedúnculo 5-8 cm compr.; flores sésseis, heterostílicas; hipanto 2 $\mathrm{mm}$ compr., 1,2 mm larg., 4-denteado, lobos triangulares, agudos; corola alva, infundibuliforme, externamente papilosa, 3,5-5 $\mathrm{mm}$ compr., lobos da corola internamente pilosos; estilete 2,5-3,5 mm compr., estigma bifurcado. Cápsulas ferrugíneas com tricomas adpressos, ca. $5 \mathrm{~mm}$ compr., 2,5-3 mm larg.; sementes imaturas $2,5 \mathrm{~mm}$ compr.

Material examinado: Congonhas do Norte, Serra Talhada, fazenda Vereda do Cambota, alto da Serra do João Camilo, 6,8 km sudoeste da estarda Congonhas do Norte Gouveia, entrada a 3,7 km noroeste de Congonhas do Norte, 1848'39"S, 4345'09"W, M.F. Calió et al. 27, 19.l.2004, fl. (MBM, SP, SPF); $13 \mathrm{~km} \mathrm{NW}$ de Congonhas do Norte, caminho a Gouveia, aprox. 18넌, $43^{\circ} 42^{\prime}$ W, M.M. Arbo et al. 5019, 13.II.1991, fl., fr. (SPF). Santana do Riacho, Serra da Lapinha, NW da Serra do Cipó, Lapinha, J.R. Pirani et al. CFSC 12172, 27.III.1991, fl. (SPF).

Material adicional: Minas Gerais: Botumirim, várzea do Ribeirão da Estiva, M.G. Carvalho 458, 25.VII.1991, fr. (CETEC, SPF); Diamantina, $7 \mathrm{~km}$ NE of town towards Mendanha, H.S. Irwin et al. 22835, 29.I.1969, fl. (K, NY); Grão-Mogol, estrada para o Rio ventania, ca. 16언, 4249'W, M.T.V.A. Campos et al. CFCR 13349, 5.IX.1990, fl., fr. (SPF); Joaquim Felício, Serra do Cabral, V.C. Souza et al. 25574, 10.VII.2001, fl. (ESA, SPF); ca. $15 \mathrm{~km}$ W de Joaquim Felício, caminho a Várzea de Palma, aprox. 17은' 4417'W, M.M. Arbo et al. 4581, 20.V.1990, fl., fr. (SPF); Retiro, ca. $11 \mathrm{~km}$ da cidade em direção a Mato Verde, ca. 2 $\mathrm{km}$ do Rio Mandaçaia, 1522'41"S, 4241'54"W, C.M. Sakuragui et al. CFCR 15138, 17.III.1994, fl. (SPF).

Galianthe grandifolia ocorre em Minas Gerais, Distrito Federal, Goiás e Mato Grosso (Barbosa et al. 2014). Na Serra do Cipó, foi registrada apenas no setor nordeste (Serra Talhada) e sudoeste (Serra da Lapinha), coletada em campo, sobre solo arenosopedregoso, florescendo em janeiro, março e julho.

15.3. Galianthe peruviana (Pers.) E.L. Cabral, Bonplandia 10(1-4): 123. 2000.

G. corymbosa (Ruiz \& Pav.) E.L. Cabral, Bol. Soc. Argent. Bot. 27(3-4): 241. 1991 [publ. 1992].

Fig. 4. M-N.

Arbustos ou subarbustos $30-50 \mathrm{~cm}$ alt; ramos cilíndricos, muito ramificados, com ritidoma escamoso, entrenós 0,3-1,5 cm compr. Estípulas adnatas às duas folhas do nó, persistentes, pubérulas, 2-5 x 1-4 mm.
Folhas sésseis, falsamente verticiladas; lâmina linear a estreitamente lanceolada, base atenuada, margem revoluta, ápice agudo, 0,5-2 cm compr., 1-3 mm larg., coriácea, glabra; venação uninérvea, nervuras secundárias inconspícuas. Inflorescência em cimeiras multifloras terminais; pedúnculo até $2 \mathrm{~cm}$ compr., ligeiramente mais longo que as folhas; flores sésseis, alvas a alvo-esverdeadas, $3-5 \mathrm{~mm}$ compr., $2-3 \mathrm{~mm}$ larg.; lacínios pubérulos; estigma bilobado. Cápsulas pubérulas, ca. $3 \mathrm{~mm}$ compr., ca. $2 \mathrm{~mm}$ larg.; sementes lisas, castanhas, adaxialmente sulcadas, ca. 2,2-2,3 $\mathrm{mm}$ compr., 0,8-1 $\mathrm{mm}$ larg.

Material examinado: Congonhas do Norte, Serra Talhada (braço Norte da Serra do Cipó, 1850'26"S, 4344'53"W, J.R. Pirani et al. 5159, 19.I.2994, fl., fr. (K, SPF); Serra da Mangabeira, margem direita do Rio Preto, 1850'S, 4349'W, fr., A. Furlan et al. CFSC 8455, 23.IV.1982, fl. (CTES, SPF). Jaboticatubas, Serra do Cipó, estrada da Usina, A.B. Joly et al. CFSC 2292, 28.V.1972, fl., fr. (SP, UEC); -c. $10 \mathrm{~km}$ da entrada da estrada principal, A.B. Joly \& J. Semir CFSC 3078, 21.VIII.1972, fl. (SP); caminho da base do IBAMA no Rio Cipó para o Capão dos Palmitos, J.R. Pirani et al. CFSC 11961, 25.III.1991, fl. (SPF); idem, $R$. Simão-Bianchini \& S. Bianchini CFSC 12749, 31.V.1991, f1., fr. (SPF); rodovia Lagoa Santa - Conceição do Mato Dentro Diamantina, km 114, A.M. Giulietti \& N. Menezes CFSC 3991, 26.II.1973, fl. (SP); idem, A.B. Joly et al. CFSC 1561, 15.IV.1972, fl. (SP); idem, A.B. Joly et al. CFSC 2497, 29.V.1972, fl., fr. (SP, UEC); idem, J. Semir \& M. Sazima CFSC 2647, 20.VII.1972, fl. (SP); idem, J. Semir \& M Sazima CFSC 2788, 24.VII.1972, fl., fr. (SP, UEC); idem, J. Semir et al. CFSC 4060, 29.IV.1973, fl., fr. (UEC); idem, J. Semir \& M. Sazima CFSC 4288, 22.VI.1973, fl., fr. (SP, UEC); idem, km 115, J. Semir \& M. Sazima CFSC 601, 15.XII.1971, fl. (SP, UEC); idem, J. Semir et al. CFSC 791, 4.III.1972, fl. (SP, UEC); idem, A.B. Joly CFSC 866, 4.III.1972, fl. (SP, UEC); idem, J. Semir \& A.M. Joly CFSC 3695, 4.I.1973, fl., fr. (SP, UEC); idem, km 116, A.B. Joly et al. CFSC 76, 6.VI.1970, fl. (SP); idem, J. Semir \& M. Sazima CFSC 714, 7.II.1972, fl. (SP, UEC); idem, km 118, A.B. Joly et al. CFSC 932, 4.III.1972, fl., fr. (SP, UEC); idem, km 118, A.B. Joly CFSC 966, 4.III.1972, fl., fr. (SP); idem, A.B. Joly et al. CFSC 969, 4.III.1972, fl., fr. (SP, UEC); idem, km 121, J. Semir \& A.M. Joly CFSC 3714, 4.I.1973, fl. (SP, UEC); idem, km 122, J. Semir \& M. Sazima CFSC 561, 14.XII.1971, fl., fr. (SP, UEC). Santana de Pirapama, Fazenda Inhame, 185' S, 435' W, J.R. Pirani et al. CFSC 7989, 20.III.1982, fl. (F, SPF); Serra do Cipó, Fazenda Toucan Cipó, estrada para a captação, D.C. Zappi et al. 785, 16.II.2007, fl., fr. (ESA, HUEFS, K, SPF); Serra do Cipó, Capela de São José, Terreno do Sr. Luiz, perto do Rio das Pedras, 1900'18"S, 4346'34"W, D.C. Zappi et al. 2774, 9.III.2010, fl., fr. (K, SPF). Santana do Riacho, $7 \mathrm{~km}$ NE de Cardeal Mota em direção a Conceição do Mato Dentro, 1920'S, 4335'W, M.M. Arbo et al. 4597, 8.Il.1991, fl., fr. (CTES, SPF); 10-20 km de Cardeal Mota, M.M. Arbo et al. 4153, 15.V.1990, fl., fr., (CTES, SPF); idem, M.M. Arbo et al. 4167, 15.V.1990 fl., fr. (CTES, SPF); 7-12 km de Santana do Riacho, estrada para Lapinha, 19 $10^{\circ} \mathrm{S}$, $43^{\circ} 41^{\prime}$ W, M.M. Arbo et al. 4896, 11.II.1991, fl. (CTES, SPF); Serra da Lapinha, maciço NW da Serra do Cipó, próximo da localidade da Lapinha, a ca. $50 \mathrm{~km}$ da rodovia Belo Horizonte - Conceição do Mato Dentro, J.R. Pirani et al. CFSC 12168, 27.III.1991, fl. (SPF); idem, J.R. Pirani et al. CFSC 12176, 
27.III.1991, fl., fr. (SPF); idem, J.R. Pirani et al. CFSC 12176A, 27.III.1991, fl., fr. (SPF); norte de Santana do Riacho em direção a São José da Cachoeira, trilha do João Carrinho, 19,0480 S, 43,7387 W, V.C. Souza et al. 32665, 18.II.2007, fl. (ESA, K); km 106 na estrada Belo-Horizonte-Conceição do Mato Dentro, 1917'S, 4336'W, G.M. Faria \& M. Mazucato 54, 1990 (SPF); km 11 (antigo 116) da estrada Lagoa Santa a Conceição do Mato Dentro, E. Forero et al. 7868 [CFSC 8781], 6.XII.1980, fl. (SP); antigo km 115, Kitakawa et al. s.n. SPF 129190, 28.I.1998 fl., fr. (SPF); km 115 ao longo da rodovia Lagoa Santa - Conceição do Mato Dentro Diamantina, N.L. Menezes CFSC 6236, 8.VI.1980, fl., fr. (SP); Serra da Bandeira, W. Mantovani et al. CFSC 7792, 17.II.1982, fl. (SPF); RPPN Brumas do Espinhaço e Ermo do Gerais, J. Ordones et al. 2088, 26.XI.2012, fl. (BHZB, SPF).

Material adicional: Minas Gerais: Gouveia, 44 km SW da cidade, 18ㅇ's, 440.'W, M.M. Arbo et al. 4511, 20.V.1990, fr. (CTES, SPF).

Galianthe peruviana ocorre no Peru, Bolívia, Argentina e no Brasil, onde é encontrada nos estados de Goiás, Minas Gerais e São Paulo. Na Serra do Cipó (Barbosa et al. 2014), a espécie ocorre em campo rupestre, em vegetação transicional entre campo e cerrado e nas proximidades de cursos d'água. Foi coletada em flor e fruto de janeiro a agosto.

\section{Galium L.}

Ervas prostradas, decumbentes, semiescandentes ou eretas, anuais ou perenes, com ramos quadrangulares, glabros a vilosos principalmente nos vértices. Folhas e estípulas geralmente semelhantes, formando verticilos de 4-8 geralmente; lâmina com glândulas translúcidas na face abaxial, 1-3-nervada. Inflorescência paniculada, terminal ou axilar; flores dotadas de brácteas involucrais; flores bissexuadas ou unissexuadas em uma mesma planta, geralmente 4meras; hipanto com tubo truncado ou ausente; corola com prefloração valvar, rotácea, alvo-amarelada, esverdeada, lilás ou vermelha; estames 4; ovário 2locular, lóculos uniovulados. Bagas suculentas com 1 2 mericarpos, alvas, amareladas, avermelhadas ou vináceas; sementes convexas, ventralmente escavadas.

16.1. Galium noxium (A.St.-Hil.) Dempster. Allertonia 5: 292. 1990.

Fig. 5. C.

Ervas prostradas, semi-escandentes ou decumbentes, ultrapassando $50 \mathrm{~cm}$ compr.; ramos quadrangulares, dotados nos vértices de tricomas estrigosos de ca. $1 \mathrm{~mm}$ compr.. Estípulas semelhantes às folhas. Folhas 4-verticiladas, sésseis a curtamente pecioladas; pecíolo $2 \mathrm{~mm}$ compr.; lâmina elíptica, oval ou oboval, base arredondada a truncada, margem plana, ápice arredondado a mucronado, 7-16(-20) mm compr., 5-11(-13) mm larg., cartácea, concolor, glabra a estrigosa, com tricomas concentrados sobre as nervuras; venação acródroma, nervuras proeminentes em ambas as faces. Inflorescências axilares, 1-3 por axila; pedúnculo 2-6 $\mathrm{mm}$ compr., viloso; flores solitárias, sésseis, dotadas de 4 brácteas ovais; hipanto $1 \mathrm{~mm}$ compr., arredondado, tubo ausente; corola alva, lilás a azulada, actinomorfa, rotácea, 1,5 $\mathrm{mm}$ compr., 2-2,2 mm larg; estilete muito curto. Bagas 4-5 mm diâm., glabras, mericarpos 2, alvos; semente 1 por mericarpo, $2 \mathrm{~mm}$ compr., oblonga.

Material examinado: Santana do Riacho, Serra do Cipó, retiro do Alto Palácio, $25 \mathrm{~km}$ NE de Cardeal Mota caminho a Conceição do Mato Dentro, M.M. Arbo et al. 4953, 12.II.1991, fl., fr. (SPF).

Material adicional: Bahia: Rio de Contas, Pico das Almas, campo do Queiroz, 1332'S, 4157'W, R.M. Harley et al. 26656, 28.XI.1988, fr. (SPF). Minas Gerais: Mariana, limite com Ouro Preto, Pico do Itacolomi, 2026'S, 4327'W, G. Eiten 7060-A, 20.XI.1965, fl. (K, UB); $10 \mathrm{~km}$ sudoeste de Diamantina, W.R. Anderson et al. 35254, 3.II.1972, fl., fr. (K, NY, UB); $17 \mathrm{~km}$ a nordeste de Diamantina, estrada para Mendanha, H.S. Irwin et al. 22857, 29.I.1969, fl., fr. (K, NY); $18 \mathrm{~km}$ a leste de Diamantina, H.S. Irwin et al. 27698, 16.III.1970, fl., fr. (K, NY); Serra do Caparaó, L. Krieger et al. 14158, 9.VII.1976, fl., fr. (CESJ, K).

De ampla distribuição na América do Sul (Govaerts 2013), na Serra do Cipó foi coletada apenas a subespécie típica, enquanto Galium noxium ssp. valantioides (Cham. \& Schltdl.) Dempster, que possui folhas mais estreitas e com tricomas maiores, ocorre mais ao sul, de São Paulo até o Paraguai, Uruguai e Argentina. Na Serra do Cipó, foi coletada apenas uma vez, com flores e frutos, no mês de maio.

\section{Genipa L.}

Arbustos a árvores atingindo mais de $8 \mathrm{~m}$; ramos cilíndricos, com folhas opostas agrupadas no ápice. Estípulas inteiras, triangulares, agudas, decíduas. Folhas opostas, sésseis a pecioladas. Flores odoríferas, unissexuadas (em plantas dioicas), actinomorfas, 5-6-meras, em inflorescências cimosas, as femininas solitárias no ápice dos ramos; hipanto turbinado, com tubo bem desenvolvido, truncado ou denteado; corola com prefloração contorcida, hipocrateriforme a infundibuliforme, externamente serícea; estames das flores masculinas depositando o pólen sobre o estigma (apresentação secundária do pólen); ovário 4-5 locular. Bagas carnosas, até $10 \mathrm{~cm}$ compr., globosas a ovoides, coroadas pelo cálice persistente; epicarpo acastanhado, liso ou escamosoferrugíneo; sementes numerosas, comprimidas, envoltas em polpa doce e aromática. 
17.1. Genipa americana L., Syst. Nat. ec. 10, 2: 931. 1759.

Nomes populares: genipapo, genipapinho (Zappi 2007).

Fig. 1. F.

Árvores até $8 \mathrm{~m}$ alt.; ramos castanho-claros, ritidoma desprendendo-se facilmente. Estípulas 8-12 $\mathrm{x}$ 5-8 $\mathrm{mm}$, presentes apenas na gema apical. Folhas sésseis a pecioladas; pecíolo 0-5 mm compr., 2-2,5 mm larg.; lâmina oboval a espatulada, base cuneada, decorrente, margem plana, ápice agudo a acuminado, (15-)18-35 cm compr., 4-13 cm larg., cartácea, concolor, secando enegrecida, glabra; venação eucamptódroma, nervuras secundárias 10-16(-18) de cada lado, salientes na face abaxial, impressas na face adaxial. Inflorescência masculina 6-20-flora, feminina geralmente uniflora; flores 5-meras; hipanto nas flores masculinas campanulado, nas flores femininas urceolado, com tubo truncado a irregularmente lobado ou crenado; corola hipocrateriforme, 10-15 $\mathrm{mm}$ compr., tubo da corola externamente seríceo, creme a amarelado, passando a acastanhado quando velho, lobos reflexos, espatulados, recobrindo o hipanto; estames adnatos à porção mediana do tubo, estigma exserto. Baga até 10 $\mathrm{cm}$ diâm., externamente ferrugínea, coberta de escamas diminutas; sementes 10-12 mm.

Material examinado: Itambé do Mato Dentro, Santana do Rio Preto (Cabeça de Boi), APA do Parque Nacional da Serra do Cipó, após a ponte sobre o Rio Preto, nas terras do José Agostino, 1924'04,1"S, 4324'02,7"W, M.F. Santos \& E.G. Martins 178, 26.VIII.2007, fr. (SPF). Santana de Pirapama, Serra do Cipó, Rio das Pedras, proximidades da ponte do Rio das Pedras, 1901'28,8"S, 43ํ4'58"W, D.C. Zappi et al. 2406, 17.XI.2009, fl., fr. (K, RB, SPF). Santana do Riacho, na entrada da cidade, L.S. Kinoshita \& K. Yamamoto 03/218, 7.XII.2003, fl. (UEC).

Material adicional: São Paulo: Pariquera-Açu, L.C. Bernacci 1016, I.1995, fl. (IAC, K); Pedregulho, Parque Estadual das Furnas do Bom Jesus, núcleo Chapadão, $A . B$. Junqueira et al. 19, 8.VII.2003, fr. (SPF).

Espécie amplamente distribuída na Região Neotropical, ocorrendo no interior dos estados do Sudeste do Brasil (Barbosa et al. 2014). Na Serra do Cipó, foi observada em mata ciliar, florescendo e frutificando em novembro.

\section{Guettarda L.}

Arbustos a árvores; ramos cilíndricos a aplanados, em ramificação 2-3-furcada, com entrenós de extensões distintas. Estípulas inteiras, triangulares, decíduas. Folhas opostas, às vezes agrupadas na extremidade dos ramos. Inflorescências cimosas, escorpioides, axilares a subterminais, pedunculadas. Flores bissexuadas, actinomorfas, 5-7-meras; hipanto turbinado, com tubo bem desenvolvido, truncado a levemente denteado; corola com prefloração valvar, tubulosa até vinte vezes mais longa que o hipanto; ovário 2(-5) locular, pericarpo seco; pirenios oblongos.

18.1. Guettarda viburnoides Cham. \& Schltdl., Linnaea 4: 182. 1829.

Fig. 2. $\mathrm{H}$.

Arbustos ou arvoretas 2-5 m; ramos castanhoacinzentados, casca lenticelada, velutinos nas porções jovens, glabrescentes, entrenós 1,5-2(-7) cm compr., aplanados próximo ao ápice. Estípulas 3,5-4 x 2,5-3 $\mathrm{mm}$, velutinas, presentes apenas na gema apical. Folhas opostas, agrupadas na extremidade dos ramos, pecioladas; pecíolo $15-50 \mathrm{~mm}$ compr.; lâmina oval a oboval, base arredondada a truncada, margem plana, ápice arredondado a acuminado, (7-)9-16 cm compr., (4-)5-8 cm larg., cartácea a membranácea, fortemente discolor, secando castanho-claro a esverdeado com indumento velutino na face abaxial, e verde-oliváceo escuro na face adaxial; venação eucamptódroma, nervuras salientes na face abaxial, impressas na face adaxial, venação terciária paralela, evidente na face abaxial, domácias ausentes. Cimeiras escorpioides, 10-12-floras, longamente pedunculadas; pedúnculos 4-7 cm compr., velutinos; botões florais sésseis, obtusos; hipanto turbinado, 5-6 $\mathrm{mm}$ compr., seríceo, tubo truncado; corola hipocrateriforme, $30-45 \mathrm{~mm}$ compr., tubo externamente seríceo, acastanhado, fauce alva, lobos 5-7, patentes, espatulados, 5-6 mm compr.; estames adnatos à porção superior do tubo da corola; estigma incluso. Drupas globosas a subglobosas, levemente compressas, até $13 \mathrm{~mm}$ diâm., com restos do tubo do hipanto no ápice, pericarpo amarelo quando maduro; pirênios 1(-2) por fruto.

Material examinado: Itambé do Mato Dentro, Santana do Rio Preto (Cabeça de Boi), estrada das posses, a partir da casa de José Fernandes, rumo à mata do Cachoeirão, L.M. Borges \& M.F.Santos 292, 18.XII.2007, fl. (SPF); APA da Serra do Cipó, 1925'54,7"S, 4325'58,3"W, M.F. Santos \& H. Serafim 250, 13.III.2008, fr. (SPF). Santana de Pirapama, Serra do Cipó, acesso pela Faz. Inhame, $10 \mathrm{~km}$ a Sul da sede da Faz. Toucan Cipó, 1900'38"S, 4346'15"W, D.C. Zappi et al. 2058, 11.III.2009, fr. (K, RB, SPF); Fazenda Toucan Cipó, Limite Sul da fazenda, seguindo a cerca, D.C. Zappi, D.C. et al. 2465, 21.XI.2009, fl. (K, RB, SPF). Santana do Riacho, rodovia Belo Horizonte - Conceição do Mato Dentro, km 104, Morro do Calcáreo, R. Harley et al. CFCR 5888, 13.XI.1984, fl. (SPF); Cardeal Mota, Morro da Pedreira (2o grupo), J.R. Pirani et al. CFSC 13294, 22.VII.1993, estéril (SPF); idem, 1920'S, 4340'W, J.R. Pirani et al. 3686, 2.IV.1996, fr. (K, SPF).

Material adicional: Bahia: Jacobina, Cachoeira do Aníbal, $11^{\circ} 12^{\prime} 04^{\prime \prime} S, 40^{\circ} 29^{\prime} 45^{\prime \prime W}$, B. Stannard et al. PCD 2628 , 29.III.1996, fr. (ALCB, K, SPF). Goiás: $15 \mathrm{~km} \mathrm{~N}$ de Piranhas na estrada para Barra do Garças, W.R. Anderson 12435, 23.II.1982, fr. (MBM, SPF). Minas Gerais: Diamantina, estrada para Milho 
Verde, ca. 10 km SE de Diamantina, ca. 181' $14,8^{\prime \prime} \mathrm{S}$, 433'23,3"W, J.R. Pirani et al. 5894, fr. (CTES, R, SPF).

Amplamente distribuída no Brasil, esta espécie ocorre também na Bolívia (Govaerts 2013). Na Serra do Cipó, ocorre em cerrados e cerradões, e foi coletada em flor no mês de novembro e com frutos em março e abril.

\section{Hillia Jacq.}

Arbustos epifíticos ou terrestres, glabros; ramos espessos, carnosos, cilíndricos ou tetragonais. Estípulas intrapeciolares, lanceoladas, obovais a espatuladas, membranáceas, decíduas. Folhas opostas, decussadas, pecioladas. Inflorescências terminais, 1-3 floras, sésseis ou pedunculadas; flores vistosas, sésseis, solitárias ou agrupadas, 4-6-meras, bissexuadas, actinomorfas ou ligeiramente curvadas; hipanto truncado a 2-6-lobado, lobos, quando presentes, livres ou curtamente conatos, geralmente decíduos; corola com prefloração contorcida, hipocrateriforme ou infundibuliforme, tubo bem desenvolvido, lacínios patentes; estames 4-6, inclusos, inseridos abaixo da fauce da corola; ovário bicarpelar, bilocular, pluriovulado. Fruto capsular septicida, cilíndrico, levemente comprimido; sementes fusiformes, pequenas, comosas em uma das extremidades. 1760.

19.1. Hillia parasitica Jacq., Enum. syst. pl.: 18.

Fig. 2. I.

Arbusto prostrado, raramente escandente, 1-5 $\mathrm{m}$ alt.; ramos robustos, ligeiramente tetragonais, decumbentes, suculentos, rugosos quando secos. Estípulas oblongas, obtusas 8-30 mm compr. Folhas, pecioladas; pecíolo $0.8-1.5 \mathrm{~cm}$; lâmina elíptica, base atenuada a aguda, margem plana a levemente revoluta, ápice acuminado a acutiúsculo, 4-7(-10) cm compr., (1,5-)3-5 cm larg., cartácea a membranácea, glabra; venação eucamptódroma, nervuras secundárias pouco conspícuas na face abaxial, inconspícuas na face adaxial, domácias ausentes. Flores 6-meras, odoríferas, terminais, solitárias, sésseis; hipanto 4-5 mm compr., 2$4 \mathrm{~mm}$ larg., tubo do cálice curto, truncado; corola alva a rosada, tubulosa, levemente curvada, 9-13 cm compr., 3-5 mm larg., lobos patentes a reflexos, oblongos, 2-4 cm compr.; estigma verde. Cápsulas lenhosas, medianamente comprimidas, 4,5-9 cm compr., 5-9 mm larg.; sementes numerosas, 10-12 mm compr., 0,6-0,8 $\mathrm{mm}$ larg, comosas.

Material examinado: Jaboticatubas, Srrra do Cipó, rodovia Lagoa Santa - Conceição do Mato Dentro Diamantina, km 132, J. Semir \& M. Sazima CFSC 4770, 10 a 15.XII.1973, fr. (SP, UEC); idem, J. Semir \& M. Sazima CFSC 4940, 10. II.1974, fl. (SP, UEC). Santana do Riacho, Serra do
Cipó, A.M. Giulietti et al. CFSC 5528, 5.VII.1978, fl. (SP); idem, A. Rapini et al. 133, 24.V.1996, fl. (SP); estrada Belo Horizonte-Conceição do Mato Dentro, km 124, A.M. Giulietti et al. CFSC 12665, 29.VII.1991, fl., fr. (SPF); idem, A.M. Giulietti et al. CFSC 12668, 29.VII.1991, fl., fr. (SPF); idem, km 125, M.T.V.A. Campos et al. CFSC 12899, 7.III.1992, fl., fr. (SPF); idem, km 129, N.L. Menezes et al. CFSC 6396, 23.VII.1980, fr. (SP, SPF); idem, km 132, A.B. Joly \& J. Semir CFSC 3500, 2.XI.1972, fl., fr. (SP); idem, km 133, N.L. Menezes et al. CFSC 7104, 1.Ill.1981, fl. (F, SPF); idem, km 134, A. Furlan \& J.R. Pirani CFSC 6106, 23.V.1980, fr. (SP, $\mathrm{SPF})$; km 135, Parque Nacional da Serra do Cipó, J. Prado et al. CFSC 11541, 5.VII.1989, fl. (SPF); km 138, N.L. Menezes et al. CFSC 5833, 18.XII.1979, fl. (SP); Serra das Bandeirinhas, A.M. Giulietti et al. CFSC 12508, 27.VII.1991, fl. (SPF); Parque Nacional da Serra do Cipó, L.D. Meireles et al. 899, 28.II.2002, fr. (UEC); idem, F.A Vitta \& L.C Passos 357, VII.1996, fl. (UEC); estrada MG010, cerca de $400 \mathrm{~m}$ antes da bifurcação entre o Morro do Pilar e Conceição do Mato Dentro, M.T.V.A. Campos \& V.C. Souza CFSC 13536, 21.XI.1993, fl. (SP, SPF); Cardeal Mota, F. Feres et al. 98/30, 15.XII.1998, fl. (UEC).

Material adicional: Rio de Janeiro: Parque Nacional da Serra dos Órgãos, D.R. Hunt 6473, 3.VIII.1966, fl. (K).

Ocorre desde o México e Caribe até o Peru, sul da Bolívia e nordeste e sudeste e sul do Brasil, nos estados da Bahia, Minas Gerais, Rio de Janeiro, São Paulo e Santa Catarina (Barbosa et al. 2014). Na Serra do Cipó, é encontrada em campo rupestre, entre grandes rochas parcialmente na sombra, e nas proximidades de matas ciliares. Foi observada florescendo em de novembro a março e em julho, e frutificando em março, maio, julho e dezembro.

\section{Hindsia Benth.}

Arbustos ou subarbustos, glabros ou pubescentes. Estípulas interpeciolares triangulares, ápice glanduloso. Folhas opostas, curtamente pecioladas. Inflorescência em cimeiras ramificadas, multifloras, terminais a subterminais; flores bissexuadas, actinomorfas, 5-meras; lacínios curtamente deltoides; corola com prefloração valvar, hipocrateriforme, azul, alva ou rosada; estames 5, inclusos, inseridos na parte superior do tubo da corola; ovário bilocular, lóculos pluriovulados, estigma bífido. Fruto capsular, globoso, lenhoso; sementes discoides, aladas.

20.1. Hindsia Iongiflora Benth., Lindl. Bot. Reg. tab. 40. 1844.

Fig. 2. J-K.

Arbusto 3-4 m; ramos castanho claros, casca estriada a fissurada, suberificada nas porções mais velhas, entrenós 1-2 cm compr. Estípulas estreitamente triangulares, 3-4 x 1,5-2,5 mm, com margem irregularmente serreada. Folhas pecioladas; 
pecíolo 5-8 $\mathrm{mm}$ compr.; lâmina estreitamente lanceolada, base decorrente, margem revoluta, ápice agudo a acuminado, 4-6 cm compr., 0,6-1 cm larg., cartácea, discolor, secando verde-olivácea a enegrecida, esparsamente estrigosa em ambas as faces, com tricomas concentrados sobre as nervuras; venação broquidódroma, nervuras salientes na face abaxial, impressas na face adaxial, retículo evidente na face abaxial, domácias ausentes. Inflorescências terminais, compactas, com 3 pedúnculos aplanados, de até $1 \mathrm{~cm}$; botões florais pedicelados, agudos, com constrição subapical; tubo da corola externamente seríceo, acinzentado; hipanto turbinado, 2-3 mm compr., seríceo, tubo ausente, lacínios subulados, 5-9 $\mathrm{mm}$ compr.; corola 45-65 mm compr.; alva a azulada, hipocrateriforme, lobos fortemente reflexos, ovais, 10 $12 \mathrm{~mm}$ compr.; estames inclusos, estigma bífido, exserto. Cápsulas loculicidas e septicidas, globosas a ovoides, até $10 \mathrm{~mm}$ compr.; pericarpo castanho, rígido; sementes não observadas.

Material examinado: Jaboticatubas, Serra do Cipó, nas proximidades da divisa do Parque rumo a Conceição do Mato Dentro, H.F. Leitão Filho 27306, 7.XII.1992, fl. (UEC). Santana do Riacho, Cachoeira do Rio Capivara, J.R. Pirani et al. CFSC 6851, 14.XII.1980 fl., fr. (R, SPF). 'Serra da Lapa', Riedel 914, XI.1824, fl. (K).

Material adicional: Minas Gerais: Santa Bárbara, Serra do Caraça, H.F. Leitão Filho 9601, 12.XII.1978, fl. (UEC); idem, caminho a Cascatona, J.R. Pirani et al. 365, 18.XII.1982, fl., fr. (SPF). Rio de Janeiro: Parque Nacional da Serra dos Órgãos, D.R. Hunt 6473, 3.VIII.1966, fl. (K).

De ocorrência esporádica, Hindsia longiflora é encontrada em regiões de altitude nos estados da Bahia e Minas Gerais ( $H$. longiflora subsp. longiflora), e no Rio de Janeiro $(H$. longiflora subsp. colorata Di Maio) (Di Maio 1996). Foi coletada com flor em novembro e dezembro e com frutos velhos, no mês de dezembro na Serra do Cipó. A espécie não foi recoletada na região desde 1992.

\section{Manettia L.}

Arbustos ou ervas escandentes; ramos delgados, volúveis. Estípulas interpeciolares triangulares, conatas, geralmente pubescentes. Folhas opostas, pecioladas ou sésseis, glabras ou tomentosas. Inflorescências cimosas (dicásios), geralmente terminais, paucifloras; flores bissexuadas, actinomorfas, 4(5)-meras, heterostílicas; lacínios 4(-6 ou 8), obovoides ou campanulados, persistentes; corola com prefloração valvar, infundibuliforme a estreitamente tubulosa, rubra, amarela, vermelhoamarelada ou alva, glabra ou pubescente; estames usualmente 4, inseridos na fauce da corola; ovário bilocular, lóculos pluriovulados; estigma bipartido. Fruto capsular septicida, coriáceo; sementes pequenas, discoides, aladas.
21.1. Manettia cordifolia Mart., Denkschr. Königl. Akad. Wiss. München 9: 95; tab. 7. 1824.

Fig. 5. A.

Ervas escandentes; ramos delgados, tomentosos, cilíndricos, volúveis. Estípulas pequenas, $2-3 \times 2-3 \mathrm{~mm}$, tomentosas. Folhas pecioladas, pecíolo 2-7 mm; lâmina lanceolada a oval (geralmente cordiforme quando subtendendo as inflorescências), base truncada a cordada, margem plana, ciliada, ápice agudo, (3-)5-8 cm compr., 1,5-3 cm larg., membranácea a cartácea, glabra ou serícea; venação broquidódroma, nervuras secundárias 4-5 pares, pouco evidentes a salientes na face abaxial, pouco evidentes a impressas na face adaxial. Inflorescências subterminais a axilares, 1-3-floras; flores 4-meras, pediceladas; lacínios triangulares a lanceolados, 4-6 $\mathrm{mm}$ compr., 2-4 mm larg.; corola vermelha, tubulosa, 4,5-6 cm compr., 0,7-1 cm larg., glabra; estames 4, subsésseis, exsertos, anteras enegrecidas; estigma curtamente bipartido, vináceo a nigrescente. Cápsula subglobosa a ovoide, ca. $1,5 \mathrm{~cm}$ compr., glabra; sementes ca. $4 \mathrm{~mm}$ compr.

Material examinado: Jaboticatubas, Serra do Cipó, rodovia Lagoa Santa - Conceição do Mato Dentro Diamantina, estrada da Usina, a $10 \mathrm{~km}$ da Pensão Chapéu de Sol, A.B. Joly et al. CFSC 1671, 16.IV.1972, fl. (SP). Santana de Pirapama, Faz. Inhame, 1855'S, 4354'W, I. Cordeiro et al. CFSC 8223, 24.III.1982, fl. (ÍSPF); Distr. de São José da Cachoeira (Inhame), estrada que liga a Faz. Toucan Cipó ao Rio Cipó, D.C. Zappi 2287, 7.XI.2009, fl. (K, RB, SPF). Santana do Riacho, APA do Morro da Pedreira, perto de Cardeal Mota, J.R. Pirani \& C. Kameyama CFSC 12957, 25.IV.1992, fl. (SPF); idem, 1918'45"S, 433'ㄷㄴ"W, J.R. Pirani et al. 5002, 5.III.2002, fl., fr. (SPF); Rodovia Belo Horizonte - Conceição do Mato Dentro, km 110, fr., A. FreireFierro \& G.L. Esteves CFSC 11837, 27.VI.1990, fl., (QCA, SPF); idem, km 117, I. Cordeiro et al. CFSC 7067, 1.III.1981 fl., fr. (PEL, SPF); Ribeirão Indequicé, próximo a Estrada da Usina, C. Kameyama et al. CFSC 9468, 14.XII.1985, fl. (SPF); Serra da Bandeirinha, A. Rapini et al. 429, 23.X.1997, fl. (SPF); 1923'S, 4335'W, V.C. Souza et al. 25276 , 6.VII.2001, fl. (ESA, K).

Manettia cordifolia é encontrada no Peru, Bolívia, Paraguai, Uruguai, Argentina e Brasil (Govaerts 2013). Na Serra do Cipó, ocorre no interior de matas ciliares e na mata decidual do afloramento de calcário em Cardeal Mota, e também em vegetação perturbada. Foi coletada em flor em março, abril, junho, julho, outubro, novembro e dezembro, e em fruto de março a junho.

\section{Margaritopsis C.Wright}

Arvoretas, arbustos ou subarbustos; ramos cilíndricos, geralmente costados, glabros ou raramente pubescentes. Estípulas persistentes ou caducas, frequentemente formando uma bainha tubular inteira, 
raramente lobada. Folhas opostas, pecioladas. Inflorescência terminal séssil, em dicásios ou panículas multifloras. Flores bissexuadas, actinomorfas, 5meras, distílicas; hipanto com tubo desenvolvido, denteado; corola com prefloração valvar, sem gibosidade; ovário 2-locular, lóculos uniovulados. Drupas elipsoides a subglobosas, carnosas, vermelhas quando maduras; pirênios 2, unisseminados, lisos ou costados.

\subsection{Margaritopsis cephalantha (Müll.Arg.)} C.M.Taylor, Syst. Geogr. PI. 75: 171. 2005.

Fig. 6. E.

Arbustos ou arvoretas, 1,2-3 m alt.; ramos cilíndricos, levemente aplanados, com uma estria longitudinal em cada lado do ramo, castanho-claros, glabros. Estípulas inteiras, agudas a múticas, 1-2 × 3-4 $\mathrm{mm}$, decídua deixando uma cicatriz truncada nos pares de folhas inferiores. Folhas pecioldas; pecíolo 0,5-0,8(-1) cm compr.; lâmina lanceolada a elíptica, (46-9(-12) cm compr., 2-3,5(-5) cm larg., base cuneada a decorrente, margem plana a levemente revoluta, ápice agudo a acuminado, raramente obtuso, membranácea a subcartácea, discolor, secando verdeolivácea na face adaxial, verde-clara acinzentada na face abaxial; venação broquidódroma, nervuras secundárias (6-)7-11 pares, subpatentes, distanciadas, salientes e amareladas, com retículo visível na face abaxial, levemente salientes na face adaxial, domácias ausentes. Inflorescências glomerulares, sésseis a subsésseis; pedúnculo (na infrutescência) 1-3 mm compr., brácteas ovais, paleáceas, 2-3 mm compr.; flores 5-meras, sésseis; hipanto 1,5-2 x 1,2 mm, tubo do cálice expandido, apicalmente denticulado; corola alva, $4 \mathrm{~mm}$ compr., 2-2,5 mm larg., glabra externamente, pilosa internamente abaixo da inserção dos estames, lobos patentes, corniculados; estames 5 , exsertos nas flores brevistilas; estigma bífido, incluso nas flores brevistilas, glabro. Drupas globosas, costadas quando secas, vermelhas quando maduras, 4,5-5,5 mm compr., 3,5-4,5 mm larg.

Material examinado: Itambé do Mato Dentro, Distrito de Santana do Rio Preto. APA do Parque Nacional da Serra do Cipó, 1923'53,9"S, 4324'9,2"W, M.F. Santos \& E.G. Martins 150, 24.VIII.2007, fl., fr. (SPF); 1923'46,9"S, 4324'7,4"W, M.F. Santos \& H. Serafim 330, 16.III.2008, fl., fr. (SPF).

Material adicional: Minas Gerais: Araguari, Bosque John Kennedy, G.M. Araújo et al. 992, 2.l.1993, fl., fr. (HUFU, K).

Ocorrendo em todos os estados do Sudeste do Brasil, esta espécie estende-se até a Bahia, Alagoas, Goiás e Amazônia (Amazonas, Acre e Rondônia), e ocorre também na Bolívia, no Peru e na Colômbia (Govaerts 2013). Na Serra do Cipó, cresce na região mais úmida e foi coletada em mata nebular e capão de mata, com flores e frutos em março e agosto.

\section{Molopanthera Turcz.}

Árvores ou arbustos; ramos cilíndricos, glabros ou tomentosos. Estípulas interpeciolares triangulares, decíduas e pilosas. Folhas opostas, pecioladas. Inflorescência multiflora, em panículas terminais ou subterminais; flores bissexuadas, zigomorfas, 5meras, alvas, botões florais curvos; lacínios triangulares pilosos; corola com prefloração imbricada, rotácea, glabra ou levemente pilosa na parte inferior do tubo; estames 5, dimórficos, exsertos, inseridos na base do tubo da corola; ovário bilocular, lóculos pluriovulados; estigma bífido. Fruto capsular loculicida, globoso, piloso; sementes numerosas, oblongoelípticas, aladas.

23.1. Molopanthera paniculata Turcz., Bull. Soc. Imp. Nat. Moscou 21: 581. 1848.

Fig. 3. E-F.

Árvore $5 \mathrm{~m}$ alt.; casca fendilhada longitudinalmente; ramos cilíndricos, pubescentes a seríceos, glabrescentes quando velhos. Estípulas curtamente aristadas, tomentosas a glabrescentes, 2 x 3-5 mm. Folhas pecioladas; pecíolo 8-10 mm compr.; lâmina oval, base arredondada a obtusa, margem plana, ápice acuminado, 5-8(-10) cm compr., 2,5-4,5 cm larg., membranácea, glabra a esparsamente pilosa em ambas as faces, tomentosa nas nervuras da face abaxial; venação broquidódroma, nervuras salientes na face abaxial, impressas na face adaxial, domácias ausentes. Panículas multifloras, terminais e subterminais, até $15 \mathrm{~cm}$ compr.; hipanto 1-2 mm compr., ca. $1 \mathrm{~mm}$ larg., pubescente; corola ca. $3 \mathrm{~mm}$ compr., ca. $2 \mathrm{~mm}$ larg., creme, lobos fortemente reflexos; estames dimórficos, 3 com filetes espessos, pubescentes e curtos, anteras sem apêndice, 2 com filetes delgados, glabros, anteras com apêndice basal. Cápsulas globosas a biglobosas, verde-claras, 2,5-3 $\mathrm{mm}$ compr., 4-5 mm larg.; sementes orbiculares, delgadas, 1-1,2 mm diâm.

Material examinado: Santana do Riacho, Serra do Cipó, APA do Morro da Pedreira, perto de Cardeal Mota, J.R. Pirani \& C. Kameyama CFSC 12952, 25.IV.1992, fr. (NY, RB, SPF). Sem município, Serra do Cipó, E.P. Heringer 5280, s.d. $(\mathrm{SP})$.

Material adicional: Minas Gerais: Grão-Mogol, vale do Riacho Ribeirão, $900 \mathrm{~m}$ alt., J.R. Pirani \& R. Mello-Silva CFCR 10870, 25.V.1987, fl. (SPF); Lagoa Santa, Warming s.n., s.d., fl. (K); São Gonçalo do Rio Preto, Parque Estadual do Rio Preto, E.B. Foresto et al. 285, 25.IV.2006, fr. (K, NY, SPF); Serro, $3 \mathrm{~km}$ from town, L.O. Williams et al. 6861, 12.V.1945, fl. (K).

Essa espécie ocorre na Bahia, Minas Gerais e Rio de Janeiro (Barbosa et al. 2014). Suas flores apresentam uma antese peculiar, semelhante àquela 
observada em espécies de Posoqueria. Os estames dimórficos, que se encontram unidos por meio das anteras ao interior do botão, movimentam-se de maneira brusca durante a antese, separando-se inicialmente em dois grupos e, posteriormente tornando-se reflexos. Na Serra do Cipó é rara, com apenas dois registros, um deles no afloramento de calcário na base da serra, em fruto no mês de abril.

\section{Oldenlandia L.}

Ervas simples ou ramificadas, raramente subarbustos; ramos delicados, cilíndricos, geralmente rasteiros ou decumbentes. Estípulas agudas, acuminadas ou aristadas. Folhas opostas, decussadas, geralmente estreitas e sésseis. Inflorescências cimosas axilares ou terminais, paucifloras ou flores solitárias. Flores bissexuadas, actinomorfas, 4-meras, geralmente distílicas; hipanto lobado, tubo ausente; corola com prefloração valvar, rotácea ou infundibuliforme, alva ou rosada; estames inseridos na porção distal do tubo, exsertos; ovário 2locular, lóculos pluriovulados; estilete filiforme, estigma bífido. Cápsulas subglobosas a turbinadas, 2 loculares, deiscência loculicida a partir do ápice; sementes numerosas, trígonas a cônicas, não aladas.

24.1. Oldenlandia salzmannii (DC.) Benth. \& Hook. f. Gen. pl. 2(1): 58. 1873.

Fig. 5. D-E.

Ervas simples, decumbentes, $5-10 \mathrm{~cm}$ alt.; ramos delgados, glabros, avermelhados. Estípulas triangulares, ca. $1 \mathrm{~mm}$ compr. Folhas sésseis; lâmina elíptica, oboval ou lanceolada, base arredondada,margem plana, ápice arredondado a agudo, 2-5 mm compr., 1-3 mm larg., cartácea, glabra; venação eucamptódroma, nervuras secundárias pouco conspícuas a inconspícuas. Cimeiras reduzidas, 1-3floras; flores pediceladas; hipanto 2-2,5 mm compr., ca. $2 \mathrm{~mm}$ larg., cupuliforme, tubo ausente, lobos lanceolados a triangulares; corola rósea, lilás a azulada, 3-4 mm compr., 2-3 mm larg; estigma bífido. Cápsula obovoide, verde-avermelhada, multisseminada.
Material examinado: Jaboticatubas, Serra do Cipó, margem da estrada no caminho para represa da Usina, A.M. Giulietti \& N. Menezes CFSC 4044, 7.II.1973, fl. (SP); rodovia Lagoa Santa - Conceição do Mato Dentro - Diamantina, km 128, I. Sazima CFSC 4737, 31.X.1973, fl. (SP, UEC); idem, km 131, J. Semir \& M. Sazima CFSC 5061, 6.VII.1974, fl., fr. (SP). Santana do Riacho, L.S. Kinoshita \& K. Matsumoto 00/532, 22.XI.2000, fl. (UEC); Lapinha, Pico do Breu, 1910'S, 43ㄴ2'W, A. Tozzi \& L. Kinoshita 602, 23.XI.2000, fl. (UEC); lagoa da Lapinha, D.C. Zappi 847, 25.VIII.2007, fl., fr. (K, SPF); entre a sede do IBAMA e o Canyon das Bandeirinhas, 19-23'S, 433' W, V.C. Souza et al. 25270, 6.VII.2001, fl. (ESA); Serra das Bandeirinhas, A. Rapini \& R.C. Forzza 428, fl. (SPF).

Material adicional: Bahia: Água Quente, Pico das Almas, 1330'S, 4159'W, R.M. Harley \& N. Hind 27268, 16.XII.1988, fl., fr. (K, SPF); $12 \mathrm{~km} \mathrm{~N}$ of Alcobaça towards Prado, R.M. Harley 18002, 16.I.1977, fl., fr. (CEPEC, K).

Ondenlandia salzmanii tem distribuição ampla na região meridional da América do Sul, ocorrendo na Argentina, Paraguai e Uruguai. No Brasil, distribui-se no Sul e Sudeste e também na Bahia (Zappi \& Stannard 1995). Na Serra do Cipó, foi coletada em proximidades de lagoas e cursos d'água, com flores e frutos nos meses de julho e novembro.

\section{Palicourea Aubl.}

Arbustos ou subarbustos, raramente arvoretas; ramos tetragonais ou cilíndricos, glabros ou pubescentes. Estípulas interpeciolares bipartidas ou bífidas, decíduas ou persistentes, conatas ou livres. Folhas opostas, raramente ternadas ou quaternadas, glabras ou pubescentes. Inflorescências terminais, de tipos variados, geralmente com ramos de colorido vistoso; flores bissexuadas, zigomorfas, levemente alargadas na base, 5-meras; lacínios curtos, denteados; corola com prefloração valvar, hipocrateriforme, frequentemente amarela, alaranjada, rósea, vermelha, roxa a azul, glabra ou pubescente, tubo com base gibosa ou tubo curvado, internamente dotado de um anel de tricomas, lobos curtos; estames 5 , inseridos geralmente na porção mediana do tubo da corola; ovário 2(-5)-locular, lóculos uniovulados. Fruto drupa, com 2(-5) pirênios; sementes sulcadas.

Chave para as espécies

1. Ramos basais suberificados; folhas coriáceas, ápice arredondado a retuso, raramente agudo 25.2. P. rigida

1'. Ramos sempre delgados; folhas membranáceas a cartáceas, com ápice longamente acuminado.

2. Folhas opostas; corimbos irregulares com a maioria das flores no mesmo plano

2 '. Folhas verticiladas; inflorescência piramidal 
25.1. Palicourea marcgravii A.St.-Hil., Hist. PI. Remarq. Brésil: 231. 1825.

Fig. 6. F-G.

$\begin{array}{ll}\text { Arbustos ou subarbustos } & 1-1,5 \mathrm{~m} \text { alt.; ramos } \\ \text { cilíndricos, esparsamente pubérulos, não }\end{array}$ suberificados. Estípulas bipartidas, livres, persistentes, 1-1,8 x 2-4 mm, apêndices triangulares, pilosos. Folhas opostas, pecioladas; pecíolo $0,7-1,2 \mathrm{~cm}$ compr.; lâmina elíptica, oval ou oboval, base aguda a levemente decorrente, margem plana, ápice longamente acuminado, 6-15 cm compr., 3-6 cm larg., membranácea, diminutamente pubérula, ocasionalmente glabrescente; venação broquidódroma, nervuras secundárias 8-12 pares, salientes em ambas as faces, nervuras intersecundárias ausentes, retículo pouco conspícuo. Corimbos multifloros ovoides, aplanados no ápice, longo-pedunculadas, amarelas, alaranjadas ou avermelhadas; flores pediceladas; hipanto 1-1,3 mm compr., c. $1 \mathrm{~mm}$ larg., estreitamente turbinado, lacínios curtamente triangulares; corola amarela ou alaranjada com lobos lilases, $18-20 \mathrm{~mm}$ compr., 4-5 mm larg., densamente curto-vilosa; estigma bífido. Infrutescência vermelho-escura a vinácea com ápice amarelado; drupa globosa, comprimida, sulcada, glabra a pubérula, verde passando a purpúrea, $4-5 \mathrm{~mm}$ compr., 6-7 mm larg.; sementes 2, plano-convexas, levemente costadas dorsalmente.

Material examinado: Santana de Pirapama, Serra do Cipó, acesso pela Faz. Inhame, Estrada entre Capela de São José e Santana do Riacho, Faz. Toucan Cipó, 1859'26"S, 4346'38"W, D.C. Zappi et al. 1833, 7.III.2009, fr. (K, RB, SPF). Santana do Riacho, Estrada da Usina, M.C. Henrique et al. CFSC 6886, 9.I.1981, fl., fr. (SP); RPPN Brumas do Espinhaço e Ermo do Gerais, C.A. Ferreira Junior et al. 792, 28.XI.2012, fl. (BHZB, SPF).

Material adicional: Minas Gerais: Grão-Mogol, estrada para Rio Ventania, 1632'S, 4249'W, P.T. Sano et al. CFCR 12701, 13.XII.1989, fl. (SPF); São Gonçalo do Rio Preto, Parque Estadual do Rio Preto, Capão Azul, E.B. Foresto et al. 140, 1.XI.2005, fl. (SPF); idem, E.B. Foresto et al. 345, 25.VI.2005, fr. (BHCB, SPF). São Paulo: Iporanga, V.C. Souza 5881, IV.1994, fl. (ESA, MO, UEC).

Endêmica do Brasil, Palicourrea marcgravii é amplamente distribuída nas regiões Sul, Sudeste e Centro-oeste (Barbosa et al. 2014). Foi coletada apenas duas vezes na Serra do Cipó, crescendo em mata ciliar, florescendo e frutificando em janeiro e março.

25.2. Palicourea rigida Kunth. in Humb., Bompl. \& Kunth, Nov. gen. sp. 3: 370. 1819.

Fig. 6. $\mathrm{H}$.

Arbustos ou subarbustos $0,2-1,5 \mathrm{~m}$ alt.; ramos cilíndricos, raramente tetragonais, esparsamente pubérulos, ramos basais fortemente suberificados.
Estípulas bipartidas, conatas, persistentes, 5-15 x 5-15 $\mathrm{mm}$, apêndices triangulares, rígidos, glabros. Folhas opostas a falsamente verticiladas, pecioladas; pecíolo 0,1-6 cm compr.; lâmina elíptica a oboval, base aguda, margem espessada, ápice arredondado a retuso, raramente agudo $6,5-14 \mathrm{~cm}$ compr., $4-8,5(-10) \mathrm{cm}$ larg., coriácea, esparsamente pubérula a glabrescente; venação broquidódroma, nervuras secundárias 9-16 pares, salientes em ambas as faces, amareladas em plantas vivas, retículo proeminentes na face abaxial. Panículas multifloras ovoides, compactas, longo-pedunculadas; flores pediceladas; hipanto 1-1,5 $\mathrm{mm}$ compr., ca. $1 \mathrm{~mm}$ larg., estreitamente turbinado, lacínios curtamente denteados; corola amarelo-alaranjada, (11,5-)14-18,5 $\mathrm{mm}$ compr., (3-)3,5-4,5 mm larg., pubérula; estigma bífido. Infrutescência amarela a avermelhada; drupa globosa, medianamente comprimida, costada, pubérula, vinácea, ca. $5 \mathrm{~mm}$ compr., ca. $5 \mathrm{~mm}$ larg.; sementes 2, plano-convexas, levemente costadas dorsalmente.

Material examinado: Congonhas do Norte, trilha em direção ao Retiro do Barbado, após a Fazenda do Sr. José Correia, $18^{\circ} 51$ 'S, 4345'W, A. Furlan et al. CFSC 8363, 21.IV.1982, fl. (SPF). Jaboticatubas, 19-20'978'S, 433'847"W, L.S. Kinoshita \& A.O. Simões 00/149, 21.XI.2000, fl. (UEC); nas proximidades da divisa do Parque rumo a Conceição do Mato Dentro, H.F. Leitão Filho et al. 27346, 7.XII.1992, fl. (UEC); estrada para a sede do IBAMA, F.A Vitta 387, 17.XII.1996, fl. (UEC); rodovia Lagoa Santa Conceição do Mato Dentro - Diamantina, km 118, A.B. Joly et al. CFSC 918, 4.III.1972, fl. (SP, UEC); idem, km 118-119, 1918-19' 4345', G. Eiten \& L.T. Einten 6897, 25.XI.1965, fl. (SP); idem, km 120, A.B. Joly \& J. Semir CFSC 3551, 3.XI.1972, fl. (SP); idem, km 124, N.L. Menezes 4575, 19.X.1973, fl. (SP); idem, km 128, A.B. Joly et al. CFSC 1644 , 15.IV.1972, fl. (SP); Estrada da Usina, a $10 \mathrm{~km}$ da Pensão Chapéu de Sol, A.B. Joly et al. CFSC 1721, 16.IV.1972, fl. (SP); km 2 estrada da Usina, A.B. Joly et al. CFSC 1160, 5.III.1972, fl. (SP). Santana de Pirapama, Serra do Cipó, Faz. Inhame, 1855'S, 4354"W, I. Cordeiro et al. CFSC 8159, 23.III.1982, fl., fr. (SPF); Vilarejo Inhame, Fazenda Toucan Cipó, L.M. Borges et al. 206, 16.XI.2007, fl. (SPF); estrada para a captação, D.C. Zappi et al. 708, 15.II.2007, fl. (ESA, HUEFS, K, SPF). Santana do Riacho, Serra do Cipó, J.Y. Tamashiro 25655, 7.XI.1991, fl. (UEC); estrada Belo Horizonte-Conceição do Mato Dentro, km 106, G.M. Faria \& M. Mazucato 68, IV.1990, fl. (SPF); idem, km 108, 1917'14"S, 4335'16"W, M.A. Pena et al. 52, 12.XII.2006, fl. (SPF); idem, km 114, P.E. Gibbs \& J. Semir CFSC 5369, 9.XII.1975, fl. (SP), idem, km 117, N. Chukr \& S.A.P. Godoy CFSC 9954, 16.l.1987, fl. (SPF); idem, km 120, 1918'S, 433'W, G. Eiten \& L. Eiten 6833, 24.XI.1965, fl. (K, SP, UB); Serra da Farofa, A. Rapini et al. 405, 21.X.1997, fl (SPF); Parque Nacional da Serra do Cipó, L.S. Kinoshita \& J.Y Costa 00/209, 22.XI.2000, fl. (UEC); caminho da base do IBAMA do Rio Cipó para o Capão dos Palmitos, J.R. Pirani et al. CFSC 12025, 25.III.1991, fl. (SPF); Estrada da Usina, l. Cordeiro et al. CFSC 6788, 10.XI.1980, fl. (SP); RPPN Brumas do Espinhaço e Ermo do Gerais, F.M. Fernandes et al. 359, 29.XI.2012, fl. (BHZB, SPF). 
Material adicional: Bahia: Rio de Contas, Pico das Almas, 1333'S, 4157'W, R.M. Harley 19544, fr. (CEPEC, K).

Palicourea rigida ocorre em savanas e cerrados da América tropical. Apresenta variação no indumento das folhas, inflorescências e frutos e também no formato dos lacínios e da corola (Steyermark 1972), mas é de fácil reconhecimento por meio dos ramos suberificados. Na Serra do Cipó, ocorre associada a cerrados e cerrados de altitude, florescendo em de outubro a abril, e frutificando em março-abril.

25.3. Palicourea tetraphylla Cham. \& Schltdl., Linnaea 4: 17. 1829.

Fig. 6. I-J.

Árvores ou arvoretas, 2-6 m alt.; ramos jovens quadrangulares, fistulosos, glabros, não suberificados. Estípulas bipartidas, conatas, persistentes, 3-5 x 4-6 $\mathrm{mm}$. Folhas (3-)4-5-verticiladas, pecioladas; pecíolo 1 $1,8 \mathrm{~cm}$ compr.; lâmina oval a estreitamente lanceolada, base aguda a decorrente, margem plana, ápice longamente acuminado, (7-)10-20 cm compr., (2-)3-8 cm larg., cartácea, tomentosa na face abaxial, glabra a esparsamente curto-pilosa na face adaxial; venação broquidódroma, nervuras secundárias 10-20 pares, salientes na face abaxial, nervuras intersecundárias e retículo conspícuos na face abaxial. Panículas multifloras piramidais, longo-pedunculadas, vermelhas; hipanto 1-1,5 mm compr., ca. $1 \mathrm{~mm}$ larg., tubo ausente, lobos curtos, patentes; corola amarela (alva com tricomas castanhos em Campos et al. CFSC 13170), 10-12 mm compr., ca. $3 \mathrm{~mm}$ larg., lobos patentes; estigma bífido. Infrutescência vinácea, drupas bi-globosas, costadas, verde-claras, 3-4 mm compr., 5,5-6 mm larg.; sementes não observadas.

Material examinado: Congonhas do Norte, Serra do Cipó, estrada para Costa Senna, 18ㄴ5'04"S, 43ํ40'43"W,
J.R. Pirani et al. 4089, 1.III.1998, fr. (SPF); Serra Talhada (setor nordeste da Serra do Cipó), ca. 6 km SW da estrada Congonhas do Norte - Gouveia, entrada a $3,7 \mathrm{~km} \mathrm{NW}$ de Congonhas do Norte, estrada pelo alto da serra em local denominado localmente como Retiro dos Pereiras, 1848'48"S, 4344'21"W, L.M. Borges et al. 351, 4.II.2009, fl. (SPF); idem, $9 \mathrm{~km}$ S de Congonhas do Norte na estrada para Conceição do Mato Dentro, entrada para Extrema, seguindo $7 \mathrm{~km}$, estrada para Lapinha, 185' 19,2"S, 4341'01,3"W, M.F. Calió et al. 198, 20.I.2007, fl. (SPF); alto da Serra do João Camilo, 1848'39"S, 4337'09"W, R. Riina et al. 1325, 19.I.2004, fl. (K, SPF). Santana de Pirapama, Serra do Cipó, Capela de São José, Trilha da Senhorinha, caminho para Congonhas do Norte, 185' 35,6 "S, 4344'44,8"W, D.C. Zappi et al. 2505, 24.XI.2009, fl. (K, RB, SPF). Santana do Riacho, Serra do Cipó, estrada Belo Horizonte-Conceição do Mato Dentro, $1,8 \mathrm{~km}$ após a bifurcação na estrada para Morro do Pilar, M.T.V.A. Campos et al. CFSC 13170, 20.VII.1993, fl. (SPF).

Palicourea tetraphylla ocorre na Mata Atlântica e matas ciliares associadas aos cerrados nos estados de Minas Gerais, São Paulo e Espírito Santo (Barbosa et al. 2014). Na Serra do Cipó, ocorre em matas ciliares e foi coletada com flores em julho e janeiro, frutificando em março.

\section{Perama Aubl.}

Ervas eretas, delicadas, anuais ou perenes, simples ou em touceiras, às vezes plantas rosuladas, sempre de pequeno porte. Estípulas pequenas a inconspícuas, e então cobertas de tricomas setosos. Folhas opostas, 3-verticiladas ou em roseta na base do pedúnculo, sésseis. Inflorescência multiflora, fasciculada, cimosa, simples ou ramificada; flores bissexuadas, actinomorfas, 4-meras; hipanto bilobado; corola com prefloração valvar, infundibuliforme, amarela, rosada, lilás ou alva, 4-lobada; estames 4, anteras de ápice acuminado; ovário trilocular, lóculos uniovulados; estigmas 2-3. Fruto capsular, deiscência circular; sementes prismáticas.

Chave para as espécies

1. Entrenós visíveis, $1-2,5 \mathrm{~cm}$ compr.; inflorescências tirsoides, terminais 26.2. P. parviflora

1 . Entrenós ocultos pelas folhas, geralmente com menos que $1 \mathrm{~cm}$ compr.; inflorescências compactas, sésseis, axilares ou pseudoaxilares.

2. Ervas com caules simples ou pouco ramificados, cobertas por tricomas seríceos adpressos, prateados quando secos; flores lilases

2 '. Ervas muito ramificadas, cobertas por tricomas hirsutos, semi-eretos, amarelados a ferrugíneos quando secos; flores alvas

26.1. Perama holosericea (Naudin) Wurdack \& Steyerm., Bradea 1(16): 151. 1972.

Fig. 8. A-B.

Erva perene, ereta, $10-20 \mathrm{~cm}$ alt., crescendo em pequenas touceiras de 1-4 ramos delgados, hirsutos, 1-2-ramificados, encobertos pelas folhas adpressas; entrenós com menos de $1 \mathrm{~cm}$ compr. Estípulas inconspícuas, hirsutas. Folhas sésseis, opostas, decussadas, suberetas, cobrindo os ramos; lâmina oboval a oval, base amplexicaule, margem revoluta, ápice agudo a acuminado, 4-6 mm compr., 3$4 \mathrm{~mm}$ larg., cartácea, verde-clara quando seca, densamente coberta por tricomas adpressos seríceos, 
prateados; nervuras inconspícuas. Inflorescências axilares, paucifloras; flores sésseis; hipanto zigomorfo, 2-3 mm compr., 1-1,5 mm larg., lacínios 2, externamente seríceos; corola lilás, 7-8 mm compr., ca. $2 \mathrm{~mm}$ larg., externamente serícea; lobos suberetos, triangulares, $2 \mathrm{~mm}$ compr., anteras subsésseis, inclusas; estilete exserto. Cápsula $5 \mathrm{~mm}$ compr.; sementes obovais a prismáticas, castanhas, 1 $x$ 0,8-0,9 mm.

Material examinado: Congonhas do Norte, Serra da Mangabeira, margem direita do Rio Preto, A. Furlan et al. CFSC 8436, 23.IV.1982, fl., fr. (SPF); Serra Talhada (setor nordeste da Serra do Cipó), $9 \mathrm{~km} \mathrm{~S}$ de Congonhas do Norte na estrada de Conceição do mato Dentro, entrada para Extrema seguindo ca. $11 \mathrm{~km}$, estrada para Lapinha, 1856'23.4"S, 4340'55.7"W, J.R. Pirani et al. 5717, 3.II.2009, fl. (SPF). Santana de Pirapama, Faz. Inhame, 1855'S, 4354'W, I. Cordeiro et al. CFSC 8131, 23.III.1982, fl. (SPF); subida da Senhorinha, 1900'00"S, 4345'47"W, D.C. Zappi et al. 821, 19.II.2007, fl. (ESA, K, SPF); acesso pela Faz. Inhame, Trilha da Senhorinha, topo da serra, 18056'14"S, 4344'36"W, D.C. Zappi \& N.P. Taylor 2251, 27.VII.2009, fl. (K, RB, SPF); Capela de São José, Trilha da Senhorinha, caminho para Congonhas do Norte, D.C. Zappi et al. 2613, 25.XI.2009, fl., fr.(K, RB, SPF).

Material adicional: Minas Gerais: Serra do Frio [Mun. Serro], Vauthier 501, 1833, fl. (G); Diamantina, estrada para Conselheiro Mata, 3-6 km da estrada Diamantina-Gouveia, 14.III.1999, fl., V.C. Souza \& J.P. Souza 22186 (CTES, ESA).

Perama holosericea ocorre em Minas Gerais, sendo endêmica da região Noroeste da Serra do Cipó até Diamantina (Steyermark \& Kirkbride 1977). É encontrada em campo rupestre entre rochas, florescendo e frutificando entre janeiro e agosto. A distribuição desta espécie possui uma zona de contato com P. sparsiflora (ver abaixo) no município de Congonhas do Norte, onde ambas ocorrem, porém mantendo-se bem distintas.

26.2. Perama parviflora (Standl.) J.H. Kirkbr. \& Steyerm., Brittonia 29: 195. 1977.

Perama irwiniana Kirkbr. \& Steyerm., Brittonia 29: 195. 1977, syn. nov.

Fig. 8. D-F.

Erva ereta, possivelmente anual, 7-12 cm alt., não ramificada; caule delgado, viloso, simples, claramente visível, entrenós 1-2,5 cm compr. Estípulas inconspícuas, triangulares, hirsutas. Folhas opostas, decussadas, sésseis a curtamente pecioladas; pecíolo 0-0,5 mm compr.; lâmina oval, base amplexicaule, margem plana, ápice arredondado a acutiúsculo, 2,5-6 $\mathrm{mm}$ compr., 2-5 mm larg., cartácea, hirto-vilosa, tricomas patentes; venação acródroma, nervuras concolores quando secas, adaxialmente verdes e abaxialmente vináceas quando vivas, levemente salientes na face abaxial. Cimeiras terminais, amplamente ramificadas, com glomérulos terminais bracteados; flores sésseis; hipanto zigomorfo, 1,3-1,8 $\mathrm{mm}$ compr., $1 \mathrm{~mm}$ larg., lacínios 2, externamente estrigosos; corola alva com fauce azulada, $4-4,5 \mathrm{~mm}$ compr., 1,5-2 mm larg., externamente vilosa; lobos suberetos, triangulares, $1-1,5 \mathrm{~mm}$ compr., anteras subsésseis, inclusas; estilete exserto. Cápsula não observada.

Material examinado: Santana de Pirapama, Capela de São José, Trilha da Senhorinha, caminho para Congonhas

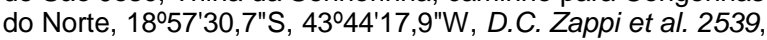
25.XI.2009, fl. (K, SPF); Cabeceira do Coberto, Mina de Manganês da Femavit, acima da nascente do Ribeirão Coberto, D.C. Zappi 850, 28.VIII.2007, fl. (K, SPF).

Material adicional: Minas Gerais: Santo Antônio do Itambé, Parque Estadual do Itambé, ca. 1823'55,6"S, 4320'26,3"W, J.R. Pirani et al. 5949, 10.II.2009, fl. (SPF).

Steyermark \& Kirkbride (1977) diferenciam $P$. parviflora de $P$. irwiniana principalmente pelo hábito (plantas até $27 \mathrm{~cm}$ e eretas em oposição a plantas maiores e decumbentes), pelas dimensões do tubo (3$3,5 \times 5 \mathrm{~mm}$ compr.) e pela coloração das flores (alva $\times$ rosada), além da presença de conectivo em $P$. parviflora. P. parviflora foi coletada na Serra do Caraça, enquanto $P$. irwiniana era proveniente do Pico do Itambé. Ambas as espécies estavam representadas apenas pelo material-tipo, e o estudo de exsicatas adicionais mostrou que as características utilizadas para diferenciá-las são variáveis, sendo que o espécime Pirani et al. 5949 é composto por plantas de diferentes tamanhos, florescendo de 15 a $60 \mathrm{~cm}$ alt., e Zappi 2613 possui flores alvo-azuladas. Além disso, foi observado conectivo nas anteras do material proveniente do Itambé (Pirani et al. 5949), que teoricamente não deveria apresentar conectivo expandido. Dessa forma, optou-se por sinonimizar $P$. irwiniiana sob $P$. parviflora. $\mathrm{Na}$ Serra do Cipó, $P$. parviflora cresce em campos pedregosos no topo de pequenos morros, entre cascalho quartzítico e com pouca cobertura vegetal, florescendo em agosto e novembro.

26.3. Perama sparsiflora Standl. ex Steyerm. \& J.H. Kirkbr., Brittonia 29: 196. 1977.

Fig. 8. C.

Erva perene, ereta, $10-30 \mathrm{~cm}$ alt., crescendo em touceiras compactas; caule delgado, hirsuto, muito ramificado, encoberto pelas folhas adpressas, entrenós com menos de $1 \mathrm{~cm}$ compr. Estípulas inconspícuas, hirsutas. Folhas sésseis a subsésseis, opostas, patentes a subreflexas, não cobrindo os ramos; lâmina linear-lanceolada a oval, base aguda a atenuada, margem plana, ápice agudo, 6-10 mm compr., 2-6 mm larg., cartácea, castanho-amarelada quando seca, densamente coberta por tricomas semieretos, híspidos, amarelados a ferrugíneos; nervuras inconspícuas. Inflorescências axilares, paucifloras; 


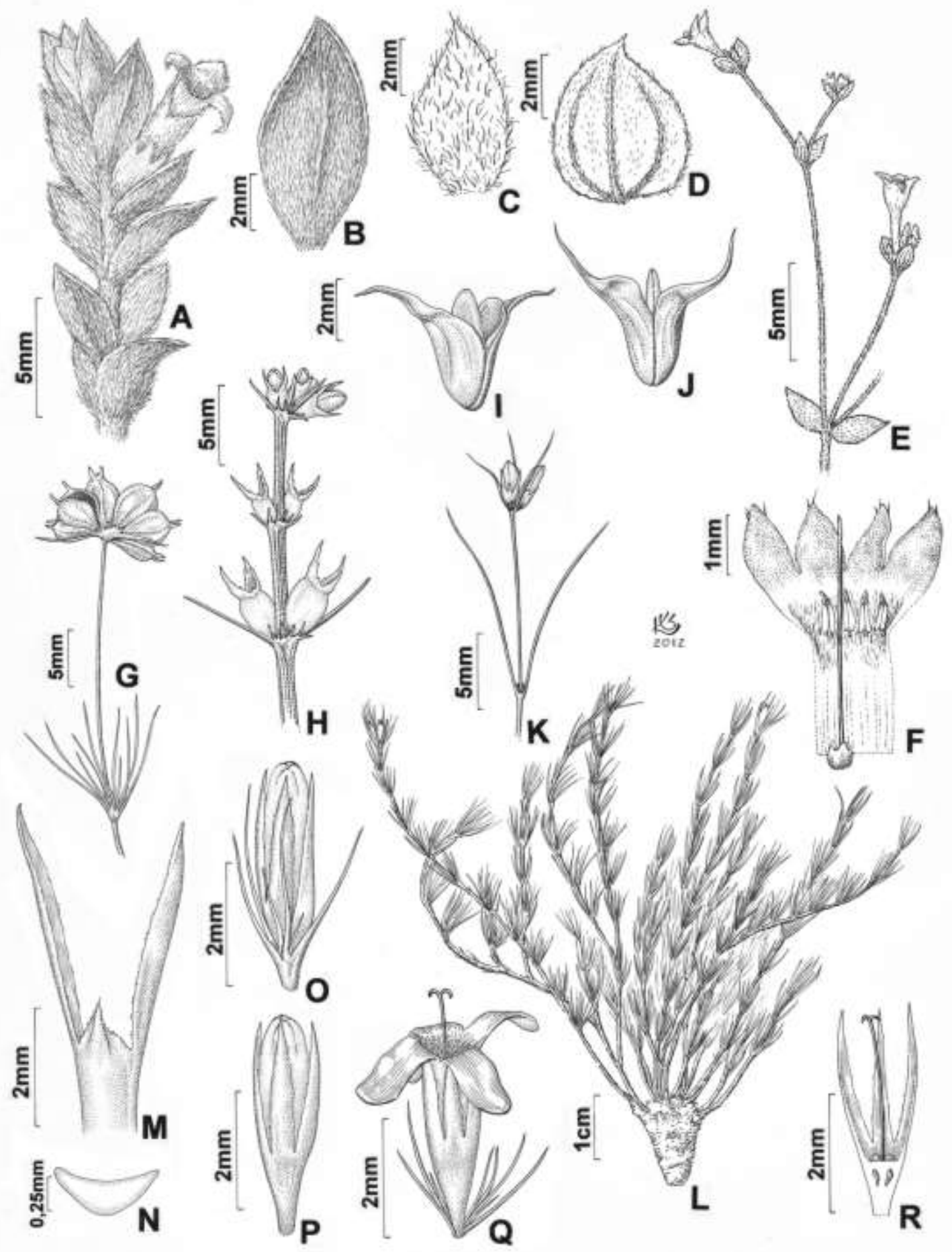

Fig. 8 - Herbáceas ou subarbustivas, frutos que não se dividem em mericarpos. A-B. Perama holosericea. A. Hábito. B. Folha. C. Perama sparsiflora, Folha. D-F. Perama parviflora. D. Folha. E. Hábito. F. Flor aberta. G. Psyllocarpus asparagoides, Infrutescência. H-J. Psyllocarpus laricoides. H. Ápice do ramo. I-J. Frutos abertos. K. Psyllocarpus schwackei, Ápice do ramo. L-R. Psyllocarpus densifolius sp. nov. L. Hábito. M. Folhas e estípula. N. Corte transversal da folha. O. Botão floral protegido por brácteas. P. Botão floral, brácteas removidas. Q. Flor. R. Hipanto em corte longitudinal. (A-B: Zappi 2613. C: Glaziou 19463. D-F: Zappi 2539. G: Irwin 21998. H-J: Zappi 1516. K: Duarte 9697. L-R: Zappi 1919). 
flores sésseis; hipanto zigomorfo, $2 \mathrm{~mm}$ compr., $1 \mathrm{~mm}$ larg., lacínios 2, externamente híspidos; corola alva, 4$5 \mathrm{~mm}$ compr., ca. $2 \mathrm{~mm}$ larg., externamente estrigosa a vilosa; lobos patentes, triangulares, ca. $1 \mathrm{~mm}$ compr.; anteras inclusas, subsésseis; estilete exserto. Cápsula $4 \mathrm{~mm}$ compr.; sementes obovais a prismáticas, castanhas, $1 \mathrm{~mm}$ diâm.

Material examinado: Congonhas do Norte, Serra da Mangabeira, margem direita do Rio Preto, A. Furlan et al. CFSC 8454, 23.IV.1982, fl. (SPF); Serra da Carapina (Serra Talhada segundo folha do IBGE), 1852'S, 4314'W, R.C. Forzza et al. 692, 2.III.1998, fl. (SPF). Santana do Riacho, 7$12 \mathrm{~km} \mathrm{~N}$ da cidade em direção à Lapinha, 1910'S, 43ㄴ1'W, M.M. Arbo et al. 4868, 11.Il.1991, fl., fr. (CTES, SPF); Serra da Lapinha, J.R. Pirani et al. CFSC 12137, 27.III.1991, fl., fr. (SPF); estrada Belo Horizonte-Conceição do Mato Dentro, km 119, 1914'58"S, 4332'41"W, V.C. Souza et al. 28599, 28.II.2002, fl. (CTES, ESA, SPF); idem, km 123, R. SimãoBianchini et al. CFSC 11507, 21.V.1989, fl., fr. (NY, RB, SPF); idem, km 126, F. Barros 1335, 2.Il.1987, fl., fr. (SP); Alto do Palácio, M.M. Arbo et al. 4261, 16.V.1990, fl., fr. (CTES, SPF); idem, N.L. Menezes et al. CFSC 9571, 27.I.1986, fl., fr. (SPF); idem, km 125, J.R. Pirani et al. CFSC 12811, 7.XII.1991, fl., fr. (K, SPF, UB); s.I., Glaziou 19463, s.d., fl. (G, K, P); rodovia Lagoa Santa - Conceição do Mato Dentro - Diamantina, km 132, N.L. Menezes et al. CFSC 5821, 18.XII.1979, fl., fr. (SP); RPPN Brumas do Espinhaço e Ermo do Gerais, M.G.C.Fernandes et al. 1727, 27.XI.2012, fl. (BHZB, SPF); idem, M.G.C. Fernandes et al. 402, 31.I.2013, fl. (BHZB, SPF). Sem município, Serra do Cipó, km 138, Barreto \& Brade 1134, 15.IV.1935, fl. (BHCB, RB, isótipos).

Material adicional: Minas Gerais. São Roque de Minas, Parque Nacional da Serra da Canastra, R. Romero et al. 1926, 17.III.1995, fl. (HUFU, RB).

Abundantemente ramificada, $P$. sparsiflora difere de $P$. holosericea devido ao aspecto de seu indumento, que é hirto e não adpresso. Considerada até o presente como endêmica da Serra do Cipó (Steyermark \& Kirkbride 1977), foi registrada agora também na Serra da Canastra no oeste de Minas Gerais. Na Serra do Cipó, é encontrada em locais elevados, em campo rupestre, florescendo e frutificando de dezembro a maio.

\section{Posoqueria Aubl.}

Árvores ou arvoretas geralmente glabras, fuste reto; ramos cilíndricos com nós evidentes. Estípulas oblongas, ovadas ou espatuladas, persistentes. Folhas opostas decussadas, pecioladas, firmemente cartáceas a coriáceas, geralmente arredondadas, domácias ausentes. Inflorescências em cimeiras corimbosas terminais, pedunculadas. Flores bissexuadas, levemente zigomorfas, 5-meras; corola alva com prefloração imbricada, tubo longo e estreito, hipocrateriforme; estames exsertos, com antese explosiva; ovário 2-locular (unilocular pelo desenvolvimento incompleto do septo), lóculos pluriovulados; estilete incluso, estigma bífido; disco anular. Bagas suculentas, globosas a irregulares, com poucas sementes tetraédricas cartilaginosas, envolvidas por polpa adocicada.

27.1. Posoqueria latifolia (Rudge) Schult., J.J.Roemer \& J.A.Schultes, Syst. Veg. 5: 227. 1819.

Nome vulgar: laranja-de-macaco.

Fig. 1. G.

Árvore, 2,5-8 $\mathrm{m}$ alt.; ramos cilíndricos, levemente estriados, glabros, nós evidentes. Estípulas persistentes até o terceiro nó, oblongas a ovadas, ápice agudo, glabras externamente, 3-5,5 mm compr. Folhas pecioladas; pecíolo 8-10 mm compr.; lâmina elíptica a oval, base obtusa a arredondada, às vezes subcordada, margem espessada, ápice obtuso a acutiúsculo, 7-18 x (3-)4,5-9(-10) cm, subcoriácea a coriácea, discolor, glabra; venação broquidódroma, nervuras secundárias pouco conspícuas, domácias ausentes. Cimeiras 8-10-floras, pedúnculo até $2 \mathrm{~cm}$ compr.; flores alvas a creme, odoríferas; hipanto 3-3,5 $\mathrm{mm}$ compr., lobos 1-1,5 mm compr., deltoides a obtusos; corola 10-15 cm compr., glabra externamente, internamente papilosa e com anel de tricomas longos na base, lobos 12-20 x 4-8 mm, oblongos a ovado-lanceolados, fortemente reflexos na antese; filetes 4-7 mm compr., anteras dorsalmente pilosas. Baga irregularmente globosa, verde passando a amarelo-alaranjada, glabra, 2,4-3,5 cm diâm., cálice persistente; sementes $8-15$, poliédricas, ca. 10 $\mathrm{mm}$ compr.

Material examinado: Jaboticatubas, Serra do Cipó, rodovia Lagoa Santa - Conceição do Mato Dentro Diamantina, km 126, J. Semir et al. 4435, 6.IX.1973, fr. (SP); idem, km , J.R. Pirani 5947, 29.II.1980, fr. (SP); idem, km 142, J. Semir \& D.A. Lima 4853, 10 a 15.XII.1973, fl. (SP, UEC). Santana do Riacho, Serra do Cipó, L.S. Kinoshita \& K. Matsumoto 00/528, 22.XI.2000, fl. (UEC); rodovia Belo Horizonte - Conceição do Mato Dentro, km 107, J.R. Pirani et al. CFSC 7460, 4.X.1981, fl. (SPF, UEC); idem, km 109, E. Forero et al. 7839 (CFSC 8745), 6.IX.1980, fl. (SP, SPF); idem, entre km 110 e 111, próximo do Córrego Duas Pontinhas, J.R. Pirani et al. CFSC 11029, 11.I.1988, fr. (SPF); idem, 1919'S, 4334'W, J.R. Pirani \& R. Mello-Silva CFSC 11315, 24.III.1989, fr. (SPF); idem, km 114, J.R. Pirani \& M.C. Amaral CFSC 5858, 19.XII.1979, fr. (SP); idem, km 125, Alto do Palácio, próximo à estátua do Velho Juca, M.T.V.A. Campos et al. CFSC 12810, 7.XII.1991, fl. (SPF); idem, M.T.V.A. Campos et al. CFSC 12892, 7.III.1992, fr. (SPF); idem, km 126 ( $2^{\circ}$ ponte), M.G.L. Wanderley CFSC 10672, 7.IV.1987, fr. (SP); estrada MG-010 cerca de $400 \mathrm{~m}$ antes da bifurcação entre o Morro do Pilar e Conceição do Mato Dentro, M.T.V.A Campos CFSC 13440, 23.IX.1993, fr. (SPF); RPPN Brumas do Espinhaço e Ermo do Gerais, G.A. Ferreira Junior 591, 11.IX.2012, fr. (BHZB, SPF); idem, M.G.C. Fernandes et al. 1729, 27.XI.2012, fl. (BHZB, SPF).

Material adicional: Minas Gerais: Joaquim Felício, Serra do Cabral, A.M. Giulietti et al. CFCR 6376, 23.XI.1984, fl. (K, SPF). 
Espécie com ampla distribuição na Região Neotropical, ocorrendo desde o sul do México até o sul do Brasil (Govaerts 2013), Posoqueria latifolia é fácil de reconhecer pelas suas longas flores zigomorfas, folhas amplas, geralmente coriáceas, e fruto bacáceo de mais de $2 \mathrm{~cm}$ de diâm. Na Serra do Cipó, ocorre em mata ciliar e capão de mata, florescendo de setembro a dezembro e frutificando de setembro a abril.

\section{Psychotria $\mathrm{L}$.}

Subarbustos ou arbustos, raramente arvoretas ou árvores. Estípulas interpeciolares geralmente bipartidas a bífidas (inteiras e espatuladas em $P$. carthagenensis), livres ou conatas, usualmente decíduas, glabras ou pubescentes. Folhas opostas, raramente sésseis, glabras ou pubescentes. Inflorescências geralmente terminais, muito raramente subterminais ou axilares, cimosas ou tirsos, ocasionalmente agrupadas em corimbos ou capitadas e acompanhadas de brácteas involucrais; flores bissexuadas, actinomorfas, heterostílicas, pequenas, 5(6)-meras, frequentemente alvas, azuladas ou amareladas; lacínios variáveis, glabros ou pubescentes; corola com prefloração valvar, hipocrateriforme, base estreita, glabra ou pubescente; estames 5, inseridos na região da fauce da corola; ovário 2(-3-5)-bicarpelar, lóculos uniovulados. Fruto drupa com 2(-5) pirênios; sementes com face ventral profundamente sulcada.

Chave para as espécies

1. Estípulas inteiras, espatuladas; folhas secando castanho-avermelhadas a enegrecidas, concolores;

frutos amarelados passando a avermelhados

28.2. P. carthagenensis

1'. Estípulas bífidas ou bilobadas; folhas secando verde-acastanhadas a oliváceas, geralmente

discolores; frutos verdes passando a alvos, azuis, violáceos ou atropurpúreos.

2. Nervuras secundárias e terciárias paralelas e indistinguíveis entre si; inflorescências axilares e subterminais 28.13. P. vellosiana

2'. Nervuras secundárias distintas das terciárias; inflorescências geralmente terminais.

3. Ramos, folhas e brácteas densamente tomentosos 28.11. P. stachyoides

3'. Ramos, folhas e brácteas glabros, raramente levemente pilosos, mas nunca densamente tomentosas.

4. Inflorescências sésseis, 1-4(-5)-floras.

5. Brácteas conspícuas envolvendo as flores

5 '. Brácteas curtas, não envolvendo as flores.

28.10. P. cf. spathicalyx

6. Hipanto vermelho, com lobos expandidos; corola amarelo-alaranjada 28.8. P. nuda

6 '. Hipanto verde, inconspícuo; corola alva a creme

4'. Inflorescências geralmente pedunculadas, 5-multifloras.

7. Ramos quadrangulares, alados

7'. Ramos cilíndricos ou aplanados, não alados.

8. Inflorescências com brácteas conspícuas, às vezes fundidas na base.

9. Estípulas 6-10(-15) mm compr.; folhas com mais de 10 pares de nervuras secundárias; inflorescências alvas a verde-claras com brácteas não involucrais

28.1. P. capitata

9'. Estípulas 2-4 mm compr.; folhas com (4-)6-7 pares de nervuras secundárias; inflorescências avermelhadas, com brácteas involucrais ....

'. Inflorescências sem brácteas visíveis ou com brácteas pouco conspícuas.

10. Inflorescências cimosas, dicasiais a corimbiformes.

11. Folhas lineares com menos de $1 \mathrm{~cm}$ larg.

28.5. P. microcarpa

11 . Folhas lanceoladas a ovais, normalmente com mais de $2 \mathrm{~cm}$ larg.

12. Folhas lanceoladas a estreitamente elípticas; pecíolo $0,5-1 \mathrm{~cm}$ compr. ...................28.7. P. nemorosa

12 . Folhas ovais; pecíolo ausente a $1 \mathrm{~mm}$ compr.

10'. Inflorescências em tirsos alongados, mais longas do que largas.

13. Inflorescência piramidal, com ramos laterais desenvolvidos, os basais ramificados

13'. Inflorescência cilíndrica, com ramos laterais curtos, não ramificados

28.6. P. myriantha 28.3. P. forsteronioides

28.1. Psychotria capitata Ruiz \& Pav., Fl. Peruv. 2: 59.1799.

Fig. 9. G.

Subarbustos ou arbustos 0,40-3 m alt.; ramos cilíndricos, glabros. Estípulas bipartidas a partir da base, persistentes ou decíduas a partir do segundo nó,
6-10(-15) x 4-5 mm, lobos longamente aristados, glabros. Folhas opostas, subsésseis a curtamente pecioladas; pecíolo 0-2 $\mathrm{mm}$ compr.; lâmina estreitamente lanceolada, elíptica ou oboval, base truncada, arredondada ou atenuada, margem plana, ápice agudo a acuminado, (4,5-)6-10(-12) cm compr., 1-3(-4) cm larg., finamente cartácea, discolor ou 
concolor, glabra; venação broquidódroma, nervuras secundárias (10-)12-20 pares, arqueadas, aproximadas, planas a salientes em ambas as faces, nervuras intersecundárias e retículo visíveis. Inflorescências terminais, em cimeiras sub-umbeladas, alvas a verde-claras, multifloras, pedunculadas, pedúnculo (1,5-)2-4 cm compr., com (3-)6-7 ramos terminando em cimeiras 5-floras, ramificações e flores acompanhados por brácteas não involucrais alvas, estreitamente lanceoladas, (5-)6-10 mm compr., 1-2 $\mathrm{mm}$ larg.; flores 5-meras, sésseis; tubo do cálice lobado até a metade de sua extensão, lacínios triangulares, diminutamente ciliados, ca. 0,6 mm compr., ca. 0,8 mm larg.; disco bilobado; corola alva, 7$8 \mathrm{~mm}$ compr., 4-5 mm larg., glabra a ligeiramente pilosa no ápice, lobos patentes a reflexos; estames exsertos nas flores brevistilas, subinclusos nas flores longistilas; estigma bífido, glabro. Drupa subglobosa, bilobada, sulcada, verde passando a vinácea ou acastanhada quando madura, 4-5 mm compr., 5-6 mm diâm.

Material examinado: Jaboticatubas, Serra do Cipó, estrada para a sede do IBAMA, 1920'S, 4337'W, L.S. Kinoshita \& L.Y.S. Aona 00/130, 21.XI.2000, fl. (UEC); idem, L.S. Kinoshita \& L.Y.S. Aona 00/153, 21.XI.2000, fl. (UEC); subida vulgarmente conhecida como Subida do Caramba, em direção à Serra da Bandeirinha, próximo ao Córrego Grande, P. Hervencio et al. 100, 20.X.1997, fl. (SPF); rodovia Belo Horizonte - Conceição do Mato Dentro, km 112, M. Sakane CFSC 658, 25.X.1977, fl. (SP, SPF). Santana de Pirapama, Serra do Cipó, acesso pela Faz. Inhame, Córrego do Quartel, 185'ㄱ'"S, 4346'44"W, D.C. Zappi et al. 1756, 6.III.2009, fl., fr.(K, RB, SPF). Santana do Riacho, Rio Cipó, 1920'S, 433' W, J.R. Pirani \& I. Cordeiro 5056, 7.III.2002, fl. (K, SPF); idem, km 106, J.R. Pirani et al. CFSC 6812,

14.XII.1980, fl. (SP, SPF); rodovia Belo Horizonte Conceição do Mato Dentro, km 115, J.R. Pirani \& L. Rossi CFSC 9219, 14.XI.1983, fl. (MO, SPF); Estrada da Usina, mata ciliar do ribeirão Indequicé, V.C. Souza et al. CFSC 9460, 14.XII.1985, fl. (MO, SPF); estrada para a Lapinha, C.F. Muniz et al. CFSC 7888, 18.II.1982, fr. (MO, SPF); na ACM, C.G. Gomes et al. 53, 23.X.2001, fl. (SPF); estrada de terra Cardeal Mota - São José da Serra, ca. $3 \mathrm{~km}$ da igreja, A.A. Grillo et al. CFSC 13952, 8.IV.1995, fr. (SPF).

Amplamente distribuída na América do Sul, no leste do Brasil a espécie está associada à Mata Atlântica, ocorrendo também em matas ciliares no Planalto Central (Barbosa et al. 2014). Na Serra do Cipó, ocorre em matas ciliares e capões de mata, florescendo entre outubro a março, tendo sido coletada com frutos de fevereiro a abril.

28.2. Psychotria carthagenensis Jacq., Enum. Syst. PI. insulis Caribaeis p. 16. 1760.

Fig. 9. A, H.

Arbustos a árvores, 1,2-6 m, glabros; ramos cilíndricos, finamente estriados. Estípulas inteiras, decíduas, espatuladas, 8-15 x 4-8 mm. Folhas opostas, pecioladas; pecíolo (0,5-)1-2,5 cm compr.; lâmina elíptica, lanceolada, oval ou oboval, base atenuada a cuneada, margem plana, ápice acuminado a acutiúsculo, (6-)8-16(-18) cm compr., (2-)3-6 cm larg., membranácea, concolor, secando castanhoavermelhada clara a enegrecida, glabra; venação broquidódroma, nervuras secundárias (6-)7-9 pares, oblíquas, distanciadas, salientes na face abaxial, planas na face adaxial, retículo pouco conspícuo. Inflorescências terminais, do tipo tirso, piramidais, verde-claras a alvas; pedúnculo $1-6(-8) \mathrm{cm}$ compr. ramificada em 2-4 ordens acima do pedúnculo; brácteas naviculares ou espatuladas, $3 \mathrm{~mm}$ compr.; flores 5-meras, sésseis a curtamente pediceladas; hipanto 1-1,5 x $1 \mathrm{~mm}$, tubo do cálice expandido, lobos denteados, irregulares; corola alva, $4 \mathrm{~mm}$ compr., 22,5 mm larg., glabra externamente, pilosa internamente abaixo da inserção dos estames, lobos suberetos; estames subinclusos; estigma bífido, incluso, glabro. Drupas globosas, lisas quando secas, amarelas passando a avermelhadas, 7-9 $\mathrm{mm}$ compr., 6-9 mm diâm.

Material examinado: Itambé do Mato Dentro, Distr. Santana do Rio Preto, APA do Parque Nacional da Serra do Cipó, 1924'52"S, 4325'53"W, M.F. Santos \& H. Serafim 240, 13.III.2008, fl. (SPF); idem, M.F. Santos \& H. Serafim 267, 13.III.2008, fl. (SPF); idem, M.F. Santos \& H. Serafim 332, 16.III.2008, fl. (SPF). Jaboticatubas, Parque Nacional da Serra do Cipó, próximo à sede do IBAMA, J.R. Pirani et al. CFSC 12908, 7.III.1992, fr. (SPF); idem, 1920'S, 43ํ3'W, L.S. Kinoshita \& M.E. Alencar 00/356, 21.XI.2000, fl. (UEC). Santana de Pirapama, Serra do Cipó, acesso pela Faz. Inhame, povoado de Inhame, margem do Rio Cipó, 185'ㅇ'ㅇ, 4347'42"W, D.C. Zappi et al. 1778, 6.III.2009, fl. (K, RB, SPF); Distr. de São José da Cachoeira (Inhame), Faz. Toucan Cipó, beira do córrego a norte da Fazenda, 1859'24"S, 4346'31"W, D.C. Zappi 2291, 7.XI.2009, fl. (K, RB, SPF). Santana do Riacho, Parque Nacional da Serra do Cipó, trilha do Gavião, acesso pela portaria do Engenho, C.M. Siniscalchi \& M.F. Devecchi 99, 20.XII.2010, fl., fr. (SPF); rodovia Belo Horizonte - Conceição do Mato Dentro, km 111, estrada da Usina Dr Pacífico Mascarenhas, A.M. Giulietti et al. CFSC 6346, 22.VII.1980, fr. (SP, SPF); idem, entre o km 115 e a estrada da Usina, E.A. Anunciação 217, 1.V.1993, fl. (SP); idem, km 114, S. Mayo et al. CFSC 7029, 28.Il.1981, fl., fr. (MO, SPF); idem, km 104, Cachoeira da Mãe D'água, L. Rossi \& O. Oyakawa CFSC 9256, 23.I.1984, fl. (SPF); idem, km 106, J.R. Pirani et al. CFSC 6811, 14.XII.1980, fl. (SP, SPF).

Amplamente distribuída na América do Sul, no leste do Brasil está associada à Mata Atlântica, ocorrendo em matas ciliares no Planalto Central e na Amazônia (Barbosa et al. 2014). É possível que seja conspecífica com Psychotria alba Ruiz \& Pav. (1799) e Psychotria mapourioides DC. (1830), nomes usados no contexto do Brasil e da América do Sul, porém mais estudos são necessários para uma melhor compreensão dessas entidades taxonômicas. Na 


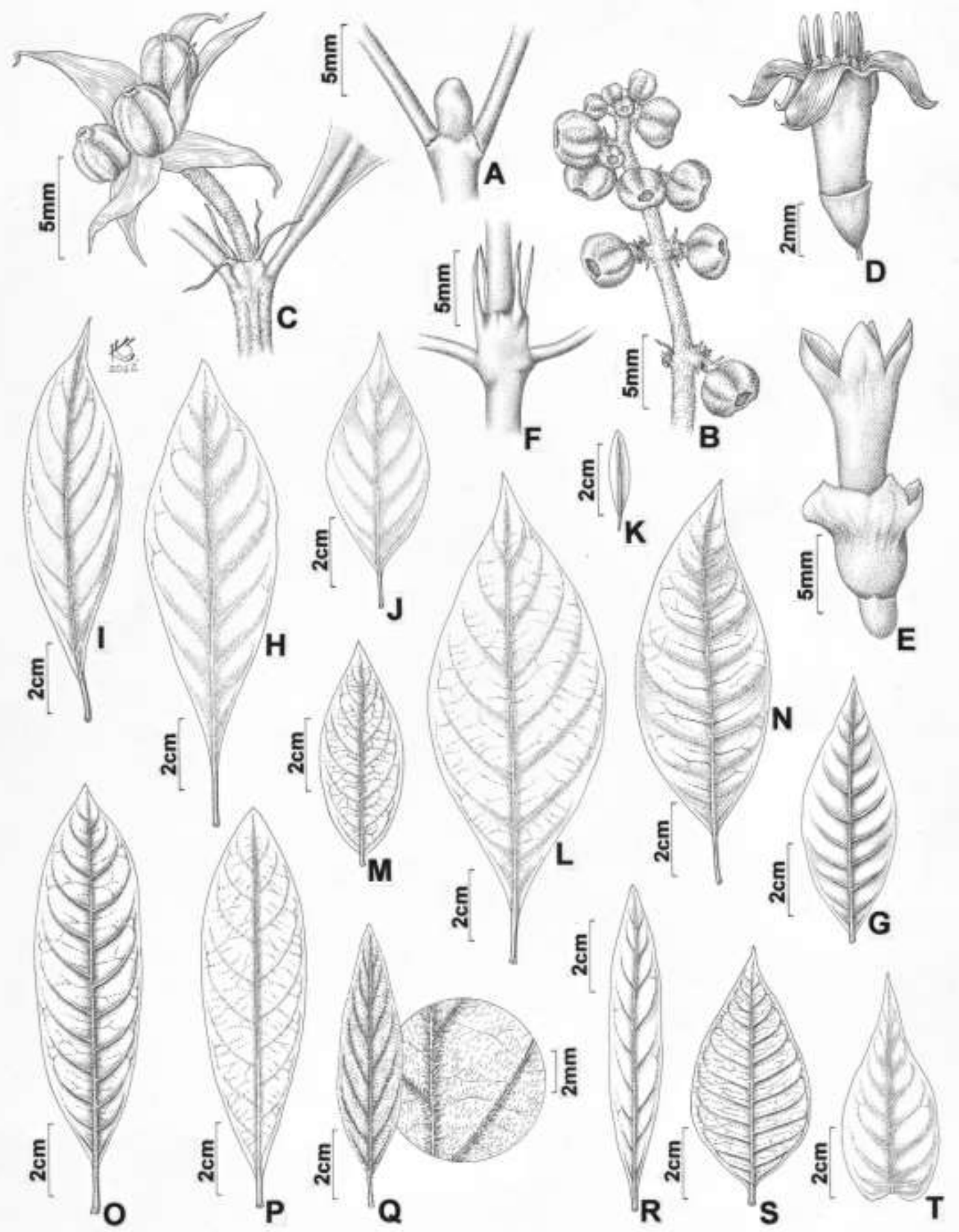

Fig. 9 - Arbustos a árvores, frutos drupáceos 2-seminados (Psychotria). A, H. Psychotria carthagenensis. A. Estípula. H. Folha. B, I. P. forsteronioides. B. Infrutescência. I. Folha. C, J. P. hoffmannseggiana. C. Infrutescência. J. Folha. D, O. P. pleiocephala. D. Flor. O. Folha. E, N. P. nuda. E. Flor. N. Folha. F, L. P. myriantha. F. Estípulas. L. Folha. G. P. capitata, Folha. K. P. microcarpa, Folha. M. P. nemorosa, folha. P. P. spathicalyx, folha. Q. P. stachyoides, Folha incluindo detalhe da face abaxial. R. P. subtriflora, Folha. S. P. vellosiana, Folha. T. P. warmingii, Folha. (A, H: Zappi 1778. B, I: Forzza 2988. C, J: Zappi 1832. D, O: Riina 1330. E, N: Gomes \& Laudicea 2747. F, L: CFSC 12873. G: Zappi 1756. K: Hatschbach 52934. M: Irwin 28476. P: Mello Barreto 8834. Q: CFCR 5990. R: Mello Barreto 8891. S: Pereira 909. T: Lombardi 4672). 
Serra do Cipó, foi coletada em mata ciliar e capão de mata, florescendo entre novembro e maio e frutificando em fevereiro, março e julho.

28.3. Psychotria forsteronioides Müll.Arg., Flora 59: 553. 1876. 1876.

Psychotria malaneoides Müll.Arg., Flora 59: 553.

Fig. 9. B, I.

Arbustos a arvoretas, 1,5-4 m alt.; ramos cilíndricos, os mais jovens pilosos especialmente nos nós. Estípulas bipartidas a partir da metade, persistentes, 4-6 x 2-4(-6) mm, lobos agudos, pilosos, tornando-se escariosas quando velhas. Folhas pecioladas; pecíolo 0,5-0,8 cm compr.; lâmina elíptica a lanceolada, base atenuada, margem plana a levemente revoluta, ápice acuminado, (4-)5-9(-10) cm compr., (1-)1,5-3 cm larg., membranácea a subcartácea, levemente discolor ou concolor, pilosas a glabrescentes; venação eucamptódroma, nervuras secundárias (9-)10-12 pares, arqueadas, distanciadas, salientes na face abaxial, planas na face adaxial, nervuras intersecundárias visíveis, retículo obscuro. Inflorescências terminais, do tipo tirso, estreitas, verde-claras, densamente pilosas; pedúnculo (0,5-)1$1,5 \mathrm{~cm}$ compr., ramificada em $3-5$ ordens acima do pedúnculo, 3-8-floros; brácteas ausentes, bractéolas inconspícuas; flores 5-meras, sésseis a curtamente pediceladas; tubo do cálice ausente, lacínios denteados, irregulares, ciliados, ca. 0,3 mm compr., ca. 0,5 mm larg.; disco inteiro; corola alva, 4-4,5 mm compr., 2-2,5 mm larg., glabra externamente, pilosa internamente abaixo da inserção dos estames, lobos suberetos; estames subinclusos; estigma bífido, incluso, glabro. Drupas bilobadas, sulcadas quando secas, arroxeadas passando a negras quando maduras, 3,5-4 mm compr., 4-5 mm diâm.

Material examinado: Santana do Riacho, Serra do Cipó, rodovia Belo Horizonte - Conceição do Mato Dentro, km 125, M.C.Henrique \& J.R. Pirani CFSC 5793, 18.XII.1979, fl. (SP, SPF); idem, km 135, Palácio, 1849'S, 43ํํ'W, H.S. Irwin et al. 20564, 20.II.1968, fl. (NY, UB); idem, km 128, J.R. Pirani et al. CFSC 9766, fl., fr. (SPF); idem, km 145, Fazenda Boa Esperança, N. Roque et al. 125, 13.Il.1996, fl. (SPF); idem, N. Roque et al. 131, 13.II.1996, fl. (SPF).

Material adicional: Minas Gerais: Belmiro Braga, estrada para Monte Verde, $21^{\circ} 57^{\prime} \mathrm{S}, 43^{\circ} 29^{\prime} \mathrm{W}$, R.C. Forzza et al. 2988, 8.III.2008, fr. (K, RB); Serro, $30 \mathrm{~km} \mathrm{~N}$ of Serro on MG02 to Diamantina, H.S. Irwin et al. 20915, 26.II.1968, fl. (K, NY); Diamantina, $7 \mathrm{~km} \mathrm{NE}$ of Diamantina on road to Mendanha, H.S. Irwin et al. 22810, 29.I.1969, fl. (K, NY, UB); São João da Chapada, $3 \mathrm{~km} \mathrm{~N}$ of town on road to Inhaí, H.S. Irwin et al. 24886, 28.II.1970, fr. (K, NY, UB). São Paulo, Tapiraí, rodovia SP 79, após a saída da cidade em direção a Juquiá, propriedade da São José Administração e Matérias Primas, R. Mello-Silva et al. 912, 11.V.1994, fr. (SPF).

Psychotria forsteronioides ocorre no leste do Brasil, na Bahia, Minas Gerais, Rio de Janeiro, São Paulo, Paraná e Santa Catarina (Barbosa et al. 2014). Os materiais provenientes da Cadeia do Espinhaço apresentam folhas mais rígidas e abaxialmente pubescentes quando comparados àqueles coletados na Mata Atlântica.

28.4. Psychotria hoffmannseggiana (Willd. ex Roem. \& Schult.) Müll.Arg. in Mart, Eichler \& Urb., FI. bras. 6(5): 336. 1881.

Fig. 9. C, J.

Subarbustos ou arbustos 0,3-2 m alt.; ramos cilíndricos, glabros. Estípulas bipartidas a partir da base, decíduas, 1-4 × 2-4 mm, lobos dentiformes, glabros. Folhas opostas, pecioladas; pecíolo 8-12 mm compr.; lâmina lanceolada a oval, base atenuada a decorrente, margem plana a ligeiramente revoluta, ápice longamente acuminado, 4-8 cm compr., 1-2,5 cm larg., subcartácea, concolor, glabra; venação broquidódroma, nervuras secundárias (4-)6-7 pares, oblíquas, espaçadas, salientes na face abaxial, planas na face adaxial, retículo evidente na face abaxial. Inflorescências terminais, cimosas arredondadas, avermelhadas, pedunculadas; pedúnculo $0,8-1,2 \mathrm{~cm}$ compr., piloso, terminando em cimeiras (3-)5-floras, glomeruloides, envolvidas por 4(-6) brácteas alvas a róseas, ovais a lanceoladas, 5-7 mm compr., 2-4 mm larg.; flores 5(-6)-meras, sésseis; hipanto turbinado, 2 $\mathrm{mm}$ compr., lacínios levemente ondulados, ciliados, ca. $1 \mathrm{~mm}$ compr., ca. $1 \mathrm{~mm}$ larg.; corola alva, 4-4,5 $\mathrm{mm}$ compr., 2-3 mm larg., esparsamente pilosa, principalmente no ápice dos lobos e interior do tubo, lobos reflexos; estames subsséseis nas flores longistilas; estigma bífido, piloso, exserto nas flores longistilas. Drupas globosas a subglobosas, ligeiramente sulcadas quando secas, azuis a vináceas quando maduras, 2-3 mm compr., 2-4 mm diâm.

Material examinado: Santana de Pirapama, Serra do Cipó (Serra da Lapa), estrada Santana do Riacho Santana do Pirapama, trecho de São José da Cachoeira Inhame, Cachoeira Bonita, 1858'40"S, 4346'35"W, V.C. Souza et al. 32633, 18.II.2007, fr. (ESA, K); acesso pela Faz. Inhame, E.S. Cândido et al. 534, 20.III.2011, fr. (SPF); Córrego do Quartel, 1858'31"S, 4346'44"W, D.C. Zappi et al. 1757, 6.III.2009, fr. (K, RB, SPF); estrada entre Capela de São José e Santana do Riacho, Faz. Toucan Cipó, 1859'26"S, 4346'38"W, D.C. Zappi et al. 1832, 7.III.2009, fr. (K, RB, SPF). Santana do Riacho, Serra do Cipó, estrada de terra Cardeal Mota - São José da Serra, ca. de $3 \mathrm{~km}$ da igreja, M. Sztutman et al. CFSC 13954, 8.IV.1995, fl. (SPF); rodovia Belo Horizonte Conceição do Mato Dentro, Ribeirão Indequicé, V.C. Souza et al. CFSC 9460-A, 14.XII.1985, fl. (SPF); idem, N.L. Menezes et al. CFSC 7112, 2.III.1981, fr. (SPF); Estrada da Usina, J.R. Pirani \& R. Altikes CFSC 5942, 19.XII.1979, fl. (SP, SPF); idem, km 115, Estrada da Usina, J.R. Pirani \& L. Rossi CFSC 9218, 14.XI.1983, fl. (SPF); idem, A.M. Giulietti et al. CFSC 7399, 1.VII.1981, fr. (MO, SPF); Vale do Rio Cipó, $2 \mathrm{~km} \mathrm{E}$ da base do IBAMA, J.R. Pirani et al. CFSC 11876, 24.III.1991, fr. (MO, SPF); Mãe d'Água, vale d córrego do Véu da Noiva, J.R. Pirani CFSC 11477, 21.V.1989, fl., fr. (SPF); 7-12 km $\mathrm{N}$ de Santana do Riacho, caminho para Lapinha, ca. 1910'S, 4341'W, M.M. Arbo et al. 4881, 11.II.1991, fr. (CTES, SPF). 
Flora da Serra do Cipó, Minas Gerais: Rubiaceae

Material adicional: Conceição do Mato Dentro, Ouro Fino, caminho para Congonhas do Norte, 1856'S, 4336'W, M.M. Arbo et al. 4989, 13.II.1991, fr. (CTES, SPF).

Amplamente distribuída no leste da América do Sul, $P$. hoffmannseggiana ocorre em todos os biomas brasileiros. Psychotria tenerior (Cham.) Müll. Arg. é uma espécie semelhante a $P$. hoffmannseggiana, mas, segundo Taylor (2007), diferencia-se da mesma pelas inflorescências mais largas e pelo hipanto maior (8 $\mathrm{mm}$ compr. em $P$. tenerior). Na Serra do Cipó, $P$. hoffmannseggiana foi coletada em mata ciliar, com flores em novembro, dezembro, abril e maio, frutificando de fevereiro a julho.

28.5. Psychotria microcarpa Müll. Arg. in Mart., Eichler \& Urb., FI. bras. 6(5): 282. 1881.

Fig. 9. K.

Arbustos a subarbustos glabros, 0,5-1,5 m alt.; ramos delgados, cilíndricos. Estípulas bífidas, persistentes, 1 x 0,6-0,8 mm, lâmina ausente, lobos aciculares. Folhas opostas, curtamente pecioladas; pecíolo $1 \mathrm{~mm}$ compr.; lâmina linear a estreitamente lanceolada, base decorrente, margem plana a recurvada, espessada, ápice obtusiúsculo, 2-3,5 cm compr., 0,2-0,6 cm larg., membranácea a cartácea, discolor, face adaxial secando castanho-olivácea, face abaxial secando castanho-clara a amarelada, glabra; venação eucamptódroma, nervuras secundárias 6-9 pares, inconspícuas na face adaxial, salientes na face abaxial, intersecundárias presentes, retículo inconspícuo. Inflorescências terminais, dicasiais, multifloras, com 2(-3) níveis de ramificação; pedúnculo filiforme, 0,8-1,5 cm compr.; brácteas $1 \mathrm{~mm}$ compr., lineares, agudas; hipanto 1,2-1,5 mm compr., ca. 0,60,8 mm larg., tubo inconspícuo, truncado no ápice ou com lobos inconspícuos, irregulares; corola creme, 3 $\mathrm{mm}$ compr., ca. 1,5 mm larg., lobos reflexos, 1-1,5 mm compr.; estames subsséseis nas flores longistilas; estigma bífido, exserto nas flores longistilas. Drupas globosas a bilobadas, restos do cálice inconspícuos, lisas quando secas, azuis a lilás-arroxeadas quando maduras, 3 mm compr., 3-3,5 mm diâm.

Material examinado: Santana do Riacho, Serra do Cipó, rodovia Belo-Horizonte-Conceição do Mato Dentro MG010, km 112, Córrego Duas Pontinhas, A.A. Grillo et al. CFSC 13678, 5.IV.1990, fr. (SPF); idem, km 117, Córrego Alto do Cupim, A. Furlan et al. CFSC 7201, 19.IV.1981, fr. (MO, SPF); Morro do Breu, 1904'20"-05'20"S, 4339'20"40'20"W, N. Hensold 481 CFSC 8556, 16-17.II.1982, fr. (SPF); Alto do Palácio, rodovia Lagoa Santa a Conceição do Mato Dentro, km 126, F. Barros 1324, 2.II.1987, fl. (SP, SPF). Material adicional: Minas Gerais: Conceição do Mato Dentro, Pito Aceso, G. Hatschbach et al. 52934, 19.V.1989, fl., fr. (K, MBM, MO).

Esta espécie distingue-se das outras por suas folhas linear-lanceoladas, inflorescências filiformes e flores diminutas, e é possivelmente relacionada com Psychotria leiocarpa Cham. \& Schltdl. De distribuição esporádica e restrita a Minas Gerais e São Paulo, $P$. microcarpa é considerada extinta no último estado (Taylor 2007). Na Serra do Cipó, foi coletada em matas ciliares acima de $1200 \mathrm{~m}$ de altitude, frutificando entre fevereiro e abril.

28.6. Psychotria myriantha Müll.Arg., Flora 59: 549, 552. 1876.

Fig. 9. F, L.

Arbusto 1,5 m alt:; ramos cilíndricos, glabros. Estípulas bipartidas a partir da base, persistentes, 5-8 x 2-4 mm, lobos longamente aristados, glabros ou levemente pilosos internamente. Folhas pecioladas; pecíolo 1-2 cm compr.; lâmina elíptica, base atenuada, margem plana, ápice agudo a acuminado, 9-13 cm compr., 3-4,5 cm larg., membranácea, discolor ou concolor, glabra; venação broquidódroma, nervuras secundárias 10-12 pares, arqueadas, distanciadas, salientes na face abaxial, planas a salientes na face adaxial, nervuras terciárias paralelas, conspícuas. Inflorescências terminais, tipo tirso, estreitas, verdeclaras, glabras; pedúnculo (1,5-)2,5 cm compr., ramificada em 6-9 ordens acima do pedúnculo, ramos patentes a reflexos, de tamanho decrescente em direção ao ápice, terminando em cimeiras 3-5-floras; brácteas ausentes, bractéolas inconspícuas; flores 5meras, sésseis a curtamente pediceladas; tubo do cálice ausente, lacínios largamente triangulares a denteados, irregulares, glabros, ca. 0,3 mm compr., ca. 0,5 mm larg.; disco inteiro; corola alva, 4-4,5 mm compr., 2-2,5 mm larg., glabra externamente, pilosa internamente abaixo da inserção dos estames, lobos suberetos; estames subinclusos; estigma bífido, incluso, glabro. Drupas bilobadas, restos do cálice inconspícuos, lisas a levemente sulcadas quando secas, verdes a verde-amareladas quando imaturas, alvas quando maduras, 2,5-3 mm compr., 4,5-5 mm diâm.

Material examinado: Santana do Riacho, Serra do Cipó, rodovia Belo-Horizonte-Conceição do Mato Dentro MG010, Cardeal Mota, Morro da Pedreira, M.T.V.A. Campos et al. CFSC 12873, 7.I.1992, fl. (K, SPF).

Material adicional: Espírito Santo: Linhares, estrada para Colatina via Lagoa Nova, ca. $7 \mathrm{~km}$ E de Linhares, J.R. Pirani \& J.A. Kalunki 2631, 19.I.1993, fl. (K, MO, NY, SPF). Minas Gerais: Rio Branco, Retiro de Antonio Avelino, Y. Mexia 5489, 8.I.1931, fl. $(F, K)$. Rio de Janeiro: Santa Maria Madalena, Alto Imbé, $G$. Martinelli et al. 7592, 18.II.1981, fr. (K, RB).

Endêmica do Leste do Brasil (Santa Catarina, São Paulo, Rio de Janeiro, Minas Gerais, Espírito Santo e Bahia) (Barbosa et al. 2014), esta espécie foi coletada apenas uma vez na mata decídua sobre afloramento de calcário na base da Serra do Cipó, florescendo em janeiro. Psychotria myriantha assemelha-se a $P$. deflexa DC., uma espécie de ampla distribuição na Região Neotropical, da qual difere por suas folhas maiores, com maior número de nervuras secundárias (8-12) e venação terciária finamente paralela, enquanto $P$. deflexa apresenta folhas menores, com 6-8 pares de nervuras secundárias e venação terciária reticulada. 
28.7. Psychotria nemorosa Gardn., Hooker's J. Bot. Kew Gard. Mis. 4: 109. 1845.

Fig. 9. M.

Arbustos a subarbustos $1,5-2 \mathrm{~m}$ alt.; ramos delgados, cilíndricos, distalmente comprimidos. Estípulas bífidas, persistentes, $2-4$ × 1,5-3 mm. Folhas opostas, pecioladas; pecíolo $0,5-1 \mathrm{~cm}$ compr.; lâmina lanceolada a estreitamente elíptica, base aguda a decorrente, margem plana, ápice agudo a acuminado, 4-11 cm compr., 2-3 cm larg., membranácea, discolor, face abaxial secando castanho-olivácea a amarelada, face adaxial secando castanho-escura, glabra a esparsamente pilosa na face abaxial; venação eucamptódroma ou broquidódroma, nervuras secundárias 6-8 pares, salientes em ambas as faces, hirtelas abaxialmente, nervuras intersecundárias inconspícuas, retículo saliente abaxialmente. Inflorescências terminais, dicasiais, arredondadas, ramificada em 2-3 ordens acima do pedúnculo; pedúnculo 2,5-4 cm compr.; brácteas 1-5 mm compr., lineares, agudas; hipanto 1,5-2,2 mm compr., ca. 1,5 $\mathrm{mm}$ larg., tubo igual ao comprimento do hipanto, truncado no ápice ou com lobos inconspícuos, irregulares; corola creme, 7-9 mm compr., ca. $3 \mathrm{~mm}$ larg., lobos reflexos, com anel de tricomas interno; estames inseridos na porção mediana do tubo; estigma bífido, glabro Drupas globosas a bilobadas, coroadas pelos restos do cálice, lisas quando secas, azuis a arroxeadas quando maduras, $4-4,5 \mathrm{~mm}$ compr., 3,5-5 mm diâm.

Material examinado: Santana do Riacho, Serra do Cipó, MG 010, a $400 \mathrm{~m}$ da bifurcação para Morro do Pilar, a W da rodovia, M.T.V. Campos \& J.P.M. Garcia CFSC 13611, 27.I.1994, fl. (SP, SPF).

Material adicional: Bahia: Abaíra, Riacho da Taquara, L.P. Queiroz H51539,13.II.1992, fl. (CEPEC, HUEFS, K, SPF); idem, W. Ganev 3059, 11.IV.1994, fl. (HUEFS, K, SPF); Rio de Contas, Pico das Almas, R.M. Harley et al. 24533, 21.II.1987, fl. (CEPEC, K, SPF); idem, R.M. Harley et al. 27425, 22.XII.1988, fl. (CEPEC, K, SPF). Minas Gerais: São João da Chapada, road to Campo do Sampaio, $3 \mathrm{~km} \mathrm{~N}$ of town, H.S. Irwin et al. 28476, 28.III.1970, fr. (K, NY, UB); $27 \mathrm{~km} \mathrm{SW}$ de Diamantina na estrada para Gouveia, H.S. Irwin et al. 21816, 12.I.1968, fl. (K, NY, UB). Rio de Janeiro: Serra dos Órgãos, Gardner 454, I.1837, fl. (K, holótipo).

A morfologia dos espécimes de $P$. nemorosa coletados na Serra do Cipó coincide com aquela observada no material-tipo (Gardner 454). Taylor (2007) circunscreve esta espécie de modo a incluir Psychotria pubigera Schltdl., mas é possível que esta seja uma espécie distinta. Psychotria nemorosa é semelhante a Psychotria leiocarpa Cham. \& Schltdl., porém esta última apresenta flores com corola mais curta e inflorescências mais delicadas, e tem ocorrência na Mata Atlântica (RJ, SP). No passado, Zappi \& Stannard (1995) e Zappi et al. (2003) identificaram materiais provenientes da Chapada iamantina (Bahia) como P. leiocarpa, porém uma análise mais cuidadosa conduziu à transferência desses espécimes para Psychotria nemorosa. $\mathrm{Na}$ Serra do Cipó, esta espécie foi coletada apenas uma vez em capão de mata, florescendo em janeiro.

28.8. Psychotria nuda Wawra, Itin. Princ. S. Coburgi i. 128. 1883.

Nome vulgar: sonhos-de-ouro (Salimena s.n. in CESJ 20623)

Fig. 9. E, N.

Arbustos ou arvoretas glabras, 1-4 m alt.; ramos cilíndricos, levemente estriados, estreitados abaixo dos nós. Estípulas bipartidas próximo à base, lâmina bipartida, 1-2 x 4-5 mm, lobos denteados, 1-2 $\mathrm{mm}$ compr. Folhas opostas, pecioladas; pecíolo 6-12 $\mathrm{mm}$ compr.; lâmina elíptica a oval, base atenuada a decorrente, margem plana, ápice brevemente acuminado, 6-14 cm compr., 2-5 cm larg., membranácea, discolor, secando verde-pálida na face abaxial, verde-olivácea escura na face adaxial, glabras; venação broquidódroma, nervuras secundárias 9-12 pares, arqueadas, espaçadas, salientes em ambas as faces, nervuras intersecundárias conspícuas, retículo pouco evidente. Inflorescências terminais em glomérulos sésseis, 1-4(5)-floras; brácteas 1-3, basais, ovais, pouco conspícuas, 4-5 mm compr., verdes; flores 5-meras, sésseis; hipanto turbinado, com constrição abaixo dos lobos, vermelho, tubo 4-6 $\mathrm{mm}$ compr., lobos largamente triangulares a arredondados, ca. $3 \mathrm{~mm}$ compr., ca. 5-6 mm larg.; corola amarelo-alaranjada, 20-30 mm compr., 10-15 mm larg., carnosa, infundibuliforme, barbada na fauce, lobos suberetos; estames esxertos; estigma arredondado, incluso, glabro. Drupas ovoides, coroadas pelos restos do cálice, lisas quando secas, verde-azuladas a arroxeadas quando maduras, $16-22 \mathrm{~mm}$ compr., 6-8 mm diâm.

Material examinado: Itambé do Mato Dentro, Santana do Rio Preto, APA do Parque Nacional da Serra do Cipó, 19-24'52"S, 43-25'53"W, M.F. Santos \& E.G. Martins 175, 25.VIII.2007, fl. (SPF).

Material adicional: Espírito Santo: Cariacica, Res. Biológica Duas Bocas, 2027'29"S, 4031'10"W, A.M.A. Amorim et al. 7015, 15.II.2008, fr. (K, RB); idem, J.M.L. Gomes \& Laudicea 2747, 16.VI.1999, fl., fr. (K, VIES). Minas Gerais: Juiz de Fora, Res. Biológica Poço D'Anta, F.R. Salimena et al. s.n. [CESJ 20623], 17.V.1985, fl. (CESJ, K). São Paulo: Ubatuba, Estrada da Farinha, $9 \mathrm{~km}$ da Rod. Rio-Santos, R.C. Forzza \& A.M.A. Amorim 1529, 6.V.2000, fl. (K, SPF).

Espécie de fácil reconhecimento pelo hipanto muito desenvolvido, de colorido vináceo chamativo, contrastando com a corola amarela, é endêmica da Mata Atlântica nos estados do Sudeste e Sul do país (Barbosa et al. 2014). Na Serra do Cipó, P. nuda foi coletada apenas uma vez na região leste, em mata ciliar, com flores em agosto. 
Flora da Serra do Cipó, Minas Gerais: Rubiaceae

28.9. Psychotria pleiocephala Müll. Arg., Flora 59: 549, 552. 1876.

Fig. 9. B, O.

Arbustos ou arvoretas glabros, eretos ou escandentes, 1-6 m alt.; ramos evidentemente quadrangulares, alados, carnosos na planta viva, estreitados abaixo dos nós. Estípulas bífidas, persistentes, (5-)6-8 x 4-6 mm, lâmina ausente, lobos triangulares, agudos, subpatentes. Folhas opostas, pecioladas; pecíolo 0,7-1,2 cm compr.; lâmina oblonga a oboval, base aguda a decorrente, margem plana, ápice obtuso a acutiúsculo, (5-)7-13(-15) cm compr., (2-)3-4(-4,5) cm larg. (o par de folhas subtendendo a inflorescência muitas vezes menor), cartáceas, discolor, face abaxial secando verde a castanho-olivácea a avermelhada, face adaxial secando verde a castanho-esverdeada, glabra, nervura mediana esparsamente pilosa; venação eucamptódroma, nervuras salientes em ambas as faces, secundárias (9-)10-12 pares, arqueadas, nervuras intersecundárias e retículo salientes. Inflorescências terminais em cimeiras densas, arredondadas, multifloras, pedunculadas; pedúnculo quadrangular $1,5-2,5 \mathrm{~cm}$ compr., com ramos de 2-3 ordens; brácteas 3-4 mm compr., ovais, verdes a arroxeadas, nas ramificações da inflorescência e subtendendo címulas e botões; hipanto $2 \mathrm{~mm}$ compr., ca. 1,5 mm larg., tubo $1 \mathrm{~mm}$ compr., apicalmente truncado; corola creme, 6-7 mm compr., ca. $6 \mathrm{~mm}$ larg., lobos patentes a reflexos, corniculados; estames longamente exsertos nas flores brevistilas. Drupas ovoides, coroadas pelos restos do cálice, sulcadas quando secas, azuis quando maduras, 4-5 mm compr., 2-3 mm diâm.

Material examinado: Congonhas do Norte, Serra Talhada, Faz. Vereda do cambota, alto da Serra do João Camilo, 1848'39"S, 4345'09"W, R. Riina et al. 1330, 19.I.2004, fl. (K, SPF); $9 \mathrm{~km} \mathrm{~S}$ de Congonhas do Norte, 1855'48"S, 4340'17"W, M.F. Calió et al. 183, 20.I.2007, fl. (SPF). Itambé do Mato Dentro, Santana do Rio Preto, APA do Parque Nacional da Serra do Cipó, 19²3'46,9"S, 43ํㄴ'07,4"W, M.F. Santos \& J.B.C. Marques 458, 23.X.2008, fl. (SPF).

Material adicional: Minas Gerais: Juiz de Fora, Morro do Imperador, D.S. Pífano \& A.S.M. Valente 262, 11.I.2002, fl. (CESJ, K); Faz. de Christioma, Y. Mexia 5469, 30.XII.1930, fl. (F, K); Serra do Ouro Branco, Riedel 2875, fl. (K, isótipo); idem, C. Reis s.n. SPF 122444, 14.V.1988, fr. (SPF); idem, L.R. Lima et al. 377, 10.III.2005, fl. (SPF); s.l., Claussen s.n., coll. 1840, fl. (K); s.I., Glaziou 14918, V.1885, fl. (K).

Psychotria pleiocephala é uma espécie endêmica da Mata Atlântica de planalto, fácil de identificar devido aos ramos quadrangulares. Ocorre a partir do interior do Rio de Janeiro e Espírito Santo, estendendo-se ao leste de Minas Gerais (Barbosa et al. 2014) e com limite oeste de ocorrência em Congonhas do Norte. Na Serra do Cipó, foi coletada em matas ciliares e capões na região nordeste e leste da serra, florescendo entre outubro e janeiro.
28.10. Psychotria cf. spathicalyx Müll.Arg. in Mart., Eichler \& Urb., FI. bras. 6(5): 310, tb. 50. 1881. Fig. 9. P.

Subarbusto ereto, $50 \mathrm{~cm}$ alt.; ramos delgados, cilíndricos, ligeiramente estreitados abaixo dos nós, glabros. Estípulas bífidas, persistentes, 3-4 × 3-5 mm, glabras, lâmina $1 \mathrm{~mm}$ compr., lobos largos, triangulares, acuminados. Folhas pecioladas; pecíolo 0,5-0,7 cm compr.; lâmina estreitamente lanceolada a estreitamente obovada, base decorrente, margem plana, ápice agudo a obtuso, 9-11 cm compr., 2-3 cm larg., subcartácea, discolor, face abaxial secando castanho-avermelhada, face adaxial secando castanho-escura, glabra; venação eucamptódroma, nervuras secundárias 9-11 pares, arqueadas, salientes na face abaxial, impressas na face adaxial, nervuras intersecundárias inconspícuas, retículo visível abaxialmente. Inflorescências terminais, em glomérulos sésseis, 1-4-floras; brácteas 10-13 compr., 11-12 mm larg., arredondadas, vermelhas; hipanto $8 \mathrm{~mm}$ compr., ca. 1,5 mm larg., aparentemente fendido até a base, lobos irregulares, apicalmente denteados; corola $11 \mathrm{~mm}$ compr., ca. $5 \mathrm{~mm}$ larg., lobos reflexos; estames subinclusos; estigma bífido. Drupas não observadas.

Material examinado: Santana do Riacho, Serra do Cipó, km 152, Mello Barreto 8839, 7.II.1938, fl. (BHCB ex $\mathrm{BHMH}$,

Material adicional: Minas Gerais: Lima Duarte, Parque Estadual da Serra do Ibitipoca, 21\%42,11'S, 4353,06"W, R.C. Forzza et al. 3166, 10.III.2004, fl. (RB, SPF); Santa Bárbara, Serra do Caraça, caminho a Capelinha, SW de Catas Altas, ca. $20^{\circ} 05^{\prime}$ S, 4327'W, M.M. Arbo et al. 5280, 18.II.1991, fl. (SPF).

O único registro deste táxon na área foi identificado erroneamente pelo próprio P.C. Standley (F) como Cephaelis spathacea (Müll. Arg.) Standl., provavelmente referindo-se a Cephaelis spathicalyx (Müll.Arg.) Standl. (= Psychotria spathicalyx Müll. Arg.). $\mathrm{O}$ espécime apresenta brácteas vermelhas arredondadas, diferindo de Psychotria hastisepala Müll. Arg., a única outra espécie ocorrente no Sudeste do Brasil que apresenta glomérulos bracteados sésseis, porém com brácteas esverdeadas a paleáceas, truncadas. Infelizmente não foi possível estudar em detalhe o material, e a descrição foi complementada a partir da descrição de Müller Argoviensis (1881: 319, tab. 50, fig. 2) na Flora Brasiliensis. Coletada apenas uma vez na Serra do Cipó, com inflorescências jovens em fevereiro.

28.11. Psychotria stachyoides Benth., Linnaea $23: 464.1850$.

Fig. 9. Q.

Subarbustos ou arbustos, eretos ou semiescandentes, 0,4-2 m alt.; ramos delgados, cilíndricos, estreitados abaixo dos nós, tomentosos quando 
jovens. Estípulas bífidas, persistentes, (6-)8-12 x 3 $\mathrm{mm}$, hirsutas a glabrescentes, lâmina (2-)4-5 mm compr., lobos estreitos, acuminados. Folhas opostas, pecioladas; pecíolo 0,5-1 cm compr.; lâmina estreitamente lanceolada a estreitamente elíptica, base aguda a decorrente, margem plana, ápice agudo a levemente acuminado, (3-)4-9(-10) cm compr., (1)1,5-2,5(-3) cm larg., membranácea, discolor, face abaxial secando verde a castanho-olivácea, face adaxial secando verde a castanho, densamente tomentosa passando a glabrescente; venação eucamptódroma, nervuras salientes na face abaxial, impressas na face adaxial, nervuras secundárias (6-)79 pares, oblíquas, nervuras intersecundárias inconspícuas, retículo saliente abaxialmente. Inflorescências terminais em tirsos estreitos, congestos, abrangendo um ou dois nós a partir do ápice do ramo, ramificadas em 2-4 ordens acima do pedúnculo; pedúnculo $1-2 \mathrm{~cm}$ compr.; brácteas 4-10 $\mathrm{mm}$ compr., estreitamente triangulares, agudas, verdes a arroxeadas; hipanto $5 \mathrm{~mm}$ compr., ca. 1,5 $\mathrm{mm}$ larg., tubo $2 \mathrm{~mm}$ compr., lobos irregulares, subulados; corola creme, 6-7 mm compr., ca. $3 \mathrm{~mm}$ larg., lobos patentes a reflexos, com anel de tricomas internamente; estames subinclusos; estilete glabro, estigma bífido. Drupas ovoides, coroadas pelos restos do cálice, sulcadas quando secas, lilases a azuladas quando maduras, 4-4,5 mm compr., 2-2,5 mm diâm.

Material examinado: Santana do Riacho, Serra do Cipó, rodovia Belo Horizonte - Conceição do Mato Dentro, km 135, 1913'S, 4330'W, R. Mello-Silva et al. CFSC 10366, 22.VII.1987, fl. (SPF); idem, R.M. Harley et al. CFCR 5990, 14.XI.1984, fl. (K, SPF); Rodovia MG 010, km 117, BH Conceição do Mato Dentro, P.T Sano et al. 518, 20.X.1997, fl., fr. (SPF); a $400 \mathrm{~m}$ da bifurcação para Morro do Pilar, a W da rodovia, M.T.V. Campos \& E.D.P. Souza CFSC 13562, 21.XI.1993, fl. (SPF); idem, M.T.V. Campos \& E.D.P. Souza CFSC 13378, 21.IX.1993, fl. (SPF); RPPN Brumas do Espinhaço e Ermo do Gerais, C.A. Ferreira Junior 969, 28.XI.2012, fl. (BHZB, SPF); idem, M.G.C.Fernandes et al. 1730, 27.XI.2012, fl. (BHZB, SPF).

Material adicional: Bahia: Abaíra, Campo de Ouro Fino, 1315'S, 4154'W, B. Stannard et al. H50817, 25.I.1992, fr. (CEPEC, HUEFS, K, SPF). Minas Gerais: $27 \mathrm{~km}$ SW of Diamantina on road to Gouveia, H.S. Irwin et al. 22130, 17.I.1969, fr. (K, NY, UB); Lima Duarte, Parque Estadual do Ibitipoca, 2122'S, 4353'W, C.B. Costa \& G.Y. Kawauchi 286, 13.V.2000, fr. (K, SP).

Psychotria stachyoides ocorre na Mata Atlântica do leste do Brasil (Espírito Santo, Rio de Janeiro, São Paulo, Paraná e Santa Catarina), estende-se pelas matas ciliares até os campos rupestres dos estados de Bahia e Minas Gerais (Barbosa et al. 2014). É uma espécie bastante variável com respeito à pilosidade, sendo que as populações da Serra do Cipó exibem indumento denso, ao passo que em outras localidades os espécimes apresentam-se ligeiramente pilosos a glabrescentes. A aparência das inflorescências varia dependendo da fase de floração, sendo que as brácteas, no início da estação florífera, apresentam-se mais largas e encobrem as inflorescências, e na fase frutífera as brácteas externas caem e expõem os frutos. Na Serra do Cipó, esta espécie ocorre em matas ciliares e capões de mata, e foi coletada com flores em julho, setembro e novembro.

28.12. Psychotria subtriflora Müll.Arg., Flora 59: 553. 1876.

Cephaelis bradei Standl., Publ. Field Mus. Nat. Hist., Bot. Ser. 22: 173. 1940. Typus: Santa Luzia, Serra do Cipó, km 134, Brade 1255, 15.IV.1935 (F, $\mathrm{RB}$ !), syn. nov.

Fig. 9. R.

Arbustos glabros, $2 \mathrm{~m}$ alt.; ramos cilíndricos, levemente estriados. Estípulas bipartidas a partir da base, lâmina inconspícua, 1-2 x 1-2,5 mm, lobos triangulares, obtusos, $1 \mathrm{~mm}$ compr. Folhas opostas, subsésseis a pecioladas; pecíolo 1-6 mm compr.; lâmina estreitamente lanceolada, base decorrente, margem plana a ligeiramente revoluta, ápice obtusiúsculo, 3-8 cm compr., 0,5-1,8 cm larg., cartácea, levemente discolor; venação eucamptódroma, nervuras secundárias (7-)9-11 pares, oblíquas, espaçadas, pouco evidentes, retículo pouco evidente. Inflorescências terminais, em glomérulos sésseis, 1-4-floras, envolvidas por 2-3 brácteas estreitamente triangulares, $5 \mathrm{~mm}$ compr., verdes a escariosas; flores 5-meras, sésseis; hipanto tubuloso, verde, tubo $1 \mathrm{~mm}$ compr., lobos subulados, ca. $1 \mathrm{~mm}$ compr., ca. 0,5 mm larg.; corola alva a creme, 8-9 mm compr., 6-7 mm larg., glabra, infundibuliforme, lobos reflexos; estames inseridos na porção superior do tubo, anteras exsertas nas flores brevistilas. Drupas obovoides, coroadas pelos restos do cálice, levemente sulcadas quando secas, azuis a arroxeadas quando maduras, 4-6 mm compr., 3,5-5 mm diâm.

Material examinado: Santana do Riacho, Serra do Cipó, km 107, caminho para a Usina Dr Pacífico Mascarenhas, E. Forero et al. CFSC 8999, 7.IX.1980, fr. (SP, SPF); rodovia Belo Horizonte - Conceição do Mato Dentro, km 125, J.R Pirani et al. CFSC 12824, 7.XII.1991, fl. (SPF). Santa Luzia [Santana do Riacho], km 134, Mello Barreto 8891, 8920, 4.II.1938, fl. (BHCB).

Material adicional: Bahia: Rio de Contas, Pico das Almas, 1332'S, 4155'W, R.M. Harley et al. 27153, fr. (CEPEC, K, SPF). Goiás: Alto Paraíso de Goiás, 140ํ'48"S, 47ํ3'35"W, E. Chaves \& V. Mendes 63, 23.X.2004, fr. (K, UB).

Com distribuição associada à Mata Atlântica (Rio de Janeiro e São Paulo), esta espécie também ocorre em florestas ciliares do Brasil central no estado de Goiás, Minas Gerais e Bahia (Barbosa et al. 2014). Todas as populações de $P$. subtriflora da Serra do Cipó apresentam folhas estreitamente lanceoladas não atingindo $2 \mathrm{~cm}$ de largura, enquanto em outras localidades as folhas podem ultrapassar essa dimensão (Chaves \& Mendes 63, Goiás). Crescendo em capões de mata, na Serra do Cipó, esta espécie foi coletada com flores em fevereiro e abril, frutificando em setembro. 
Flora da Serra do Cipó, Minas Gerais: Rubiaceae

28.13. Psychotria vellosiana Benth., Linnaea 23: 464. 1850.

Fig. 9. S.

Arbustos 1-2,5 m alt.; ramos cilíndricos, lisos, glabros. Estípulas bipartidas, lâmina 4-6 x 3-5 mm, lobos estreitos, longamente acuminados, 4-8 $\mathrm{mm}$ compr. Folhas pecioladas; pecíolo 1-3 mm compr.; lâmina largamente lanceolada a oval, base atenuada a arredondada, margem plana, ápice longamente acuminado, (4-)5-8 cm compr., 2-3,5 cm larg., cartácea, levemente discolor, secando esverdeada, glabra a pilosa, com tricomas concentrados sobre as nervuras; venação broquidódroma, nervuras secundárias paralelas às intersecundárias e indistinguíveis destas, aproximadas, (15-)17-20 pares, salientes em ambas as faces, retículo evidente próximo à margem, nervura coletora conspícua. Inflorescências axilares e subterminais, em glomérulos sésseis a brevemente pedunculados, pedúnculo 1-12 mm compr., 5-9-floras, subtendidas por 2-6 brácteas triangulares de até $6 \mathrm{~mm}$ compr., verdes; flores sésseis; hipanto turbinado, tubo ausente, lobos subulados, ca. 1 mm compr., estreitos; corola alva, 8-10 mm compr., 5-6 $\mathrm{mm}$ larg., glabra, infundibuliforme, lobos reflexos; anteras exsertas nas flores brevistilas. Drupas ovoides, restos do cálice pouco salientes, levemente sulcadas quando secas, atropurpúreas e brilhantes quando maduras, 5-6 mm compr., 3,5-4,5 mm diâm.

Material examinado: Congonhas do Norte, Serra Talhada (Serra do Cipó), $9 \mathrm{~km} \mathrm{~S}$ de Congonhas do Norte na estrada para Conceição do Mato Dentro, entrada para Extrema seguindo $11 \mathrm{~km}$, Fazenda Imbaúbas (propriedade do Sr. Helvécio Lacerda de Queiroz), 1855'78"S, 4340'42"W, J.R. Pirani et al. 5741, 3.II.2009, fr. (CTES, K, SPF). Jaboticatubas, J. Semir \& D.A. Lima CFSC 4848, 15.XII.1973, fl. (SP); rodovia Lagoa Santa-Conceição do Mato Dentro-Diamantina, M.G.L. Wanderley 508, 3.XI.1978, fl. (SP, SPF); idem, km 123-4, N.L. Menezes CFSC 4565, 19.X.1973, fl., fr. (SP, UEC); idem, km 126, J. Semir \& M. Sazima CFSC 4948, 10.II.1974, fr. (SP); idem, km 127, J. Semir \& M. Sazima CFSC 5026, 7.VII.1974, fl., fr. (UEC); idem, km 136, M.S.F. Silvestre 9069, XI.1978, fl., fr. (UEC). Santana do Riacho, Serra do Cipó, $3 \mathrm{~km}$ da portaria Alto do Palácio, Canelas de Ema gigantes, $M$. Pereira \& $M$. Lucca 909, 12.X.1992, fl. (BHCB, SPF); idem, M. Pereira \& M. Lucca 911, 16.VIII.1992, fl. (BHCB); Alto do Palácio, R. SimãoBianchini \& S. Bianchini CFSC 12788, 2.VI.1991, fr. (SPF); Parque Nacional da Serra do Cipó, $\mathrm{N}$ da base do IBAMA, M.T.V.A. Campos \& J.R. Pirani CFSC 13043, 1.V.1993, fr. (SPF); idem, R. Mello-Silva \& J.R. Pirani CFSC 11325 , 24.III.1989, fr. (SPF); idem, km 115 ao longo da rodovia Belo Horizonte - Conceição do Mato Dentro, Alto do Palácio, $A$. Furlan et al. CFSC 7486, 5.X.1981, fl. (SPF); idem, km 120, G.L. Esteves et al. CFSC 5963, 14.XI.1984, fl. (SPF); idem, km 124, A. Furlan et al. CFSC 6650, 13.X.1980, fl. (SP, SPF); idem, M.T.V.A. Campos \& J.R. Pirani CFSC 13096, 2.V.1993, fr. (SPF); idem, km 128, J.R. Pirani et al. CFSC 9770, 3.V.1986, fr. (SPF); Morro do Pilar, estrada MG-010 cerca de $1,5 \mathrm{~km}$ antes da bifurcação entre Morro do Pilar e Conceição do Mato Dentro, M.T.V.A. Campos \& N. Roque CFSC 13303, 7.VIII.1993, fl. (SPF); idem, M.T.V.A. Campos \& E.D.P. de Souza CFSC 13488, 26.X.1993, fl. (SP, SPF); idem, M.T.V.A. Campos \& J.M. Arcanjo CFSC 13810, 28.IX.1994, fl. (SPF); $1400 \mathrm{~m}$ antes da bifurcação entre Morro do Pilar e Conceição do Mato Dentro, M.T.V.A. Campos \& J.P.M. Garcia CFSC
13636, 29.I.1994, fr. (SPF); ; cerca de $400 \mathrm{~m}$ antes da bifurcação entre Morro do Pilar e Conceição do Mato Dentro, M.T.V.A. Campos \& N. Roque CFSC 13313, 8.VIII.1993, fr. (SPF); idem, M.T.V.A. Campos \& J.M. Arcanjo CFSC 13686, 28.III.1994, fr. (SP, SPF); ; $12 \mathrm{~km} \mathrm{NE}$ de Cardeal Mota para Conceição do Mato Dentro, 1920'S, 433'W, M.M. Arbo et al. 4765, estéril (SPF).

Material adicional: Bahia: Lençois, Serra Larga, J.R. Pirani et al. CFCR 7188, 19.XII.1984, fl. (K, SPF). Minas Gerais: Caeté, Serra da Piedade, 2040'S, 4340'W, J.R. Pirani et al. CFCR 11176, 23.VII.1987, fr. (K, SPF).

Distribuída amplamente na América do Sul, desde a Venezuela até o Paraguai, é frequente na Mata Atlântica desde o Pernambuco até Santa Catarina, com registros no interior do país nos estados de Goiás, Distrito Federal e Minas Gerais (Barbosa et al. 2014). Psychotria vellosiana apresenta ampla variabilidade morfológica, portando folhas glabras a densamente velutinas, estreitamente lanceoladas até largas e ovais, inflorescência séssil a subséssil até pedunculada. A dificuldade de circunscrição taxonômica nesta espécie é refletida pela sua ampla sinonímia (Delprete et al. 2005, Taylor 2007). Para fins de florística local, a descrição apresentada aqui baseia-se em formas montanas desta espécie, coletadas nos campos rupestres de Bahia e Minas Gerais, que geralmente apresentam hábito mais compacto, distalmente muito ramificado, inflorescências subsésseis a curtamente pedunculadas, folhas glabras e largamente lanceoladas a ovais, longamente acuminadas. $\mathrm{Na}$ Serra do Cipó, esta espécie foi coletada entre rochas, florescendo entre julho e dezembro.

28.14. Psychotria warmingii Müll. Arg., Flora 59: 546. 1876.

Fig. 9. T.

Arbustos ou subarbustos totalmente glabros, até $0,5 \mathrm{~m}$ alt.; ramos delgados, cilíndricos. Estípulas bífidas, persistentes, $1 \times 0,8-1 \mathrm{~mm}$. Folhas sésseis a curtamente pecioladas; pecíolo até $1 \mathrm{~mm}$ compr.; lâmina oval, base arredondada a subcordada, margem plana a ligeiramente espessada, ápice longamente acuminado, às vezes assimétrico, (4-)4,5-6 cm compr., (1,5-)2-3 cm larg., membranácea, concolor, secando verde-olivácea clara, glabra; venação pinada, nervuras secundárias 5-6(-7) pares, aproximadas na base da folha, distanciadas e arqueadas em direção ao ápice, salientes em ambas as faces, retículo visível. Inflorescências dicasiais, subcorimbosas, arredondadas, ramificada em 3 ordens acima do pedúnculo; pedúnculo (1-)2,5-3 cm compr., delicado, provavelmente subereto a pêndulo; brácteas $0,5 \mathrm{~mm}$ compr., agudas; hipanto 1 $\mathrm{mm}$ compr., ca. 0,6 mm larg., tubo $1 / 3$ do comprimento do hipanto, lobos irregulares, suberetos; corola creme, 4-5 mm compr., ca. $3 \mathrm{~mm}$ larg., lobos suberetos; estames subinclusos; estigma bífido. Drupas globosas a bilobadas, restos do cálice proeminentes, lisas a levemente rugosas quando secas, alvas quando maduras, 3-5 mm compr., 3,5-5,5 mm diâm. 
Material examinado: Lagoa Santa/Matozinhos, Cauê, APA Carste de Lagoa Santa, Brina \& Costa s.n., 19.XII.1995, fl. (MO, SPF 125192, BHCB 36509); Conceição do Mato Dentro, Brumado, G. Hatschbach 52825, 18.V.1989, fr. (MBM).

Material adicional: Espírito Santo: Santa Leopoldina, Colina Verde, 2005'51"S, 4026'16"W, L.F.S. Magnago et al. 976, 16.V.2006, fl. (MBML, K). Minas Gerais: Lagoa Santa, Warming s.n., fl. (K000174309, isótipo, G); São Gonçalo do Rio abaixo, Est. Ambiental de Peti - CEMIG, J.A. Lombardi et al. 4672, 23.IV.2002, fr. (BHCB, K); Jaboticatubas, Lagoa de D. Ignácia, Mello Barreto 10545, 6.I.1940 (BHCB, HUEFS); Serra do Espinhaço at Lapinha, ca. $18 \mathrm{~km} \mathrm{~N}$ of Serro on road (MG 2) to Diamantina, 1200m, H.S. Irwin 20730, 23.II.1968, fl. (MO, NY, RB, UNB); Santa Bárbara do Mato Dentro, Fazenda da Floresta, F.C. Hoehne s.n., 21.I.1921, fl. (SP); Itabira, G.M. Magalhães 2850, s.d., fl. (BHCB); Diamantina, 9 km S da cidade na estrada para extração, L.P. Queiroz 7613, 11.I.2003, fl. (HUEFS).

Psychotria warmingii ocorre em matas de planalto nos estados de Minas Gerais, São Paulo, Espírito Santo, Goiás, Distrito Federal, Bahia e Pernambuco (Barbosa et al. 2014). Sua ocorrência na Serra do Cipó é muito provável, tendo sido coletada em áreas próximas durante o mês de maio. A cor dos frutos desta espécie era desconhecida (Taylor 2007), sendo registrada como branca pela primeira vez neste trabalho.

\section{Psyllocarpus Mart. \& Zucc.}

Ervas ou subarbustos de pequeno porte; ramos tetragonais. Estípulas interpeciolares formando bainha, multilobadas, conspícuas apenas nas porções mais jovens da planta. Folhas opostas, com ou sem fascículos axilares de folhas menores, sésseis, glabras a pubérulas. Inflorescências terminais multifloras, capitadas ou racemos ou verticilastros ou flores solitárias. Flores bissexuadas, actinomorfas, 4-meras, curto-pediceladas ou sésseis; hipanto glabro, lacínios 2 ou 4, com pequenos lobos adicionais na margem superior do cálice entre os lobos principais, glabros ou pubérulos nas margens; corola com prefloração valvar, infundibuliforme, alva a azul-arroxeada, glabra externamente; estames 4, inseridos próximo da base do tubo da corola; anteras subsésseis, dorsifixas, introrsas; ovário bilocular, lóculos uniovulados, estilete curto, estigma levemente bilobado a capitado. Fruto cápsula septicida complanada, oval, coroada pelos restos do cálice, glabra; sementes orbicular-elípticas, complanadas, membranáceas, fracamente ou irregularmente aladas.

\section{Chave para as espécies}

1. Plantas ramificadas apenas na base, com entrenós recobertos pelas folhas 29.2. P. densifolius

1 1'. Plantas ramificadas acima da base, com entrenós evidentes.

2. Folhas sem fascículos de folhas menores nas axilas; flores solitárias

2 '. Folhas com fascículos de folhas menores nas axilas; inflorescências multifloras.

3. Inflorescências capitadas, corola alva 29.4. schwackei

3'. Inflorescências verticilastros, corola azul-arroxeada 29.1. P. asparagoides 29.3. P. laricoides

29.1. Psyllocarpus asparagoides Mart. ex Mart. \& Zucc., Flora 7 (supl. 4): 131. 1824.

Fig. 8. G.

Subarbusto ou erva perene, $30-40 \mathrm{~cm}$ alt.; ramos pubérulos a esparsamente pubérulos, entrenós 10-30 mm compr. Estípulas 6-8-lobadas, estreitamente triangulares, $0,2-0,75 \mathrm{~mm}$ compr., 0,1-0,2 $\mathrm{mm}$ larg.bainha 0,6-0,8 mm compr., 0,7-1,5 $\mathrm{mm}$ larg. Folhas com fascículos axilares de 4-12 pares de folhas menores; lâmina acicular a linear, base truncada, ápice acuminado, 9-27 mm compr., ca. 0,2 mm larg., membranácea, delicada, glabra a pubérula; nervuras inconspícuas. Inflorescência capitada, multiflora; flores pediceladas a curto-pediceladas; hipanto 2-lobado, hipanto 0,8-1,2 mm compr., 0,8-0,9 mm larg., lacínios triangulares a estreitamente triangulares, ápice agudo, margem pubérula, 1,2-1,5 mm compr., 0,5-0,9 mm larg.; corola alva, tubo 1-1,4 mm compr., 0,6-0,8 mm larg. na base, lobos largamente ovados a ovados, ápice agudo a arredondado, 0,6-1,3 $\mathrm{mm}$ compr., 0,6-1,2 mm larg.; filetes 0,1-0,2, anteras ca. $0,5 \mathrm{~mm}$ compr.; estilete 0,2-0,4 $\mathrm{mm}$ compr., estigma fracamente bilobado. Cápsula 3-3,5 mm compr., 2,5-3 mm diâm.

Material examinado: Santana de Pirapama, Serra do Cipó, Fazenda Toucan Cipó, estrada para captação, 190'18"S, 43ㄴ6'06"W, D.C. Zappi et al. 705, 15.II.2007, fl., fr. (ESA, K, SPF).

Material adicional: Minas Gerais: Botumirim, salida al S de la ciudad, 1652'S, 4301'W, R. Mello-Silva et al. 693, 19.XI.1992, fl., fr. (SPF); Diamantina, próximo ao antigo leito da estrada de ferro, próximo a Guinda, J.R. Pirani et al. CFCR 11773, 9.I.1988, fl., fr. (SPF); on road to Gouveia, H.S. Irwin et al. 21998, 15.I.1969, fl., fr. (K, UB); Grão-Mogol, vale do rio Itacambiruçu, 16036 'S, 425' W, J.R. Pirani et al. CFCR 12970, 14.VI.1990, fl., fr. (K, SPF); idem, M.T.V.A. Campos et al. CFCR 13277, 5.IX.1990, fl., fr. (K, SPF).

Psyllocarpus asparagoides ocorre na Bahia e Minas Gerais (Barbosa et al. 2014), em solo arenoso e entre rochas, nos campos rupestres. Diferencia-se das demais espécies que ocorrem na Serra da Cipó pelas inflorescências capitadas. Foi coletada na Serra do Cipó com flores e frutos em fevereiro. 
Flora da Serra do Cipó, Minas Gerais: Rubiaceae

29.2. Psyllocarpus densifolius Zappi \& Calió sp. nov. Typus: Minas Gerais, Santana do Pirapama, Serra do Cipó, acesso pela Faz. Inhame, Trilha da Senhorinha, 185' 36"S, 4345'30"W, D.C. Zappi, W. Milliken, D. Sasaki \& S.L. Edwards 1919, 9.III.2009, fl. (holótipo: $\mathrm{K}$; isótipos: MO, NY, RB, SPF).

Fig. 8. L-R.

Ab ceteris species Psyllocarpus ramis foliosis, basaliter fasciculatis, internodiis foliis brevioris, inflorescenta pauciflora bracteis hyalinis irregulariter fimbriatis subtenta differt.

Subarbusto 8-15(-20) cm alt., com sistema subterrâneo desenvolvido, densamente ramificado a partir da base; ramos simples ou pouco ramificados, glabros a diminutamente estrigosos, entrenós 3-5(-8) $\mathrm{mm}$ compr. (os distais mais curtos). Estípulas conspícuas, triangulares, 1-lobadas, longamente acuminadas a aristadas, 1-2 mm compr., 0,1-0,2 mm larg., margens ciliadas. Folhas densamente dispostas e adpressas ao caule, cobrindo os entrenós, às vezes com fascículos axilares de folhas menores; lâmina linear, base truncada, margem plana, ápice agudo, cuspidado, levemente pungente, $5-8(-10) \mathrm{mm}$ compr., 0,8-1,1 mm larg., 6-10 vezes mais longa que larga, coriácea, espessa, diminutamente estrigosa a escabra nas margens; venação uninérvea, nervura secundárias inconspícuas. Inflorescências terminais, subtendidas por brácteas hialinas, irregularmente fimbriadas, com margens ciliadas, 1-2-floras, flores sésseis; hipanto 4lobado, hipanto 0,8-1,0 mm compr., 0,6-0,7 mm larg., lacínios aciculares, com a mesma forma e textura das folhas, 2,0-2,5 mm compr., 0,5-0,6 mm larg.; corola azul-clara a lilás com fauce amarela, tubo 1,8-2,0 mm compr., 0,7-0,9 mm larg. na base, lobos largamente ovados a ovados, ápice arredondado, 0,6-1,3 mm compr., 0,6-1,2 mm larg.; filetes 0,2-0,3, anteras ca. $0,5 \mathrm{~mm}$ compr.; estilete 2,2-2,4 $\mathrm{mm}$ compr., estigma fracamente bífido, lobos recurvos. Cápsula imatura 4 $\mathrm{mm}$ compr., 2,5 mm diâm.

Material examinado (parátipos): Santana de Pirapama, Serra do Cipó (Serra da Lapa), Distrito de São José da Cachoeira, Trilha da Senhorinha, 18.9422ㅇ, 43. 7498W, V.C. Souza et al. 32845, 19.II.2007, fl., fr. (ESA, K, RB); idem, 185'ㅇ"S, 4345'28"W, D.C. Zappi et al. 2748, 6.III.2010, fl., fr. (K, SPF, RB).

Psyllocarpus densifolius difere das demais espécies do gênero devido ao seu hábito, com ramos densos e pouco ramificados partindo de um sistema subterrâneo desenvolvido, sua folhagem muito mais densa do que a das outras espécies, e suas flores solitárias ou em fascículos 2-floros, subtendidas por uma série de brácteas hialinas irregulares. Sua distribuição é restrita aos campos rupestres da crista das serras, em solo arenoso com cascalho quartzítico, no setor noroeste da Serra do Cipó, no município de Santana de Pirapama, onde foi coletada com flores em novembro, fevereiro e março, e frutificando em março. Devido à sua distribuição restrita, e ao fato da única população conhecida não estar ainda incluída em uma área protegida, trata-se de uma espécie Vulnerável (2D), utilizando os critérios da IUCN (2001).

29.3. Psyllocarpus laricoides Mart. ex Mart. \& Zucc., Flora 7 (supl. 4): 131. 1824.

Fig. 8. H-J.

Subarbusto $12-100 \mathrm{~cm}$ alt:; ramos glabros, entrenós 0,5-3 cm compr. Estípulas 5-10-lobadas, estreitamente triangulares a lineares, 0,4-1,2 x 0,050,3 mm, bainha 0,6-0,8 mm compr., ca. $1 \mathrm{~mm}$ larg. Folhas com fascículos axilares de 6-14 pares de folhas menores; lâmina acicular, base truncada, ápice acuminado, 3-11 mm compr., 0,2-0,4 mm larg., membranácea, delicada, pubérulas a glabras próximo à base; nervuras inconspícuas.. Inflorescência verticilastro, multiflora; flores curto-pediceladas; hipanto 2-lobado, hipanto 0,8-2,1 mm compr., 0,8-1,3 $\mathrm{mm}$ larg., lacínios triangulares, ápice agudo, margem esparsamente estrigosa, 0,4-1,5 mm compr., 0,3-0,7 $\mathrm{mm}$ larg.; corola azul-arroxeada, às vezes alva, tubo 2,5-6 mm compr., 0,8-1 mm larg. na base, lobos ovados ou elípticos, ápice agudo a arredondado, 1,3-3 $\mathrm{mm}$ compr., 0,7-2,1 mm larg.; filetes ca. 0,3 $\mathrm{mm}$ compr., anteras 0,9-1,1 mm compr.; estilete 0,4-0,6 $\mathrm{mm}$ compr., estigma fracamente bilobado. Fruto 2,7-4 $\mathrm{mm}$ compr., 2-3 $\mathrm{mm}$ larg.

Material examinado: Congonhas do Norte, estrada para a Serra Talhada, ramo vicinal à esquerda da estrada para Gouveia, P. Fiaschi \& F.N. Costa 303, 17.VI.2000, fl., fr. (SPF); 6,8 km sudoeste da estrada Congonhas do Norte Gouveia, entrada a 3,7 km noroeste de Congonhas do Norte, estrada pelo alto da serra em local denominado localmente de Retiro dos Pereiras, 1851'40"S, 4344'60"W, J.R. Pirani et al. 5769, 4.Il.2009, fl., fr. (SPF); Fazenda Vereda do Cambota, alto da Serra do João Camilo, 184' 30 "S, 4345'09"W, R. Mello-Silva et al. 2377, 19.I.2004, fl., fr. (SPF); idem, 1848'39"S, 4348'39"W, J. Lovo et al. 13, 19.I.2004, fl., fr. (SPF); $9 \mathrm{~km} \mathrm{~S}$ de Congonhas do Norte na estrada para Conceição do Mato Dentro, entrada para Extrema, seguindo $11 \mathrm{~km}$ - Fazenda Imbaúbas (propriedade do Sr. Helvécio Lacerda de Queiroz), 185'48"S, 4340'17"W, M.F. Calió et al. 181, 20.I.2007, fl., fr. (SPF). Jaboticatubas, na proximidades da divisa do Parque, H.F. Leitão Filho et al. 27287, 27295 e 27363, 7.XII.1992, fl., fr. (UEC); planalto 5-6 km along road north from crossing of the stream "Ribeiro do Andrequicê" at Fazenda Palácio, G. Eiten \& L.T. 6707, 21.XI.1965, fl. (SP); rodovia Lagoa Santa Conceição do Mato Dentro - Diamantina, km 115, J. Semir \& M. Sazima CFSC 592, 15.XII.1971, fl., fr. (SP, UEC); idem, J. Semir et al. CFSC 4109, 29.IV.1973, fl. (SP); idem, km 126, J. Semir \& M. Sazima CFSC 1139, 5.III.1972, fl., fr. (SP, UEC); idem, M.G.L. Wanderley et al. 554, 15.V.1982, fl., fr. (SP); idem, km 127, J. Semir \& M. Sazima CFSC 511, 13.XII.1971, fl., fr. (SP, UEC); idem, J. Semir \& M. Sazima CFSC 735, 7.Il.1972, fl., fr. (SP, UEC); idem, J. Semir \& M. Sazima CFSC 2595, 19.VII.1972, fl. (SP); idem, J. Semir et al. CFSC 2766, 23.VII.1972, fl., fr. (SP, UEC); idem, km 128, A.B. Joly et al. CFSC 1094, 5.III.1972, fl. (SP); idem, A.B. Joly \& J. Semir CFSC 2947, 20.VIII.1972, fl. (SP); idem, A.B. Joly \& J. Semir CFSC 2989, 20.VIII.1972, fl., fr. (SP, UEC); idem, km 132, A.B. Joly \& J. Semir CFSC 3116, 21.VIII.1972, fl, fr. (SP); idem, A.B. Joly \& J. Semir CFSC 3148, 21.VIII.1972, fl., fr. (SP, UEC); idem, M. Sazima \& J Semir CFSC 3909, 16- 
24.Il.1973, fl. (SP); idem, M. Sazima \& J. Semir CFSC 3924, 1973, fl., fr. (SP, UEC); idem, J Semir \& M. Sazima CFSC 749, 8.II.1973, fl. (SP); idem, J. Semir \& M. Sazima CFSC 2036, 30.IV.1972, fl., fr. (SP, UEC); idem, J. Semir et al. CFSC 2349, 28.V.1972, fl., fr. (SP); idem, km 138-9, A.B. Joly et al. CFSC 2179, 27.V.1972, fl. (SP); idem, km 139, A.B. Joly et al. CFSC 1911, 17.IV.1972, fl fr. (SP, UEC); idem, J. Semir \& A.M. Joly CFSC 3784, 6.I.1973, fl., fr. (SP); idem, km 140, A.B. Joly et al. CFSC 1277, 6.III.1972, fl., fr. (SP); idem, A.B. Joly et al. CFSC 1292, 6.III.1972, fl. (SP); idem, km 142, M.S.F. Silvestre 9071, 2.XI.1978, fl., fr. (UEC); idem, A.B. Joly \& M. Sazima CFSC 3177, 22.VIII.1972, fl., fr. (SP); idem, A.B. Joly et al. CFSC 314, 8.Vl.1970, fl. (SP); idem, A.B. Joly et al. CFSC 230, 7.VI.1970, fl., fr. (SP); idem, A.B. Joly et al. CFSC 2100, 27.V.1972, fl., fr. (SP); idem, A.B. Joly et al. CFSC 2138, 27.V.1972, fl., fr. (SP, UEC); idem, A.M. Joly \& C. Müller CFSC 3471, 10.IX.1972, fl., fr. (SP); idem, J. Semir \& M. Sazima CFSC 2003, 30.IV.1972, fl., fr. (SP); idem, J. Semir \& M. Sazima CFSC 2728, 22.VII.1972, fl., fr. (SP, UEC); idem, J. Semir et al. CFSC 631, 6.II.1972, fl., fr. (SP). Santana de Pirapama, Serra do Cipó, Fazenda Inhame (Serra Mineira), 1855'S, 4354'W, I. Cordeiro et al. CFSC 8146, 23.III.1982, fl., fr. (SPF); Fazenda Toucan Cipó, estrada da captação, 1900'22"S, 4345'20"W, D.C. Zappi et al. 800, 16.II.2007, fl., fr. (ESA, K); Capela de São José, Estrada da Captação da Fazenda Toucan Cipó, 1900'19"S, 4345'27"W, D.C. Zappi et al. 2777, 10.III.2010, fl., fr. (K, SPF). Santana do Riacho, Serra do Cipó, F. Barros 340, 6.IX.1980, fl., fr. (SP); acesso pela Faz. Inhame, trilha do João Carrinho, 1902'55"S, 4344'14"W, D.C. Zappi et al. 1516, 25.II.2009, fl., fr. (K, SPF); Serra do Cipó (Serra da Lapa), estrada São José da Cachoeira-Santana do Riacho, trilha do João Carrinho, 19,0480 S, 43,7387 W, V.C. Souza et al. 32666, 18.Il.2007, fl., fr. (ESA, K); 7-12 km de Santana do Riacho, camino a Lapinha, ca. 1910'S, 4341'W, M.M. Arbo et al. 4838, 11.II.1991, fl., fr. (SPF); 1904'S, 4342'W, R.C. Forzza et al. 780, 5.III.1998, fl., fr. (SPF); Pico do Breu, 1910'S, 43ㄴ2'W, A.M.G.A. Tozzi \& L.S. Kinoshita 598, 23.XI.2000, fl., fr. (UEC); Alto do Palácio, T.B. Cavalcanti et al. CFSC 9884, 12.IX.1986, fl., fr. (SPF); idem, T.F. Daniel e N. Hensold 2280, 14.Il.1982, fl., fr. (SPF); próximo à sede do IBAMA do Alto do Palácio, J.R Pirani et al. CFSC 11922, 24.III.1991, fl., fr. (SPF); retiro do Alto do Palácio, $25 \mathrm{~km} \mathrm{NE}$ de Cardeal Mota, camino a Conceição do Mato Dentro, M.M. Arbo et al. 4265, 16.V.1990, fl., fr. (SPF); Parque Nacional da Serra do Cipó, ca. 190's, 43느'W, km 124 da Rodovia MG-010, M.F. Calió et al. 1, 8.VI.2002, fl., fr. (SPF); km 107, caminho para Usina Dr. Pacífico Mascarenhas, E. Forero et al. 8028 [CFSC 8941], 7.IX.1980, fl., fr. (SP, SPF); km 120-121 da estrada Lagoa Santa a Conceição do Mato Dentro, E. Forero et al. 7905 [CFSC 8818], 6.IX.1980, fl., fr. (SP, SPF); rodovia Belo Horizonte - Conceição do Mato Dentro, R. SimãoBiachini \& S. Bianchini CFSC 12796, 2.VI.1991, fl., fr. (SPF); idem, km 125, em frente à estátua do Velho Juca, J.R. Pirani et al CFSC 12689, 29.VII.1991, fl., fr. (SPF); idem, km 129, 1913'50"S, 4330'32,6"W, C.M. Siniscalchi et al. 25, 14.VI.2010, fl., fr. (SPF); idem, km 132, B. Stannard et al. CFCR 6019, 15.XI.1984, fl., fr. (SPF); idem, km 135, bifurcação da rodovia para Morro do Pilar, Parque Nacional da Serra do Cipó, M.C. Assis \& J.R. Pirani CFSC 11443, 20.V.1989, fl. (SPF); idem, km 138, Alto do Palácio, R.M. Harley et al. CFCR 6051, 15.XI.1984, fl., fr. (SPF); idem, km 139, C. Kameyama et al. CFSC 11497, 20.V.1989, fl., fr. (SPF); idem, km 140, A. Furlan \& M.G. Sajo CFSC 5964, 29.II.1980, fl., fr. (SP); idem, km 142, A.M. Giulietti et al. CFSC 9905, 11.X.1986, fl., fr. (SPF); Morro do Breu, ca. $31 \mathrm{~km}$ N of Chapéu de Sol, T.F. Daniel \& N. Hensold 2317, 17.II.1982, fl., fr. (SPF); RPPN Brumas do Espinhaço e Ermo do Gerais, J.
Ordones et al. 2075, 26.XI.2012, fl., fr. (BHZB, SPF).

Psyllocarpus laricoides ocorre na Cadeia do Espinhaço, na Bahia e em Minas Gerais (Barbosa et al. 2014), nos campos rupestres, sendo encontrada em solo arenoso e entre rochas. Diferencia-se das demais espécies que ocorrem na Serra da Cipó pelas flores dispostas em racemos. Foi coletada com flores e frutos praticamente ao longo do ano todo.

29.4. Psyllocarpus schwackei K. Schum., Bot. Jahrb. Syst. 25 (supl. 60): 18. 1898.

Fig. 8. K.

Erva perene ou subarbusto, $40-60 \mathrm{~cm}$ alt.; ramos glabros, entrenós 1,3-2,0 cm compr. Estípulas 3-5-lobadas, estreitamente triangulares, 0,15-0,8 $\mathrm{x}$ 0,15-0,25 mm, bainha 0,4-1 mm compr., 1-1,2 mm larg. Folhas raramente com 1-3 pares axilares de folhas menores, não organizadas em fascículos; lâmina acicular a linear, base truncada, ápice acuminado, 12-20 mm compr., 0,2-0,4 mm larg., membranácea, delicada, glabra; nervuras inconspícuas.. Flores solitárias, 2 por nó, raramente em racemo laxo, sésseis; hipanto 2-lobado, hipanto 11,25 $\mathrm{mm}$ compr., 0,8-1,1 $\mathrm{mm}$ larg., lacínios estreitamente triangulares, ápice agudo, margem esparsamente estrigosa, 1,1-1,75 mm compr., 0,5-0,55 $\mathrm{mm}$ larg.; corola azul-arroxeada, tubo corola 4-6 mm compr., 1,2-1,5 mm larg. na base, lobos da corola muito largamente ovados, ápice agudo a arredondado, 2-3 mm compr., 1,8-2 mm larg.; filetes 0,3-0,4 mm compr., anteras 1-1,1 mm compr.; estilete $0,4 \mathrm{~mm}$ compr., estigma capitado a fracamente bilobado. Cápsula 3-3,3 mm compr., 2,2-2,5 mm diâm.

Material examinado: Jaboticatubas, Serra do Cipó, rodovia Lagoa Santa - Conceição do Mato Dentro Diamantina, km 114, J. Semir \& J. Sazima CFSC 3400, 6.IX.1972, fl., fr. (SP); idem, km 116, A.B. Joly et al. CFSC 120, 6.VI.1970, fl. (SP). Santana do Riacho, Serra do Cipó, ca. $120 \mathrm{~km}$, ca. $145 \mathrm{~km} \mathrm{~N}$ of Belo Horizonte, H.S. Irwin et al. 19976,14.Il.1968, fl., fr. (SP); km 109 (antigo 114) da estrada Lagoa Santa a Conceição do Mato Dentro, E. Forero et al. 7714 [CFSC 8643], 6.IX.1980, fl., fr. (SP, SPF); rodovia Belo Horizonte - Conceição do Mato Dentro, km 110 (antigo 114), J.R. Pirani \& C. Kameyama CFSC 12918, 23.IV.1992, fl. (SPF); idem, km 114, S. Mayo et al. CFSC 7018, 28.II.1981, fl., fr. (SPF); idem, km 118, A.P. Duarte 9697, 22.III.1966, fl., fr. (HBR, K); idem, km 128, G. Eiten \& L. Eiten 6799, 23.XI.1965, fl., fr. (K, SP).

Material adicional: Minas Gerais: Grão-Mogol, I. Cordeiro \& J. Simonis CFCR 4124, 28.II.1983, fl., fr. (SPF).

Psyllocarpus schwackei ocorre na porção mineira da Cadeia do Espinhaço (Kirkbride 1979). Difere das demais espécies do gênero pelos ramos delgados e delicados, ausência de fascículos de pequenas folhas e flores frequentemente solitárias. Foi coletada com flores e frutos de fevereiro a abril e junho e setembro. 
Flora da Serra do Cipó, Minas Gerais: Rubiaceae

\section{Randia L.}

Arbustos ou árvores, às vezes lianas; ramos eretos, apoiantes ou semi-escandentes, geralmente armados. Estípulas interpeciolares, triangulares, com lâmina curta a ausente. Folhas opostas, concentradas na porção distal dos ramos. Flores unissexuadas (em plantas dioicas), sésseis a subsésseis, as masculinas em pequenas cimeiras, as femininas solitárias, 4-7meras, actinomorfas, alvas; hipanto turbinado a ovoide, laciniado; corola com prefloração contorcida, hipocrateriforme, creme, glabra ou pilosa; estames 47, inclusos, com filetes curtos; anteras lineares, dorsifixas; ovário bilocular, lóculos pluriovulados; estigma íntegro ou bilobado. Bagas globosas, ovoides ou elipsoides, geralmente bilocular, pericarpo coriáceo; sementes numerosas, discoides, dispostas horizontalmente, imersas em polpa gelatinosa.

1830.

30.1. Randia armata (Sw.) DC., Prodr. 4: 387.

Nome vulgar: limoeiro-do-mato.

Fig. 1. H-l.

Árvores ou arbustos trepadores, 3-4 m alt.; tronco avermelhado, ramos semi-apoiantes, aplanados, os laterais armados na extremidade distal com 2-4 acúleos agudos, ca. $1 \mathrm{~cm}$ compr., mais espessos nas partes velhas da planta, suberetos a patentes, râmulos tortuosos rebrotando a partir do nó dotado de acúleos. Estípulas triangulares, persistentes, escariosas, 4,5-6 x 2-3 mm. Folhas aproximadas na parte distal dos râmulos, subsésseis a curtamente pecioladas; pecíolo 0-10 mm compr.; lâmina elíptica a oboval, base cuneada a decorrente, margem plana, ápice obtuso a agudo, (3-)5-7 cm compr., (1,5-)2-3 cm larg., membranácea a cartácea, levemente discolor, tomentosa com tricomas concentrados sobre as nervuras na face abaxial, curtopilosa na face adaxial; venação broquidódroma, nervuras (7-)8-9 pares, oblíquas a ascendentes, salientes na face abaxial, impressas na face adaxial. Inflorescências terminais, flores masculinas: subsésseis em pequenas cimeiras de 2-3(-5) flores; pedicelo 5-10 mm compr.; hipanto 1,2 cm compr., tubo curto, lacínios estreitamente triangulares a lanceolados; corola alva, $3 \mathrm{~cm}$ compr., lobos obovados, subpatentes; estames $6 \mathrm{~mm}$ compr.; estigmas rudimentares; flores femininas: sésseis; hipanto 2-2,5 cm compr., tubo curto, lobos estreitamente triangulares; corola ca. $3 \mathrm{~cm}$ compr., lobos obovados, com estaminódios; estilete $4 \mathrm{~cm}$ compr., estigma bilobado. Bagas ovoides, pubescentes, c. 2-2,5 cm compr., ca. 1,2-2 cm larg., restos do cálice inicialmente coroando o fruto, decíduos na maturidade; pericarpo coriáceo, verde a amarelado.

Material examinado: Santana de Pirapama, Serra do Cipó, Fazenda Toucan Cipó, 1900'15,1"S, 43ํ46'34,42"W, W. Milliken et al. 4122, 19.XI.2009, fr. (SPF). Santana do
Riacho, rodovia Belo Horizonte - Conceição do Mato Dentro, Cardeal Mota, Morro da Pedreira, M.T.V.A. Campos et al. CFSC 12870, 7.I.1992, fr. (SPF); Morro da Pedreira, 1920'S, 4340'W, J.R. Pirani et al. 3709, 2.IV.1996, fr. (K, SPF); APA Morro da Pedreira, E.G.A. Martins et al. 94, 15.Il.2007, fr. (K, SPF); s.I., L. Krieger \& Urbano 10150, 19.II.1971, fr. (SPF). Material adicional: Minas Gerais: Santo Hipólito, $5 \mathrm{~km}$ na rodovia em direção a Monjolos, 1817'17"S, 4411'6"W, $R$. Mello-Silva 1530, 3.X.1997, fl. (K, SPF).

Randia armata tem ampla distribuição neotropical, ocorrendo desde o México até o Paraguai e a Argentina, em diversos tipos de vegetação, concentrando-se no Brasil na maioria dos estados do leste e também na Amazônia (Barbosa et al. 2014). Na Serra do Cipó, ocorre em matas ciliares, floresta seca semidecidual e capões de mata. Espécie esfingófila de floração rápida, não foi coletada em flor na área estudada, onde frutifica entre novembro e abril.

\section{Remijia DC.}

Árvores ou arbustos; ramos geralmente tetragonais, usualmente espessados, frequentemente pilosos. Estípulas interpeciolares 2-4, triangulares, grandes, frequentemente pilosas. Folhas decussadas ou verticiladas. Inflorescências panículas amplas, decussadas, subterminais a axilares, em grupos de 23 abaixo do par de folhas apicais; flores bissexuadas, actinomorfas, 5(6)-meras, heterostílicas, alvas ou rosadas; hipanto cupuliforme, 5(6)-denteado ou lobado; corola com prefloração valvar, hipocrateriforme, creme, amarelada ou rosada, glabra ou pilosa; estames 5(6), inclusos ou exsertos; anteras lineares com base sagitada, dorsifixas; ovário bilocular, lóculos pluriovulados; estigma íntegro ou bífido. Cápsula loculicida, coriácea, valvas bífidas no ápice; sementes numerosas, discoides a oblongas, irregularmente aladas.

31.1. Remijia ferruginea (A.St.-Hil.) DC., Prodr. 4: 357. 1825.

Fig. 2. L.

Arbusto 1-2 m alt.; ramos espessados, tetragonais, ferrugíneo-tomentosos. Estípulas triangulares, decíduas, 25-30 mm compr., $15 \mathrm{~mm}$ larg. Folhas decussadas ou 3(-4)-verticiladas, pecioladas; pecíolo 14-20 $\mathrm{mm}$ compr.; lâmina elíptica a lanceolada, base cuneada, margem revoluta, ápice agudo, 14-23 cm compr., 5-7,5 cm larg., corrugada, coriácea, discolor, densamente ferrugíneo-tomentosa a velutina na face abaxial, pilosa a glabrescente na face adaxial; venação broquidódroma, nervuras secundárias 13-18 pares, fortemente impressas na face adaxial, salientes na face abaxial. Inflorescências axilares a subterminais, 3-4-verticiladas, ultrapassando as folhas; flores pediceladas, subtendidas por brácteas naviculares; hipanto globoso, ca. $4 \mathrm{~mm}$ compr., tubo coroado por lobos subulados, ferrugíneo-tomentoso; corola 2,5-3 cm compr., ca. $2 \mathrm{~mm}$ larg., externamente 
rósea, ferrugíneo-tomentosa, internamente creme, lobos aproximadamente do mesmo comprimento que o tubo, reflexos, recurvados; estigma bífido. Cápsula oblonga, pubescente, 1,5-2 cm compr., ca. $1 \mathrm{~cm}$ larg.; sementes oblongas, 3,5-4,5 mm compr., com ala emarginada.

Material examinado: Congonhas do Norte, $13 \mathrm{~km} \mathrm{NW}$ de Congonhas do Norte, caminho a Gouveia, aprox. 18ㄴ1'S, 43ㄴ'W, M.M. Arbo et al. 5015, 13.II.1991, fl., fr. (SPF); estrada para Serra Talhada, ramo vicinal à esquerda da estrada para Gouveia, P. Fiaschi \& F.N. Costa 307, 17.VI.2000, fl., fr. (SPF); Serra Talhada, 11,4 km SW da estrada Congonhas do Norte - Gouveia, entrada ramificando a 3,7 km NE de Congonhas do Norte, estrada pelo alto da rumo ao vale do Rio Preto, 1815'19"S, 4344'55"W, J.R. serra denominada localmente como Serra do João Camilo, Pirani et al. 5181, 20.I.2004, fl. (K, MBM, SPF). Jaboticatubas, rodovia Lagoa Santa - Conceição do Mato Dentro - Diamantina, km 114, J. Semir et al. CFSC 4791, 10 a 15.XII.1973, fl. (SP, UEC); idem, km 122, A.B. Joly \& J. Semir CFSC 3265, 22.VIII.1972, fr. (SP); idem, km 124, J. Semir et al. CFSC 4171, 30.IV.1973, fl., fr. (SP); idem, km 127, A.B. Joly et al. CFSC 2425, 29.V.1972, fl., fr. (SP, UEC); idem, J.Semir \& A.B. Joly CFSC 3803, 7.I.1973, fl., fr. (SP). Santana de Pirapama, Serra do Cipó, Fazenda Toucan Cipó, estrada para a captação, 1900'22"S, 4345'20"W, D.C. Zappi et al. 803, 16.II.2007, fl., fr. (ESA, K); trecho de São José da Cachoeira - Inhame, subida da trilha da Senhorinha, 1900'22"S, 4345'20"W, V.C. Souza et al. 32742, 19.II.2007, fl., fr. (ESA, K); acesso pela Fazenda Inhame, 1900'30"S, 4375'40"W, W. Milliken et al. 4290, 19.III.2011, fl. (SPF); Fazenda Inhame, aproximadamente 185'S, 4354'W, $I$. Cordeiro et al. CFSC 8175, 23.III.1982, fl., fr. (SPF). Santana do Riacho, Cardeal Mota, APA Morro da Pedreira, 1920'S, 4340'W, E.A. Martins et al. 94, 15.II.2007, fr. (K, SPF); estrada da Usina, M.C. Henrique et al. CFSC 6867, 9.I.1981, fl. (SP, SPF); idem, J. Semir CFSC 5934, 19.XII.1979, fl. (SP); sede da Fazenda Monjolos, L.S. Kinoshita \& K. Yamamoto 02/192, 24-27.IX.2002, fr. (UEC); km 106, G.M.
Faria \& M. Mazucato 136, I.1990, fl. (SPF); rodovia Lagoa Santa - Conceição do Mato Dentro, km 109 (antigo 114), E. Forero et al. 7731, 6.IX.1980, fl. (SP); idem, km 117, A. Furlan et al. CFSC 7215, 19.IV.1981, fl. (SPF); Parque Nacional da Serra do Cipó, J.R. Pirani et al. CFSC 12235 , 25.III.1991, fl. (SPF); idem, M.T.V.A. Campos et al. CFSC 13053, 1.V.1993, fl., fr. (SPF).

Remijia ferruginea ocorre em Minas Gerais e São Paulo (Barbosa et al. 2014), em solos arenosos e entre rochas em áreas serrranas. Na Serra do Cipó, ocorre nos afloramentos rochosos acima de $800 \mathrm{~m}$ alt. Suas flores exalam aroma agradável, e seu período de floração ocorre de janeiro a fevereiro, tendo sido encontrada com frutos de fevereiro a setembro.

\section{Rudgea Salisb.}

Arbustos, arvoretas ou árvores. Estípulas interpeciolares fimbriadas ou com apêndice aristado ou espinescente, muito raramente inteiras, usualmente decíduas, glabras ou pubescentes. Folhas opostas, glabras ou pubescentes. Inflorescênias terminais, sésseis a pedunculadas, dicasiais a capitadas, muito raramente acompanhadas de brácteas involucrais; flores bissexuadas, actinomorfas, heterostílicas, de tamanho mediano, 5(-6)-meras, alvas a cremeesverdeadas; lacínios partidos ou formando tubo, glabros ou pubescentes; corola com prefloração valvar, hipocrateriforme, base estreita, glabra ou internamente pubescente; estames 5, inseridos na região da fauce da corola; ovário bicarpelar, lóculos uniovulados. Fruto drupa, com 2 pirênios; sementes com face ventral sulcada.

Chave para as espécies

1. Folhas amplamente obovais a elípticas ou oblanceoladas, densamente tomentoss abaxialmente e com retículo muito evid

1'. Folhas estreitamente lanceoladas, glabras ou pilosas abaxialmente, retículo inconspícuo a pouco

evidente.

2. Estípulas com apêndices subapicais esparsamente denteados

2'. Estípulas com apêndices apicais 7-10-fimbriados

32.1. R. nodosa

32.2. R. sessilis

\subsection{Rudgea nodosa (Cham.) Benth., Linnaea} 23: 45-457. 1850.

Subarbustos ou arbustos, 0,5-1 m alt., glabros ou pilosos; ramos castanho-claros, levemente comprimidos, entrenós superiores $2-4 \mathrm{~cm}$ compr., nós espessados. Estípulas 10-12 x 5-6 mm com apêndice subapical esparsamente denteado. Folhas pecioladas; pecíolo 4-8 mm compr.; lâmina elíptica a obovada, base atenuada a cuneada, margem ligeiramente revoluta, ápice obtuso a curtamente acuminado, (6-)910(-11) cm compr., 1,5-3 cm larg., cartácea, glabra ou pilosa na face inferior; venação broquidódroma, nervuras secundárias e retículo inconspícuos a pouco conspícuos em ambas as faces, domácias pouco profundas, com tricomas na abertura. Inflorescência terminal, curtamente pedunculada, em cimeira congesta, 6-12-flora; flores sésseis; hipanto turbinado, lacínios largamente triangulares, ciliados; corola alva, carnosa, 10-15 mm compr., tubo infundibuliforme, externamente glabro, internamente piloso, lobos patentes na antese; anteras exsertas na flor brevistila, inclusas na flor longistila.

Drupa ovoide, 8-11 mm compr., lisa, verdeescura (provavelmente imatura); sementes hemisféricas, 6-7 mm compr., castanho-claras.

Material examinado: Santana do Riacho, Serra do Cipó, RPPN Brumas do Espinhaço e Ermo do Gerais, C.A. Ferreira Jr 794, 28.XI.2012, fl. (BHZB, SPF).

Material adicional: Minas Gerais, Santa Bárbara, 
Flora da Serra do Cipó, Minas Gerais: Rubiaceae

Serra do Caraça, R. Mello-Silva et al. 1340, 22.V.1997, fr. (SPF, SPFR). Rio de Janeiro, Parque Nacional do Itatiaia, J.M.S. Braga 2901, 16.X.1995, fl. (RB, SPF).

Rudgea nodosa ocorre nos estados de São Paulo, Rio de Janeiro, Espírito Santo, Bahia e Minas Gerais (Zappi 2003). Na Serra do Cipó, foi coletada uma única vez, com flores em novembro, em floresta nebular. Os materiais originários da Cadeia do Espinhaço de Minas Gerais eram conhecidos como Rudgea hypomalaca Standl., mas esse nome foi sinonimizado por Zappi (2003) sob R. nodosa (Cham.) Benth. O presente material não apresenta estípulas basais alargadas encontradas comumente em $R$. nodosa, e estudos moleculares estão sendo realizados no momento para esclarecer as relações entre as espécies do gênero (Bruniera \& Zappi em prep.).

32.2. Rudgea sessilis (Vell.) Müll.Arg. subsp. cipoana (Standl.) Zappi, Kew Bull. 58(3): 538. 2003.

Fig. 6. K.

Subarbustos ou arbustos, (0,5-)1-3 m alt., quase totalmente glabros; ramos castanhoacinzentados, levemente comprimidos, entrenós superiores 1-4 cm compr., nós espessados. Estípulas 5-12 x 4-5 mm com apêndice apical 7-10-aristado. Folhas pecioladas; pecíolo 1-9 mm compr.; lâmina estreitamente lanceolada, base atenuada a truncada, margem revoluta, ápice agudo a acuminado, (2-)3-8(10) $\mathrm{cm}$ compr., $(0,8-) 1-2,5 \mathrm{~cm}$ larg., firmemente cartácea, glabra; venação broquidódroma, nervuras secundárias e retículo inconspícuos a pouco conspícuos em ambas as faces, domácias ausentes. Inflorescência terminal, subséssil a curtamente pedunculada, em cimeira congesta, 6-multiflora; flores sésseis; hipanto turbinado, tubo ausente, lacínios triangular-subulados, apresentando ocasionalmente lobos intercalicinos; corola alva a creme-amarelada, 4,5-5 mm compr., tubo largamente infundibuliforme, externamente glabro, internamente barbado, lobos patentes a reflexos na antese; anteras exsertas na flor brevistila, inclusas na flor longistila. Drupa turbinada, 6-7 mm compr., costada, alva; sementes não observadas.

Material examinado: Santana do Riacho, Serra do Cipó, Mello Barreto 8892, fl. (F, holótipo; SPF isótipo); idem, J.A. Lombardi 3229, 1.X.1999, fl. (BHCB); idem, E. Forero et al. CFSC 7940, 7.IX.1980, fl. (SP); estrada Belo HorizonteConceição do Mato Dentro, km 120, J. Semir \& M. Sazima CFSC 4741, 31.X.1973, fl. (SP, UEC); idem, km 126, A.B. Joly et al. CFSC 4657, 20.X.1973 (E, MBM, SP, UEC); idem, J. Semir \& A.M. Giulietti CFSC 5035, 21.V.1974, fr. (E, SP, UEC); idem, M.S. Silvestre CFSC 9067, 3.XI.1978, fl. (UEC); próximo à estátua do Juquinha, $19^{\circ} 15^{\prime} 13,4^{\prime \prime} \mathrm{S}, 43^{\circ} 33^{\prime} 15,3^{\prime \prime} \mathrm{W}$, M.F. Calió et al. 131, 21.IX.2006, fl. (SPF); Santa Luzia, Serra do Cipó, km 134, Mello Barreto 8892, 4.ll.1938, fr. (UEC); RPPN Brumas do Espinhaço e Ermo do Gerais, F. Fernandes 396, 30.I.2013, fl. (BHZB, SPF).

Rudgea sessilis possui ampla distribuição no sudeste do Brasil (Zappi 2003), porém esta subespécie é endêmica da Serra do Cipó, onde ocorre associada a matas ciliares, florescendo de setembro a janeiro e frutificando em maio. O material F. Fernandes 396 apresenta folhas muito menores do que os restantes, mas as demais características encaixam-se dentro da circunscrição da subespécie.

\subsection{Rudgea viburnoides (Cham.) Benth.,} Linnaea 23: 458. 1850.

Fig. 6. L-M.

Arbusto ou arvoreta, 2-3 $\mathrm{m}$ alt.; ramos castanho-acinzentados, hirsutos quando jovens, entrenós superiores 4-8 cm compr., nós espessados. Estípulas 6-8 x 4-8 mm, com apêndice apical alargado, 7-9-aristado. Folhas pecioladas; pecíolo 4-8 $\mathrm{mm}$ compr.; lâmina amplamente oboval a elíptica ou oblanceolada, base arredondada, margem revoluta, ápice obtuso, por vezes ligeiramente mucronado a apiculado, 7-10 cm compr., 3-8 cm larg., coriácea, adaxialmente bulada, densamente tomentosa na face abaxial; venação broquidódroma, nervuras secundárias e retículo conspícuos em ambas as faces, salientes na face abaxial, domácias ausentes. Inflorescência terminal, em panícula multiflora densa, com eixos pilosos e aplanados; flores sésseis; hipanto turbinado, tubo ausente, lacínios ovais, ciliados; corola alva a creme-amarelada, 8-9 $\mathrm{mm}$ compr., tubo infundibuliforme, externamente piloso, internamente barbado, lobos reflexos na antese, anteras exsertas na flor brevistila, inclusas na flor longistila. Drupa ovoide, 9-11 mm compr., lisa, amarela a vermelho-alaranjada; sementes hemisféricas, $7 \mathrm{~mm}$ compr., vermelhoescuras a atrovináceas.

Material examinado: Santana do Riacho, Mãe D'Água, F.R. Salimena-Pires et al. CFSC 10803, 9.X.1987, fl. (SPF, SPFR); 19-18'11"S, 4336'03"W, J.R Pirani et al. 4208, 4.III.1998, fr. (SPF, SPFR); Morro da Pedreira, 1920'S, 4340'W, J.R. Pirani et al. 3666, 2.IV.1996, fr. (K, SPF); Estrada da Usina, B. Stannard et al. CFCR 6003, 15.XI.1984, fl. (K, SPF); Usina Coronel Américo Teixeira, D.C. Zappi 849 25.VIII.2007, fr. (ESA, SPF); rodovia Belo Horizonte Conceição do Mato Dentro, km 104, Morro do Calcário, R.M. Harley et al. CFCR 5903, 13.XI.1984, fl. (SPF); idem, km 114, J. Diacui \& G. Esteves CFSC 9136, 18.VII.1983, fr. (SPF, SPFR); Parque Nacional da Serra do Cipó, descida para as Bandeirinhas, A.M. Giulietti et al. CFSC 12646, 28.VII.1991, fr. (SPF). "Pirapama", L. Krieger \& Urbano [Câmara] 8793, 13.VII.1970, fr. (CESJ, K).

Material adicional: Minas Gerais: Joaquim Felício, Serra do Cabral, Davis et al. 2467, VII.1976, fl. (E, L, UEC).

Rudgea viburnoides encontra-se amplamente distribuída em cerrados e matas ciliares do Brasil central, atingindo a Bahia e o Amazonas, Paraguai, Bolívia, Peru e Equador (Zappi 2003). Na Serra do Cipó, foi coletada no afloramento de calcário na base da Serra, e também em matas deciduais na face oeste da Serra (Usina Cel. Américo Teixeira). 


\section{Sabicea Aubl.}

Lianas herbáceas, arbustos ou subarbustos escandentes ou eretos, geralmente pubescentes; ramos cilíndricos ou tetragonais, volúveis, usualmente pubescentes. Estípulas interpeciolares eretas ou recurvadas, triangulares, ovais a obovado-espatuladas ou liguladas, geralmente persistentes. Folhas opostas, sésseis a pecioladas. Inflorescências axilares, sésseis ou pedunculadas, corimbosas, glomerulares ou capitadas; flores bissexuadas, actinomorfas, geralmente 5-meras, sésseis ou pediceladas, heterostílicas; lacínios 3-5, curtamente denticulados; corola com prefloração valvar, 4-5-mera, infundibuliforme ou hipocrateriforme; estames 4-5, inseridos na porção mediana do tubo da corola; ovário 3-5-carpelar, 3-5-locular, lóculos pluriovulados; estigma 3-5-partido. Fruto bacáceo, globoso; sementes numerosas, diminutas, ovais ou anguladas, reticuladas a foveoladas.

33.1. Sabicea brasiliensis Wernh. Monogr. Sabicea 51, pl. 12. 1914.

Nome vulgar: sangue-de-cristo.

Fig. 5. M.

Arbusto com ramos eretos ou trepadores, 0,4-1 $\mathrm{m}$ alt.; ramos acinzentados, alvo-lanosos quando jovens, cilíndricos, entrenós distais 2-3 cm compr. Estípulas largamente triangulares a obovadoespatuladas, 4-5 × 5-8 mm. Folhas sésseis a curtamente pecioladas; pecíolo 0-4 mm compr.; lâmina oval a amplamente lanceolada, base arredondada, raramente aguda, margem plana, ápice obtuso, por vezes acutiúsculo ou levemente mucronado, (4-)6-9 cm compr., (2-)3-5 cm larg., cartácea, discolor, secando mais clara na face abaxial, bulada e velutina na face adaxial, densamente alvo-lanosa a panosa na face abaxial; venação broquidódroma, nervuras secundárias em 12-16 pares, salientes na face abaxial. Inflorescências fasciculadas, 6-12-floras, protegidas por brácteas foliáceas; flores sésseis; hipanto turbinado, densamente lanoso externamente, tubo presente, lacínios triangulares, agudos; corola alva a creme-amarelada, 6-8 x 4-5 mm, tubo cilíndrico, externamente tomentoso, internamente glabro, lobos patentes na antese. Baga ovoide, $6 \mathrm{~mm}$ compr., densamente lanosa, vinácea a atrovinácea quando madura; sementes tetraédricas, 0,5-0,7 mm compr., castanho-avermelhadas.

Material examinado: Congonhas do Norte, estrada para Gouveia, ca. $10 \mathrm{~km} \mathrm{~N}$ de Congonhas do Norte, 1846'10"S, 4344'45"W, J.R. Pirani et al. 5785, 5.II.2009, fl. (SPF). Jaboticatubas, Serra do Cipó,rodovia Lagoa Santa Conceição do Mato Dentro - Diamantina, km 112, A.B. Joly et al. CFSC 1014, 5.III.1972, fr. (SP, UEC); idem, km 112-5, A.B. Joly et al. CFSC 1448, 15.IV.1972, fr. (SP, UEC); idem, km 110, M. Sazima \& J. Semir CFSC 3847, 16-24.II.1973, fl. (SP); along road from village of Almeida to city of Conceição do Mato Dentro, at km 111, just north of Chápeu do Sol" hotel, G. Eiten \& L.T. Eiten 10908, 10.III.1969, fl. (SP). Santana de Pirapama, Serra do Cipó, estrada Santana do
Pirapama - Santana do Riacho, trecho de São José da Cachoeira - Inhame, subida da trilha da Senhorinha, $19^{\circ} 00^{\prime 22} "$ S, 4345'20"W, V.C. Souza et al. 32739, 19.II.2007, fl. (ESA, K, SPF); acesso pela Faz. Inhame, E.S. Cândido et al. 526, 20.III.2011, fr. (SPF); Cachoeira do Quartel, 18058'44" S, 4346'31" W, D.C. Zappi et al. 1731, 5.III.2009, fl. (K, RB, SPF); Capela de São José, Terreno do Sr. Luiz, perto do Rio das Pedras, 1900'18" S, 4346'34" W, D.C. Zappi et al. 2769, 9.III.2010, fl., fr. (K, RB, SPF). Santana do Riacho, Parque Nacional da Serra do Cipó, E.A. Anunciação 206 , 1.V.1993, fl. (SP); Mãe D'água (Vale do córrego Véu da Noiva), L. Rossi et al. CFSC 6996, 12.I.1981, fl. (SP); Estrada da Usina, km 2, M.G.L. Wanderley et al. 598, 21.III.1983, fl. (SP); rodovia Belo-Horizonte - Conceição do Mato Dentro, km 104, J.R. Pirani et al. CFSC 9785-A, 30.IV.1986, fr. (SPF); idem, km 105, A. Conceição et al. CFSC 13903, 5.IV.1995, fl. (SPF); idem, km 106, D.C. Zappi \& F.A. Vitta CFSC 9995, 2.Il.1987, fl. (SPF); idem, km 106, 1917'S, 4336'W, G.M. Faria \& M. Mazucato 26, II.1990, fl. (SPF); idem, km 112 , H.S. Irwin et al. 20439, 18.ll.1968 (MO, UB); caminho da base do IBAMA (R. Cipó) para o Capão dos Palmitos, J.R. Pirani et al. CFSC 11976, 25.III.1991, fr. (SPF); Alto Congonhas, $12 \mathrm{~km}$ NE Cardeal Mota, 1920'S, 4335'W, M.M. Arbo et al. 4718, 9.Il.1991, fl., fr. (CTES, SPF); Serra do Cipó, acesso pela Faz. Inhame, trilha do João Carrinho, após o Rio das Pedras, D.C. Zappi et al. 807, 18.II.2007, fl. (ESA, SPF).

Material adicional: Minas Gerais: São José de Almeida, $7 \mathrm{~km}$ NE da cidade no caminho para Conceição do Mato Dentro, 1926'S, 4348'W, M.M. Arbo et al. 4779, 10.II.1991, fr. (CTES, SPF).

Sabicea brasiliensis ocorre nos cerrados do Brasil e da Bolívia, com registros nos estados do Mato Grosso, Mato Grosso do Sul, Tocantins, Goiás, Distrito Federal, Bahia e Minas Gerais (Barbosa et al. 2014). $\mathrm{Na}$ Serra do Cipó, foi coletada no cerrado, campo cerrado e em floresta semidecidual, florescendo e frutificando entre janeiro e maio.

\section{Schizocalyx Wedd.}

Árvores ou arvoretas; ramos cilíndricos, glabros ou tomentosos. Estípulas interpeciolares totalmente conatas, triangulares, decíduas. Folhas opostas, esparsamente pilosas. Inflorescências multiforas, em panículas laxas terminais ou subterminais; flores bissexuadas, actinomorfas, 5meras, alvas, lacínios truncados a denteados; corola com prefloração imbricada, rotácea, glabra ou levemente pilosa na parte inferior do tubo; estames 5, dimórficos, exsertos, inseridos na base do tubo; ovário bilocular, lóculos pluriovulados; estigma bífido. Cápsulas loculicidas, abrindo-se no ápice, globosas a alongadas, pilosas; sementes numerosas, tetraédricas, diminutas.

34.1. Schizocalyx cuspidatus (A.St.-Hil.) Kainul. \& B.Bremer, Amer. J. Bot. 97: 1976. 2010.

Bathysa cuspidata (A.St.-Hil.) Hook.f. ex K.Schum. in Mart., Eichler \& Urb., FI. bras. 6(6): 237. 1889.

Fig. 3. G.

Árvores ou arvoretas 2-6 m alt.; râmulos cilíndricos, castanhos, seríceos a glabrescentes. 
Estípulas estreitamente triangulares, $15-20 \mathrm{~mm}$ compr., 3-5 mm larg., com carena não evidente. Folhas pecioladas; pecíolo $10-15 \mathrm{~mm}$ compr., ligeiramente sulcado; lâmina lanceolada a elíptica, base cuneada, margem plana, ápice agudo, acuminado a aristado, 20-35(-40) cm compr., 11-13(19) cm larg., membranácea, discolor, ambas as faces velutinas; venação broqidódroma, nervuras salientes e retículo pouco conspícuo na face abaxial, nervuras impressas e retículo indistinto na face adaxial, domácias ausentes. Panículas laxas, multifloras terminais e subterminais (até o segundo nó); pedúnculo 10-15 cm compr., delicado; brácteas inconspícuas; botões florais obtusos; cálice $3 \mathrm{~mm}$ compr., seríceo, tubo denteado no ápice; corola 4-6 $\mathrm{mm}$ compr., alva, tubo longo, lobos fortemente reflexos, ca. 3-4 $\mathrm{mm}$ compr.; estames exsertos e eretos, anteras ca. $5 \mathrm{~mm}$ compr.; estilete exserto, até $6 \mathrm{~mm}$ compr., hirsuto, estigma bilobado com ramos divergentes. Cápsulas (imaturas) 4-5 mm compr., turbinadas, subsésseis, epicarpo seríceo; sementes $0,5 \mathrm{~mm}$ compr.

Material examinado: Itambé do Mato Dentro, distrito de Santana do Rio Preto (Cabeça de Boi), APA do Parque Nacional da Serra do Cipó, M.F. Santos \& J.B.C. Marques 382, 22.X.2008, fr. (BHCB, SPF). Santana do Riacho, Serra do Cipó, antiga estrada, A.E. Luchi et al. 351, 7.XI. 1995, estéril (SP, SPF).

Material adicional: Minas Gerais: Caparaó, encosta da Serra do Caparaó, abaixo do Parque Nacional, J.R. Pirani et al. 2558, 24.X.1989, fr. (SPF); Caratinga, Estação Biológica de Caratinga, P.M. Andrade \& M.A. Lopes 729 , 22.III.1986, fl. (SPF); Timóteo, Macuco, Parque Estadual do Rio Doce, 1935'28"S, 4234'07"W, G.S. França \& F. Raggi 496, 3.III.2004, fl. (SPF). São Paulo: São José do Barreiro, Fazenda Atibaia, acesso pelo km 258 da Rodovia dos Tropeiros (SP 068), 22ํ38'34"S, 44ํ39'24"W, H. Serafim \& M.F. Santos 329, 21.III.2007 (RB, SPF).

Espécie endêmica do leste do Brasil (Barbosa et al. 2014), ocorrendo em ambientes florestais na Serra do Cipó, com frutos em outubro. Inicialmente incluídas dentro de Bathysa, as espécies de Schizocalyx possuem ramos cilíndricos, estípulas conatas e decíduas e inflorescências laxas, enquanto que Bathysa tem ramos quadrangulares, estípulas persistentes conatas apenas na base e inflorescências densas.

\section{Simira Aubl.}

Árvores ou arvoretas, raramente arbustos; ramos cilíndricos, glabros ou pilosos. Estípulas interpeciolares concentradas na porção distal dos ramos, estreitamente triangulares, livres, decíduas, glabras ou pilosas. Folhas verticiladas, raramente opostas, glabras ou pilosas, multinervadas, frequentemente liradas, subcordadas ou arredondadas na base. Inflorescências axilares ou subterminais, racemosas, por vezes reduzidas e dicasiais, longamente pedunculadas, multifloras. Flores bissexuadas, actinomorfas, 5-meras, homostílicas, sésseis ou curtamente pediceladas, subtendidas por brácteas e bractéolas triangulares; hipanto longamente campanulado, apicalmente truncado ou denteado, irregularmente 5-lobado, lobos ausentes no fruto; corola com prefloração valvar, hipocrateriforme a ligeiramente infundibuliforme, alva ou creme, com fauce amarelada ou esverdeada; tubo da corola de extensão semelhante à do hipanto, lobos patentes a fortemente reflexos; estames 5 , inseridos na fauce da corola, longamente exsertos; ovário bicarpelar, bilocular, lóculos pluriovulados, disco nectarífero presente, estilete glabro ou piloso, estigma bífido. Fruto capsular, globoso a elíptico ou subcilíndrico, restos do cálice decíduos deixando apenas uma cicatriz apical, exocarpo geralmente lenhoso e lenticelado, abrindo-se por pressão exercida pelo endocarpo elástico, replo rígido; sementes numerosas, semilunares, planas, apicalmente aladas.

35.1. Simira sampaioana (Standl.) Steyerm. Mem. New York Bot. Gard. 23: 307. 1972.

Fig. 3. H-I.

Arvoreta $6 \mathrm{~m}$ alt.; ramos cilíndricos, glabros, castanho-claros, levemente estriados. Estípulas estreito-triangulares, 5-8 mm compr., 1,5-2,5 mm larg., pilosas adaxialmente. Folhas verticiladas, pecioladas; pecíolo 0,3-0,8 cm compr., 0,1-0,15 cm larg.; lâmina elíptica a largamente elíptica a obovada, base subcordada a truncada, margem plana, ápice atenuado a agudo, 7-13 cm compr., 3-6,5 cm larg., cartácea, ambas as faces verde oliváceas quando secas, jovem pubescente abaxialmente, adulta totalmente glabra; venação broquidódroma, nervuras secundárias 13-17 pares, salientes na face abaxial, retículo paralelo, evidente. Inflorescência 10-25-flora, cimosa, pedúnculo minutamente pubescente, $2-5 \mathrm{~cm}$ compr.; flores aromáticas, pediceladas; hipanto verde, campanulado, seríceo-pubescente, 0,4-0,5 cm compr., 2-2,5 mm larg., truncado ou denteado; corola creme, hipocrateriforme, externamente curtamente serícea, fauce barbada, 6-7 mm compr., 5-6 mm larg., lobos oblongos com ápice arredondado, ligeiramente estreitado e corniculado, $4 \mathrm{~mm}$ compr., $2 \mathrm{~mm}$ larg.; filetes 1-2 mm compr., anteras 5-6 mm compr.; estilete 4-5 mm compr., estigma bífido, lobos espessados apicalmente, 3-3,5 mm compr. Cápsula globosa, rígida, lenticelada, 2-3,5 cm diâm, endocarpo flexível, castanho-amarelado, replo estriado, castanho; sementes semilunares, 10-21 mm compr., com uma metade ocupada pelo núcleo seminífero espessado e a outra ala metade formando uma ala delgada e transparente.

Material examinado: Santana de Pirapama, Serra do Cipó, Fazenda Toucan Cipó, perto dos estábulos, 19000'18"S, 4346'34"W, D.C. Zappi et al. 2753, 7.III.2010, estéril (K, SPF).

Material adicional: São Paulo: Carioba, Fazenda Salto Grande à margem do Rio Piracicaba, M. Kuhlmann 
2793, 28.XII.1951, fl. (SP, SPF); Tietê, Estação Experimental do IAC, L.C. Bernacci et al. 1553, 26.IV.1995, fr. (IAC, SPF); Cardoso, antigo Porto Militão, L.C. Bernacci et al. 1824, 18.V.1995, fr. (IAC, SPF); Paulo de Farias, Estação Ecológica, J.Y. Tamashiro et al. T 268, 18.VI.1994, fr. (SPF, UEC).

Simira sampaioana é uma espécie amplamente distribuída nos cerrados brasileiros, ocorrendo também no Paraguai e Nordeste da Argentina; no Brasil, ocorre em Minas Gerais, São Paulo e Paraná (Barbosa et al. 2014). Na Serra do Cipó, foi coletada apenas uma vez, em floresta semidecidual, estéril. Caracteriza-se pelas folhas congestas na porção distal dos ramos e pelos frutos capsulares com muitas sementes aladas.

\section{Tocoyena Aubl.}

Árvores, arvoretas ou arbustos; ramos cilíndricos, glabros, estrigosos ou tomentosos, fistulosos ou não. Estípulas interpeciolares deltoides a triangulares, livres ou conatas, persistentes ou decíduas, glabras ou pilosas. Folhas opostas, glabras ou pilosas. Inflorescências terminais ou subterminais, corimbosas, cimosas, por vezes reduzidas e dicasioides, curto-pedunculadas, multifloras. Flores bissexuadas, ligeiramente zigomorfas, 5-meras, sésseis, homostílicas; hipanto campanulado, truncado, 5-lobado, persistente no fruto, glabro ou indumentado; corola com prefloração contorcida, hipocrateriforme a ligeiramente infundibuliforme, alva, creme, amarelada ou esverdeada; tubo floral estreito e muito desenvolvido, lobos patentes; estames 4-6, sésseis ou subsésseis, inseridos na fauce da corola, exsertos; ovário bicarpelar, bilocular, lóculos pluriovulados, disco nectarífero presente; estilete glabro ou piloso, estigma bífido. Fruto bacáceo, globoso, com restos do cálice proeminentes; sementes numerosas, achatadas, envolvidas numa polpa gelatinosa.

36.1. Tocoyena formosa (Cham. \& Schltdl.) K.Schum. in Mart., Eichler \& Urb., FI. bras. 6(6): 347. 1889.

Fig. 1. J-K.

Arbusto ou arvoreta 2-4,5 m alt.; ramos cilíndricos, estrigosos a tomentosos, glabrescentes quando velhos. Estípulas decíduas, deltadas a estreito-triangulares, 3-7 mm compr., 2,5-5 mm larg., estrigosas. Folhas pecioladas; pecíolo $0,8-2,0 \mathrm{~cm}$ compr., 0,3-0,5 cm larg.; lâmina elíptica a largamente elíptica, ovada, obovada a largamente obovada, base cuneada a atenuada, margem plana a ondulada, ápice obtuso a arredondado ou agudo, raramente mucronado, 12-22 cm compr., 6-12 cm larg., cartácea a coriácea, face adaxial secando enegrecida, glabrescente com nervuras estrigosas a esparsamente estrigosas, face abaxial geralmente verde-olivácea, levemente ferrugínea, densamente tomentosa ou com tricomas restritos às nervuras; venação broquidódroma, nervuras salientes na face abaxial. Inflorescência 10-20-flora, subséssil, cimosa. Flores aromáticas; hipanto verde, campanulado, tomentoso a glabrescente, 1-1,5 cm compr., 0,35-0,5 mm larg., lacínios triangulares a estreitamente triangulares, ápice agudo, $1 \mathrm{~mm}$ compr., 0,3 $\mathrm{mm}$ larg.; corola creme-esverdeada na antese, passando a amarelada, pubérula a tomentosa, hipocrateriforme, 9-13 cm compr., 2-3 mm larg. na base, lobos elípticos a obovados, ápice arredondado, $15 \mathrm{~mm}$ compr., $10 \mathrm{~mm}$ larg.; filetes 2-4 mm compr., anteras creme, $6-8 \mathrm{~mm}$ compr.; estilete 9-15 mm compr., estigma esverdeado, 6-8 mm compr. Baga verde, coriácea, rugosa, esparsamente estrigosa a glabra, largamente ovoide, largamente elipsoide ou esférica, 4-4,5 cm compr., 33,5 cm larg.; sementes 5-6 mm compr.

Material examinado: Jaboticatubas, Serra do Cipó, estrada para a sede do IBAMA, J.R. Pirani et al. CFSC 12805, 6.XII.1991, fl. (SPF); idem, F.A. Vitta 314, VI.1996, fr. (UEC). Santana de Pirapama, Serra do Cipó, Fazenda Toucan Cipó, perto dos estábulos, 1900'19,2"S, 4346'22,5"W, D.C. Zappi et al. 2456, 20.XI.2009, fl. (K, RB, SPF). Santana do Riacho, Serra do Cipó, ca. $1 \mathrm{~km}$ da base do IBAMA, próximo da Cachoeira Grande no Rio Cipó, J.R. Pirani et al. CFSC 11897, 24.III.1991, fr. (SPF); rodovia Belo Horizonte - Conceição do Mato Dentro, km 104, A. FreireFierro \& F.R.S. Pires 1549, 23.XI.1990, fl. (SPF); estrada Santana do Riacho - Lapinha, encosta oeste da Serra do Cipó, 190', 4342'W, A. Rapini et al. 593, 4.III.1998, fr. (SPF); Cardeal Mota, sede da Fazenda Monjolos, L.S. Kinoshita \& L. Yamamoto 03/212, 6.XII.2003, fl. (UEC); em frente à Pousada Fazenda Monjolos, L.S. Kinoshita et al. C016, 24.IX.2002, fl. (UEC).

Material adicional: Minas Gerais: Cristália, estrada Cristália-Botumirim, $25 \mathrm{~km}$ de Crisitália, R.S. Oliveira et al. 81, 1.XII.2004, fl. (SPF); Diamantina, próximo ao antigo leito da estrada de ferro, próximo a Guinda, $R$. Mello-Silva et al. CFCR 11752, 9.I.1988, fr. (SPF); Grão-Mogol, bacia do córrego Escurona, 1635'42"S, 4257'48"W, 750-800 m, R. Mello-Silva et al. CFCR 11354, 2.XI.1987, fl. (K, MBM, SPF); Joaquim Felício, Serra do Cabral, A.M. Giulietti et al. CFCR 6404, 23. XI.1984, fl. (SPF).

Tocoyena formosa é uma espécie de ampla distribuição, ocorrendo do Suriname ao Paraguai; no Brasil, ocorre da Região Norte ao Paraná (Barbosa et al. 2014). Na Serra do Cipó, é encontrada em cerrado e campo-cerrado, tendo sido coletada com flores entre setembro e dezembro e com frutos em março e junho. Caracteriza-se pela flor longo-tubulosa, de antese noturna e bagas agrupadas no ápice dos ramos.

\section{Agradecimentos}

Agradecemos ao CNPq pela bolsa de Iniciação Científica concedida à M.F. Calió, pelo apoio ao projeto florístico da Serra do Cipó, pela bolsa de Produtividade em Pesquisa concedida a J.R. Pirani e pela Licença de Coleta EXC020/80, que possibilitou a ampliação da amostragem na porção noroeste da área através do Projeto Toucan Cipó (Univ. S. Paulo/RBG, 
Flora da Serra do Cipó, Minas Gerais: Rubiaceae

Kew); ao IBAMA pelo apoio logístico durante o trabalho de campo no Parque Nacional da Serra do Cipó; aos curadores dos herbários RB, UEC e SP pela disponibilização dos seus acervos; ao ilustrador Klei Souza pela cobertura das ilustrações em nanquim.

\section{Referências}

ANDERSSON, L. 1992. A provisional checklist of Neotropical Rubiaceae. Scripta Botanica Belgica 1: 1-200.

BACIGALUPO, N.M. \& CABRAL, E.L. 1996. Infrageneric classification of Borreria (Rubiaceae - Spermacoceae) on the basis of American species. Opera Botanica Belgica 7: 297-308.

BACIGALUPO, N.M. \& CABRAL, E.L. 2006. Nuevas combinaciones en el género Diodella (Rubiaceae Spermacoceae). Darwininana 44(1): 98-104.

BACIGALUPO, N.M. \& CABRAL, E.L. 2007a. Borreria. In M.G.L. WANDERLEY, G.T. SHEPHERD, T.S. MELHEM \& A.M. GIULIETTI (eds.) Flora Fanerogâmica do Estado de São Paulo 5: 276-285.

BACIGALUPO, N.M. \& CABRAL, E.L. 2007b. Diodella. In: M.G.L. WANDERLEY, G.T. SHEPHERD, T.S. MELHEM \& A.M. GIULIETTI (eds.) Flora Fanerogâmica do Estado de São Paulo 5: 313-315.

BARBOSA, M.R.V., ZAPPI, D.C., TAYLOR, C., CABRAL, E., JARDIM J.G., PEREIRA. M.S., CALIÓ, M.F., PESSOA, M.C.R., SALAS, R., SOUZA, E.B., DI MAIO, F.R., MACIAS, L., ANUNCIAÇÃO, E.A., GERMANO FILHO, P. 2010. Rubiaceae. In: R.C. FORZZA et al. (Org.) Catálogo de Plantas e Fungos do Brasil. Rio de Janeiro: Jardim Botânico do Rio de Janeiro, v. 2, p. 1545-1591.

BARBOSA, M.R.V., ZAPPI, D.C., TAYLOR, C., CABRAL, E., JARDIM J.G., PEREIRA. M.S., CALIÓ, M.F., PESSOA, M.C.R., SALAS, R., SOUZA, E.B., DI MAIO, F.R., MACIAS, L., ANUNCIAÇÃO, E.A., GERMANO FILHO, P. OLIVEIRA, J.A., BRUNIERA, C.P., GOMES, M.,TONI, K. 2014. Rubiaceae. In: Lista de Espécies da Flora do Brasil. Jardim Botânico do Rio de Janeiro. (http://floradobrasil.jbrj.gov.br/jabot/floradobrasil/FB210)

CABRAL, E.L. 1991. Rehabilitacióm del género Galianthe (Rubiaceae). Bol. Soc. Argent. Bot. 27(3-4): 235-249.

CABRAL, E.L. 1996. Novedades en Galianthe (Rubiaceae). Bonplandia 7(1-4): 1-30.

CABRAL, E.L. \& BACIGALUPO, N.M. 1997a. Nuevas espécies de Borreria. Acta Bot. Brasilica 11: 45-50.

CABRAL, E.L. \& BACIGALUPO, N.M. 1997b. Revisión del género Galianthe subg. Ebelia stat. nov. (Rubiaceae: Spermacoceae). Ann. Missouri Bot. Gard. 84(4): 857-877.

CABRAL, E.L. \& BACIGALUPO, N.M. 2000. Novedades taxonómicas en Galianthe y Borreria (Rubiaceae Spermacoceae). Bonplandia 10(1-4): 119-128.
CABRAL, E.L. \& Miguel, L.M. \& SALAS, R.M. 2011. Dos especies nuevas de Borreria (Rubiaceae), sinopis y clave de identificación. Acta Botanica Brasilica 25(2): 255-276.

CAMPOS, M.T.V.A., ZAPPI, D.C., CALIÓ, M.F. \& PIRANI, J.R. 2006. Flora de Grão Mogol III: Rubiaceae. Boletim de Botânica da Univ. São Paulo 24: 41-68.

COSTA, C.B. 2004. Revisão taxonômica de Coccocypselum P.Br. (Rubiaceae). Tese de Doutorado, Instituto de Biociências, São Paulo.

DELPRETE, P.G. \& CORTÉS-B., R. "2006" [2007]. A synopsis of the Rubiaceae of the states of Mato Grosso and Mato Grosso do Sul, central-western Brazil, with a key to genera, and a preliminary species list. Revista de Biologia Neotropical 3: 13-96.

DELPRETE, P.G. \& KIRKBRIDE Jr., J.H. 2008. Clarification of Borreria gymnocephala, Diodia gymnocephala, Diodia schumannii, Borreria flavovirens and Spermacoce schumannii (Rubiaceae). Journal of the Botanical Research Institute of Texas 2(1): 305-308.

DELPRETE, P.G., SMITH, L.B. \& KLEIN, R.M. 2005. Rubiáceas. In: A. Reis (ed.). Flora llustrada Catarinense RUBI II: 349-842.

DI MAIO, F.R. 1996 (publ. 1998). Revisão taxonômica do gênero Hindsia Bentham (Rubiaceae, Hedyotideae). Arquivos do Jardim Botânico do Rio de Janeiro 34(1): 51-92.

GIULIETTI, A.M., MENEZES, N.L., PIRANI, J.R., MEGURO, M. \& WANDERLEY, M.G.L. 1987. Flora da Serra do Cipó, Minas Gerais: caracterização e lista das espécies. Bol. Bot. Univ. São Paulo 9: 1-151.

GOVAERTS, R. 2013. World Checklist of Rubiaceae. The Board of Trustees of the Royal Botanic Gardens, Kew. Published on the Internet; http://www.kew.org/wcsp/ accessed 26 August 2013; 08:50 GMT.

GROENINCKX, I., DESSEIN, S., OCHOTERENA, H., PERSSON, C., MOTLEY, T.J., KAREHED, J., BREMER, B., HUYSMANS, S. \& SMETS, E. 2009. Phylogeny of the Herbaceous Tribe Spermacoceae (Rubiaceae) Based on Plastid DNA Data. Annals of the Missouri Botanical Garden 96(1):109-132.

IUCN (2001). IUCN Red List Categories. Prepared by the IUCN Species Survival Comission. IUCN, Gland, Switzerland and Cambridge, U.K.

JUNG-MENDAÇOLLI, S. (coord.) 2007. Rubiaceae in M.G.L. WANDERLEY, G.T. SHEPHERD, T.S. MELHEM \& A.M. GIULIETTI (eds.) Flora Fanerogâmica do Estado de São Paulo 5: 259-460.

KIRKIBRIDE Jr., J.H. 1976. A revision of the genus Declieuxia (Rubiaceae). Mem. New. York. Bot. Gard. 28 (4): 1-87.

KIRKIBRIDE Jr., J.H. 1979. A revision of the genus Psyllocarpus (Rubiaceae). Smithsonian Contr. Bot. 41: 1-32.

MÜLLER ARGOVIENSIS, J. 1881. Rubiaceae in In C.F.P. Martius, A.G. Eichler \& I. Urban (eds.). Flora Brasiliensis 6(5): 1-485. 
SCHUMANN, K. 1888. Rubiaceae. In C.F.P. Martius, A.G. Eichler \& I. Urban (eds.). Flora Brasiliensis 6(6): 1-124.

SCHUMANN, K. 1889. Rubiaceae. In C.F.P. Martius, A.G. Eichler \& I. Urban (eds.). Flora Brasiliensis 6(6): 125-466.

STEYERMARK, J. 1972. Rubiaceae. In: B. Maguire (ed.), The Botany of the Guayana Highland 9. Mem. New York Bot. Gard. 23: 227-832.

STEYERMARK, J. \& KIRKIBRIDE Jr., J.H. 1977. Review of the Genus Perama (Rubiaceae). Brittonia 29: 191-198.

TAYLOR, C.M. 2007. Psychotria. In: M.G.L. WANDERLEY, G.T. SHEPHERD, T.S. MELHEM \& A.M. GIULIETTI (eds.) Flora Fanerogâmica do Estado de São Paulo 5: 389-412.

TAYLOR, C.M., CAMPOS, M.T.V.A., ZAPPI, D.C. 2007. Flora da Reserva Ducke, Amazonas, Brasil: Rubiaceae. Rodriguesia 58: 549-616.

ZAPPI, D.C. 2003. Revision of Rudgea (Rubiaceae) in Southeastern and Southern Brazil. Kew Bull. 58(3): 513-596.
ZAPPI, D.C., BARBOSA, M.R.V., CALIÓ. M.F., JARDIM, J.G., PEREIRA, M.S., SOUZA, E.B. 2009. Rubiaceae. In: STEHMANN, J.R., FORZZA, R.C., SALINO, A., SOBRAL, M., da COSTA, D.P., KAMINO, L.H.Y. (org.) Plantas da Floresta Atlântica. Rio de Janeiro: Instituto de Pesquisas Jardim Botânico do Rio de Janeiro, p. 449-461.

ZAPPI, D.C., SASAKI, D., MILLIKEN, W., PIVA, J.H., HENICKA, G.S., BIGGS, N., FRISBY, S. 2011. Plantas vasculares da região do Parque Estadual Cristalino, norte de Mato Grosso, Brasil. Acta Amazonica 41: 29-38,

ZAPPI, D.C. 2007. Genipa. In: M.G.L. WANDERLEY, G.T SHEPHERD, T.S. MELHEM \& A.M. GIULIETTI (eds.) Flora Fanerogâmica do Estado de São Paulo 5: 344-345.

ZAPPI, D.C. \& NUNES, T.S. 2002. Lista preliminar da Família Rubiaceae na Região Nordeste do Brasil. 1. ed. Richmond: Royal Botanic Gardens, Kew, v. 1., 50 p .

ZAPPI, D.C. \& STANNARD, B.L. 1995. Rubiaceae. In B.L. STANNARD (ed.) Flora of the Pico das Almas, Royal Botanic Gardens, Kew, p. 546-578. 